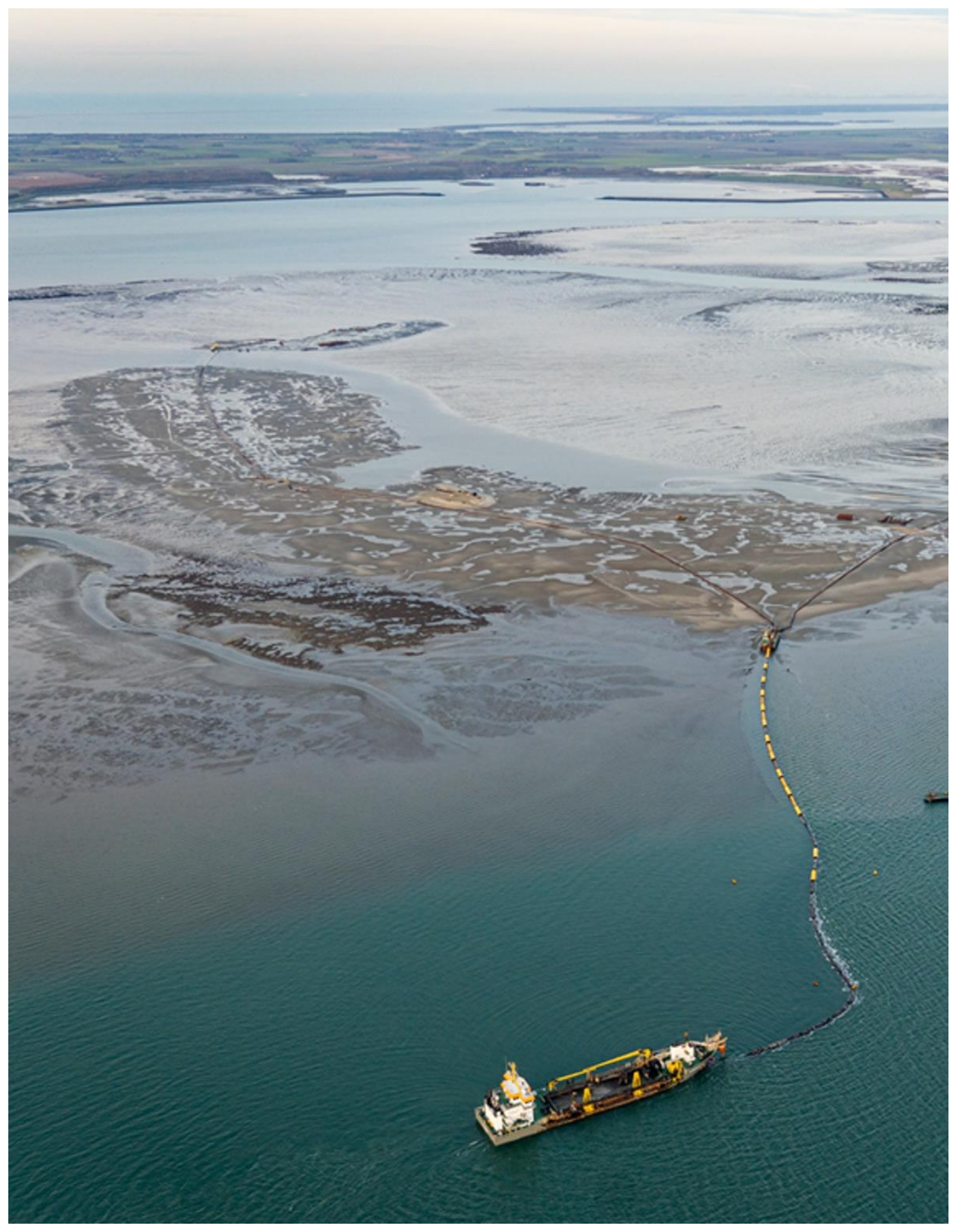

\title{
Roggenplaatsuppletie (Oosterschelde): ontwikkelingen voor (T0: 2015 - 2019) en het eerste jaar na aanleg (T1: 2020) van de suppleties
}

Auteur(s): Brenda Walles, Susanne van Donk, Alicia Hamer, Jeroen Wijsman, Tom Ysebaert, Eugene Rurangwa, Lodewijk de Vet, Jebbe van der Werf, Jeroen van Dalen, Tjeerd Bouma, Arno Slager
Wageningen University \&

Research rapport C038/21 


\section{Roggenplaatsuppletie (Oosterschelde): ontwikkelingen voor (T0: 2015 - 2019) en het eerste jaar na aanleg (T1: 2020) van de suppleties}

Auteur(s): $\quad$ Brenda Walles, Susanne van Donk, Alicia Hamer, Jeroen Wijsman, Tom Ysebaert, Eugene Rurangwa, Lodewijk de Vet, Jebbe van der Werf, Jeroen van Dalen, Tjeerd Bouma, Arno Slager

Wageningen Marine Research

Deltares

Rijkswaterstaat

NIOZ 
Keywords: Oosterschelde, Roggenplaat, suppletie, monitoring, morfologie, ecologie, bodemdieren, steltlopers, schelpdieren, mosselpercelen

\author{
Opdrachtgever: Rijkswaterstaat Zee \& Delta \\ T.a.v.: Eric van Zanten \\ 3500 GE Utrecht
}

Dit rapport is gratis te downloaden van https://doi.org/10.18174/544639

Wageningen Marine Research verstrekt geen gedrukte exemplaren van rapporten.

Wageningen Marine Research is ISO 9001:2015 gecertificeerd.

Foto omslag: Edwin Paree

\title{
(C) Wageningen Marine Research
}

\footnotetext{
Wageningen Marine Research, instituutWageningen Marine Research aanvaardt geen aansprakelijkheid voor gevolgschade, binnen de rechtspersoon Stichtingnoch voor schade welke voortvloeit uit toepassingen van de resultaten van Wageningen Research, hierbijwerkzaamheden of andere gegevens verkregen van Wageningen Marine Research. vertegenwoordigd door Opdrachtgever vrijwaart Wageningen Marine Research van aanspraken van derden Dr.ir. J.T. Dijkman, Managing director in verband met deze toepassing.

KvK nr. 09098104, Alle rechten voorbehouden. Niets uit deze uitgave mag weergegeven en/of WMR BTW nr. NL 8113.83.696.B16. gepubliceerd worden, gefotokopieerd of op enige andere manier gebruikt worden zonder schriftelijke toestemming van de uitgever of auteur.
} Code BIC/SWIFT address: RABONL2U

A_4_3_1 V31 (2021) 


\section{Inhoud}

$\begin{array}{ll}\text { Samenvatting } & 5\end{array}$

$1 \quad$ Inleiding 9

1.1 Achtergrond 9

1.1.1 Zandhonger 9

$\begin{array}{lr}1.1 .2 \text { Suppleties } & 9\end{array}$

$\begin{array}{llr}1.2 & \text { Project Roggenplaatsuppletie } & 10\end{array}$

$2 \quad$ Rolverdeling en verantwoording 12

$\begin{array}{lll}3 & \text { Leeswijzer } & 13\end{array}$

$4 \quad$ Aanleg suppletie $\quad 15$

4.1 Proeven optimalisatie ecologisch herstel suppletie 17

5 T0 en T1 monitoring: een overzicht van de uitgevoerde metingen en $\begin{array}{ll}\text { activiteiten } & \mathbf{2 1}\end{array}$

6 Recente morfologische en ecologische toestand en ontwikkeling van de

Roggenplaat (TO en T1) 22

$\begin{array}{lll}6.1 & \text { Doel } & 22\end{array}$

6.2 Morfologische ontwikkelingen $\quad 22$

6.2.1 Recente hoogteontwikkeling Roggenplaat $\quad 22$

$\begin{array}{ll}\text { 6.2.2 Ontwikkeling suppletie-elementen } & 29\end{array}$

$\begin{array}{ll}\text { 6.2.3 Golven en sediment dynamiek } & 31\end{array}$

6.2.4 Ontwikkeling afwateringsgeulen $\quad 35$

$\begin{array}{ll}6.2 .5 & \text { Droogvalduur } \\ & 38\end{array}$

$\begin{array}{ll}6.2 .6 & \text { Sedimentsamenstelling } \\ 6.2 .7 & 39\end{array}$

6.2.7 Stroom- en golfmetingen 43

6.3 Ecologische ontwikkelingen 44

6.3.1 Benthische macrofauna 44

6.3.2 Ontwikkeling bodemdiergemeenschap in relatie tot omgevingsfactoren 65

$\begin{array}{lll}6.3 .3 & \text { Priming } & 67\end{array}$

$\begin{array}{lll}6.3 .4 & \text { Kokkelbestand Roggenplaat } & 78\end{array}$

$\begin{array}{ll}\text { 6.3.5 Oesterbanken } & 83\end{array}$

6.3.6 Laagwaterverspreiding steltlopers $\quad 83$

$\begin{array}{ll}\text { 6.3.7 Zeehondentellingen } & 94\end{array}$

7 Waterbeweging en -kwaliteit van het Middengeultje en nabij $\begin{array}{lr}\text { mosselpercelen } & 98\end{array}$

$\begin{array}{lll}7.1 & \text { Doel } & 98\end{array}$

$\begin{array}{llr}7.2 & \text { Turbiditeit en chlorofyl } & 99\end{array}$

$\begin{array}{lll}7.3 & \text { Benthische diatomeeën } & 103\end{array}$

$\begin{array}{ll}\text { 7.3.2 Resultaten: Per soort } & 106\end{array}$

$\begin{array}{ll}7.4 & \text { Metingen Sensorboot } \mathrm{HZ} \\ \end{array}$

8 Mosselpercelen rond de Roggenplaat: algemene karakteristieken en kwaliteit 
$\begin{array}{lll}8.1 & \text { Doel } & 110\end{array}$

8.2 Aanvoer van mosselen van de percelen 111

8.2.1 Aanvoer gehele Oosterschelde $\quad 112$

$\begin{array}{ll}\text { 8.2.2 Aanvoer Roggenplaat } & 114\end{array}$

$\begin{array}{ll}\text { 8.3 Ontwikkeling van de mosselen op de percelen } & 116\end{array}$

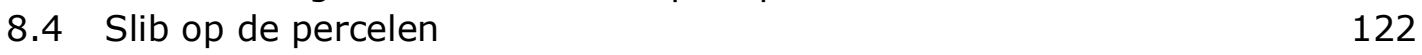

$\begin{array}{ll}8.5 \text { Onderwateropnames } & 125\end{array}$

9 Conclusies $\quad 126$

9.1 Veranderingen in de morfologie 126

$\begin{array}{ll}9.2 \text { Veranderingen in ecologie } & 127\end{array}$

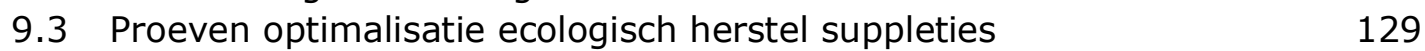

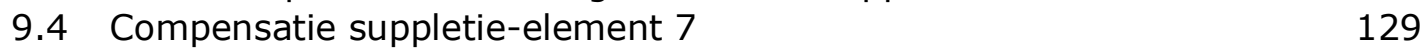

$\begin{array}{ll}9.5 \text { Voedselaanvoer Middengeultje } & 130\end{array}$

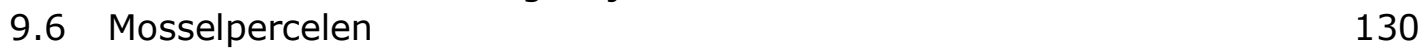

$\begin{array}{ll}9.7 \text { Concluderend } & 130\end{array}$

$10 \quad$ Kwaliteitsborging $\quad 132$

$\begin{array}{ll}\text { Literatuur } & 133\end{array}$

$\begin{array}{ll}\text { Verantwoording } & 136\end{array}$

Bijlage 1 Memo Boskalis: Toelichting Priming suppletievak $2 \quad 137$

$\begin{array}{lll}\text { Bijlage } 2 \text { Hoogte in cm NAP per droogvalduurklassen } & 143\end{array}$

$\begin{array}{lll}\text { Bijlage } 3 \text { Hoogte in cm NAP per droogvalduurklassen } & 153\end{array}$

$\begin{array}{lll}\text { Bijlage } 4 & \text { Voorkomen benthos } & 154\end{array}$

$\begin{array}{lll}\text { Bijlage } 5 & \text { Voorkomen benthos Suppleties } & 157\end{array}$

Bijlage 6 Benthos bemonstering veldscreening 159

$\begin{array}{lll}\text { Bijlage } 7 & \text { Resultaten Benthos Monitoring veldscreening } & 160\end{array}$

162

Bijlage 8 Aantal en samenstelling vogels over de tijd 165

$\begin{array}{lll}\text { Bijlage } 9 & \text { Methode Dataverwerking metingen Middengeultje } & 167\end{array}$ 


\section{Samenvatting}

\section{Achtergrond}

Als gevolg van de aanleg van de Oosterscheldekering en de compartimenteringsdammen treedt er in de Oosterschelde zandhonger op. De intergetijdengebieden eroderen en het vrijgekomen sediment komt in de getijdengeulen terecht, omdat het evenwicht tussen opbouw en afbraak van deze gebieden verstoord is. Het langzaam verdwijnen van intergetijdengebieden zal op termijn tot negatieve gevolgen leiden voor ecologie, veiligheid en recreatie. Intergetijdengebieden zijn van groot belang voor foeragerende steltlopers. Om de foerageerfunctie van de Oosterschelde voor steltlopers in stand te houden, is gekozen voor het suppleren van intergetijdengebieden. In dit kader heeft Rijkswaterstaat eind 2019 de Roggenplaat (1440 ha) gesuppleerd met ruim 1,13 miljoen $\mathrm{m}^{3}$ zand (in-situ volume), verdeeld over zeven suppletie-elementen (waarvan één suppletie-element is aangelegd ter compensatie voor de negatieve effecten van de vooroeverbestorting). De suppletie-elementen bedekken samen 211 hectare van de plaat en hebben een gemiddelde dikte van $30-80 \mathrm{~cm}$. Suppletie-elementen verschillen in hoogte en dikte. Gestreefd is vooral het areaal $50-80 \%$ droogvalduur met deze suppletie-elementen te doen toenemen, aangezien vooral deze hoogteligging waardevol foerageergebied levert. Deze hoeveelheid is vergelijkbaar met het ophogen van ruim 160 voetbalvelden met $1 \mathrm{~m}$ zand. Deze suppletie is uniek in zijn omvang, vormgeving en ligging. Niet eerder is er in Nederland, voor het behoud van ecologische waarden, een dermate grote hoeveelheid sediment direct op een intergetijdengebied gesuppleerd. Een grootschalige monitoring van de Roggenplaat loopt van 2015 tot en met 2024.

Monitoring is uitgevoerd met als doel het effect van de suppletie op de hydrodynamica, morfodynamica en ecologie te onderzoeken. Ook is er specifiek aandacht voor de kwaliteit van de omliggende mosselpercelen. Rijkswaterstaat heeft samen met Wageningen Marine Research, NIOZ, Deltares, Delta Project Management en de Hogeschool Zeeland vóór (T0; tot oktober 2019) tot 1 jaar na (T1; tot december 2020) aanleg van de suppletie onderzocht. De Roggenplaatdata vormen een unieke set, vanwege 1 ) het grote aantal meetlocaties, 2 ) de veelzijdigheid van de metingen zoals waterbeweging, zwevend stof, sedimentsamenstelling, morfologie, macrobenthos en vogels, en 3 ) de lange duur van deze metingen. De metingen dragen bij aan het begrip van veranderingen op de Roggenplaat als gevolg van de suppleties. Dit helpt het beheer van dergelijke gebieden te optimaliseren. De verzamelde data leren ons verder over de sturende fysische en ecologische processen in intergetijdengebieden, en de samenhang hiertussen. Tevens is in dit project aandacht voor de ontwikkeling van nieuwe monitoringsmethodes. Hieronder presenteren we kort de belangrijkste resultaten van de monitoringsdata met de focus op het verschil tussen de T0 en T1 situatie.

\section{Morfologie}

De foerageerfunctie voor vogels wordt bepaald door allerlei factoren, die voor deze rapportage zijn gemonitord. De bodemligging bepaalt hoelang de platen beschikbaar zijn voor foerageren en verandert door morfologische ontwikkelingen op de Roggenplaat. Abiotische condities, zoals de samenstelling van het bodemsediment, beïnvloeden het voorkomen van prooidieren voor vogels. De grootste veranderingen over de tijd voor aanleg van de suppletie zijn de erosie van de gehele plaat (vooral aan de zuidrand), en vermindering van het oppervlakte dat hoger ligt dan $+0.5 \mathrm{~m}$ NAP. Voor aanleg van de suppleties nam het areaal met een droogvalduur van $50-80 \%$ en $80-100 \%$ af, en areaal met een droogvalduur van $20-50 \%$ toe. Door aanleg van de suppleties is de 
bodemligging van de Roggenplaat gemiddeld hoger en is het areaal met een droogvalduur van $50-80 \%$ sterk toegenomen (met $\sim 130$ ha). De hoogste elementen, gelegen op het zuidelijke deel van de Roggenplaat, zijn het meeste in hoogte afgenomen in het eerste jaar na aanleg. Het zand waarmee de suppleties zijn aangelegd is gemiddeld $69 \mu \mathrm{m}$ grover dan het oorspronkelijk sediment. Afgezien van lokale sedimentatie en de vorming van een aantal afwateringsgeultjes naast de elementen lijkt de ontwikkeling van de rest van de Roggenplaat, inclusief de centrale afwateringsgeul het Middengeultje, vooralsnog niet substantieel beïnvloed door de aanwezigheid van de suppleties. Echter, de morfologische processen op de Roggenplaat na aanleg zijn nog in volle gang en het proces zal de komende jaren gevolgd blijven worden om de ontwikkelingen goed in kaart te brengen.

\section{Macrofauna}

Het voorkomen van bodemdieren is een belangrijke factor voor de geschiktheid van het gebied voor vogels. De soortenrijkdom en dichtheid verschillen ruimtelijk op de Roggenplaat, met lagere soorten aantallen en dichtheden op de zuidrand van de Roggenplaat en laaggelegen delen. Dit is na aanleg van de suppletie onveranderd. Dichtheden en soortenrijkdom op de suppleties zijn duidelijk lager en wijken in bodemdiergemeenschap af van de niet-gesuppleerde delen van de Roggenplaat. Ook tussen de suppletie-elementen zijn verschillen geobserveerd, met de laagste soortenrijkdom en dichtheden op suppleties die bestaan uit een dikkere gesuppleerde laag (over het algemeen ook een hogere bodemligging). Ook de bodemdiergemeenschap toont verschillen tussen dunne en dikke suppleties. De bodemdiergemeenschap op de suppletie die is aangelegd ter compensatie voor de negatieve effecten van de vooroeverbestorting wijkt af van de andere suppleties. De snelle veldscreening toont ook ruimtelijke variatie in soortenrijkdom tussen de suppletie-elementen, met laagste soortenrijkdom op dikke suppletie-elementen. Bij suppletiediktes van meer dan een $\mathrm{m}$ worden nauwelijks tot geen bodemdieren aangetroffen. Tussen 2019 en 2020 is het aandeel van het totale kokkelbestand van de Oosterschelde op de Roggenplaat gedaald. Veranderingen in kokkelbestand zijn echter moeilijk te linken aan de suppleties omdat slechts zeven bemonsteringspunten (WOT) binnen de suppletie vallen. Op deze locaties werden voorheen jaarlijks kokkels aangetroffen, maar na aanleg vinden we op enkel één punt kokkels. Het areaal van de Roggenplaat bedekt met oesterriffen is met zes ha afgenomen doordat een aantal suppletie-elementen nabijgelegen oesterriffen deels bedekt hebben.

\section{Priming}

Middels het actief aanbrengen van een bodemdiergemeenschap op de suppletie willen we het toekomstige herstel en ontwikkeling versnellen en in een gewenste richting sturen (d.i. de oorspronkelijke bodemdiergemeenschap herstellen), zodat de voedselfunctie voor vogels zo snel mogelijk na de ingreep weer op peil zou zijn. Hiervoor is een zogeheten priming experiment opgezet binnen de Roggenplaatsuppletie. De toegepaste nieuwe en experimentele vorm om aankomende suppleties van extra bodemleven te voorzien ("priming"), lijkt een duidelijk positieve uitwerking te hebben. Gezien het beperkte aantal monsters dat nu geanalyseerd is, kan dit nog niet definitief geconcludeerd worden. In verband met de Covid-maatregelen is het NIOZ zeer beperkt open geweest. Hierdoor hebben het Benthos en Analytisch lab slechts op $10 \%$ van de normale capaciteit mogen werken. Om deze reden is een groot deel van de genomen monsters nog niet verwerkt en geanalyseerd. De voorlopige resultaten laten zien dat er veel meer bodemleven in de "geprimde" gebieden zit, dan in de omliggende gesuppleerde delen. Hierdoor wordt er met priming dus sneller een beter foerageergebied voor vogels gecreëerd. Het is nu nog te vroeg om te zeggen welk effect 
dit heeft op het bodemleven van de direct omliggende suppletie, maar dit zal waarschijnlijk ook een positief effect hebben.

\section{Golven en sediment dynamiek}

Om te onderzoeken onder welke omstandigheden (bijv. bij stormen) veranderingen in bodemhoogte optreden kunnen continue hoogtemetingen verkregen uit de SED (Surface Elevation Dynamics sensoren)-sensoren in combinatie met de golfsensoren geanalyseerd worden. Door de samenloop van omstandigheden (Covid-beperkingen en vorst periode) is er nog geen uitgebreide statistische analyse op de beschikbare data uitgevoerd. Helaas is er door verlies van instrumenten ook een aantal data punten verloren gegaan. Desondanks zijn er genoeg metingen over om uiteindelijk wel een goed ruimtelijk beeld van de ontwikkeling van de bodem en de golfhoogtes te verkrijgen. De huidige resultaten moeten als preliminairy examples beschouwd worden, waar nu nog geen harde conclusies uit gehaald kunnen worden. Wat de voorlopige resultaten laten zien is dat de bodemhoogte aan de Oostkant van de Roggenplaat vrij stabiel is en dat de suppleties aan de westkant (vooral direct na aanleg) erosie vertonen.

\section{Vogels}

Het uiteindelijke doel van de suppletie Roggenplaat is het in standhouden van voldoende foerageergebied voor steltlopers waarvoor de Oosterschelde van internationaal belang is. Om het effect van suppleties op het foerageergebied van de Roggenplaat te begrijpen zijn laagwateraantallen, samenstelling en verspreiding van vogels voor en na de aanleg van de suppleties vergeleken. De suppleties lijken in grote lijnen geen invloed te hebben op aantallen, aantal soorten per teldag en de soortsamenstelling. De meest algemene soorten zijn nog steeds de bonte strandloper, rosse grutto, scholekster, wulp en zilverplevier (gemiddeld meer dan 1700 individuen per telling per soort). De dichtheden vogels tonen een verband met de benthosdichtheid, maar alleen in de periode tussen twee en vier uur na hoogwater. Ruimtelijk gezien zijn de hoogste aantallen vogels op het oostelijk deel van de Roggenplaat geteld. Dit is het gebied waar de bodem iets slibrijker is en hoge dichtheden van 1- en 2-jarige kokkels en nonnetjes voorkomen, die belangrijke prooisoorten zijn voor bepaalde vogelsoorten. Na aanleg van de suppleties zijn vogels nog steeds het meest talrijk aan de oostkant, maar suppleties lijken vermeden te worden. In de T1 zijn de vogeldichtheden op veel gebruikte plekken hoger vergeleken met de periode voor de suppleties. Dit komt mogelijk doordat de vogels de suppleties met lage benthosdichtheden vermijden. Vervolgonderzoek zal uitgevoerd worden naar de relatie tussen de verspreiding van vogelsoorten, droogvalduur en specifieke prooidieren.

\section{Zeehonden}

Zeehonden zouden mogelijk verstoord kunnen worden door de suppleties. De gewone zeehond is in de periode 2015-2018 stabiel gebleven in het Middengeultje en de Westgeul. De grijze zeehond is sinds 2018 niet meer gezien op de Roggenplaat, maar in 2020 werd 1 exemplaar weer waargenomen. De suppleties hebben geen duidelijke impact op de aantallen gewone zeehonden.

\section{Turbiditeit en chlorofyl}

Onderzocht is of het Middengeultje een belangrijke rol speelt in de voedselaanvoer voor de mosselpercelen die in de monding van dit geultje liggen. Turbiditeit en chlorofylgehalten tonen een vast patroon binnen het getijdencyclus voor aanleg, waarbij in het Middengeultje een piek bereikt wordt net voor hoog water. Dit patroon lijkt niet veranderd na de suppleties. Bentische en pelagische diatomeeën pieken bij de meeste meetpalen rond 1 uur na hoogwater. Rond de kentering komt het water tijdelijk stil te staan en kunnen algen neerslaan. Dit zou een toelevering van voedsel naar de 
mosselpercelen in de monding van het Middengeultje kunnen betekenen. In juni 2019 en mei 2020 bestonden diatomeeën voornamelijk uit pelagische soorten, en in november 2019 voor de helft uit bentisch en pelagisch soorten.

\section{Mosselpercelen}

De mosselpercelen langs de randen van de Roggenplaat, in het bijzonder de percelen in de monding van het Middengeultje, behoren tot de beste percelen van de Oosterschelde. Omdat men ongerust was dat de suppletie van de Roggenplaat zou leiden tot schade aan de mosselpercelen zijn deze intensief gemonitord voor, tijdens en na de suppletiewerkzaamheden. Uit de monitoring blijkt dat de percelen in de monding van het Middengeultje en in mindere mate de percelen aan de zuidzijde van de Roggenplaat intensief worden gebruikt door mosselkwekers. Sterfte van mosselen is, in het voorjaar van 2019, op meerdere locaties in de Oosterschelde aangetroffen en heeft tot veel schade geleid voor de mosselkwekers. Het is nog niet duidelijk waardoor deze sterfte is veroorzaakt. De sterfte op de percelen rond de Roggenplaats vond plaats ruim voordat is gestart met het aanbrengen van de suppleties.

In conclusie hebben de suppleties geleid tot een verhoging van het areaal met een droogvalduur van $50-80 \%$. Hiermee is het doel van de suppleties behaald: het vergroten/herstellen van belangrijk foerageergebied voor vogels. Dit gebied moet zich echter nog ontwikkelen tot ecologisch waardevol areaal. De suppleties worden echter nog amper gebruikt door vogels een jaar na aanleg. Dit komt hoogstwaarschijnlijk door de nu nog lage dichtheden benthos op de suppleties. De verwachting is dat vogels de suppleties weer gaan gebruiken, zodra ook benthosdichtheden herstellen. Mogelijk gaat de morfologie van de suppleties hier een rol spelen: benthosdichtheden zijn nu lager op de dikkere/hogere suppleties. Monitoring in de toekomst moet uitwijzen hoe benthos en vogeldichtheden zich gaan ontwikkelen, en of bepaalde morfologische kenmerken van de suppleties een rol zullen spelen. Een andere belangrijke bevinding is dat een jaar na de aanleg nog geen negatieve gevolgen zijn gevonden van de suppleties op de mosselkweek. 


\section{$1 \quad$ Inleiding}

\section{$1.1 \quad$ Achtergrond}

\subsubsection{Zandhonger}

De Oosterschelde is omwille van zijn biologische rijkdom aangewezen als Natura 2000gebied en samen met het Markiezaatmeer als Ramsar Wetland van Internationaal belang. Sinds 2002 is de Oosterschelde ook een Nationaal Park. De Oosterschelde is een belangrijk leefgebied voor kustbroedvogels, moerasbroedvogels en doortrekkende en overwinterende watervogels. In het kader van Natura 2000 is de Oosterschelde aangewezen voor zes habitat(sub)typen. Veruit het grootste habitattype wordt gevormd door het habitattype 'grote baaien' (H1160). Dit habitattype betreft het open water in de Oosterschelde, inclusief droogvallende platen en slikken. De Oosterschelde is het enige gebied in Nederland dat voor dit habitattype is aangewezen. Het habitattype wordt begrensd of door de hoogwaterlijn óf door de habitattypen 'zilte pionierbegroeiingen', 'slijkgrasvelden' en 'schorren en zilte graslanden' die ook iets onder de gemiddelde hoogwaterlijn kunnen voorkomen.

Door de aanleg van de stormvloedkering (voltooiing in 1986) in de monding van de Oosterschelde is er sprake van 'zandhonger' in het gebied. Het horizontale getij (i.e. de stroomsnelheid in de geulen) is afgenomen, waardoor het evenwicht tussen erosie en sedimentatie is verstoord. Bij rustig weer bouwt het intergetijdengebied niet voldoende op, terwijl er wel afbraak optreedt tijdens stormen. Hierdoor neemt het oppervlak van platen, slikken en schorren in de Oosterschelde af en wordt tevens de droogvalduur van het resterende intergetijdengebied verkort (Van Zanten en Adriaanse, 2008; de Ronde et al. 2013). Dit zal op termijn negatieve gevolgen hebben voor de natuurlijke kwaliteit en veiligheid van de Oosterschelde (Zandvoort et al. 2019). Van de natuurwaarden worden vooral het kenmerkende habitat voor steltlopers en watervogels bedreigd die voor hun voedsel afhankelijk zijn van de droogvallende slikken en platen.

\subsubsection{Suppleties}

Om na te gaan of de bovengenoemde negatieve effecten van de zandhonger zijn af te remmen of te stoppen heeft het ministerie van Infrastructuur \& Milieu en het ministerie van Economische Zaken in 2007 opdracht gegeven aan Rijkswaterstaat om een MIRTverkenning (Meerjarenprogramma Infrastructuur, Ruimte en Transport) uit te voeren (Witteveen en Bos, 2011). Uit deze MIRT-verkenning Zandhonger Oosterschelde volgde suppleren van het intergetijdengebied met zand om de foerageerfunctie van het gebied voor steltlopers in stand te houden. Ten behoeve van de MIRT-verkenning liepen destijds verschillende onderzoeken en praktijkproeven. Essentiële kennis werd gegenereerd in de deelprojecten Suppletiestrategieën, de ANT (Autonome Neerwaartse Trend Oosterschelde) Studie (de Ronde et al. 2013) en het programma Building with Nature (Witteveen en Bos, 2011). Daarnaast werd ook een aantal praktijkproeven uitgevoerd: Proefsuppletie Galgeplaat (Van der Werf et al., 2015), Cascadeproef Schelphoek, Veiligheidsbuffer Oesterdam (Boersema et al. 2019) en Duinvoetsuppletie Sophiastrand. De studies en praktijkproeven hebben kennis opgeleverd over hoe het suppleren van zand in het intergetijdengebied het beste aan te pakken. In Bestuurlijk Overleg MIRT 
Zeeland op 13 november 2014 is ervoor gekozen om als eerste de Roggenplaat te suppleren om de foerageerfunctie voor steltlopers in stand te houden middels suppleties.

Steltlopers foerageren tijdens laagwater op de droogvallende slikken en platen op zoek naar voedsel. Dit voedsel bestaat vooral uit bodemdieren zoals schelpdieren, wormen en kreeftachtigen. Daarbij moeten vogels voldoende lang kunnen foerageren om in hun energiebehoefte te voldoen. Vooral in de winter en de doortrekperiodes moeten steltlopers langer foerageren, in de Oosterschelde 6-9 uur per getij (Zwarts et al. 2011, de Ronde et al. 2013). Het areaal dat grofweg tussen de $50 \%$ en $80 \%$ van de tijd droogvalt is dus van groot belang en juist dit areaal neemt sterk af in de Oosterschelde. Op de Roggenplaat neemt deze droogvalduurklasse het snelste af van alle deelgebieden in de Oosterschelde (de Ronde et al. 2013, Witteveen en Bos 2013). Vanwege de urgentie besliste Rijkswaterstaat de Roggenplaat te suppleren ten behoeve van de volgende doelstellingen:

1. Behoud van de huidige foerageerfunctie van het Roggenplaat/Neeltje Janscomplex voor de komende 25 jaar.

2. Voorkomen van ongewenste golfaanval op de zuidkust van Schouwen.

3. Ontwikkelen van kennis voor flexibel, klimaatbestendig en kosteneffectief kustmanagement.

Hiertoe is ruim 1,13 miljoen $\mathrm{m}^{3}$ zand (in-situ volume) ingezet.

\subsection{Project Roggenplaatsuppletie}

Het hoofddoel van de suppletie van de Roggenplaat is "Behoud van de huidige foerageerfunctie van het Roggenplaat/Neeltje Jans-complex voor de komende 25 jaar" (van der Werf et al. 2016b). Dit doel komt voort uit de Natura2000 instandhoudingsdoelstellingen, in het bijzonder de Vogelrichtlijn (Rijkswaterstaat, 2015). Ten behoeve van de monitoring van de suppletie wordt de doelstelling aangescherpt tot het behoud van de foerageerfunctie van de Roggenplaat en wordt Neeltje Jans niet meegenomen in de monitoring. Het referentiejaar is bepaald op 2010, omdat dat het jaar is waarop de instandhoudingsdoelstellingen zijn gebaseerd (Rijkswaterstaat, 2015). Het doel van de suppletie kan dus nader gespecificeerd worden tot: in 2035 is de foerageerfunctie van de Roggenplaat gelijk of vergelijkbaar met de foerageerfunctie van de Roggenplaat in 2010 (van der Werf et al. 2016b).

De foerageerfunctie betreft 14 vogelsoorten - 13 steltlopers en de bergeend - die foerageren op intergetijdengebieden (van der Werf et al., 2016b):

1. Bergeend (Tadorna tadorna)

2. Bontbekplevier (Charadrius hiaticula)

3. Bonte Strandloper (Calidris alpina)

4. Groenpootruiter (Tringa nebularia)

5. Kanoet (Calidris canutus)

6. Kluut (Recurvirostra avosetta)

7. Rosse Grutto (Limosa lapponica)

8. Scholekster (Haematopus ostralegus)

9. Steenloper (Arenaria interpres)

10. Strandplevier (Charadrius alexandrinus)

11. Tureluur (Tringa totanus)

12. Wulp (Numenius arquata)

13. Zilverplevier (Pluvialis squatarola) 
Oorspronkelijk bestond het project uit de volgende drie fasen: Planfase (2015-2016), Uitvoeringsfase (2017-2018) en Evaluatiefase (2019-2024). De Planfase omvatte onder meer de volgende onderdelen: Winplaatsenonderzoek, geotechnisch onderzoek, voorkomen van schade aan mosselkweek, variantenstudie en definitief ontwerp, monitoringsplan, stakeholderinspraak en vergunningaanvraag, en een $T_{0}$ monitoring en beschrijving (uitgangssituatie vóór suppletie). Door een aanvechting bij de Raad van State door mosselkwekers is het project Roggenplaatsuppletie echter vertraagd en is pas op 6 februari 2019 de definitieve uitspraak gekomen dat Rijkswaterstaat het project kon uitvoeren. De uiteindelijke uitvoering van de suppletie zelf heeft vervolgens plaatsgevonden in de periode oktober - december 2019.

Door dit uitstel is de T0 monitoring over een langere tijdsduur uitgevoerd, tot oktober 2019. De eerste resultaten van de monitoring, gerapporteerd in Ysebaert et al. (2016), vormde de basis van het uiteindelijke monitoringsplan Roggenplaatsuppletie (Ysebaert et al. 2017). Daarnaast zijn deze eerste data gebruikt voor de nadere beoordeling en selectie van de suppletievarianten op basis van de modellering. Daarom is een deel van de T0 resultaten ook gepresenteerd en deels besproken in de variantenstudie en het definitief ontwerp (van der Werf et al. 2016a en 2016b).

Naast het monitoringsplan van Ysebaert et al. (2017), dat als doel heeft de hierboven gestelde doelstelling van de Roggenplaatsuppletie te onderzoeken en te evalueren, is een plan opgesteld voor de zogenaamde risicomonitoring (Wijsman en Kraan, 2017). Deze risicomonitoring is bedoeld om eventuele negatieve effecten op nabijgelegen mosselkweekpercelen in kaart te brengen.

Het voorliggende rapport is een evaluatierapport en gaat in op de resultaten van de onderzoeks- en monitoringsactiviteiten die zijn uitgevoerd binnen het project Roggenplaatsuppletie vóór en één jaar na aanleg van de suppletie. Voor bepaalde onderdelen worden verbanden gelegd tussen morfologie en ecologie. Dit helpt ons in algemene zin kennis te vergroten over het functioneren van getijdenplaten. Deze verbanden zullen de komende vier jaar nader worden onderzocht. Beperkingen in veldbezoeken en lab-analyses door de covid-19 pandemie hebben ertoe geleid dat een deel van de analyses nog in uitvoering zijn op het moment van deze rapportage. De resultaten hiervan zullen later gerapporteerd worden. 


\section{$2 \quad$ Rolverdeling en verantwoording}

Wageningen Marine Research is gevraagd invulling te geven aan de monitoring en te dienen als trekker voor de T0- en T1-monitoring en beschrijving in samenwerking met de consortiumpartners Hogeschool Zeeland, NIOZ en Deltares.

Om een zo volledig mogelijk beeld te schetsen zijn onderdelen overgenomen uit eerdere rapporten:

Hoofdstuk 4 is gebaseerd op het aanlegdocument Suppletie Roggenplaat.

Hoofdstukken 5, 7 en 8 zijn geschreven door Wageningen Marine Research. Een samenvatting van de metingen uitgevoerd met de sensorboot door de Hogeschool Zeeland is opgenomen in hoofdstuk 8 . Voor een uitgebreid rapport verwijzen wij naar Trouwborst et al. 2021.

Hoofdstuk 6 en 9 zijn geschreven door Deltares (Morfologie), NIOZ (priming) en Wageningen Marine Research. DPM heeft data aangeleverd voor Hoofdstuk 6. 


\section{Leeswijzer}

Dit rapport is opgedeeld in verschillende hoofdstukken die een overzicht geven van het onderzoek en de monitoring zoals uitgevoerd in het kader van de Roggenplaatsuppletie. Voor de hoofdstukken waarin resultaten beschreven worden is voor elk subonderdeel een korte beschrijving gegeven van de methodiek indien deze afwijkt van de T0, en anders een verwijzing naar de methodiek beschreven in de T0 rapportage (Walles et al. 2021), direct gevolgd door de resultaten.

Het rapport bestaat uit de volgende hoofdstukken:

\section{Aanleg suppletie}

In dit hoofdstuk wordt de aanleg van de suppletie en de proeven ten behoeve van optimalisatie ecologisch herstel van de suppletie (zogenaamde priming) beschreven.

\section{T0 en T1 monitoring: een overzicht van de uitgevoerde activiteiten}

In dit hoofdstuk worden alle metingen die zijn uitgevoerd in het kader van de T0- en T1monitoring op een rijtje gezet. De T0 metingen zijn gestart in 2015 en lopen tot oktober 2019, het moment van de start van de aanleg van de Roggenplaatsuppletie. De T1 metingen lopen van tijdens de aanleg (oktober - december 2019) tot één jaar na aanleg (december 2020).

\section{Recente morfologische en ecologische toestand en ontwikkeling van de Roggenplaat;}

In dit hoofdstuk worden de resultaten getoond van de morfologische en ecologische toestand en ontwikkeling van de Roggenplaat op basis van de uitgevoerde monitoring sinds 2015.

\section{Waterbeweging en -kwaliteit van het Middengeultje en nabij de mosselpercelen;}

In dit hoofdstuk worden de resultaten getoond van de waterbeweging en -kwaliteit van het Middengeultje en nabij de mosselpercelen op basis van de uitgevoerde monitoring sinds 2015. Deze data zijn gebruikt om te onderzoeken of suppleties een effect hebben op voedselaanvoer naar de mosselpercelen.

\section{Mosselpercelen rond de Roggenplaat: algemene karakteristieken en kwaliteit}

Een van de zorgpunten zijn de consequenties van de suppletie voor de mosselpercelen rondom de Roggenplaat. In dit hoofdstuk worden de resultaten getoond van de karakteristieken en kwaliteit van de mosselpercelen rond de Roggenplaat op basis van de uitgevoerde monitoring vóór en na aanleg van de suppleties. 


\section{Conclusies}

In dit hoofdstuk blikken we terug op de evaluatie en kennisvragen aan de hand van de ingewonnen data. Tevens staan we stil bij de ontwikkeling van suppletie-element 7, de suppletie die is aangelegd ter compensatie voor de negatieve effecten van de vooroeverbestorting. 


\section{$4 \quad$ Aanleg suppletie}

In het najaar van 2019 is de Roggenplaatsuppleties aangelegd door baggermaatschappij Boskalis. In totaal zijn 7 suppletie-elementen gerealiseerd: 6 in het kader van de bestrijding van de zandhonger (suppletie-element $1 \mathrm{t} / \mathrm{m} 6$ ) en één suppletie (element 7) voor het compenseren van significant negatieve effecten op het habitattype grote baaien (H1160), Figuur 4-1. De vooroevers bij Burgsluis, Schelphoek en Zierikzee zijn in 2014 in totaal over een oppervlakte van 11,2 hectare, met breuksteen en zeegrind, bestort. Na bestorting was er sprake van een significant negatief effect op het habitattype grote baaien ( $\mathrm{H} 1160)$. Maatregelen gericht op een kwaliteitsverbetering van dit habitattype, specifiek in het intergetijdengebied, dragen het sterkste bij aan het realiseren van de instandhoudingsdoelen van het Natura 2000-gebied. In de conclusie gaan we specifiek in op de ontwikkelingen van suppletie-element 7.

Randvoorwaarde voor de aanleg van suppletie-elementen 1 t/m 6 was binnen de geplande contouren een minimale hoogte (deze verschilde per suppletie tussen $+0,30$ m NAP en + 0,67 m NAP) te bereiken door gebruik van zoveel mogelijk sediment binnen het beschikbare budget. De minimale hoogte van $+0,67 \mathrm{~m}$ NAP was een randvoorwaarde voor suppletie-elementen 4, 5 en 7. Opgemerkt wordt dat in het oorspronkelijke ontwerp (van der Werf et al. 2016b) deze hoogte ook gold voor suppletie-element 6 . Hier is in het bestek vanaf geweken om voldoende vrijheid aan de aannemer te geven binnen het beschikbare volume en budget. Voor suppletie-element 7 gold verder de randvoorwaarde van een minimale oppervlakte van 11,7 ha. De contouren die in Figuur 4-1 zijn aangegeven betreffen het oorspronkelijke ontwerp. Hier is in de aanleg enigszins van afgeweken in verband met de draagkracht voor de machines en het beschikbare volume. De daadwerkelijk gerealiseerde suppletie-contouren zijn gepresenteerd in paragraaf 6.2.2 op basis van de LiDAR metingen.

Sediment werd gewonnen uit de winplaats de Roompot, ten zuidwesten van de Roggenplaat. De winplaats ligt op een locatie waar sinds de aanwezigheid van de stormvloedkering aanzienlijke sedimentatie van zand, met nauwelijks slibdeeltjes, heeft plaatsgevonden. Het zand is door een sleephopperzuiger naar de koppelplaats van de persleidingen getransporteerd. Vervolgens is het schip gekoppeld aan de persleidingen en is het zand naar de suppletieplaatsen geperst (Figuur 4-2). Tijdens laag water, gedurende de dag en nacht, is het zand op de suppletie door bulldozers in de gewenste vorm geschoven. Dit proces nam 3 maanden in beslag (16 oktober tot 29 december). 


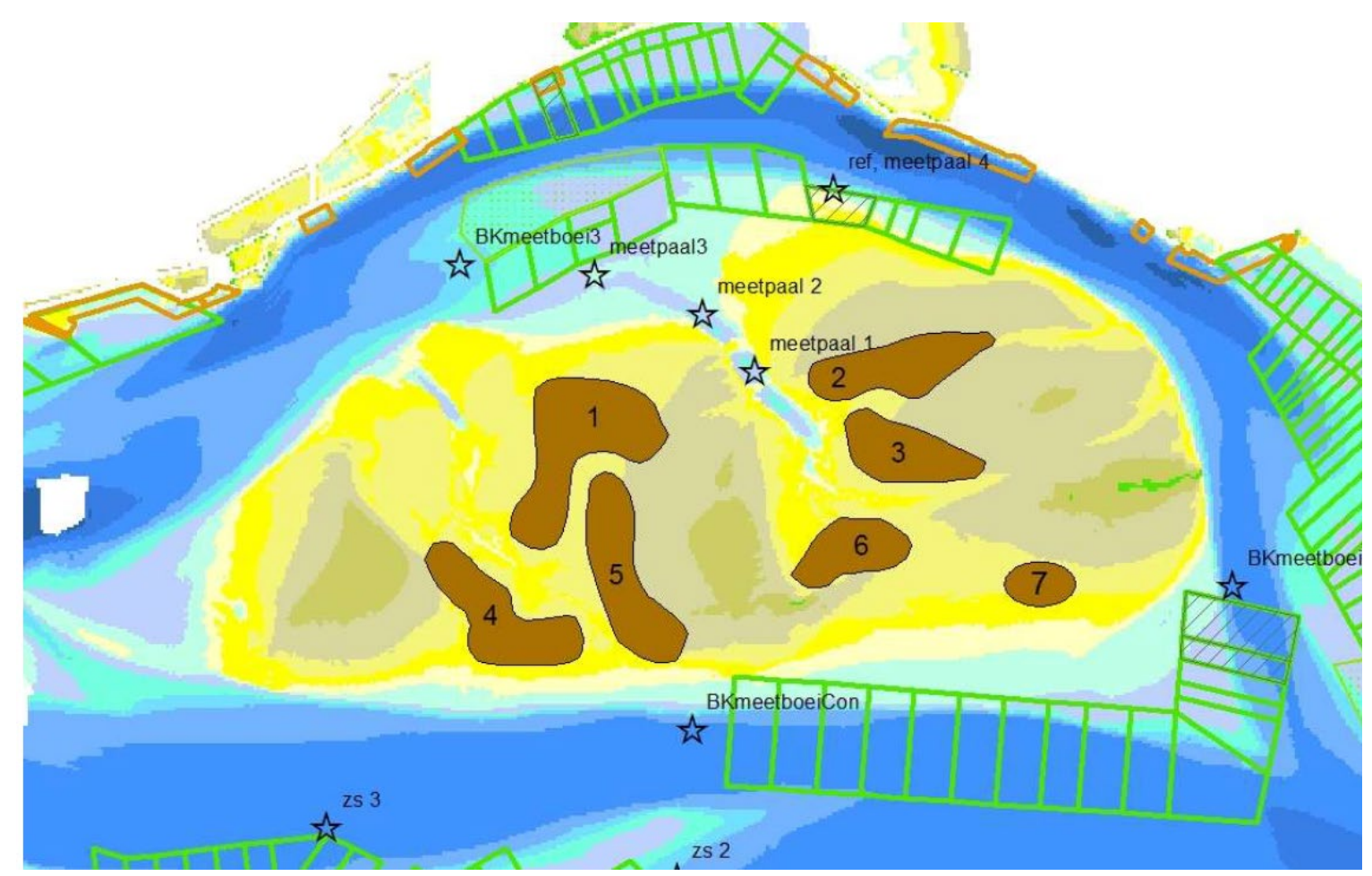

Figuur 4-1 Geplande suppletie-elementen in bruin. De mosselpercelen zijn aangegeven in groen.

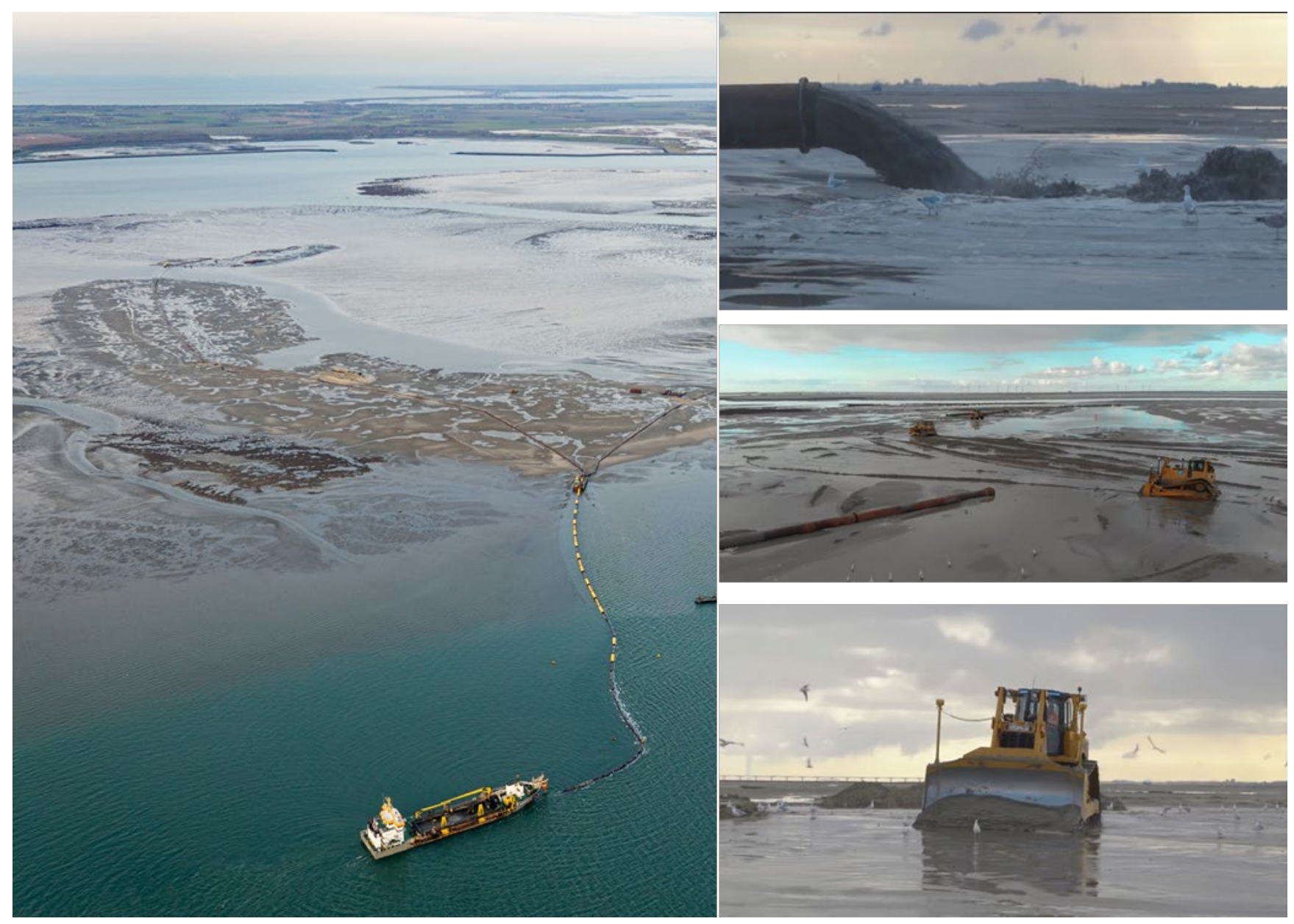

Figuur 4-2 Sleephopperzuiger aangekoppeld aan persleidingen (links), zand dat geperst wordt naar de suppletieplaats (rechtsboven) en bulldozers die het zand verplaatsen (rechtsmidden en -onder). Linker foto: Edwin Paree, Rechter foto's: beelden uit de video "Zeeuwse Roggenplaat: wegrestaurant voor trekvogels" RWS. 
Tabel 1 geeft een overzicht van de ontworpen in situ volumes (in totaal 1,13 miljoen $\mathrm{m}^{3}$ ) en de daadwerkelijk gesuppleerde in situ volumes (in totaal ook 1,13 miljoen $\mathrm{m}^{3}$ ), zoals door Boskalis bepaald in 2019 middels drone metingen. Opgemerkt wordt dat het hier vermelde ontwerpvolume van 1,13 miljoen $\mathrm{m} 3$ afwijkt van het ontwerpvolume van 1,3 miljoen m3 uit Van der Werf et. al. (2016b). Dit is het gevolg van een vertaling van het ontwerp in de aanbestedingsfase naar variabele eisen met betrekking tot minimale en maximale hoogten van de suppleties. Verder is het ontwerp van suppletie-element 1,6 en 7 aangepast in verband met de draagkracht van de bodem voor de machines. De oppervlakte van suppletie-element 7 bedroeg na aanleg 11,8 ha.

Tabel 1 Per suppletie-element de aanleg periode, het gesuppleerde volume en de hoogte. Dit zijn de door Boskalis ingemeten waarden op de in de laatste kolom vermelde datums (memo Boskalis 2020).

\begin{tabular}{|c|c|c|c|c|c|}
\hline $\begin{array}{l}\text { Suppletie } \\
\text {-element }\end{array}$ & Aanleg periode & $\begin{array}{l}\text { Volume } \\
\text { ontwerp }\end{array}$ & $\begin{array}{l}\text { Volume } \\
\text { gesuppleerd }\end{array}$ & Aanleg hoogte & Datum uitmeting \\
\hline 1 & 17 nov -16 dec & $229.067 \mathrm{~m}^{3}$ & $213.950 \mathrm{~m}^{3}$ & $+0,30$ m NAP & 16 dec 2019 \\
\hline 2 & 16 okt - 29 okt & $129.866 \mathrm{~m}^{3}$ & $130.177 \mathrm{~m}^{3}$ & $+0,30$ m NAP & 4 nov 2019 \\
\hline 3 & 3 nov -15 nov & $89.304 \mathrm{~m}^{3}$ & $81.180 \mathrm{~m}^{3}$ & $+0,30$ m NAP & 18 nov 2019 \\
\hline 4 & 30 nov - 29 dec & $295.069 \mathrm{~m}^{3}$ & $318.206 \mathrm{~m}^{3}$ & $\begin{array}{l}19 \text { ha op ca. }+0,67 \mathrm{~m} \\
\text { NAP; overige }+0,30 \\
\text { m NAP }\end{array}$ & 30 dec 2019 \\
\hline 5 & 16 okt - 17 nov & $233.649 \mathrm{~m}^{3}$ & $245.432 \mathrm{~m}^{3}$ & $+0,67$ m NAP & 17 nov 2019 \\
\hline 6 & 15 nov - 30 nov & $78.929 \mathrm{~m}^{3}$ & $74.211 \mathrm{~m}^{3}$ & $+0,30$ m NAP & $1 \operatorname{dec} 2019$ \\
\hline 7 & 21 nov - 26 nov & $73.884 \mathrm{~m}^{3}$ & $71.072 \mathrm{~m}^{3}$ & $+0,67$ m NAP & 26 nov 2019 \\
\hline
\end{tabular}

Tijdens de aanleg is de zetting van de suppleties gemonitord. Ook na aanleg heeft er nog zetting plaatsgevonden. Omdat de zetting relevant is voor de volumebalans van de suppletie-elementen worden de metingen van de zetting in ieder geval tot en met 2021 nog uitgevoerd.

\subsection{Proeven optimalisatie ecologisch herstel suppletie}

Door te suppleren ontstaat er tijdelijk een habitat waarin geen bodemdieren voorkomen. Het oorspronkelijke bodemleven wordt bedolven onder een laag zand en sterft af en in het gesuppleerde sediment komt nauwelijks bodemleven voor. Onderzoek heeft aangetoond dat de kolonisatiesnelheid van gesuppleerde habitats sterk van soort tot soort kan verschillen. Tevens bieden dergelijke 'lege' habitats in potentie exoten de kans om zich te vestigen. Middels het actief aanbrengen van een bodemdiergemeenschap op de suppletie willen we het toekomstige herstel en ontwikkeling versnellen en in een gewenste richting sturen (d.i. de oorspronkelijke bodemdiergemeenschap herstellen), zodat de voedselfunctie voor vogels zo snel mogelijk na de ingreep weer op peil zou zijn. Hiervoor is een zogeheten priming experiment opgezet binnen de Roggenplaatsuppletie (Ysebaert et al. 2017). De bedoeling van primen is het overbrengen van bodemleven en gebiedseigen sediment (zogenaamde primelaag), zodat het bodemleven zich versneld kan herstellen ten opzichte van het nieuw gesuppleerde zand waarin nog geen bodemleven aanwezig is. Hiervoor is plaatmateriaal afgeschraapt van $\pm 22 \mathrm{~cm}$ dikte. $\mathrm{Er}$ zijn door Boskalis drie plots met een schaal van 50x100m geprimed op het noordoostelijk gelegen suppletie-element (suppletie-element 2) (Figuur 4-3). Dit was de eerste priming van dit formaat. Omdat het uitvoeren van een priming geen gebruikelijke methode is heeft dit tot technische uitdagingen geleid die geresulteerd hebben in verschillen tussen de geprimede vakken. Hieronder volgt een korte beschrijving van de aanleg op basis van de memo van Boskalis (zie Bijlage 1). Op 5 oktober 2019 is begonnen met het primen van het meest oostelijke vak. Middels een kraan is de bovenste $22 \mathrm{~cm}$ van het slik opgegraven en op een rug gelegd. Een shovel heeft vervolgens dit sediment vervoerd 
en aangebracht op de gewenste priming locatie. Het afgraaf vak (donor locatie) en prime vak lagen aanvankelijk naast elkaar. Voor de shovel bleek echter het niet werkbaar om het donorgebied te vermijden. Doordat de shovel over de af te graven bodem reed leidde dit tot verstoring van het bodemleven (compactie). Besloten is om alleen onverstoorde bodem op te graven met de kraan en dit op ruggen te leggen. De shovel brengt deze vervolgens op de priming locatie aan door geleidelijk achteruit te rijden en het zand uit de bak te laten glijden. Het zand is hierdoor op ruggen komen te liggen in de priming locatie. Na enkele getijden vlakten deze zandhopen geleidelijk af. Op deze wijze kwam er een laag zand in het prime vak die de gewenste dikte redelijk benaderde.

Het bleek niet mogelijk om de bovenkant van de afgegraven toplaag als bovenkant op de priming vak te krijgen. De aangebrachte priming is een gemengde laag geworden van het $22 \mathrm{~cm}$ diep afgegraven omliggende slik. Eerste visuele inspectie liet zien dat wormen hierdoor beschadigd werden. Een deel bleef echter wel leven, gezien de vorming van faeceshoopjes twee dagen na aanleg.

Bij Prime vak 2 bleek de bodem slapper te zijn, waardoor de shovel gelijk sporen trok in het slik. In eerste instantie is gewerkt met een halve laadbak per keer. Hierdoor kwam er minder priming laag in vak 2. Door de spoorvorming van de shovel raakte de onderlaag zodanig verstoord dat deze werkwijze niet lang werkbaar was. Besloten was middels de kraan in 1, 2 of 3 keer het sediment te verplaatsen richting het prime vak. De afweging was wel dat het bodemleven dan meer verstoord zou worden, maar wel de toplaag van de donor locatie bovenop kwam liggen. De dikte van deze priming laag was minder dan vak 3. Na enkele tijen zag de toplaag er redelijk uit.

Verwacht werd dat de bodem bij prime vak 1 nog slapper zou zijn wegens de nabij gelegen geul. Besloten was hier alleen met de kraan te werken. Omdat de bodem toch iets steviger was is ook hier de shovel ingezet voor het uitrijden van het sediment van de ruggen naar de priming locatie. Door de inzet van de kraan is de primelaag van vak 1 egaler geworden dan de laag in vak 3. Op 10 oktober 2019 is de priming afgerond. $\mathrm{Na}$ afronding zijn de omliggende gebieden gesuppleerd met sediment uit de winplaats Roompot. 


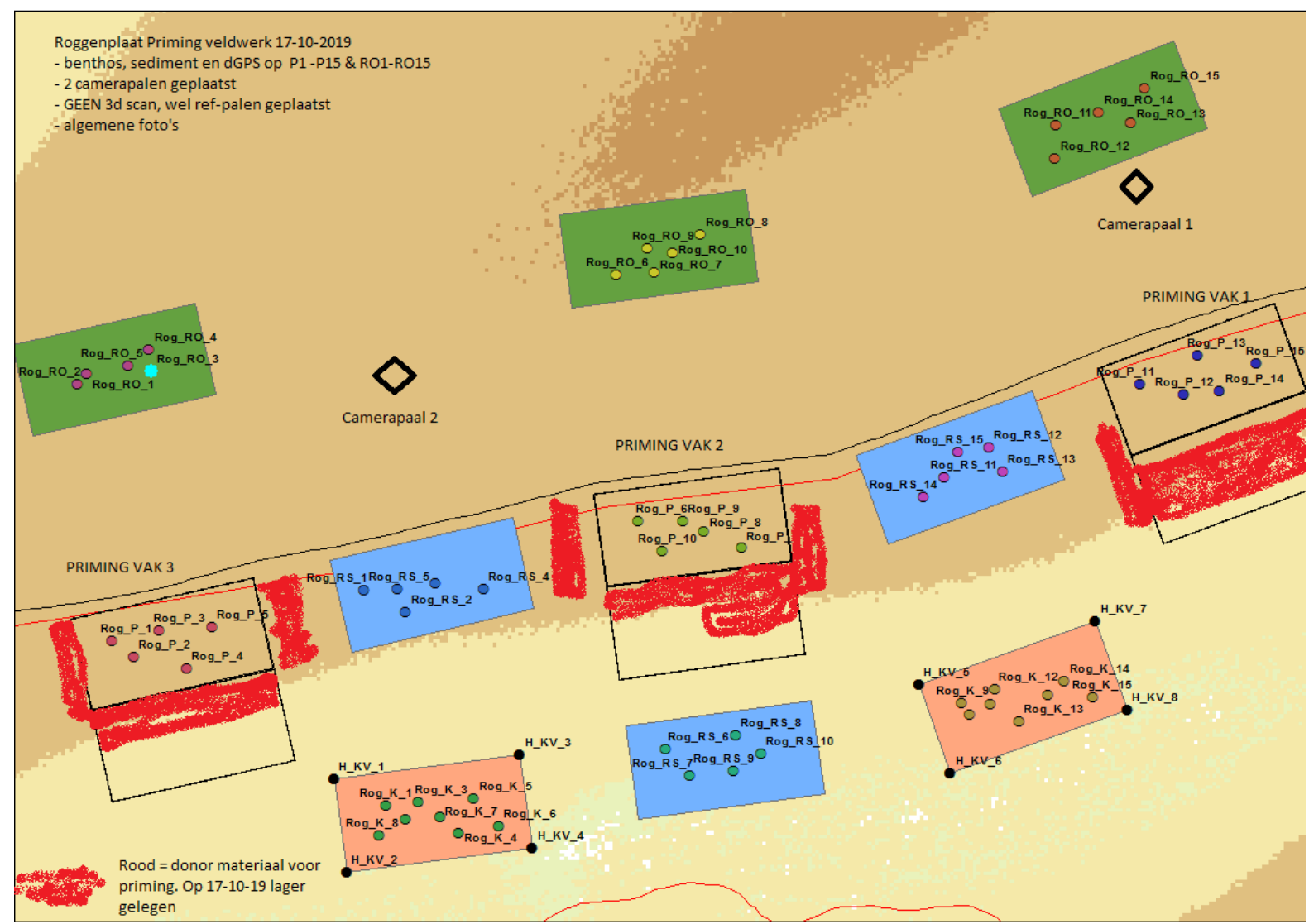

Figuur 4-3. Overzicht bemonstering priming suppletie-element 2. Zwartomlijnde vakken geven (van rechts naar links) priming vak 1, 2 en 3 weer met per vak 5 monsterlocaties. Groene en blauwe vakken zijn referentievakken buiten de suppletie (groen) en op de suppletie (blauw) met in elk vak 5 monsterlocaties. In de roze vakken zijn alleen kokkels aangebracht. Hier bevinden zich 8 monsterlocaties per vak. De rode gebieden geven aan waar het materiaal voor de priming met gebiedseigen materiaal afkomstig van was.

$\mathrm{Na}$ afronding van de aanleg van suppletie-element 2 is een priming middels het uitstrooien van kokkels, op gesuppleerd zand afkomstig uit de winplaats, uitgevoerd binnen twee plots met een schaal van 50×100 m (zie Bijlage 2). De kokkels waren afkomstig van delen van de Roggenplaat waar suppletie-elementen 5 en 6 op zijn gesuppleerd. Kokkels zijn hier, voor het suppleren, opgevist gebruikmakend van een handbeugel (Figuur 4-4) en de waterlift (Figuur 4-5). In totaal zijn 16,4 ton kokkels gevist in 27,5 uur tijd (3,5 ton met de hand (13 uur) en 12,9 ton met de waterlift $(14,5$ uur)). Dit is het nettogewicht, waarbij een klein deel lege schepen zijn en circa 3-5\% tapijtschelpen. Met elk hoogwater zijn vervolgens de kokkels verstrooid op suppletie 2 binnen de twee vakken (zie roze vakken Figuur 6-47). Omgerekend is 8,1 ton op het westelijke vak verzaaid en 7,8 ton op het oostelijke vak. Het verzaaien gebeurde met een rubberboot waaruit de viskisten geleidelijk werden geleegd. De kokkels groeven zich vrijwel gelijk weer in, naar schatting $95-98 \%$ na het eerste tij. $\mathrm{Er}$ is geen sterfte waargenomen tijdens de diverse keren van verzaaien. 

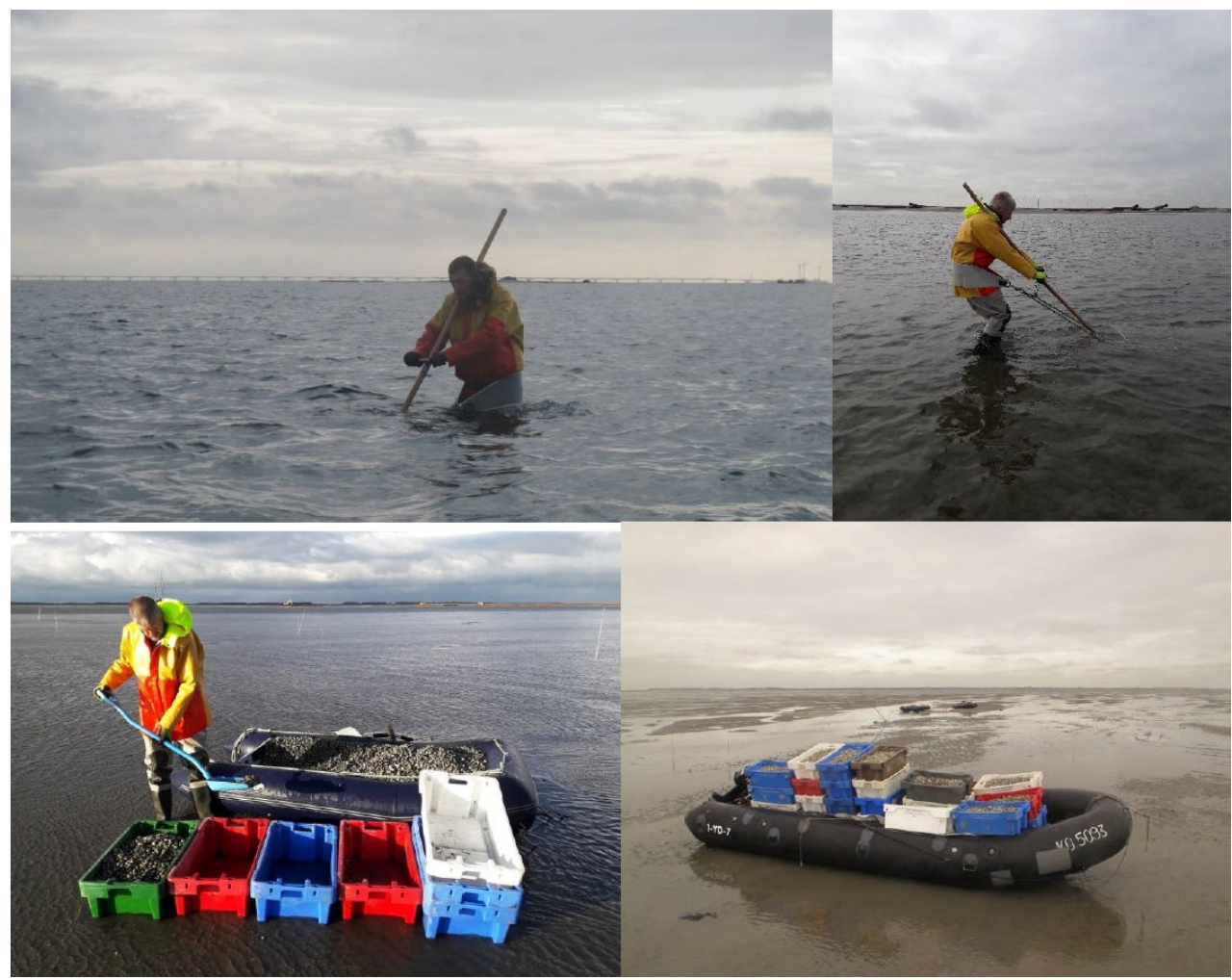

Figuur 4-4. Handmatig kokkels vissen met de handbeugel. Bij laagwater is de vangst omgeschept in viskisten om te verzaaien. Foto: Boskalis.

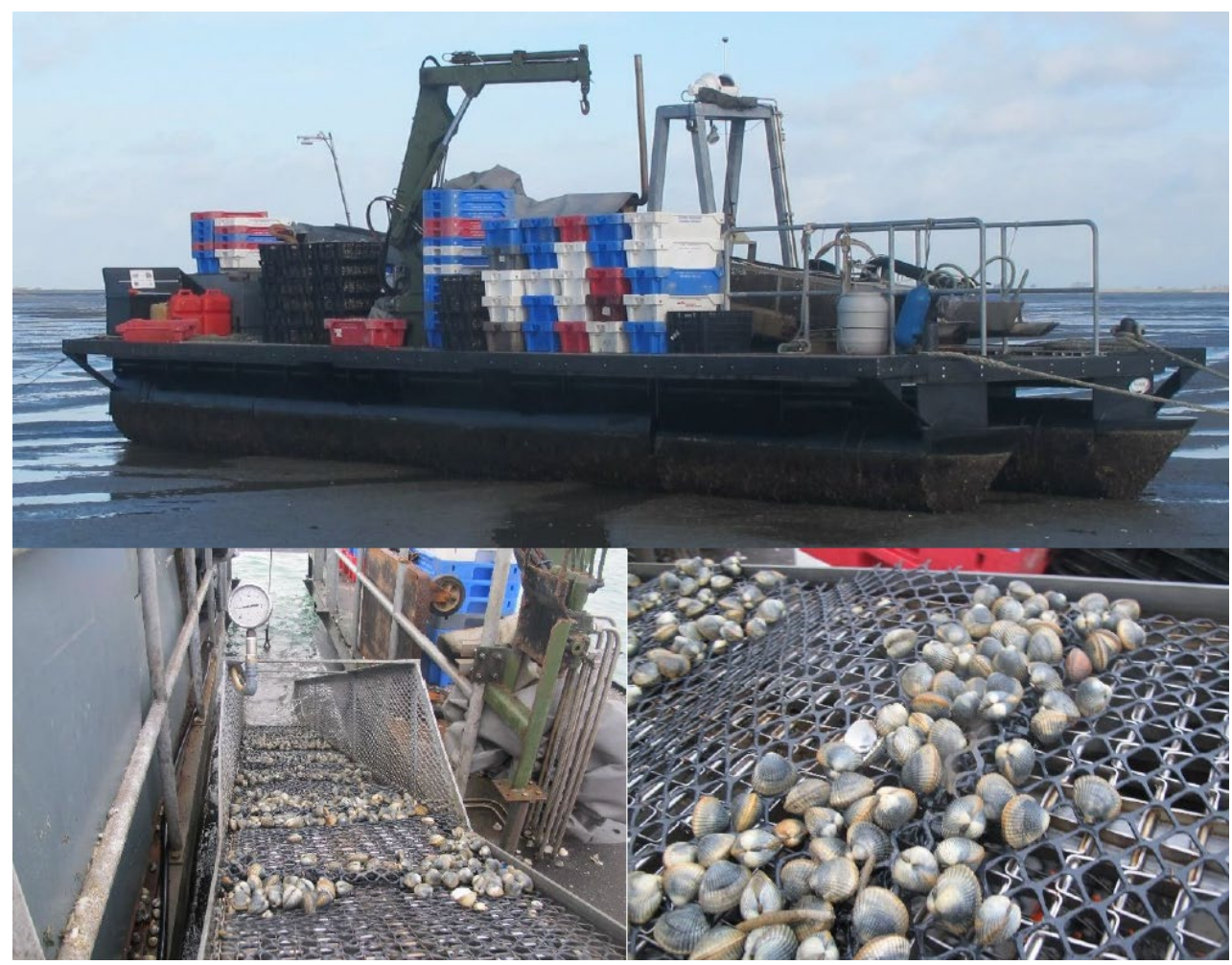

Figuur 4-5. Mechanisch kokkels vissen met de waterlift. Foto: Boskalis. 


\section{T0 en T1 monitoring: een overzicht van de uitgevoerde metingen en activiteiten}

De verschillende monitoringsactiviteiten staan beschreven in de monitoringsplannen (Ysebaert et al. 2017, Wijsman \& Kraan 2017). De monitoring maakt deels gebruik van lopende monitoring en bestaat deels uit nieuwe monitoring. In Tabel 2 staat aangegeven welke metingen uitgevoerd zijn in het kader van de T0 en T1 monitoring voor (tussen januari 2015 en september 2019), tijdens (oktober - december 2019), en na (januari 2020 - februari 2021) aanleg van de suppleties. Nadere details over meetlocaties en -momenten zijn opgenomen in Hoofdstuk 6, 7 en 8.

Tabel 2 Monitoringsactiviteiten tussen januari 2015 en februari 2021. Per onderdeel staat aangegeven wanneer welke metingen uitgevoerd zijn.

\begin{tabular}{|c|c|c|c|c|c|c|c|c|c|}
\hline & & 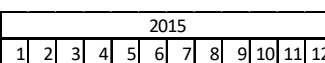 & 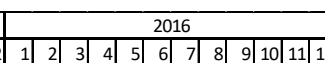 & 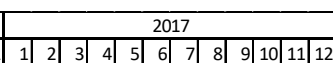 & 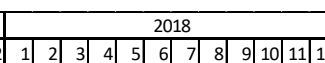 & 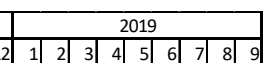 & \begin{tabular}{|l|}
2019 \\
10111122 \\
\end{tabular} & 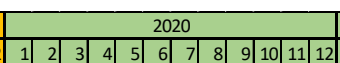 & \begin{tabular}{|l|}
20212 \\
$2 \mid 2$
\end{tabular} \\
\hline Fysische metingen & \begin{tabular}{|l|} 
stroom- en golfmetingen \\
LDAR \\
RTK \\
Sedimentsamenstelling \\
\end{tabular} & & 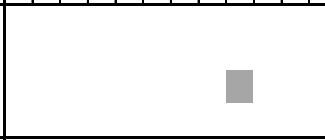 & 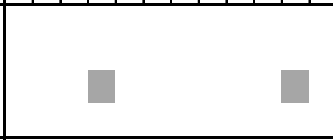 & & & & $x_{1}$ & \\
\hline Ecologische metingen & $\begin{array}{l}\text { Verspreiding bodemdieren } \\
\text { kwalitatieve benthosopname } \\
\text { WOT kokkels } \\
\text { WOT oesters } \\
\text { Laagwatertellingen vogels } \\
\text { Zeehondentellingen MWTL }\end{array}$ & 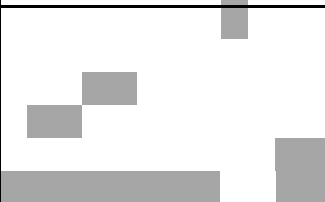 & 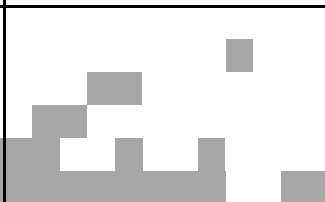 & + & $\S$ & & 2 & & \\
\hline $\begin{array}{c}\text { Waterbeweging en - } \\
\text { kwaliteit Middelgeultje }\end{array}$ & $\begin{array}{l}\text { Multi-Beam } \\
\text { stroom metingen } \\
\text { diatomeeën }\end{array}$ & E & & & 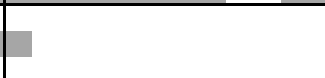 & & & & \\
\hline $\begin{array}{l}\text { Mosselpercelen rond de } \\
\text { Roggenplaat: algemene } \\
\text { karakteristieken en }\end{array}$ & $\begin{array}{l}\text { perceelbemonstering } \\
\text { steekbuizen } \\
\text { onderwatercamera }\end{array}$ & & & & & & & & \\
\hline priming & $\begin{array}{l}\text { bemonstering } \\
\text { 3D scan } \\
\text { sed sensoren } \\
\text { golf loggers }\end{array}$ & & & & & & & & \\
\hline
\end{tabular}




\section{Recente morfologische en ecologische toestand en ontwikkeling van de Roggenplaat (T0 en T1)}

\subsection{Doel}

In dit hoofdstuk worden de resultaten getoond van de morfologische en ecologische toestand en ontwikkeling van de Roggenplaat op basis van de uitgevoerde metingen sinds 2015. Dit betreft de T0 en T1 situatie. De metingen van de T1 situatie worden met de T0 metingen vergeleken. Voor de lange-termijn ontwikkeling van de morfologie wordt verwezen naar Hoofdstuk 4 in Walles et al. (2021).

\subsection{Morfologische ontwikkelingen}

Het areaal droogvalduur is een centrale doelindicator voor het evalueren van de Roggenplaatsuppletie. De ontwikkeling van het areaal droogvalduur is direct gekoppeld aan de morfologische ontwikkeling van de Roggenplaat. Voor het onderzoeken van de morfologische ontwikkeling van de Roggenplaat zijn verschillende metingen uitgevoerd. Middels deze metingen wordt onderzocht: (1) welke processen ten grondslag liggen aan veranderingen in areaal droogvalduur op de Roggenplaat; (2) wanneer en waar erosie optreedt en hoe het sediment zich verplaatst over de Roggenplaat. Na aanleg van de suppleties kan tevens onderzocht worden hoe de individuele suppletie-elementen zich morfologisch ontwikkelen en of dit afhankelijk is van de locatie op de Roggenplaat. Specifiek wordt hierbij gekeken naar locaties waar erosie en sedimentatie optreden, hoe het sediment zich verplaatst over de Roggenplaat en of er niet-gesuppleerde gebieden (geulen, intergetijdengebieden) zijn die beïnvloed worden door de aanwezigheid van de suppleties. Om te onderzoeken onder welke omstandigheden (bijv. bij stormen) veranderingen in bodemhoogte optreden kunnen continue hoogtemetingen verkregen uit de SED (Surface Elevation Dynamics sensoren)-sensoren in combinatie met de golfsensoren geanalyseerd worden. De T1 metingen geven met één jaar aan data nog te beperkt zicht op de levensduur van de suppletie-elementen. Pas in vervolgrapportages kan dus worden bepaald of de beoogde levensduur van de suppletie-elementen behaald lijkt te worden, een belangrijk doel van de monitoring. De in dit rapport gepresenteerde metingen en analyses dragen hier al wel aan bij.

In de volgende paragraaf wordt de analyse van de morfologie van de gehele Roggenplaat in de T0 en T1 situatie gepresenteerd. In de twee daar op volgende paragrafen wordt in meer detail ingegaan op de ontwikkeling van de suppletie-elementen en de afwateringsgeulen. Vervolgens komt de ontwikkeling in droogvalduur, de sedimentsamenstelling en de stroom- en golfmetingen aan bod.

\subsubsection{Recente hoogteontwikkeling Roggenplaat}

\subsubsection{Methode}


In de T0/T1 periode zijn hoogtekaarten verkregen middels laseraltimetrie (ofwel LiDAR) in 2016, 2018, 2019 en tweemaal in 2020. De hoogtekaart uit 2016 voldoet niet aan de kwaliteitseisen en wordt hier buiten beschouwing gelaten. Een gedetailleerde beschrijving van de methode staat in Walles et al. (2021).

\subsubsection{Resultaten}

In Figuur 6-1 zijn de LiDAR data van 2018, 2019 en 2020 gepresenteerd en vergeleken. Omdat er slechts één jaar tussen de metingen van 2018 en 2019 zit en de ontwikkelingen op de Roggenplaat relatief gradueel verlopen (Hoofdstuk 4 in Walles et al. 2021), zijn de verschillen tussen 2018 en 2019 zeer beperkt. Dit komt ook tot uitdrukking in de zeer vergelijkbare hypsometrische curves. Het grootste verschil tussen de hoogtekaarten is de aanwezigheid van de suppletie-elementen in de LiDAR opnamen vanaf 2020. De aanwezigheid van deze elementen resulteerde in een substantiële verandering van de hypsometrische curves. Bijvoorbeeld, het areaal met een droogvalduur van meer dan $50 \%$ is tussen april 2019 en februari 2020 met ongeveer 130 ha toegenomen. De hypsometrische curve van oktober 2020 toont een totaal areaal van de Roggenplaat (het areaal bij gemiddeld laagwater) dat 90 ha kleiner is dan het areaal in februari 2020. Dit is het gevolg van het ontbreken van een substantieel deel van de Roggenplaat in de metingen van oktober 2020, onder meer rond de noordelijke punt van de plaat (Figuur 6-1). Dit is dus geen morfologische verandering. De dekking van de suppletie-elementen $1 \mathrm{t} / \mathrm{m} 7$ (Figuur 4-1) is wel bijna volledig in deze LiDAR opname.
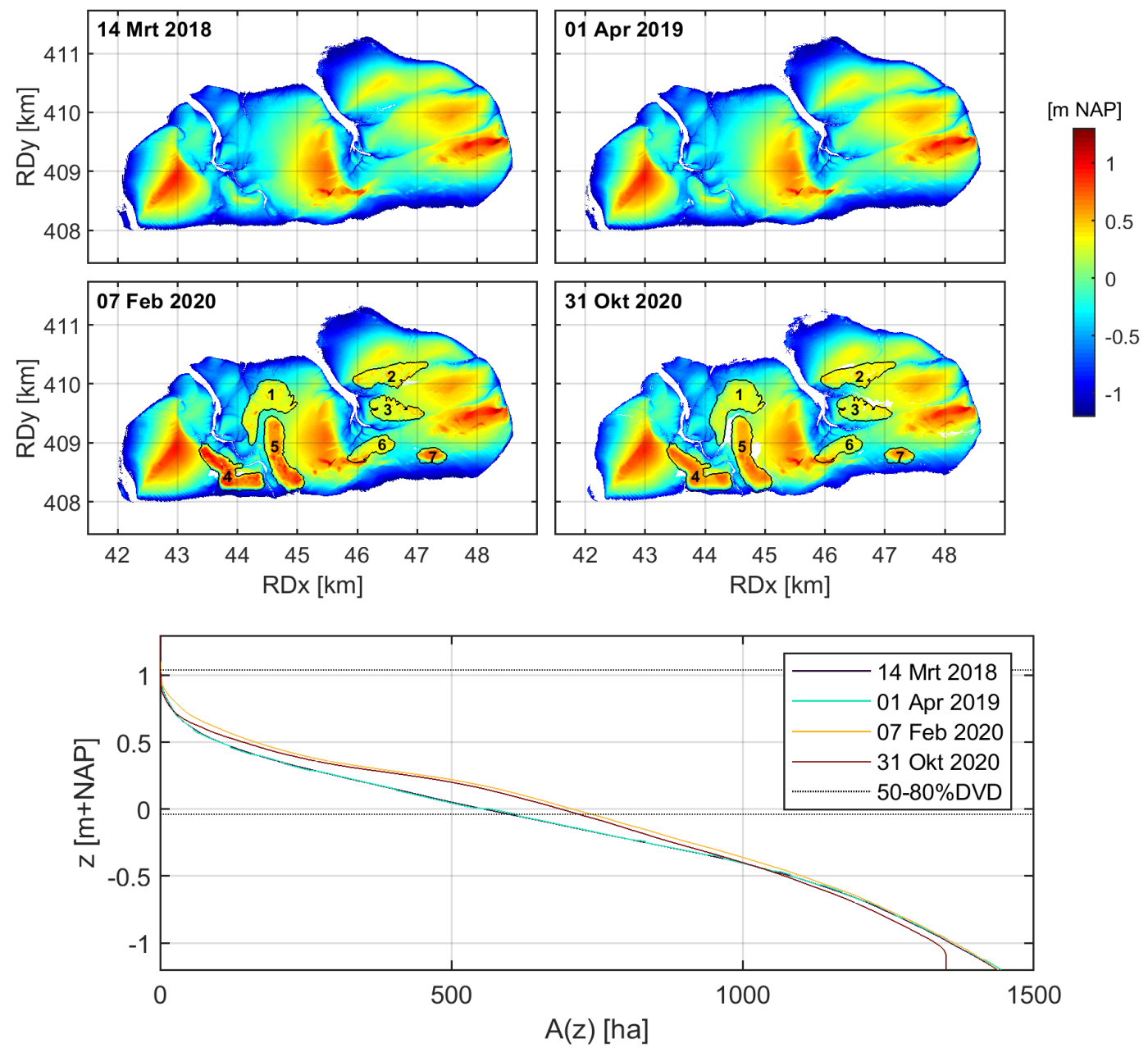

Figuur 6-1. LiDAR data van de Roggenplaat van 2018, 2019 en 2020. Hoogtekaarten (boven) en hypsometrische curves (onder) zijn weergeven. De contouren en nummering van de suppletie-elementen zijn in de hoogtekaarten van 2020 aangegeven. De ondergrens van de hypsometrische curves is gemiddeld laagwater, de bovengrens is gemiddeld hoogwater. 
De veranderingen in morfologie zijn nader onderzocht met verschilkaarten (Figuur 6-2). Op de verschilkaart tussen 2018 en 2019 (voor suppleren) zijn morfologische ontwikkelingen zichtbaar die de nauwkeurigheid van de LiDAR data overschrijden $( \pm 15$ $\mathrm{cm}$ ). Er zijn in het zuidoosten van het Middengeultje tientallen centimeters aan veranderingen zichtbaar die duiden op een migratie van een van de aftakkingen van het Middengeultje (omcirkeld in Figuur 6-2). Deze veranderingen zijn in Paragraaf 6.2.4 nader onderzocht met de Multibeam data. Verder migreren de bodemvormen op de Roggenplaat naar het noordoosten tussen 2018 en 2019 (gemarkeerd met de pijlen in Figuur 6-2). Deze migratie is in lijn met de ontwikkeling zoals in de afgelopen decennia waargenomen (Hoofdstuk 4 in Walles et al. 2021) en is ook in de 2020 metingen (na aanleg van de suppleties) zichtbaar.

In de verschilkaart tussen april 2019 en februari 2020 domineren de zeven suppletieelementen. De toename in bodemhoogte overschrijdt de kleurschaal substantieel. In de volgende paragraaf is de dikte van de suppletie-elementen nader geanalyseerd. De verschilkaart tussen februari en oktober 2020 geeft een indicatie van de morfologische ontwikkeling van de suppletie-elementen. Alle suppletie-elementen zijn in hoogte afgenomen. Met name de zuidelijke suppletie-elementen 4, 5 en 7 liggen in de opname van oktober 2020 enkele tientallen centimeters lager. Ten noordoosten van element 1 , 4, 5 en 7 is sedimentatie zichtbaar, al lijkt dit minder dan de erosie van deze elementen. In hoeverre de suppletie-elementen lager liggen door erosie, zetting van de ondergrond en/of meetfouten wordt in het vervolg van het project onderzocht. 

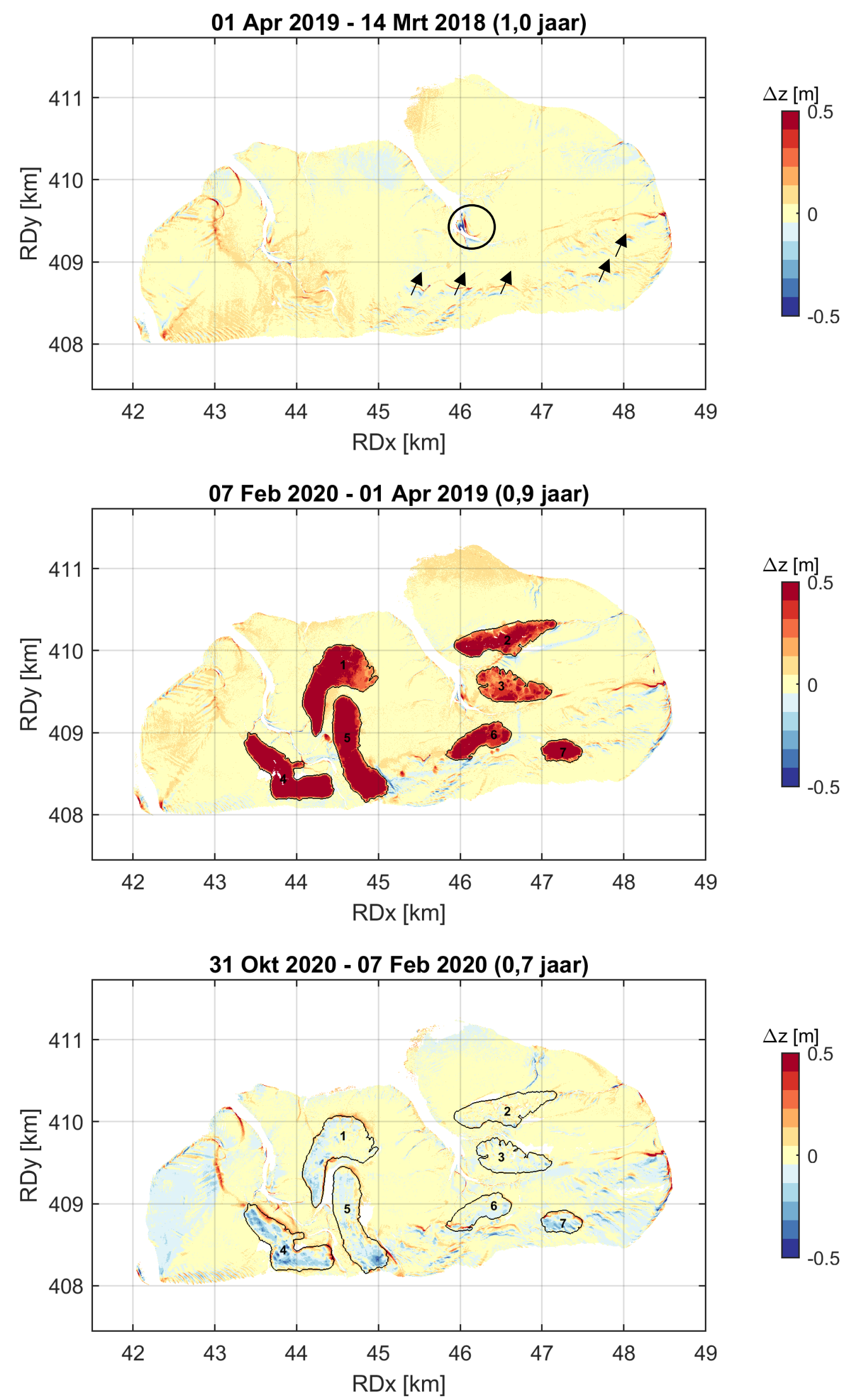

Figuur 6-2. Verschilkaarten van de LiDAR data van de Roggenplaat tussen april 2019 en maart 2018 (bovenste kaart), tussen februari 2020 en april 2019 (middelste kaart), en tussen oktober 2020 en februari 2020 (onderste kaart). In de eerste verschilkaart (2019-2018) tonen de pijlen de autonome migratierichting van de bodemvormen en de cirkel de veranderingen in het zuidoosten van het Middengeultje. De contouren en nummering van de suppletie-elementen zijn in de verschilkaarten met data van 2020 aangegeven. In Figuur 6-16 zijn de ontwikkelingen in het zuidoosten van het Middengeultje in meer detail (en uitvergroot) weergeven. 
Uit de verschilkaart tussen april 2019 (voor aanleg van de suppleties) en februari 2020 (na aanleg) is af te leiden dat geulvorming plaatsvindt, onder andere aan de zuidoostzijde van suppletie-element 5 en aan de zuidzijde van suppletie-element 2 (Figuur 6-3). Dit is ook vastgesteld tijdens veldbezoeken. Deze specifieke erosietrends zijn niet (duidelijk) zichtbaar in de verschilkaart tussen april en oktober 2020 (Figuur 6-2). De LiDAR metingen in de komende jaren zijn noodzakelijk om de geulvorming over de Roggenplaat goed te kunnen beoordelen.

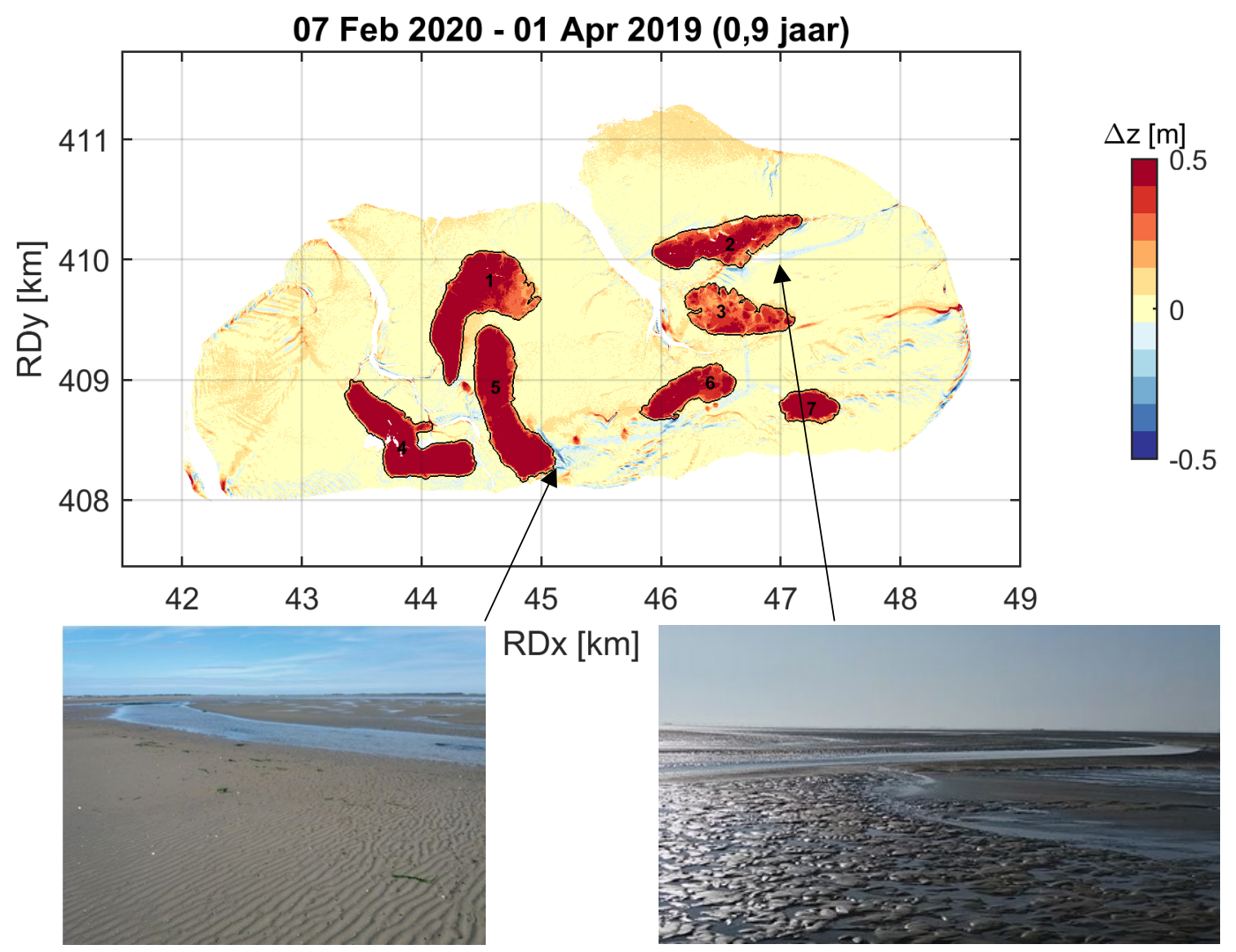

Figuur 6-3. Geulvorming in de maanden na aanleg van de suppleties zichtbaar in de foto's (7 juli 2020) en op de verschilkaart.

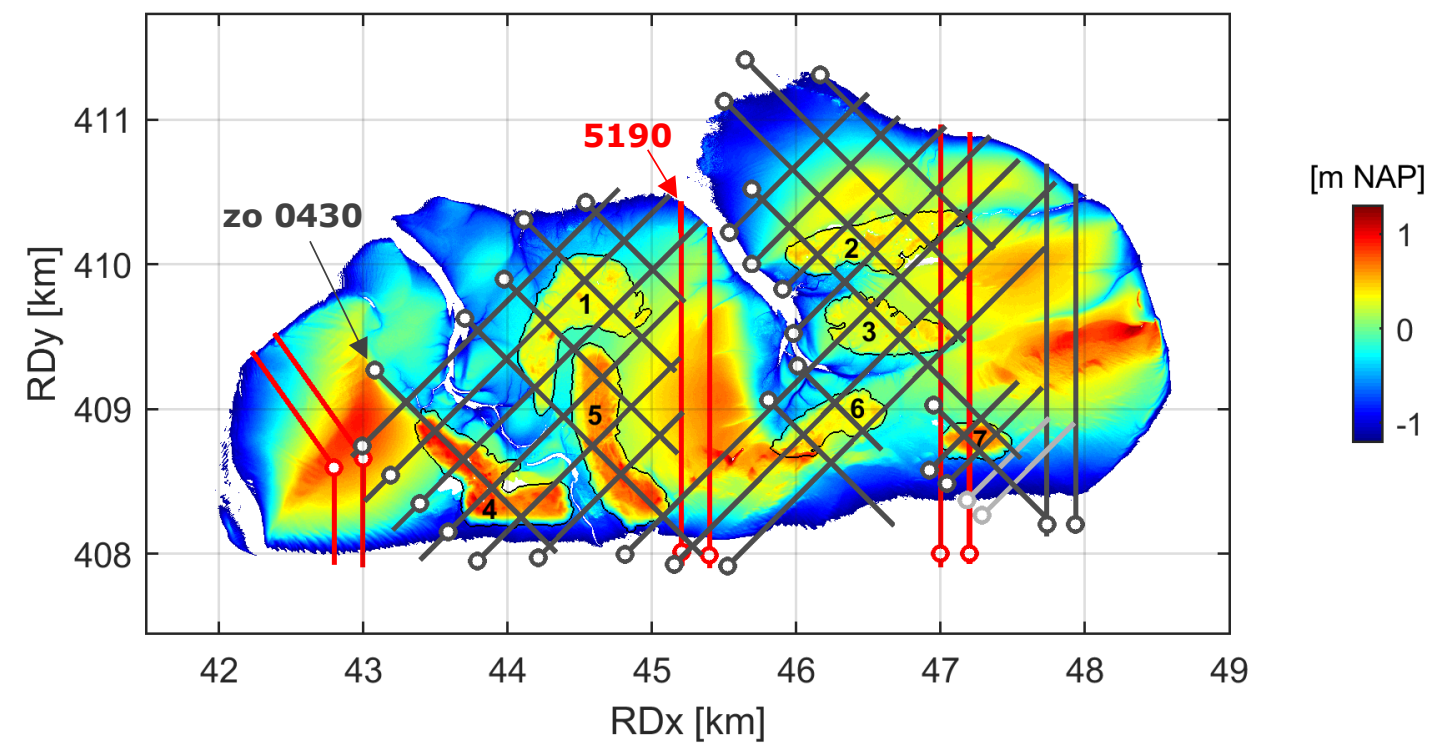

Figuur 6-4. Reguliere RTK raaien (rood) en aanvullende RTK raaien (donkergrijs) op de Roggenplaat. De cirkels geven het nulpunt van elke raai aan. Op de achtergrond zijn de LiDAR data van februari 2020 weergeven (boven laagwater). De contouren en de nummering van de suppletie-elementen is aangegeven. 
In Figuur 6-5 is de ontwikkeling langs twee van de RTK-dGPS raaien (5190 en zo 0430) weergeven. Raai 5190 ligt ongeveer $100 \mathrm{~m}$ ten oosten van suppletie-element 5 en werd al voor 2015 gemeten. De metingen in 2020 (Figuur 6-5) geven in hoofdlijnen een continuering van de lange-termijn ontwikkelingen aan met de meeste erosie in het zuiden (links in het profiel) en een migratie van de bodemvormen naar het noorden (naar rechts in het profiel). In deze raai is sinds maart 2020, de eerste meting na aanleg van de suppletie-elementen, een lokale verlaging van ongeveer $40 \mathrm{~cm}$ zichtbaar (omcirkeld in Figuur 6-5). Dit komt overeen met de geulvorming aan de zuidoostzijde van suppletie 5, gemarkeerd in Figuur 6-3. Hoewel deze nieuw gevormde afwateringsgeul in 2020 naar het noorden migreerde $(\sim 50 \mathrm{~m})$ is de diepte van deze afwateringsgeul in alle metingen in 2020 ongeveer $40 \mathrm{~cm}$ (ten opzichte van de lokale plaathoogte).

Raai zo 0430 loopt over suppletie-element 4. In de LiDAR data is dit een van de elementen met de grootste afname in hoogte na aanleg (lokaal enkele tientallen centimeters). De RTK metingen tonen dat dit element langs raai zo 0430 ongeveer 10 $\mathrm{cm}$ in hoogte is afgenomen. De grootste hoogteverandering trad op tussen mei en september 2020, al zat er tussen deze twee metingen ook de langste duur. Aan de zuidoostzijde en noordwestzijde van dit suppletie-element is in deze raai geen substantiële sedimentatie zichtbaar. Dit is in lijn met de LiDAR data van 2020 (Figuur 6-2), waarin de sedimentatie rond element 4 hoofzakelijk ten noordoosten van dit element optrad.
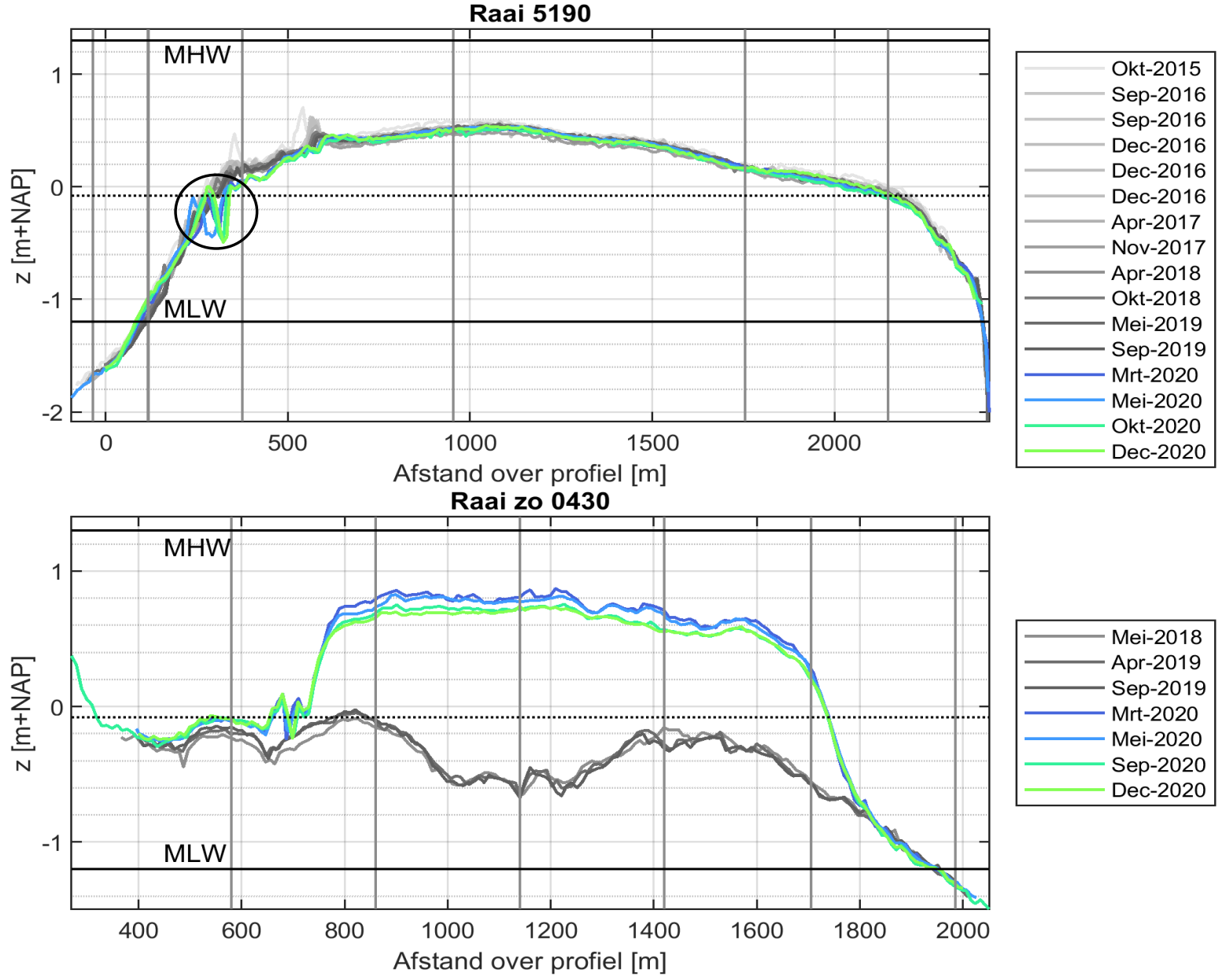

Figuur 6-5. Bodemligging langs RTK raaien 5190 en zo 0430. De afstand neemt voor de eerste raai toe in noordelijke richting en voor de tweede raai in zuidoostelijke richting. De gemiddeld laagwater- (MLW) en hoogwaterstanden (MHW) zijn aangegeven, net als de gemiddelde waterstand (stippellijn). Zie Figuur 6-4 voor de ligging van de raaien. De TO situatie is in grijstinten gepresenteerd. De vorming van een afwateringsgeul dwars over raai 5190 is omcirkeld. 
In Figuur 6-6 zijn de veranderingen in bodemhoogte, gemeten langs de RTK raaien, ruimtelijk weergeven. Om dit mogelijk te maken zijn alle raaien in segmenten van $50 \mathrm{~m}$ opgedeeld. De afmeting van $50 \mathrm{~m}$ is groot genoeg voor voldoende metingen binnen elk segment en klein genoeg voor het weergeven van de ruimtelijke variatie in ontwikkeling over de morfologische elementen. Voor elk deel van de raaien is de gemiddelde bodemhoogte bepaald voor alle metingen. In Figuur 6-6 zijn de veranderingen in bodemhoogte weergeven van maart 2020 tot november/december 2020. De raaien zijn in maart in 4 dagen gemeten en in november/december in 19 dagen.

Globaal gezien onderbouwen de raaimetingen (Figuur 6-6) de patronen in de verschilkaart van de LiDAR data van februari tot oktober 2020 (Figuur 6-2). De hogere nauwkeurigheid van de RTK-dGPS raaien $( \pm 3 \mathrm{~cm})$ ten opzichte van de LiDAR data $( \pm 15$ $\mathrm{cm}$ ) maakt een analyse van kleinere bodemveranderingen mogelijk, vandaar de meer gedetailleerde kleurschaal in Figuur 6-6 dan in Figuur 6-2. Bijvoorbeeld, suppletieelement 7 toont een daling in hoogte en sedimentatie ten noorden van dit element. Ook de raaimetingen laten zien dat elementen 4, 5 en 7 de grootste lokale daling in bodemhoogte ondervonden. Direct ten noordwesten van suppletie-element 5 ontbreekt er data in de LiDAR verschilkaart van februari tot oktober 2020. In de raaimetingen is hier lokaal erosie zichtbaar. Bij afgaand water blijft tussen suppletie-elementen 1 en 5 lokaal water staan. Dat verklaart ook het gebrek aan LiDAR data op deze plek.

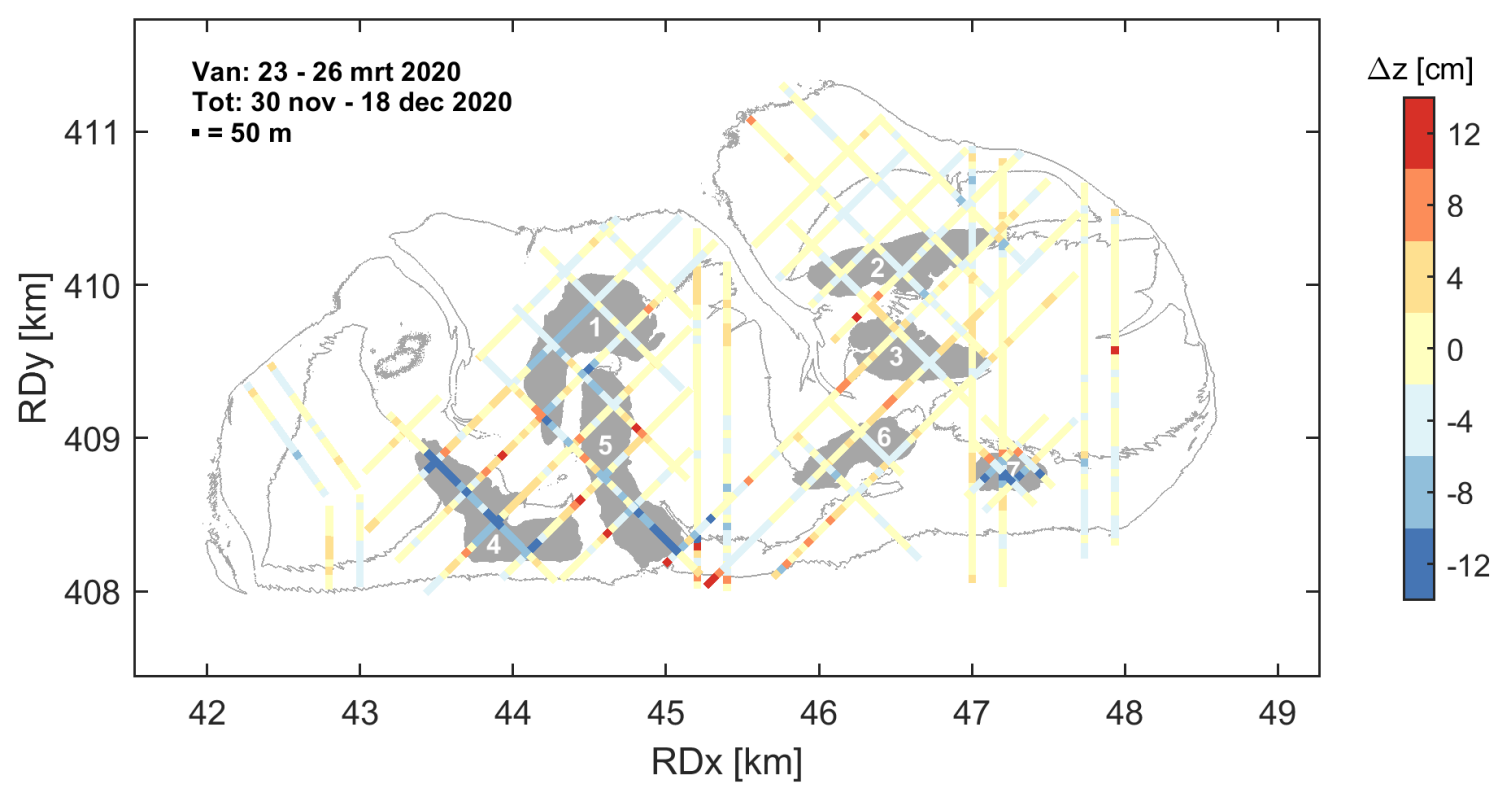

Figuur 6-6. Verschil in bodemhoogte tussen maart 2020 (eerste meting na aanleg) en november/december 2020 (laatste meting van T1) op basis van alle RTK raaien, geprojecteerd op een bovenaanzicht van de Roggenplaat. De RTK raaien zijn opgedeeld in segmenten van $50 \mathrm{~m}$. Binnen elk segment is de gemiddelde bodemligging van het deel van de raai binnen het segment bepaald. De contouren van de Roggenplaat bij gemiddeld laagwater en gemiddeld water en de ingevulde contouren van de suppletie-elementen zijn, op basis van de LiDAR data van februari 2020, weergeven.

In het vervolg van het project zal, aan de hand van nieuwe raai- en LiDAR metingen, de ontwikkeling van de Roggenplaat nader worden gevolgd. Het aantal metingen na aanleg van de suppletie-elementen (twee LiDAR opnamen en vier raaiopnamen) is nog te beperkt voor trendanalyses. Ook zal onderzocht worden hoe de raai- en LiDAR metingen geïntegreerd kunnen worden om de waarde van beide individuele datasets te versterken, zowel ruimtelijk als temporeel. 


\subsubsection{Ontwikkeling suppletie-elementen}

\subsubsection{Methode}

Voor een robuuste bepaling van de ontwikkeling van de suppletie-elementen is een precieze definitie van de contouren van de elementen essentieel. De contouren zijn in deze studie op de volgende manier vastgesteld. Contourlijnen zijn getrokken rondom de suppletie-elementen waarvoor de toename in bodemhoogte tussen april 2019 (voor aanleg) en februari 2020 (na aanleg) meer dan $20 \mathrm{~cm}$ betrof (overschrijdt ruim de meetonnauwkeurigheden). Ook de priming vakken zijn bij de contouren betrokken (onderdeel van suppletie-element 2) ondanks dat de toename in bodemhoogte hier lokaal minder dan $20 \mathrm{~cm}$ was. Vervolgens zijn deze contourlijnen met $10 \mathrm{~m}$ - de horizontale afstand corresponderend bij $20 \mathrm{~cm}$ hoogte verschil bij een helling van 1 op 50 (beoogde aanleg helling) - naar buiten toe uitgebreid. Dit geeft een goede benadering van de contouren van de voet van de suppleties die niet gedomineerd wordt door meetfouten in de LiDAR data of beïnvloed wordt door centimeters aan autonome ontwikkeling.

\subsubsection{Resultaten}

In de LiDAR hoogtekaarten van 2020 (Figuur 6-1), waar tevens de nummering van de elementen in is aangegeven, zijn de aangebrachte suppletie-elementen duidelijk aanwezig. In de voorgaande paragraaf is de morfologische ontwikkeling, samen met de ontwikkeling van de plaat, al enigszins aan bod gekomen. In deze paragraaf wordt de morfologie van de suppletie-elementen nader geanalyseerd. De hier gepresenteerde resultaten zijn de eerste resultaten. Zoals al vermeld is de ontwikkeling van de morfologie en de onderliggende oorzaken nog in onderzoek.

Suppletie-elementen 4, 5 en 7 zijn de hoogste en steken tot 1 meter boven NAP uit. De overige elementen zijn wat lager en liggen voor het grootste deel enkele decimeters boven NAP en dus enkele decimeters boven de $50 \%$ droogvalduur klasse. Dit is goed zichtbaar in de hypsometrische curves van de individuele suppletie-elementen van februari 2020 (Figuur 6-7), 1,5 maand na voltooiing van het laatste suppletie-element.

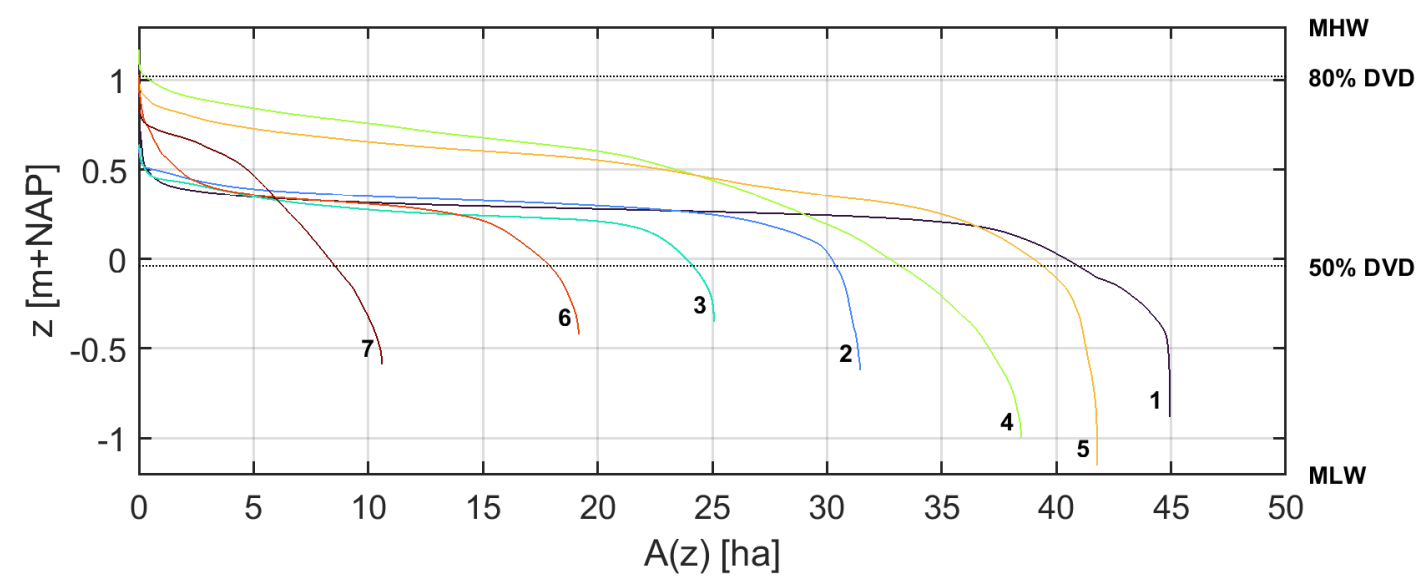

Figuur 6-7. Hypsometrische curves van de individuele suppletie-elementen $1 \mathrm{t} / \mathrm{m} 7$ op basis van de LiDAR data van de Roggenplaat van februari 2020 (eerste opname na aanleg).

De dikte van de suppleties (het verschil tussen de hoogteligging in april 2019 en februari 2020) varieert tussen de elementen en ook binnen de elementen (Figuur 6-8). De maximaal aangebrachte laagdikte is $1,9 \mathrm{~m}$ op suppletie-element 4 . Op de aan de 
zuidkant gelegen suppleties 4,5 en 7 is een dikkere sedimentlaag aangebracht dan op suppleties 1, 2 en 3 gelegen aan de noordkant van de Roggenplaat, zie ook Tabel 1.

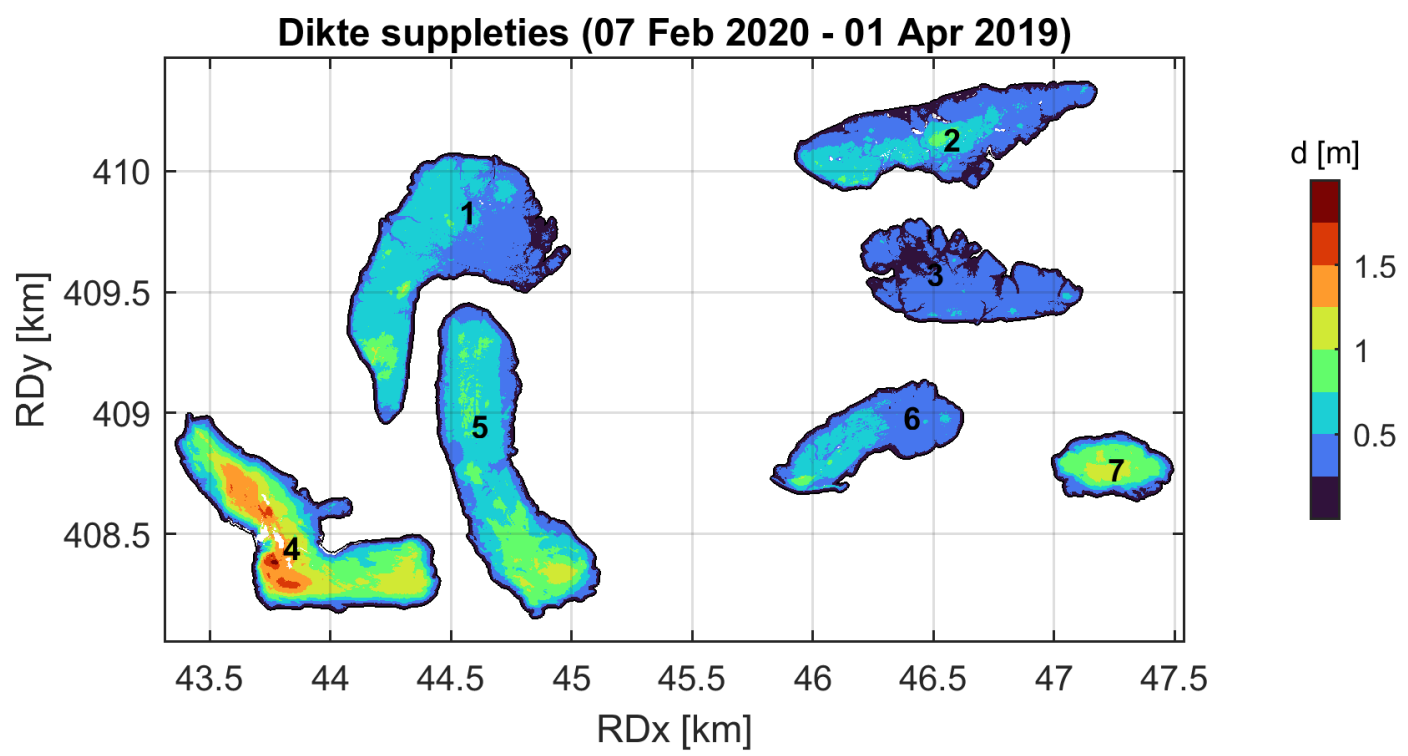

Figuur 6-8. Dikte van de zeven suppletie-elementen, gebaseerd op de LiDAR opnamen van 1 april 2019 (voor aanleg) en 7 februari 2020 (na aanleg). De nummering van de elementen is aangegeven.

In Tabel 1 is de hoeveelheid gesuppleerd sediment gepresenteerd, zoals bepaald door Boskalis na voltooiing van de suppletiewerken. Het is zinvol de hoeveelheid sediment in de suppletie-elementen ook te bepalen aan de hand van de LiDAR data. Dit biedt de kans de ontwikkeling van de suppletie-elementen in de komende jaren te analyseren aan de hand van de nog volgende LiDAR metingen.

Op basis van de suppletiecontouren en de LiDAR opnamen van april 2019 (voor aanleg) en februari 2020 (na aanleg) is het areaal, volume en de gemiddelde dikte van de suppletie-elementen in februari 2020 bepaald, zie Tabel 3. Deze hoeveelheden wijken iets af ten opzichte van Tabel 1 . Het totaalvolume van de suppleties ligt bijvoorbeeld $2 \%$ lager dan de waarde zoals bepaald door Boskalis in Tabel 1. Hier liggen een aantal mogelijke oorzaken aan ten grondslag. Ten eerste zijn de hoeveelheden in Tabel 3 enkele maanden later gemeten. De morfologie van de suppletie-elementen is dan al enigszins ontwikkeld. Ten tweede kunnen kleine verschillen in de contouren van de suppleties ook leiden tot kleine verschillen in de kentallen van de suppleties. Ten derde kunnen verschillen ook ontstaan door meetfouten. Ter illustratie, een gemiddelde netto meetfout in de verschilkaart van $1 \mathrm{~cm}$ leidt bij een areaal van 211 ha (het gesuppleerde areaal) tot een meetfout van $21.100 \mathrm{~m}^{3}$ ( $2 \%$ van het totale gesuppleerde volume).

Mede door de mogelijke invloed van meetfouten zullen aanvullende LiDAR metingen noodzakelijk zijn om de ontwikkeling van de suppleties robuust te kunnen vaststellen. Ook zal een validatie en/of een combinatie met de metingen van de RTK raaien de nauwkeurigheid bepaling van de morfologische ontwikkelingen kunnen bevorderen. Ondanks deze kanttekeningen, geeft Tabel 3 al wel een eerste indruk van de ontwikkeling van de suppletie-elementen (van februari naar oktober 2020). Bijvoorbeeld, het noordelijke suppletie-element 2 is een stuk minder veranderlijk (verandering in gemiddelde dikte $\approx 0 \mathrm{~cm}$ ) dan de zuidelijke elementen 4, 5 en 7 (5-7 $\mathrm{cm}$ afname in gemiddelde dikte/hoogte). Voor deze elementen is in de ontwerpfase rekening gehouden met meer erosie door een grotere blootstelling aan golven (van der Werf et al., 2016b). Vooral elementen 4 en 5 zijn uitgevoerd met een substantieel hogere gemiddelde bodemligging $(13 \mathrm{~cm}$ hoger dan het gemiddelde van alle elementen; zie 
Tabel 3 en Figuur 6-7). Of deze zuidelijke elementen daadwerkelijk meer eroderen of dat deze elementen onderhevig zijn aan meer bodemdaling door de grotere laagdikte (Tabel 3) moet nog onderzocht worden. Ook moet nog blijken of de ontwikkeling van de suppleties geleidelijk verloopt of dat bijvoorbeeld (extreme) stormen de veranderingen domineren.

Tabel 3 Kentallen van de suppletie-elementen op basis van de LiDAR data. Het oppervlakte (A), volume $(V)$, de gemiddelde bodemligging $(h)$ en gemiddelde dikte (d) zijn bepaald als het verschil tussen april 2019 en februari 2020. De ontwikkeling in volume $(\Delta \mathrm{V})$ en gemiddelde dikte/hoogte $(\Delta d)$ van de elementen is bepaald als het verschil tussen februari en oktober 2020. Eventuele gaten in de LiDAR data zijn middels ruimtelijke interpolatie opgevuld. De nauwkeurigheid van deze resultaten wordt nog onderzocht.

\begin{tabular}{|c|c|c|c|c|c|c|}
\hline $\begin{array}{l}\text { Suppletie- } \\
\text { element }\end{array}$ & $\begin{array}{c}\text { A [ha] } \\
\text { feb } 2020\end{array}$ & $\begin{array}{l}V\left[10^{3} \mathrm{~m}^{3}\right] \\
\text { feb } 2020\end{array}$ & $\begin{array}{c}\Delta V\left[10^{3} m^{3} \text { en } \%\right] \\
\text { feb - okt } 2020\end{array}$ & $\begin{array}{c}h[m+N A P] \\
\text { feb } 2020\end{array}$ & $\begin{array}{c}d[\mathrm{~cm}] \\
\text { feb } 2020\end{array}$ & $\begin{array}{c}\Delta d[\mathrm{~cm}] \\
\text { feb - okt } 2020\end{array}$ \\
\hline 1 & 45 & 210 & $-16(-8 \%)$ & $\mathrm{NAP}+0,23$ & 47 & -4 \\
\hline 2 & 31 & 127 & $0(0 \%)$ & $\mathrm{NAP}+0,30$ & 40 & 0 \\
\hline 3 & 25 & 74 & $-8(-10 \%)$ & $\mathrm{NAP}+0,26$ & 30 & -3 \\
\hline 4 & 38 & 311 & $-24(-8 \%)$ & $\mathrm{NAP}+0,47$ & 81 & -6 \\
\hline 5 & 42 & 244 & $-22(-9 \%)$ & $\mathrm{NAP}+0,47$ & 58 & -5 \\
\hline 6 & 19 & 80 & $-5(-6 \%)$ & $\mathrm{NAP}+0,29$ & 42 & -3 \\
\hline 7 & 11 & 68 & $-7(-11 \%)$ & $\mathrm{NAP}+0,33$ & 64 & -7 \\
\hline Totaal & 211 & 1115 & $-82(-7 \%)$ & $\mathrm{NAP}+0,34$ & 53 & -4 \\
\hline
\end{tabular}

\subsubsection{Golven en sediment dynamiek}

\subsubsection{Methode}

Op een aantal locaties op de Roggenplaat zijn SED sensoren geplaatst na aanleg van de suppleties (Figuur 6-9). SED sensoren (Surface Elevation Dynamics sensoren) meten continu veranderingen in hoogte en kunnen inzicht verschaffen onder welke (weers)omstandigheden veranderingen in bodemhoogte optreden ( $\mathrm{Hu}$ et al. 2015). Inmiddels bestaat er 2 versies van deze SED-sensoren: Optische en Akoestische. De Optische sensoren (eerste meetprincipe) meten alleen zonder bovenstaand water en hebben om de $2 \mathrm{~mm}$ een sensor die de lichtinval meet. Met een meetinterval van 30 minuten wordt een zeer gedetailleerde verandering van de bodemhoogte gemeten. De akoestische sensoren (verbeterd instrument) meten alleen onder water en geven een akoestische puls die weer door de sensor wordt opgevangen. Hierdoor wordt er nog nauwkeuriger gemeten, mede door het meetinterval van vijf minuten. Op deze manier vindt de meting plaats wanneer er daadwerkelijke verandering van bodemhoogte optreedt. Daarnaast heeft deze dit apparaatje ook een druksensor, waardoor golven en waterhoogte gemeten wordt 


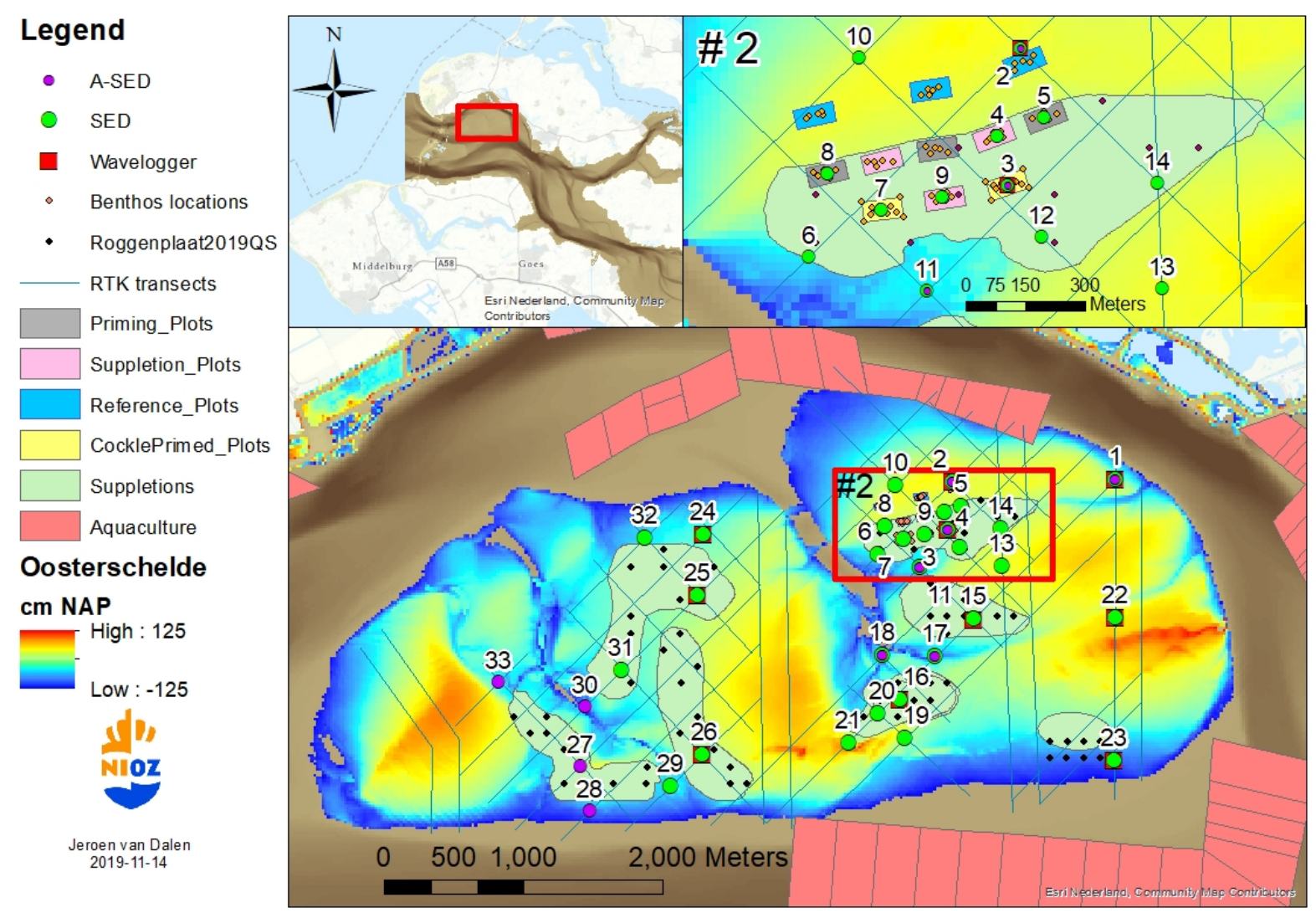

Figuur 6-9. Locatie van SED sensoren, akoestische SED sensoren (A-SED) en waveloggers op de Roggenplaat. Op suppletie 2 de verschillende plots met een kleur aangegeven: Grijs $=$ geprimed met toplaag omgevingssediment, Roze = 'kale' suppletie, Blauw $=$ Referentie/onverstoord gebied en Geel = 'kale' suppletie geprimed met individuele kokkels. Daarnaast zijn alle punten waar Benthos en de veldscreening (QS) genomen wordt weergegeven.

\subsubsection{Resultaten golven}

Door diverse redenen zijn er verschillende sensoren uitgevallen of verloren, daarnaast hebben sommige niet de gehele periode gemeten (Tabel 4).

Tabel 4 Overzicht met daadwerkelijke meetperiodes en verlies van sensoren.

\begin{tabular}{|l|l|l|l|}
\hline Type & Issue & Aantal & Data tot \\
\hline \hline ASED & Ok & 7 & $2020-09$ \\
\hline ASED & Weg & 2 & $\mathrm{X}$ \\
\hline SED & Ok & 15 & $2020-06$ \\
\hline SED & Verdronken & 7 & $2020-04$ \\
\hline Wavelogger & Ok & 7 & $2020-12$ \\
\hline Wavelogger & No data & 1 & $\mathrm{X}$ \\
\hline
\end{tabular}

Allerlei omstandigheden (covid-beperkingen NIOZ + vorst) hebben het moeilijk gemaakt de sensoren van de Roggenplaat terug te krijgen. Dit lukte uiteindelijk pas een week voor deze rapportage, wat beperkte tijd bood om de data te verwerken en analyseren. De eerste ruwe analyse (Figuur 6-10) toont dat er significant hogere golven aan de rand van de Roggenplaat (Punt 1 Figuur 6-9) voorkomen, dit in tegenstelling tot midden op de plaat (punt 22) en bovenop één van de suppleties (punt 15). Opvallend is echter dat punt 1 in de luwte van de plaat ligt. De vraag is dan ook wat de oorzaak is van deze 
golven. Dit vergt nadere analyse, en vergelijking met golfmetingen aan de zuidrand (punt 28 in Figuur 6-13) van de plaat (moet nog gebeuren).

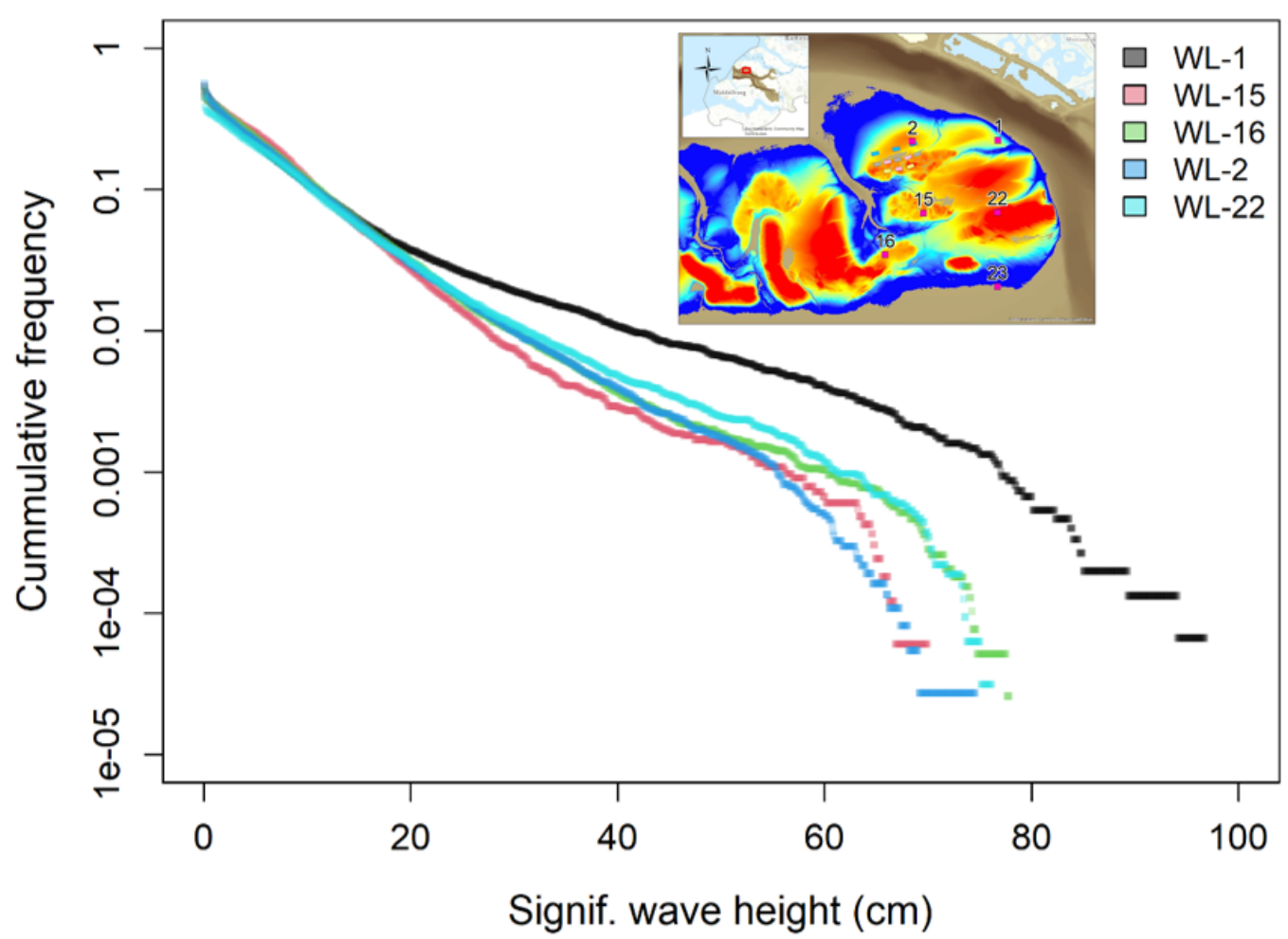

Figuur 6-10 Voorkomen van golfhoogtes op aangegeven punten tijdens de meetperiode van november 2019 tot december 2020.

Tijdens stormen worden relatief grote golven gemeten ten opzichte van de beperkte waterdiepte (Figuur 6-11). Een meer ruimtelijke analyse, met orbitaal snelheden en mogelijke consequenties voor bodemerosie, moet nog worden uitgevoerd.

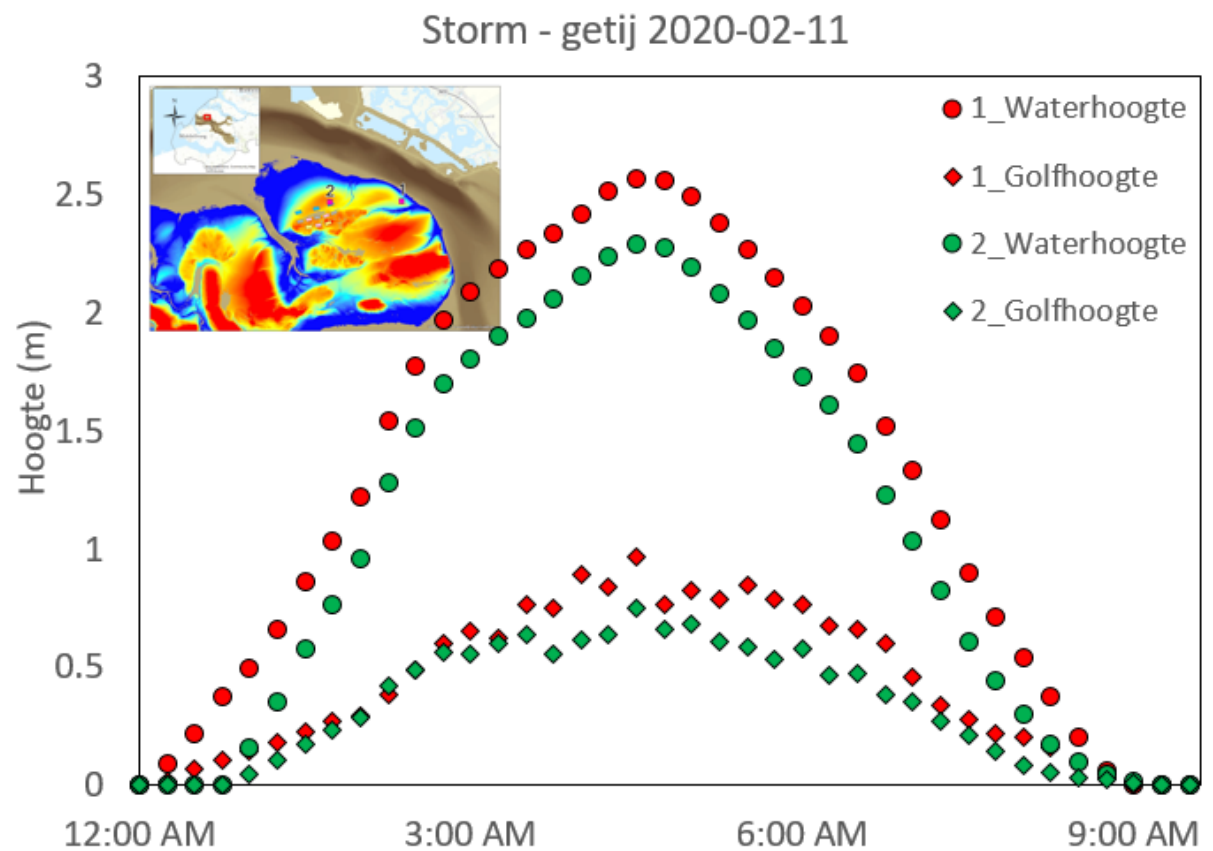

Figuur 6-11 Waterhoogte en significante golfhoogte tijdens een storm op 11 februari 2020 op sensor punt 1 en 2, zie Figuur 6-9. 


\subsubsection{Resultaten bodemhoogte}

\section{Optische SED's}

De sensor op kokkelvak 1 (zie Figuur 6-47) van suppletie 2 (sensor punt 7) laat een vrij stabiele bodemhoogte zien (Figuur 6-12). De trend is $+/-5 \mathrm{~mm}$ erosie in de eerste zes maanden na aanleg. In het bijbehorende referentiegebied (sensor 10) is een lichte vorm van sedimentatie van februari zichtbaar. Dit kan verklaarbaar zijn door het uitwaaieren van de suppleties, op punt 29 is ook duidelijk sedimentatie waarneembaar. Hier is de suppletie later aangebracht, maar vrijwel direct na aanleg is er naast de suppletie sedimentatie van enkele centimeters te zien.

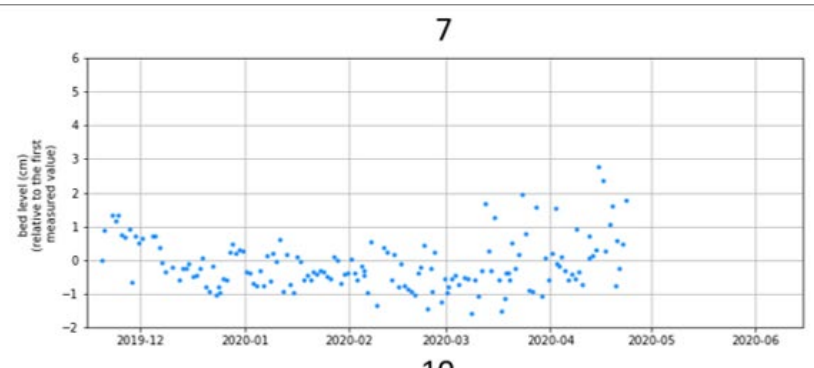

10

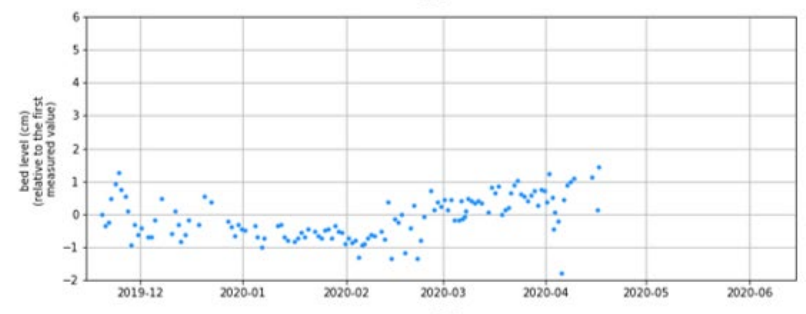

29
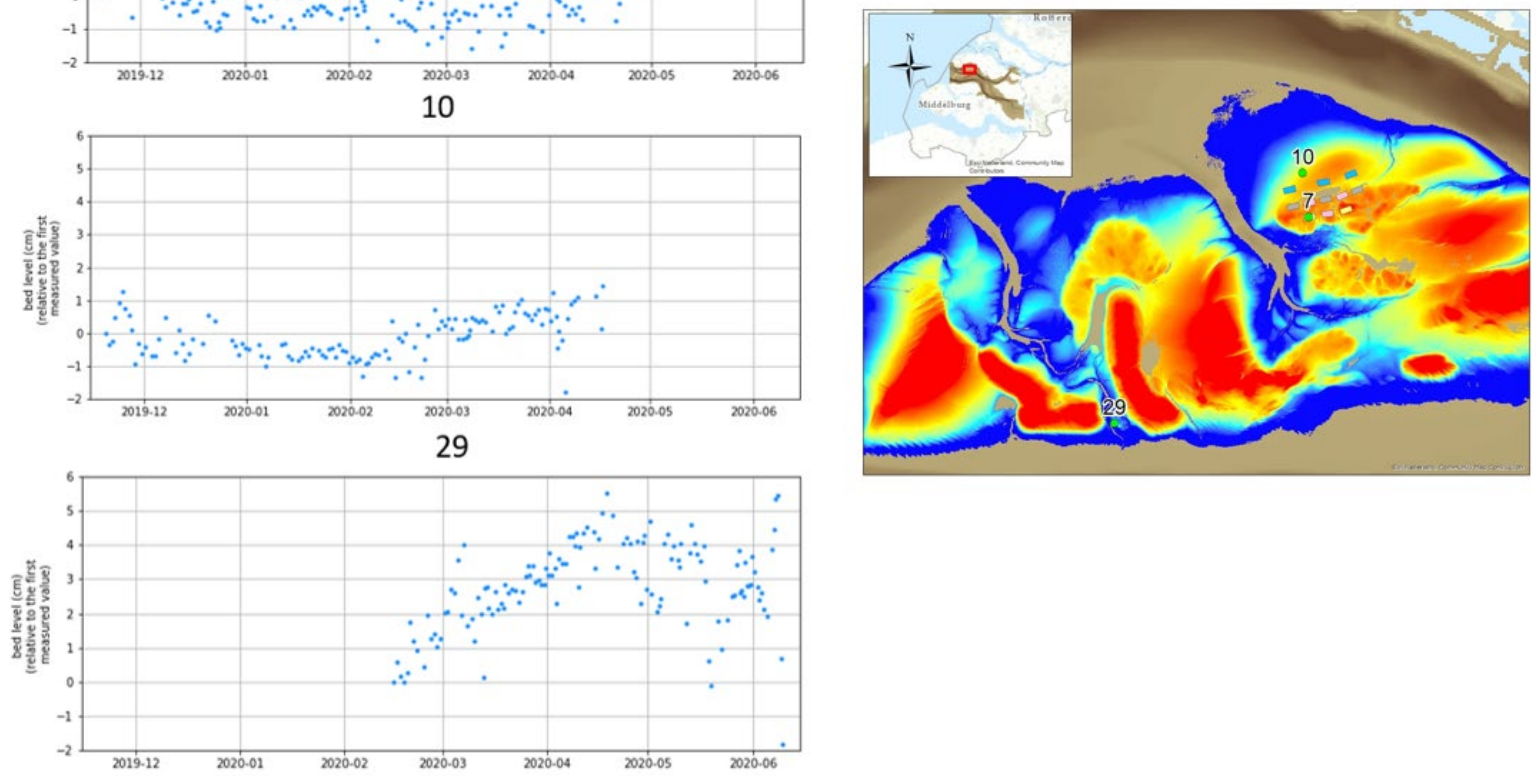

Figuur 6-12 Optische SED-resultaten van sensor punten 10, 7 en 29.

\section{Akoestische SED's}

Aan de Oostkant van de Roggenplaat, op en rond suppletie 2, is de bodemhoogte vrij stabiel. Dit in tegenstelling tot de suppleties aan de Westkant; hier is vrij direct na aanleg van suppletie 4 een erosie van ongeveer 15 centimeter te zien (punt 27). Mogelijk verklaart het wegspoelen van zand op deze locatie de ophoging van het naastgelegen gebieden en de nabij gelegen geul (punt 30) (Figuur 6-13). 


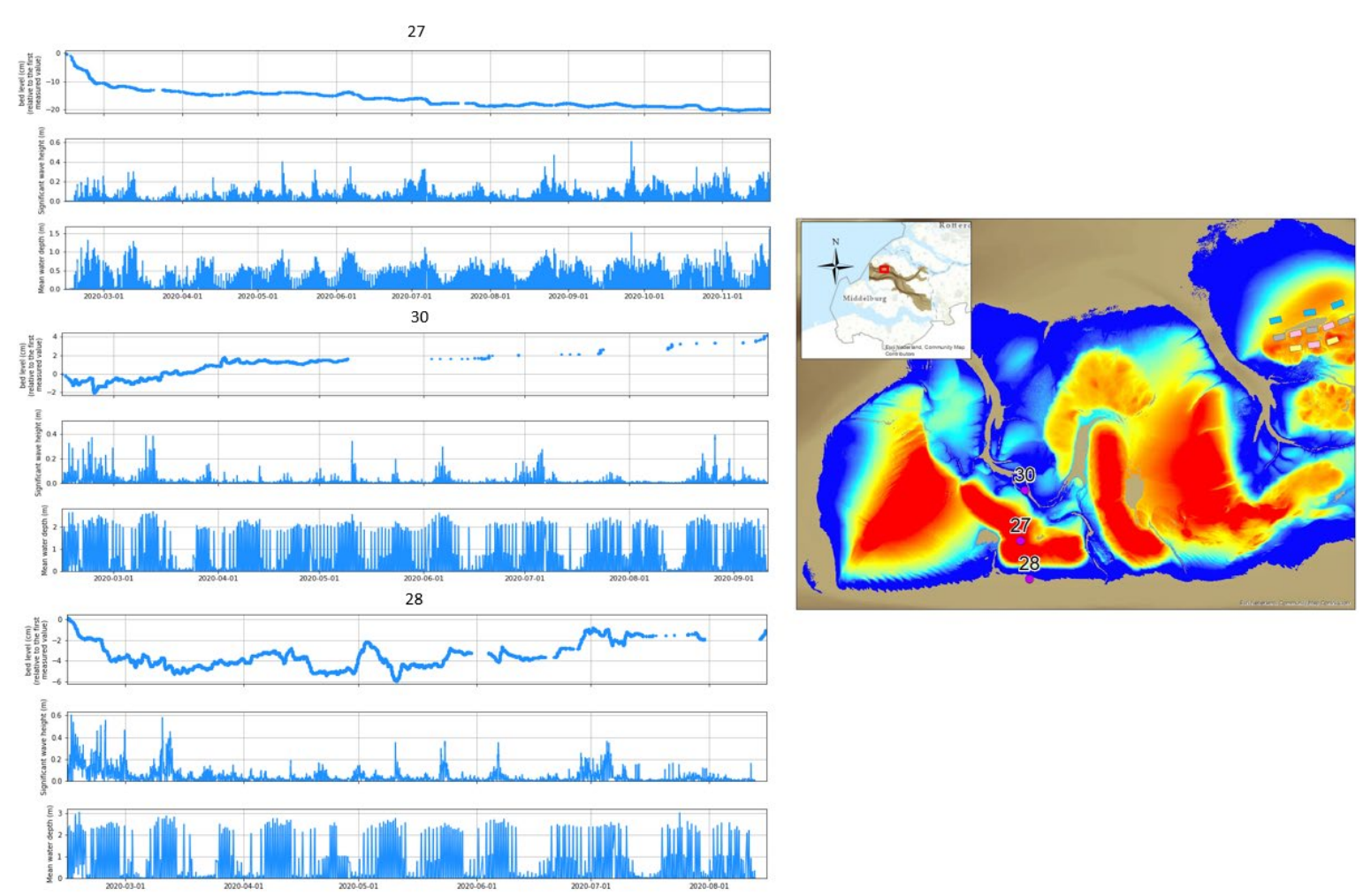

Figuur 6-13 Akoestische SED punt 27, 28 en 30 met bodemhoogte, significante golfhoogte en gemiddelde waterdiepte.

\subsubsection{Ontwikkeling afwateringsgeulen}

\subsubsection{Methode}

In de Roggenplaat zijn twee grote afwateringsgeulen aanwezig (Middengeultje en Westgeultje). Deze geulen vormen een belangrijk onderdeel van de morfologie van de Roggenplaat en beïnvloeden de stroming op de plaat. Beide geulen zijn voor dit project met Multibeam ingemeten in mei 2015. Voor het Middengeultje is de meting in april 2019, december 2019, juni 2020 en november 2020 herhaald. De metingen zijn beschikbaar op een $1 \mathrm{~m}$ bij $1 \mathrm{~m}$ rooster, hebben een verticale nauwkeurigheid van ongeveer $10 \mathrm{~cm}$ en zijn daarmee geschikt om te bepalen of het Middengeultje migreert en/of in omvang verandert. Voor het Westgeultje is één meting beschikbaar waardoor morfologische ontwikkelingen in de tijd niet gevolgd kunnen worden. De resultaten hiervan zijn de vinden in Walles et al. (2021).

\subsubsection{Resultaten}

De metingen in 2020 duiden vooralsnog geen zichtbare veranderingen in de ontwikkeling van het Middengeultje (Figuur 6-14, Figuur 6-15). De noordoostelijke migratie van de zuidwestelijke geulwand die in de eerdere rapportage al zichtbaar was (Walles et al. 2021) zet door. De aanvullende Multibeam metingen in de komende jaren zijn noodzakelijk om robuust vast te stellen of de ontwikkeling van het Middengeultje inderdaad niet beïnvloed wordt door de aanwezigheid van de suppletie-elementen. Deze analyse zal in een latere fase van het project plaatsvinden, zodra aanvullende Multibeam metingen (2021-2024) beschikbaar zijn. 

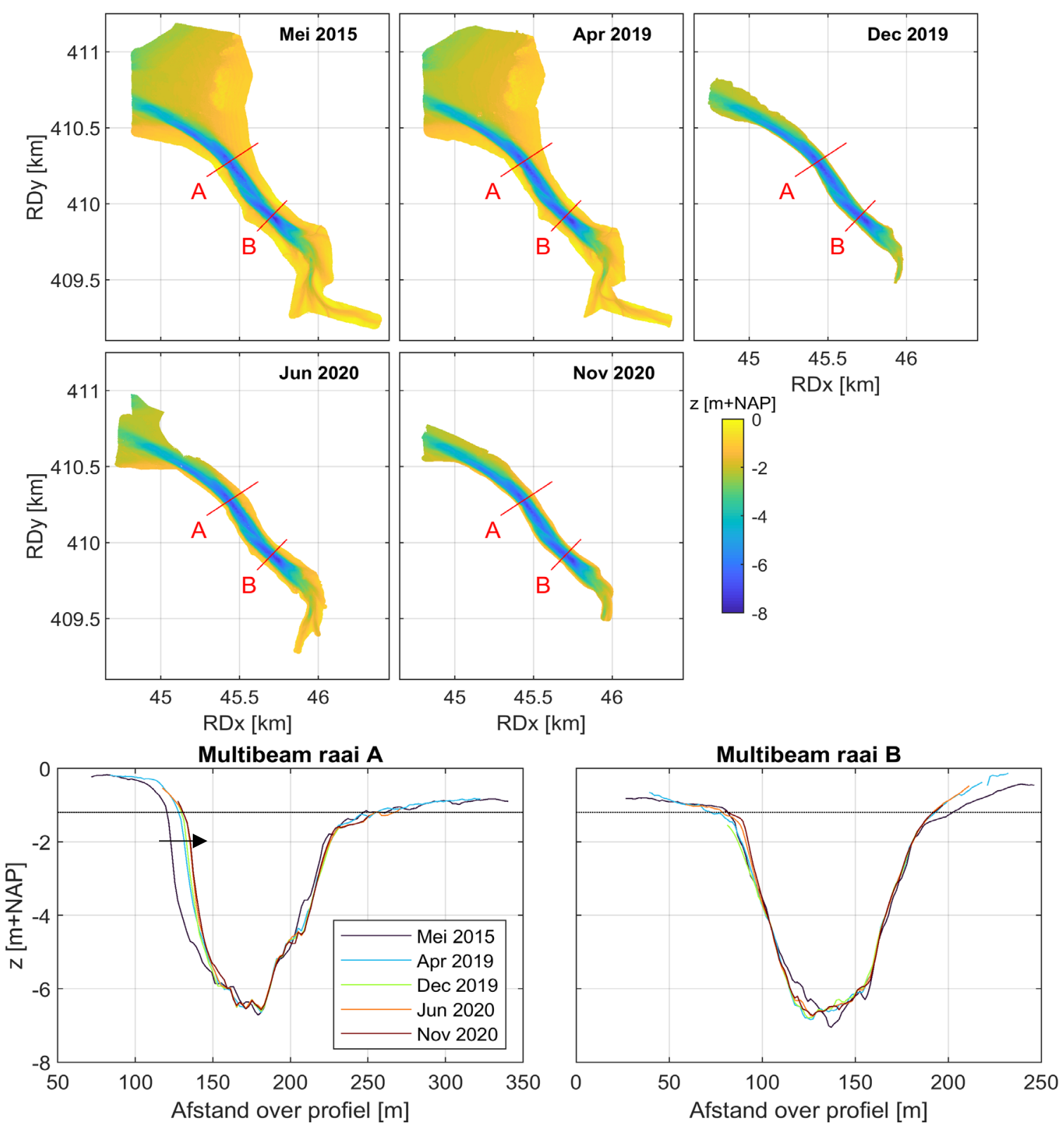

Figuur 6-14. Multibeam opnamen Middengeultje Roggenplaat van 2015 tot en met 2020 (boven) en profielen geïnterpoleerd langs raai A en raai B (onder). De afstand langs de profielen is positief in noordoostelijke richting. De gemiddeld laagwater lijn is met de zwarte stippellijn weergeven. In de profielen is de noordoostelijke migratie van de zuidwestelijke geulwand zichtbaar, met name ter hoogte van raai A (zwarte pijl). 


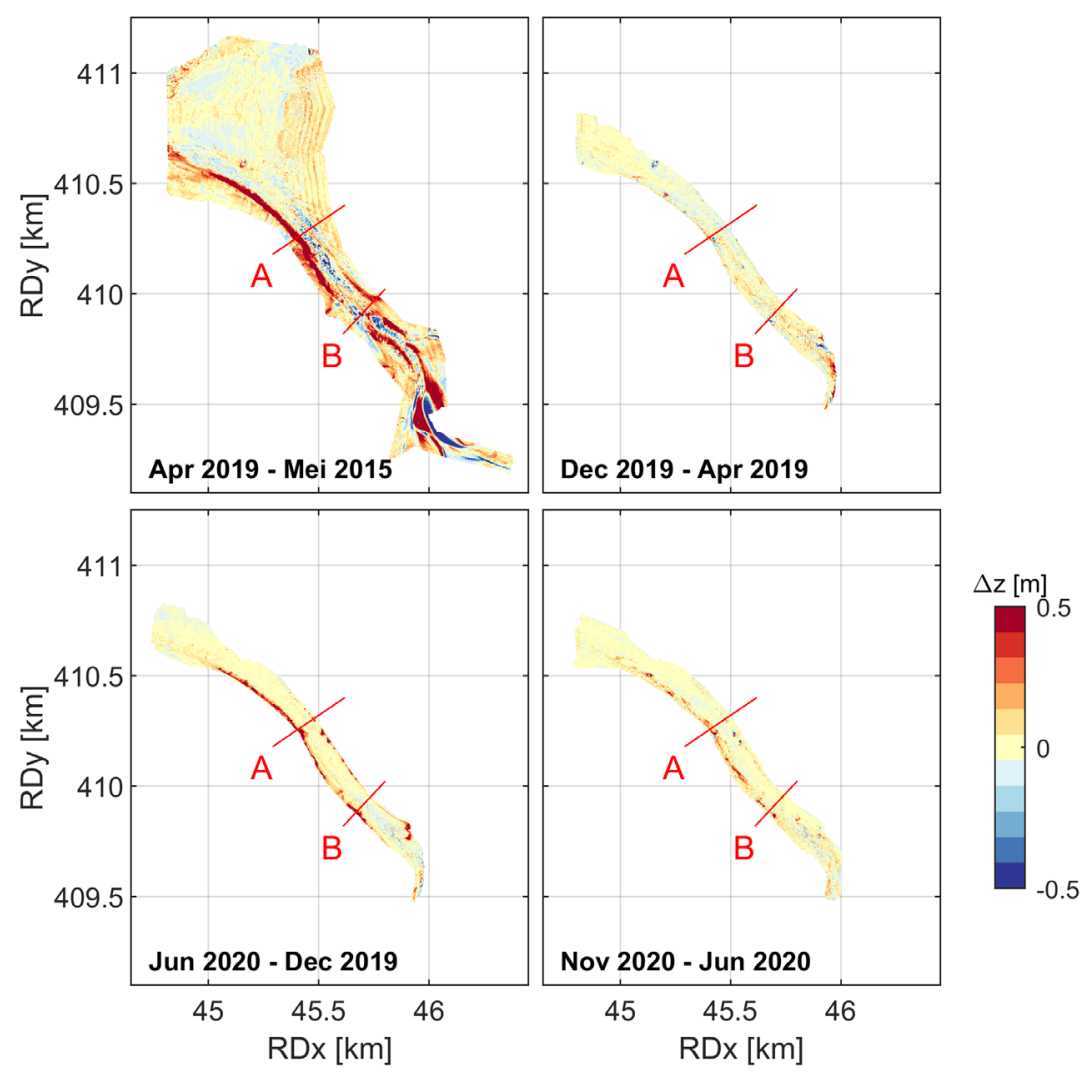

Figuur 6-15. Verschilkaarten van de Multibeam opnamen van 2015 tot en met 2020 van het Middengeultje. De profielen langs de rode lijnen zijn weergeven in Figuur 6-14.

Een vergelijking tussen de Multibeam data van mei 2015 en april 2019 - de jaren met de grootste ruimtelijke dekking van deze data - toont dat de oorsprong van het Middengeultje (het zuidoosten van het Middengeultje) een morfologisch dynamisch gebied is (Figuur 6-16). Dit is ook zichtbaar in de LiDAR data (omcirkeld in Figuur 6-2). Twee aftakkingen van het Middengeultje zijn lokaal meer dan een halve meter aangezand en de grootste lokale aftakking lag in 2019 ongeveer 50 m naar het oosten ten opzichte van 2015 (gemarkeerd in Figuur 6-16). Het is nog onduidelijk of de geul aan een cyclische ontwikkeling onderhevig is of dat dit een blijvende verandering in de lokale morfologie van het Middengeultje is.
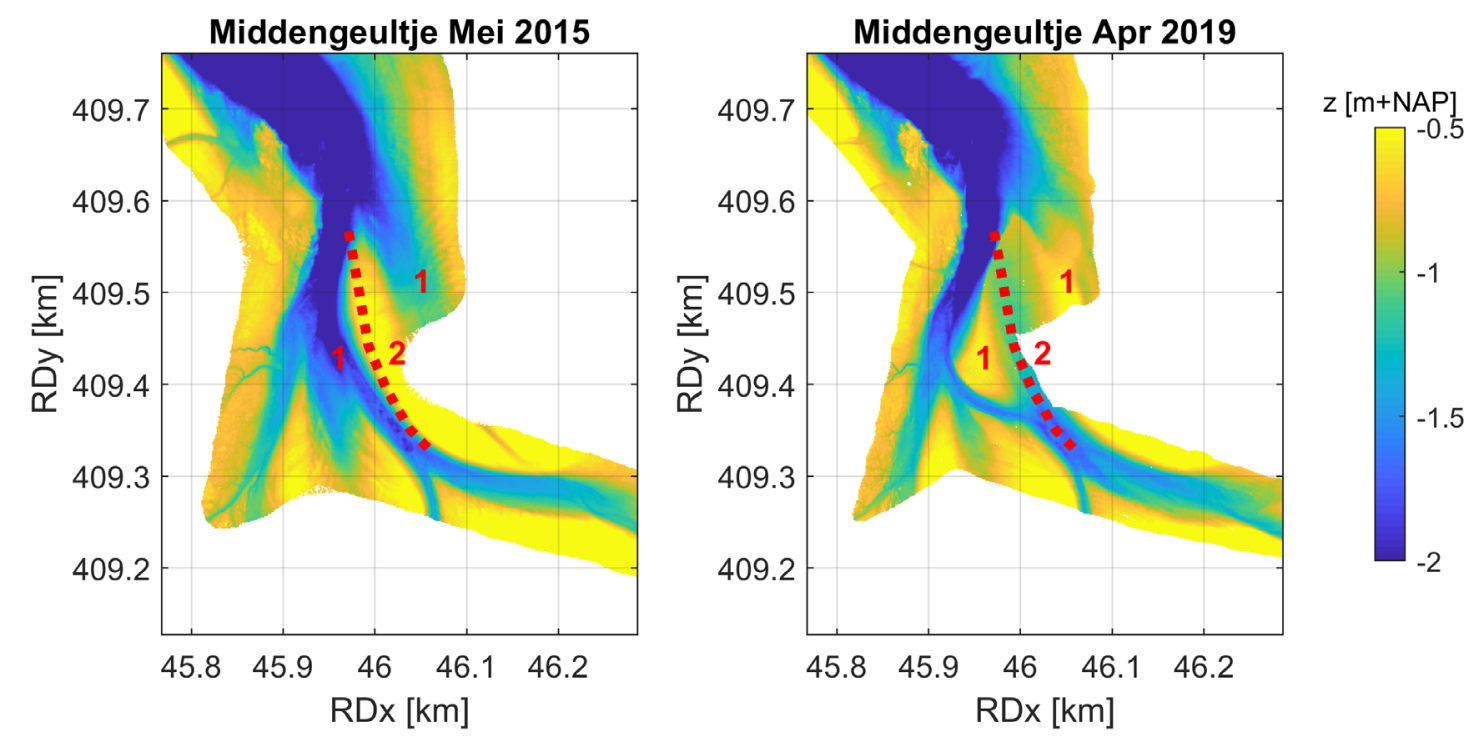

Figuur 6-16. Detailopname van de Multibeam data, gefocust op de morfologische patronen in het zuidoosten van het Middengeultje in mei 2015 (links) en april 2019 (rechts). Aangezande geultjes zijn met 1 gemarkeerd, de nieuwe locatie van het geultje is met de stippellijn en 2 gemarkeerd. 


\subsubsection{Droogvalduur}

\subsubsection{Methode}

Voor de foerageerfunctie voor vogels is droogvalduur een belangrijke parameter. De ontwikkeling van het areaal droogvalduur over de tijd is geëvalueerd met behulp van LiDAR hoogtekaarten, omgezet naar droogvalduur. Areaal droogvalduur is bepaald door de bodemligging te combineren met de cumulatieve verdeling van de waterstanden. Voor de omzetting naar droogvalduur (zie Bijlage 3 ) is gebruik gemaakt van de waterstanden gemeten bij 'Roompot binnen'. Vervolgens is per droogvalduurklasse het areaal per jaar berekend.

Opgemerkt wordt dat de bepalingen van de arealen in de droogvalduurklassen $0-10 \%$ en $10-20 \%$ (relatief) onnauwkeurig zijn omdat niet alle delen van de plaat met deze bodemhoogten in de LiDAR dataset zijn opgenomen. Toch heeft het gebruik van LiDAR data de voorkeur omdat niet voor elk jaar vaklodingen data beschikbaar zijn. In de LiDAR dataset ontbreken de delen van de plaat die onder water stonden tijdens de metingen zoals ook al opgemerkt in paragraaf 6.2.1. Welke delen ontbreken varieert over de jaren. Kleine variaties in arealen in de hogere droogvalduurklassen kunnen te maken hebben met kleine gaten in de LiDAR dataset als gevolg van lokale metingen die niet voldoen aan de kwaliteitseisen (bijvoorbeeld het gevolg van poeltjes). Ondanks deze beperkingen is de LiDAR dataset nuttig voor het volgen van de ontwikkeling van de droogvalduurklassen.

\subsubsection{Resultaten}

Veranderingen in het areaal droogvalduur over de tijd, op de gehele Roggenplaat, zijn in Figuur 6-17 weergegeven basis van data verkregen uit laseraltimetrie ingewonnen tussen 2001 en februari 2020. Het areaal met 80-100\% droogvalduur toont een duidelijke afname over de tijd. Arealen van de overige droogvalduurklassen laten afwisselend een periode van toename en afname zien.

Door aanleg van de suppleties is het areaal in de droogvalduurklassen $40-50 \%$ sterk afgenomen en is daarvoor in de plaats een sterke toename te zien van het areaal met een droogvalduurklassen van $50-80 \%$ als gevolg van het aangebrachte sediment (weer ruim terug op het niveau van rond 2001). Tot slot is de hoogste droogvalduurklassen van $90-100 \%$ afgenomen na aanleg van de suppleties. Binnen deze $90-100 \%$ droogvalduurklassen valt de schelpenbult aan de oostrand van de Roggenplaat. Deze schelpenbult lijkt sinds de aanleg van de suppleties in hoogte af te nemen, een trend die reeds gaande was.

$\mathrm{Na}$ aanleg is het areaal van de droogvalduurklassen $70-90 \%$ afgenomen. RTK raaien lieten eerder al zien dat de hoogste suppleties (element 4) in de orde van $10 \mathrm{~cm}$ zijn gedaald, wat mogelijks deze afname kan verklaren. Echter heeft de afname niet geleid tot een toename in de lagere droogvalduurklassen. Dit zou mogelijks het gevolg kunnen zijn van gaten in de LiDAR opname van oktober 2020. 


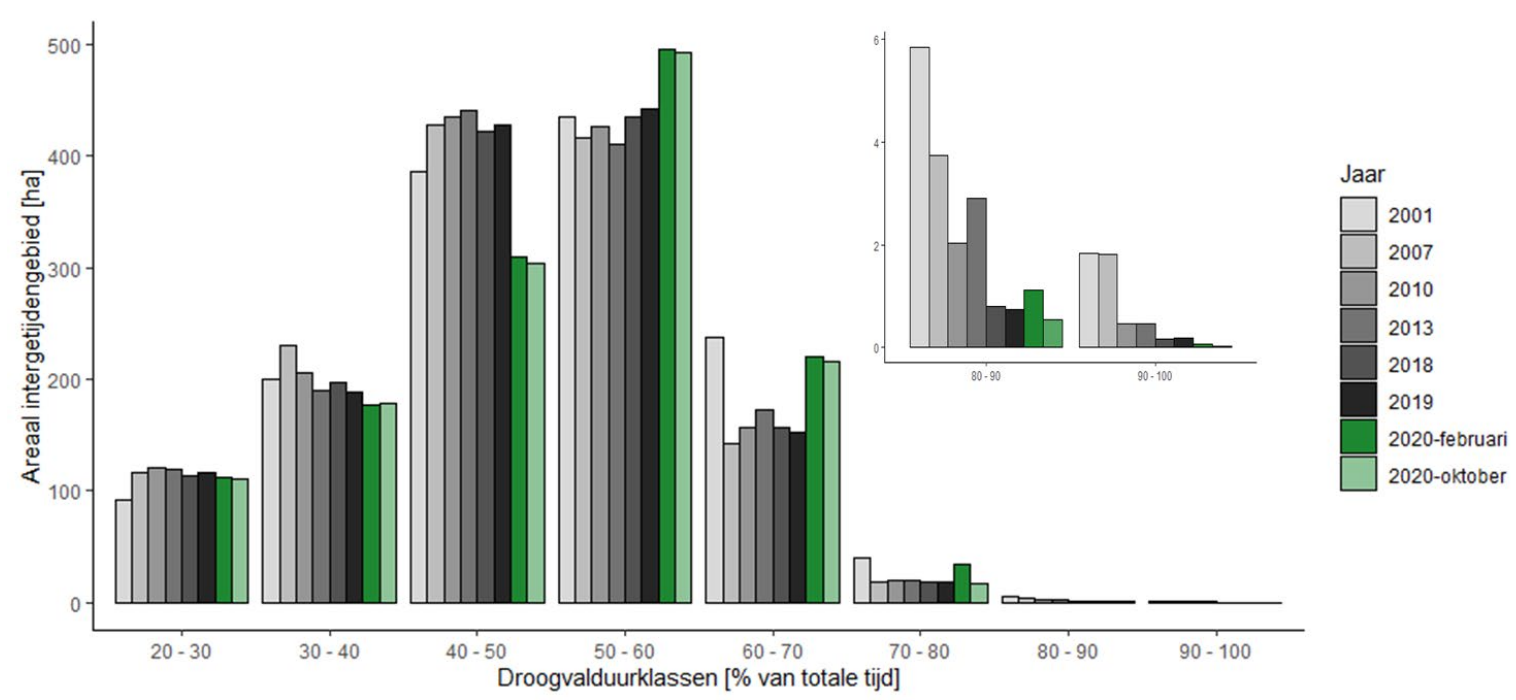

Figuur 6-17. Verandering in hectare areaal per droogvalduurklasse tussen 2001 en 2020. Groene balkjes geven de droogvalduur na aanleg van de suppletie weer, gemeten in februari en oktober 2020. De 0-20 DVD wordt buiten beschouwing gelaten.

\subsubsection{Sedimentsamenstelling}

\subsubsection{Methode}

Sedimentsamenstelling is een van de bepalende factoren voor bodemfauna en dus ook voor de foerageerfunctie voor wadvogels. Sedimentsamenstelling en het slibgehalte is bemonsterd op 113 locaties in het najaar van 2015 en 2019 (voor aanleg, zie Walles et al. 2021) en in het najaar van 2020 (na aanleg).

De 113 bemonsterde locaties dekken de suppletie onvoldoende. Om inzicht te krijgen in de sedimentsamenstelling op de suppletie zijn additioneel sedimentmonsters genomen in november 2020.

\subsubsection{Resultaten}

Het sediment op de Roggenplaat kan gemiddeld geclassificeerd worden als fijn zand (Tabel 5). De korrelgrootte verdeling is vergelijkbaar over de jaren, echter is de spreiding iets toegenomen na aanleg van de suppletie. Fijn zand vormt, zowel voor als na de aanleg, de grootste fractie. Na aanleg, is het aantal locaties met een zeer laag percentage aan slib, zeer fijn en fijn zand toegenomen. Ook zien we een toename in het aantal locaties met middel fijn en grof zand. Opvallend zijn de hogere slibpercentages na aanleg van de suppletie en een toename van het maximale slibpercentage met $\sim 10 \%$, echter gaat het hier om enkele locaties.

De ruimtelijke verdeling van het sediment toont vooral in het westelijke deel van de Roggenplaat een hogere mediane korrelgrootte. Op deze locaties is vaak geen slib geobserveerd en is de fractie aan zeer fijn en fijn zand laag (Figuur 6-18). In de lager gelegen delen van de Roggenplaat is het sediment vaak fijner en het slibgehalte hoger. 
Tabel 5. Sedimentsamenstelling op de Roggenplaat. Grof zand = fractie tussen $0.5-1.0 \mathrm{~mm}$, Middel fijn zand $=0.25-0.5 \mathrm{~mm}$, Fijn zand $=0.125-0.25 \mathrm{~mm}$, Zeer fijn zand $=$ $0.063-0.125 \mathrm{~mm}$, Slib $=<0.063 \mathrm{~mm} ; \mathrm{D} 50=$ mediane korrelgrootte van de totale sedimentfractie.

\begin{tabular}{|c|c|c|c|c|c|c|c|c|c|}
\hline & \multicolumn{3}{|c|}{$\begin{array}{c}2015 \\
n=113\end{array}$} & \multicolumn{3}{|c|}{$\begin{array}{c}2019 \\
n=112\end{array}$} & \multicolumn{3}{|c|}{$\begin{array}{c}2020 \\
n=113\end{array}$} \\
\hline & $\mu \pm s d$ & Min & $\operatorname{Max}$ & $\mu \pm s d$ & Min & Max & $\mu \pm s d$ & Min & Max \\
\hline Grof zand (\%) & $0,4 \pm 0,7$ & 0 & 3,5 & $0,5 \pm 0,8$ & 0 & 3,7 & $0,9 \pm 1,4$ & 0 & 7,0 \\
\hline Middel fijn zand (\%) & $31,4 \pm 12$ & 3,4 & 60,9 & $32,3 \pm 22$ & 4,4 & 59,9 & $35,4 \pm 16$ & 4,7 & 70,0 \\
\hline Fijn zand (\%) & $57,4 \pm 9,0$ & 33,0 & 74,0 & $56,8 \pm 9,3$ & 36,5 & 73,3 & $53,8 \pm 12$ & 23,2 & 73,7 \\
\hline Zeer fijn zand (\%) & $6,6 \pm 5,6$ & 0,1 & 31,2 & $6,1 \pm 5,6$ & 0,1 & 36,1 & $5,9 \pm 6,5$ & 0 & 29,0 \\
\hline Slib (\%) & $4,1 \pm 5,8$ & 0 & 32,6 & $4,2 \pm 5,5$ & 0 & 31,7 & $4,0 \pm 7,3$ & 0 & 45,7 \\
\hline D50 $(\mu \mathrm{m})$ & $210 \pm 31$ & 99,4 & 282 & $212 \pm 32$ & 119 & 281 & $218 \pm 43$ & 92,8 & 316 \\
\hline
\end{tabular}



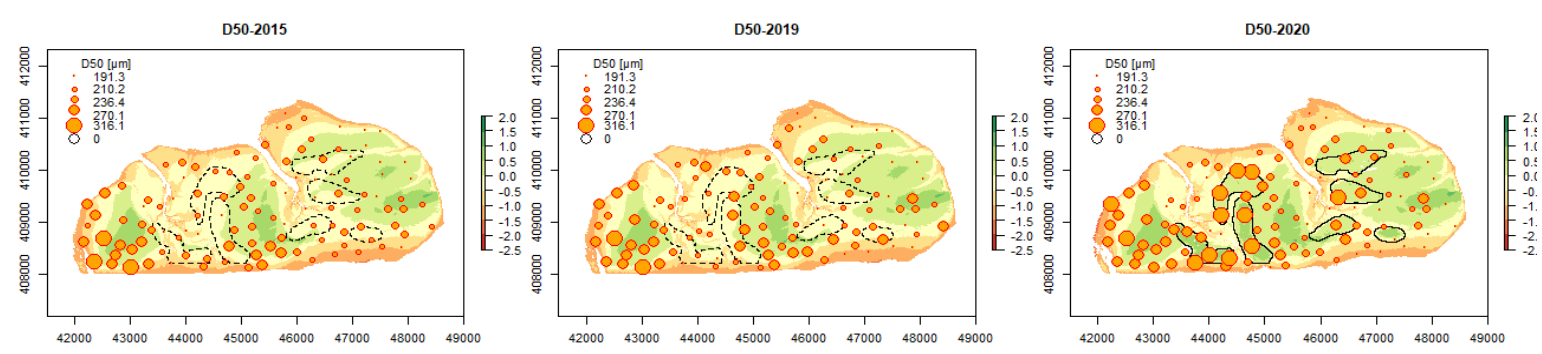

silt-2015

silt-2019
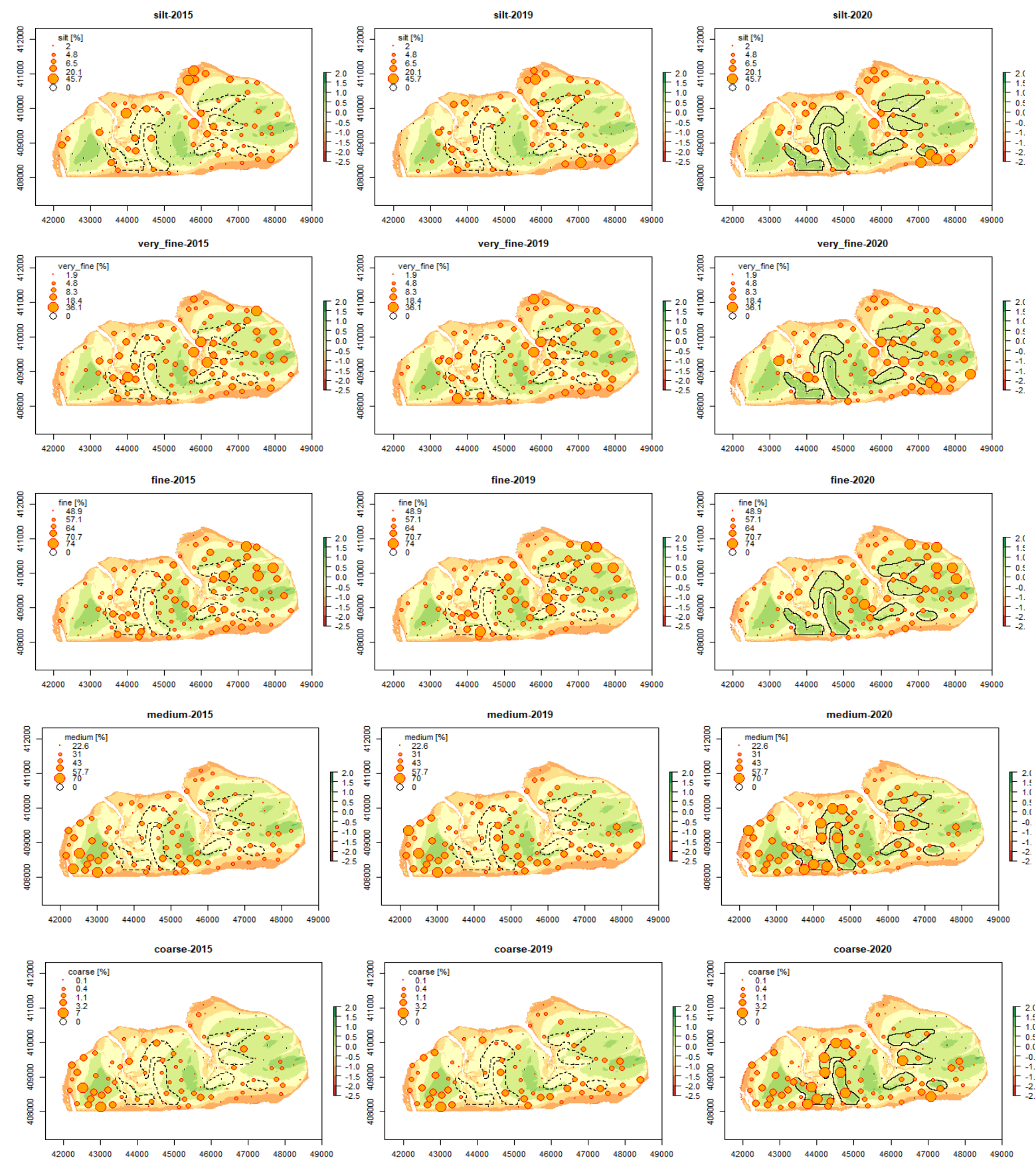

Figuur 6-18. Ruimtelijke verdeling van de mediane korrelgrootte (D50), slib percentage en grof, middel, fijn en zeer fijn zand percentages voor 2015, 2019 en 2020. De grootte van de bolletjes corresponderen met de $25^{\text {ste }}, 50^{\text {ste }}, 75^{\text {ste }}$ en $95^{\text {ste }}$ percentielen van de desbetreffende variabele. De achtergrondkaart is de hoogtekaart van 2019 (voor 2015 en 2019) en van 2020 (voor 2020), verkregen uit laseraltimetrie. De contouren van de suppletie-elementen (zwarte lijn) zijn weergegeven in 2020. Ter oriëntatie zijn de contouren van de suppletie-elementen (stippellijn) ook in de kaarten van 2015 en 2019 toegevoegd. 
De suppletie-elementen bestaan voornamelijk uit middel fijn en grof zand (Figuur 6-19) en wijken hiermee af van het gemiddelde sediment op de Roggenplaat (Figuur 6-20). Suppletie 5 heeft de hoogste mediane korrelgroottes en gemiddeld het hoogste percentage aan grof zand $(5.8 \pm 2.6 \%)$. Op suppletie-element $1,4,5$ en 7 is geen zeer fijn zand en slib gemeten. Suppletie-elementen 2, 3 en 6 hebben een klein percentage aan zeer fijn zand en slib. Deze suppleties bestaan uit een minder dikke laag gesuppleerd sediment. Het niet gesuppleerde gebied laat zowel in sedimentsamenstelling geen opvallende veranderingen zien tussen voor en na aanleg.
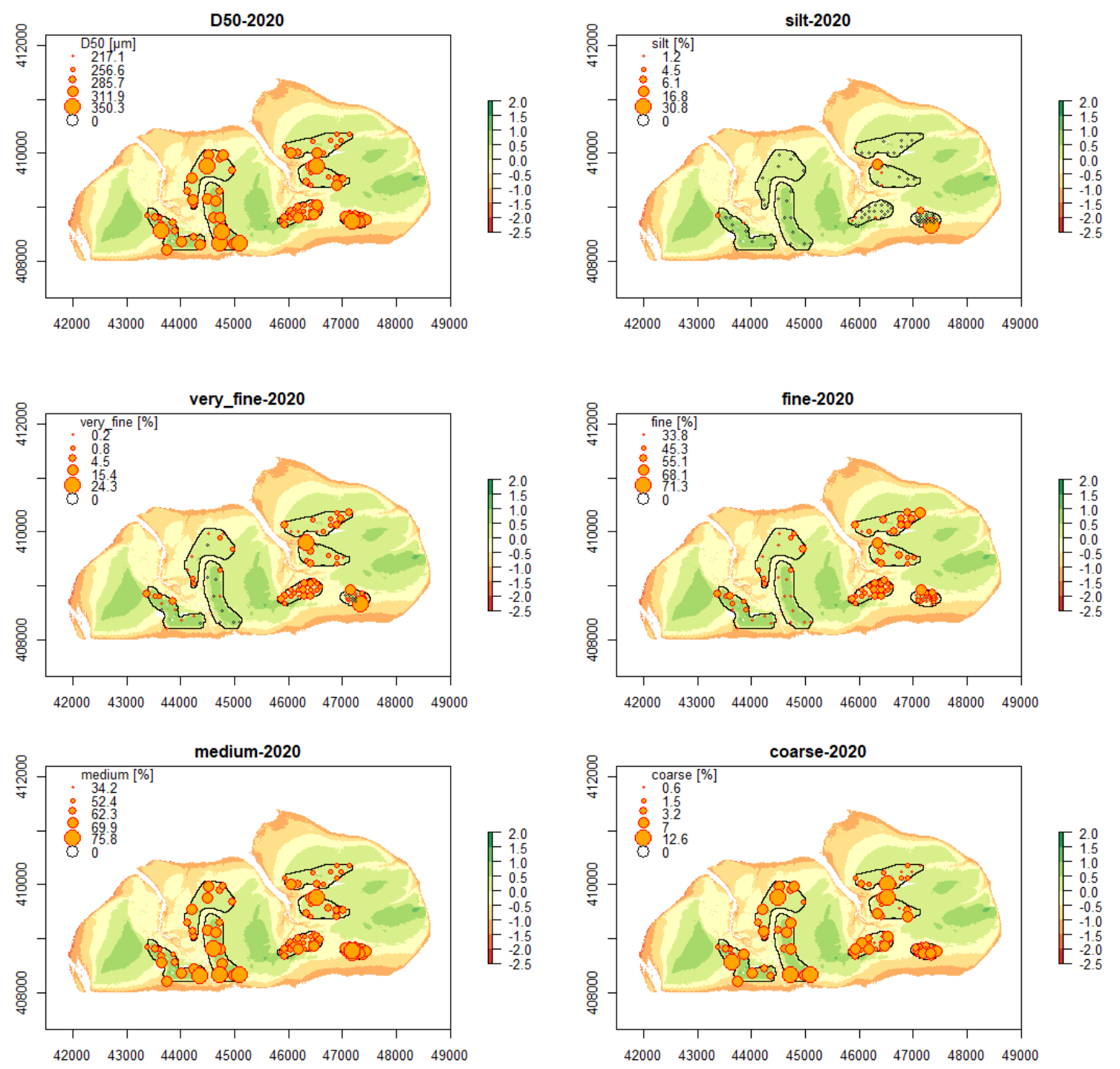

Figuur 6-19 Ruimtelijke verdeling van de mediane korrelgrootte (D50), slib percentage en grof, middel, fijn en zeer fijn zand percentages gemeten in november 2020 op de suppleties. De grootte van de bolletjes corresponderen met de $25^{\text {ste }}, 50^{\text {ste }}, 75^{\text {ste }}$ en $95^{\text {ste }}$ percentielen van de desbetreffende variabele. De achtergrondkaart is de hoogte kaart van 2020 verkregen uit laseraltimetrie. De contouren van de suppletie-elementen (zwarte lijn) zijn weergegeven. 

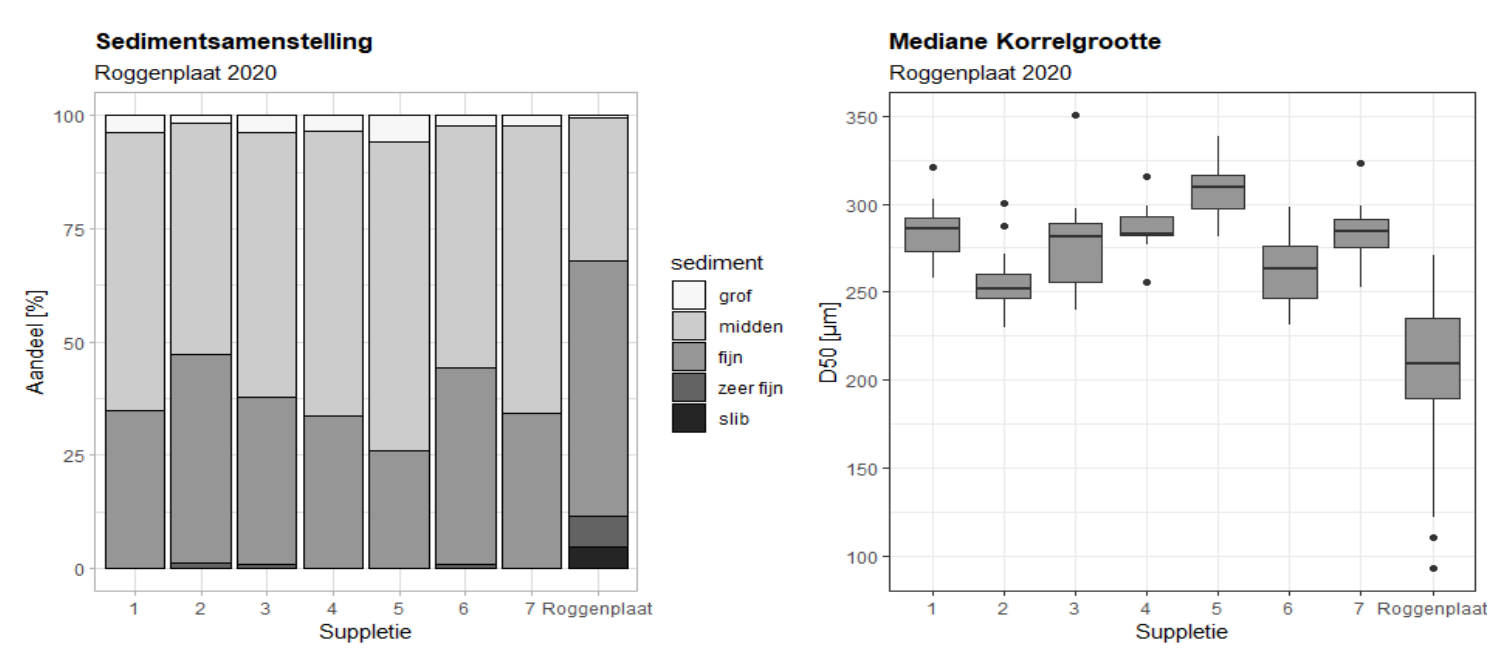

Figuur 6-20 Sedimentsamenstelling (gebaseerd op gemiddelden) (links) en mediane korrelgrootte (rechts) per suppletie-element en voor de ongesuppleerde delen van de Roggenplaat.

\subsubsection{Stroom- en golfmetingen}

\subsubsection{Methode}

Op 16 meetpunten verspreid over de Roggenplaat zijn stroom- en golfmetingen uitgevoerd tussen 24 februari en 25 maart 2015 (T0 metingen). De T1 metingen staan ingepland tussen 16 maart en 13 april 2021 (Figuur 6-21). De aanvullende stroommetingen in het Middengeultje zijn uitgevoerd tussen 13 januari en 23 februari 2021 (Figuur 6-21). De T0 metingen van de stroming in het Middengeultje zal integraal worden geanalyseerd met de T1 metingen in dit geultje, in een volgende rapportage. Deze metingen zullen inzicht verschaffen op hoe de suppletie-elementen de stroming in het Middengeultje beïnvloeden. Ook zullen deze metingen gebruikt gaan worden om het Delft3D model nader te valideren.

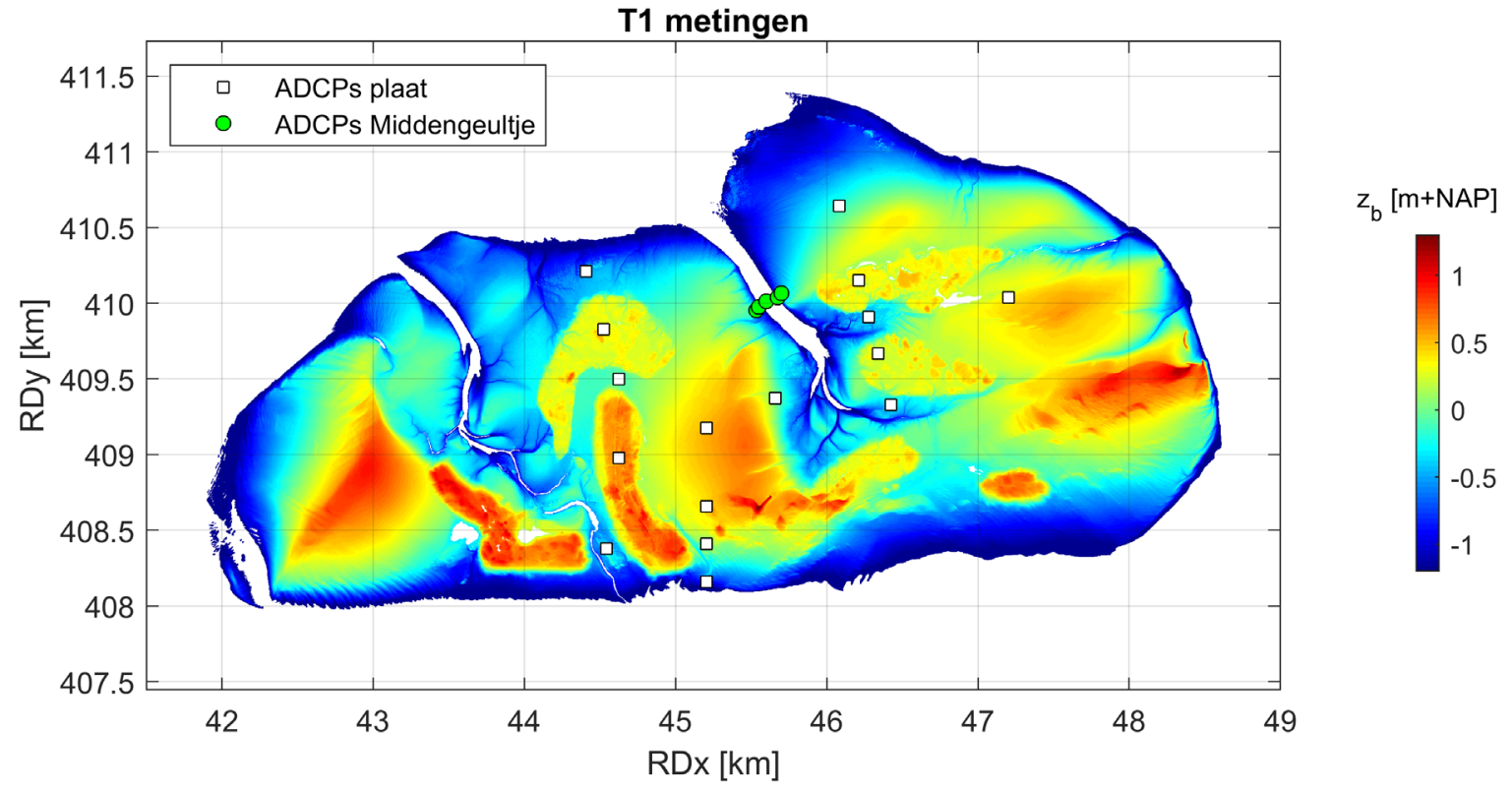

Figuur 6-21 Locatie van de ADCPs op de plaat en in het Middengeultje in 2021. 


\subsection{Ecologische ontwikkelingen}

Het uiteindelijke doel van de Roggenplaat suppletie is het in standhouden van voldoende foerageergebied voor steltlopers waarvoor de Oosterschelde van internationaal belang is. De draagkracht van een getijdenplaat voor steltlopers wordt primair bepaald door het voedselaanbod. De hoeveelheid geschikt voedsel dat aanwezig is, maar ook de bereikbaarheid, conditie en de afmetingen (bv schelpgroottes) van dat voedsel bepalen welke soorten en in welke dichtheden deze soorten kunnen voorkomen. Voor steltlopers zijn bodemdieren het belangrijkste voedsel. Bodemdieren stellen vaak specifieke eisen aan hun omgeving. Droogvalduur, dynamiek en sedimentsamenstelling bepalen in belangrijke mate het voorkomen. De ecologische ontwikkeling is hierdoor direct gekoppeld aan de morfologische ontwikkeling van de Roggenplaat.

Voor het onderzoeken van de ecologische ontwikkeling van de Roggenplaat zijn verschillende metingen uitgevoerd. Middels deze metingen wordt onderzocht: de ruimtelijke verspreiding van het bodemdierleven op de Roggenplaat; de ontwikkeling van het bodemdierleven op de suppletie; de ontwikkeling in laagwaterverspreiding van de steltlopers voor en na aanleg van de suppletie. Tevens komen de lange-termijn ontwikkeling van kokkels en oesterbanken aan bod. De plaat heeft ook een belangrijke functie als liggebied voor gewone zeehonden. Daarom rapporteren we ook de trends in de zeehondenaantallen.

In de eerstvolgende paragraaf wordt de analyse van het bodemdierleven van de gehele Roggenplaat in de T0 en T1 situatie gepresenteerd; de bodemdierontwikkeling per suppletie-element; en de ontwikkeling van het bodemdierleven binnen de priming. Tevens komen de lange-termijn ontwikkelingen van kokkels en oesterbanken aan bod. Vervolgens presenteren we de ontwikkeling in laagwaterverspreiding van de steltlopers voor en na aanleg van de suppletie en de ontwikkeling van de zeehondenaantallen.

\subsubsection{Benthische macrofauna}

\subsubsection{Methode}

Om inzicht te krijgen in de (ruimtelijke) verspreiding van het macrozoöbenthos zijn twee bemonsteringen uitgevoerd op de Roggenplaat: kwantitatief en via een snelle veldscreening (kwalitatief). De kwantitatieve benthosbemonstering levert informatie over de voedselbeschikbaarheid op een bepaalde locatie, inclusief de biomassa. Middels de veldscreening kan een hogere ruimtelijke dekking verkregen worden, echter is de beperking van deze methode dat vooral gescoord wordt op aanwezigheid van een soort (en voor twee soorten, wadpier en kokkel, een indicatie van de aantallen), en er geen informatie beschikbaar is over aantallen of biomassa's. Tevens is het aantal soorten dat in het veld gemakkelijk en snel kan worden herkend beperkt.

$\mathrm{Na}$ aanleg van de suppletie is in totaal op 113 locaties, verspreid over de Roggenplaat, een kwantitatieve bemonsterd uitgevoerd in september conform de methode beschreven in Walles et al. 2021. Het gaat hier om dezelfde locaties als bemonsterd in 2015 en 2019. Voor de bodemdierontwikkeling op de afzonderlijke suppletie-elementen is in November 2020 additioneel een kwantitatieve bemonstering uitgevoerd. Deze bemonstering is alleen uitgevoerd na aanleg van de suppletie en zal jaarlijks opgevolgd worden. De bemonstering is uitgevoerd volgens een stratified random design: 3 zones per suppletieelement (top van de suppletie, geëxponeerde zijde en luwe zijde) en 3 replica's per zone per suppletie (Figuur 6-22). Op suppletie-elementen 2 en 6 worden gedetailleerde fysische metingen uitgevoerd. Deze twee suppleties zijn om deze reden in meer detail, 
20 locaties per suppletie, bemonsterd. Ook suppletie-element 7 (compensatiemaatregel voor de vooroeverbestorting) is in meer detail bemonsterd (Figuur 6-23). In totaal zijn 96 locaties bemonsterd. Hiervan zijn 88 verwerkt ten tijde van deze rapportage. De acht nog te verwerken monsters, gelegen op suppletie-element 2 , vallen samen met referentielocaties van de priming bemonstering, zie paragraaf 6.3.3. Het uitzoekwerk van de priming heeft vertraging opgelopen. De totale biomassagetallen per locatie uit 2020 zijn nog niet beschikbaar ten tijde van het schrijven van deze rapportage. Om te onderzoeken of bodemdiergemeenschap verschillen tussen gesuppleerde en nietgesuppleerde gebieden en tussen suppletie-elementen zijn een multivariate analyses uitgevoerd. De multivariate analyses zijn uitgevoerd op basis van dichtheden per soort per monster. Onderlinge verschillen werden hierbij berekend door middel van de BrayCurtis coëfficent. In deze analyses zijn alleen de taxa (groep organismen die taxonomisch van andere groepen te onderscheiden eenheid vormt) meegenomen waarvan de dichtheid, bij minstens 3 monsters, meer dan $1 \%$ van de totale dichtheid in het betreffende monster uitmaakte. Tevens is de relatie met omgevingsfactoren onderzocht.

Op 328 locaties is na aanleg van de suppletie een veldscreening uitgevoerd. Aanvullend op de veldscreening in 2017 (zie Walles et al. 2021) is suppletie 7 bemonsterd.

\section{Suppletie Bemonster Locaties}

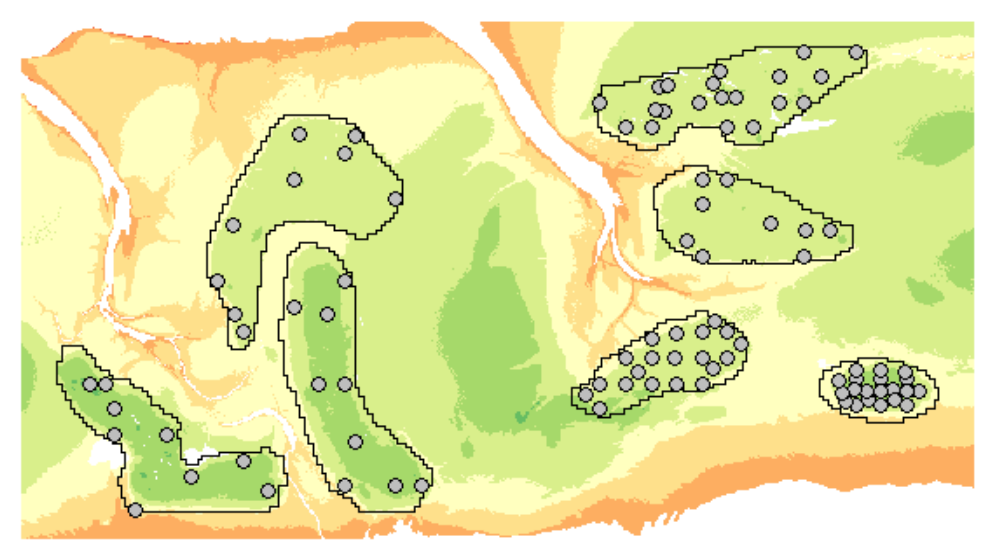

Figuur 6-22 Kwantitatieve benthosbemonstering van de suppletie-elementen volgens een stratified random design: 3 zones per suppletie-element (top van de suppletie, geëxponeerde zijde en luwe zijde) en 3 replica's per zone per suppletie-element. 


\section{Zones per suppletie}

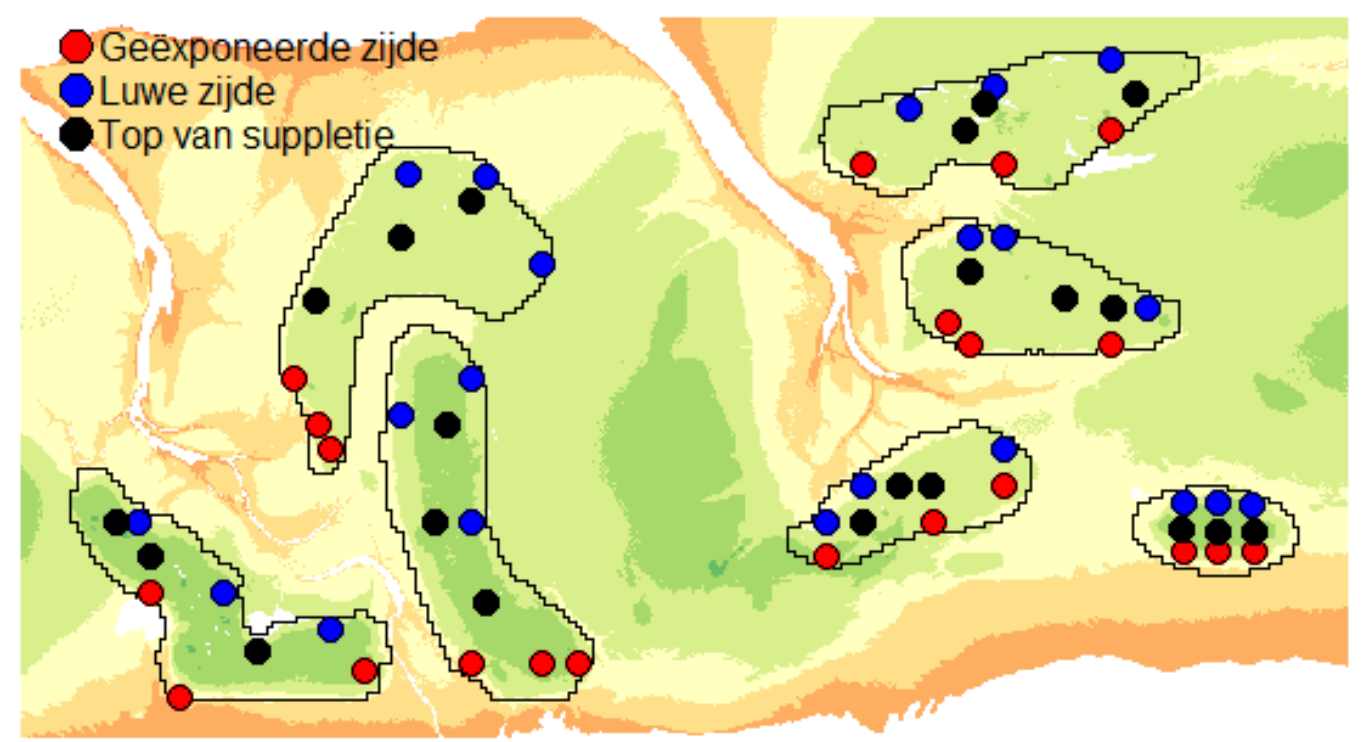

Figuur 6-23 Benthosbemonstering van de suppletie-elementen in november 2020 volgens een stratified random design: 3 zones per suppletie-element (top van de suppletie, geëxponeerde zijde en luwe zijde) en 3 replica's per zone per suppletie.

\subsubsection{Resultaten Roggenplaat}

Op alle locaties waar de kwantitatieve benthosbemonstering is uitgevoerd werden bodemdieren aangetroffen in het najaar 2020. In totaal zijn 76 verschillende taxa gevonden (Bijlage 4), gemiddeld 11 taxa per locatie. Net als voorgaande jaren is de meest voorkomende soort de wapenworm Scoloplos armiger, gevolgd door het bulldozerkreeftje Urothoe poseidonis. Laatste genoemde is wel afgenomen in dichtheid in 2020 ten opzicht van voorgaande jaren. Soortenrijkdom is in alle jaren laag in het laaggelegen deel aan de zuidkant van de Roggenplaat (Figuur 6-24). Locaties gelegen op de suppletie laten ook een lage soortenrijkdom zien. Totale dichtheden per locatie verschillen ruimtelijk op de Roggenplaat (Figuur 6-25), variërend tussen 42 en 53.900 individuen per $\mathrm{m}^{2}$ in 2015 (gem \pm sd: $5.108 \pm 6.543$ ), 127 en 19.225 individuen per $\mathrm{m}^{2}$ in 2019 (gem \pm sd: $4.116 \pm 3$ 459) en 42 en 41.465 individuen per $\mathrm{m}^{2}$ in 2020 (gem \pm sd: $3.727 \pm 5.211$ ). In laaggelegen delen, met name aan de zuidwestelijke kant van de Roggenplaat, zijn totale dichtheden in alle jaren relatief laag. Dit is na aanleg van de suppleties onveranderd. Dichtheden op de suppletie zijn duidelijk lager. Verderop gaan we verder in op de bodemdiergemeenschap op de suppletie. Het gebied ten westen van suppletie 4 toont lagere dichtheden dan voorheen. Dit zou jaar tot jaar variatie kunnen zijn gezien de variatie gemeten tijdens de TO in dit gebied. Tot slot laten gebieden rond en tussen de suppleties geen sterke toe- of afname zien.
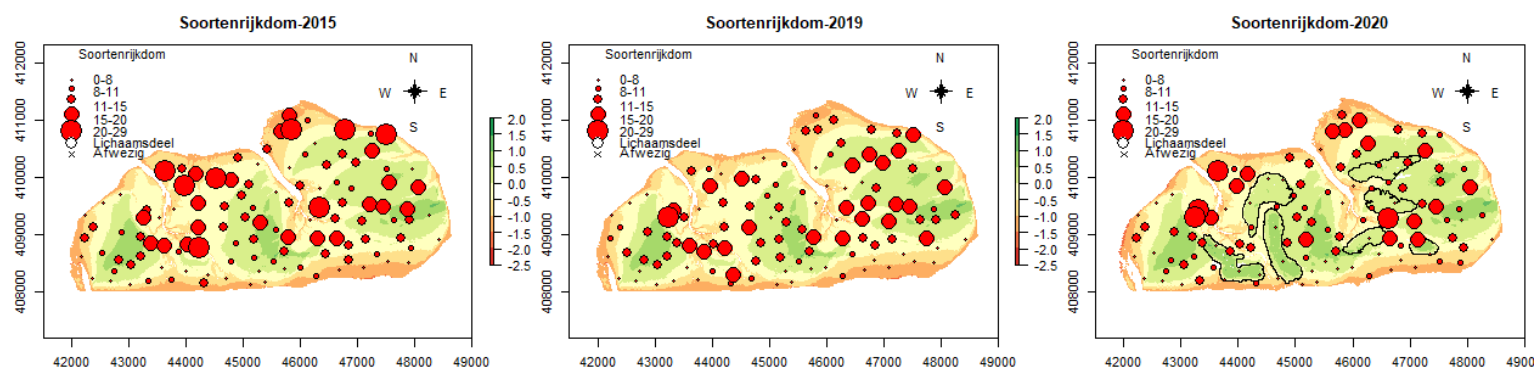

Figuur 6-24. Soortenrijkdom (aantal soorten) per bemonsteringslocatie. Achtergrondkaart: LiDAR RWS 2019. 

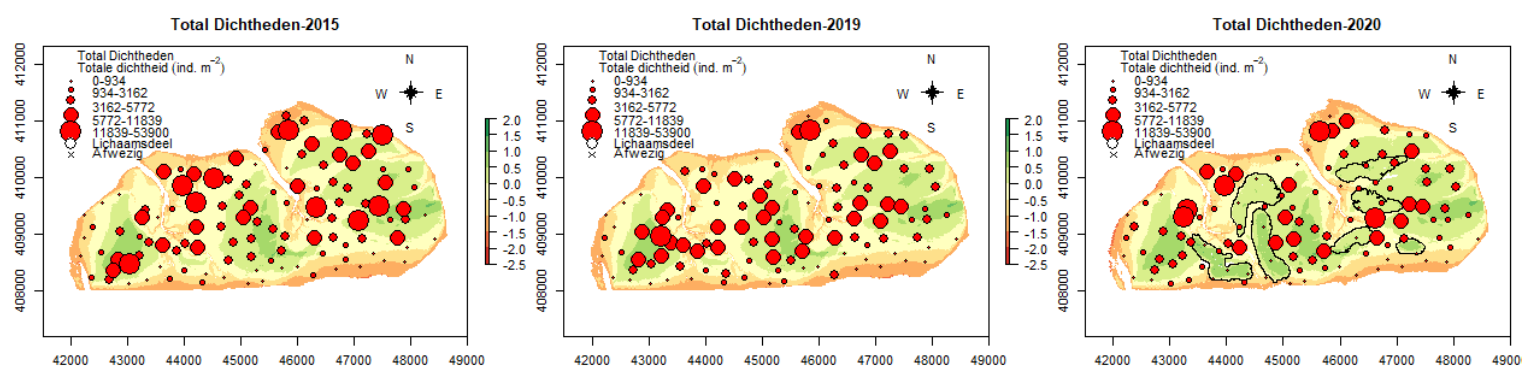

Figuur 6-25. Totale dichtheid (individuen $\mathrm{m}^{-2}$ ) per bemonsteringslocatie. De grootte van de bolletjes corresponderen met de $25^{\text {ste }}, 50^{\text {ste }}, 75^{\text {ste }}$ en $95^{\text {ste }}$ percentielen van de totale dichtheid. Achtergrondkaart: LiDAR RWS 2019.

In 2015 en 2019, vertegenwoordigde de borstelwormen Aphelochaeta spp., het bulldozerkreeftje Urothoe poseidonis, de wapenworm Scoloplos armiger en de ringwormen Oligochaeta de hoogste dichtheid op de Roggenplaat (Tabel 6, Figuur 6-26 en Figuur 6-27). In 2020 laat Aphelochaeta spp. een vergelijkbare gemiddelde dichtheid zien als in 2019, ruimtelijk wordt deze soort niet veel op suppleties waargenomen. De wapenworm, Scoloplos armiger komt in 2020 gemiddelde in lagere dichtheden voor. Opvallend is wel dat deze soort, in relatief hoge dichtheden, op de (oostelijke) suppleties voorkomt. Het bulldozerkreeftje (Urothoe poseidonis) lijkt de suppletie te mijden, echter wordt verderop duidelijk dat deze soort wel op de suppleties wordt waargenomen, maar wel in lagere dichtheden. De zandpijp, Pygiospio elegenas, is een opportunist die is toegenomen ten opzichte van 2015 en in hoge dichtheden voor komt op suppleties 1 en 4. Eerdere studies tonen aan dat hij verstoorde gebieden snel kan koloniseren (Desprez et al 1992, Kubbe en Powilleit, 1997). Borstelwormen, Capitellidae, is een opportunist die is toegenomen over de tijd en behoort tot een van de drie soorten die in hoogste dichtheid zijn aangetroffen; Het nonnetje, Limecola balthica is die fors in aantallen en voorkomen is afgenomen in 2020. Echter was er al een afname zichtbaar tussen 2015 en 2019. Het kniksprietkreeftje Bathyporeaia sarsi, welke een voorkeur heeft voor grof sediment, werd voor aanleg van de suppletie vooral in het westen van de plaat waargenomen, wordt nu ook op de suppletie aangetroffen.

Tabel 6. Frequentie van voorkomen (\% van de 113 locaties in 2015 , \% van de 112 locaties in 2019 en \% van de 113 locaties in 2020 waar een soort is aangetroffen) en dichtheden ( $\mu$ : aantal individuen per $\mathrm{m}^{2}$ ) per aangetroffen taxon op de Roggenplaat in 2015, 2019 en 2020. Taxa staan geordend naar frequentie van voorkomen in 2020.

\begin{tabular}{|c|c|c|c|c|c|c|c|c|c|c|c|c|}
\hline \multirow{2}{*}{ Taxa } & \multicolumn{4}{|c|}{2015} & \multicolumn{4}{|c|}{2019} & \multicolumn{4}{|c|}{2020} \\
\hline & $\%$ & $\boldsymbol{\mu}$ & \pm & sd & $\%$ & $\boldsymbol{\mu}$ & \pm & sd & $\%$ & $\boldsymbol{\mu}$ & \pm & sd \\
\hline Scoloplos armiger & 90 & 719 & \pm & 977 & 89 & 746 & \pm & 809 & 84 & 346 & \pm & 480 \\
\hline Urothoe poseidonis & 77 & 747 & \pm & 1046 & 77 & 872 & \pm & 1133 & 72 & 808 & \pm & 1199 \\
\hline Hediste diversicolor & 28 & 20 & \pm & 46 & 62 & 152 & \pm & 191 & 67 & 147 & \pm & 222 \\
\hline Pygospio elegans & 50 & 68 & \pm & 155 & 66 & 170 & \pm & 298 & 60 & 91 & \pm & 126 \\
\hline Arenicola marina & 52 & 47 & \pm & 92 & 61 & 48 & \pm & 59 & 52 & 35 & \pm & 44 \\
\hline Aphelochaeta spp. & 58 & 860 & \pm & 2205 & 53 & 574 & \pm & 1344 & 52 & 510 & \pm & 1212 \\
\hline Capitellidae & 49 & 293 & \pm & 1568 & 44 & 100 & \pm & 300 & 51 & 439 & \pm & 1763 \\
\hline Oligochaeta & 56 & 693 & \pm & 1718 & 55 & 347 & \pm & 885 & 44 & 399 & \pm & 1611 \\
\hline Limecola balthica & 71 & 165 & \pm & 365 & 61 & 107 & \pm & 227 & 42 & 40 & \pm & 62 \\
\hline Peringia ulvae & 33 & 136 & \pm & 459 & 16 & 88 & \pm & 462 & 33 & 153 & \pm & 348 \\
\hline Nephtys cirrosa & 13 & 8 & \pm & 22 & 6 & 3 & \pm & 12 & 32 & 26 & \pm & 52 \\
\hline
\end{tabular}




\begin{tabular}{|c|c|c|c|c|c|c|c|c|c|c|c|c|}
\hline $\begin{array}{l}\text { Heteromastus } \\
\text { filiformis }\end{array}$ & 19 & 21 & \pm & 64 & 38 & 66 & \pm & 225 & 31 & 48 & \pm & 200 \\
\hline Cerastoderma edule & 46 & 60 & \pm & 103 & 40 & 66 & \pm & 184 & 30 & 20 & \pm & 38 \\
\hline Corophium arenarium & 39 & 218 & \pm & 654 & 38 & 112 & \pm & 388 & 30 & 63 & \pm & 222 \\
\hline Lanice conchilega & 33 & 188 & \pm & 527 & 33 & 95 & \pm & 238 & 30 & 89 & \pm & 229 \\
\hline Polydora cornuta & 12 & 15 & \pm & 63 & 27 & 55 & \pm & 241 & 28 & 82 & \pm & 237 \\
\hline Malacoceros tetracerus & 15 & 18 & \pm & 67 & 25 & 219 & \pm & 1107 & 25 & 152 & \pm & 444 \\
\hline Streblospio benedicti & & & & & 25 & 27 & \pm & 76 & 25 & 44 & \pm & 165 \\
\hline Bathyporeia sarsi & 21 & 39 & \pm & 130 & 16 & 16 & \pm & 61 & 22 & 24 & \pm & 70 \\
\hline Phyllodoce mucosa & 32 & 69 & \pm & 267 & 20 & 16 & \pm & 43 & 19 & 24 & \pm & 93 \\
\hline Nereidinae & 27 & 25 & \pm & 65 & 50 & 51 & \pm & 79 & 16 & 25 & \pm & 87 \\
\hline Gammarus spp. & 27 & 88 & \pm & 342 & 8 & 16 & \pm & 73 & 7 & 18 & \pm & 131 \\
\hline $\begin{array}{l}\text { Austrominius } \\
\text { modestus }\end{array}$ & 1 & 49 & \pm & 519 & & & & & 3 & 4 & \pm & 31 \\
\hline Bathyporeia pilosa & 14 & 139 & \pm & 679 & & & & & 2 & 2 & \pm & 16 \\
\hline
\end{tabular}



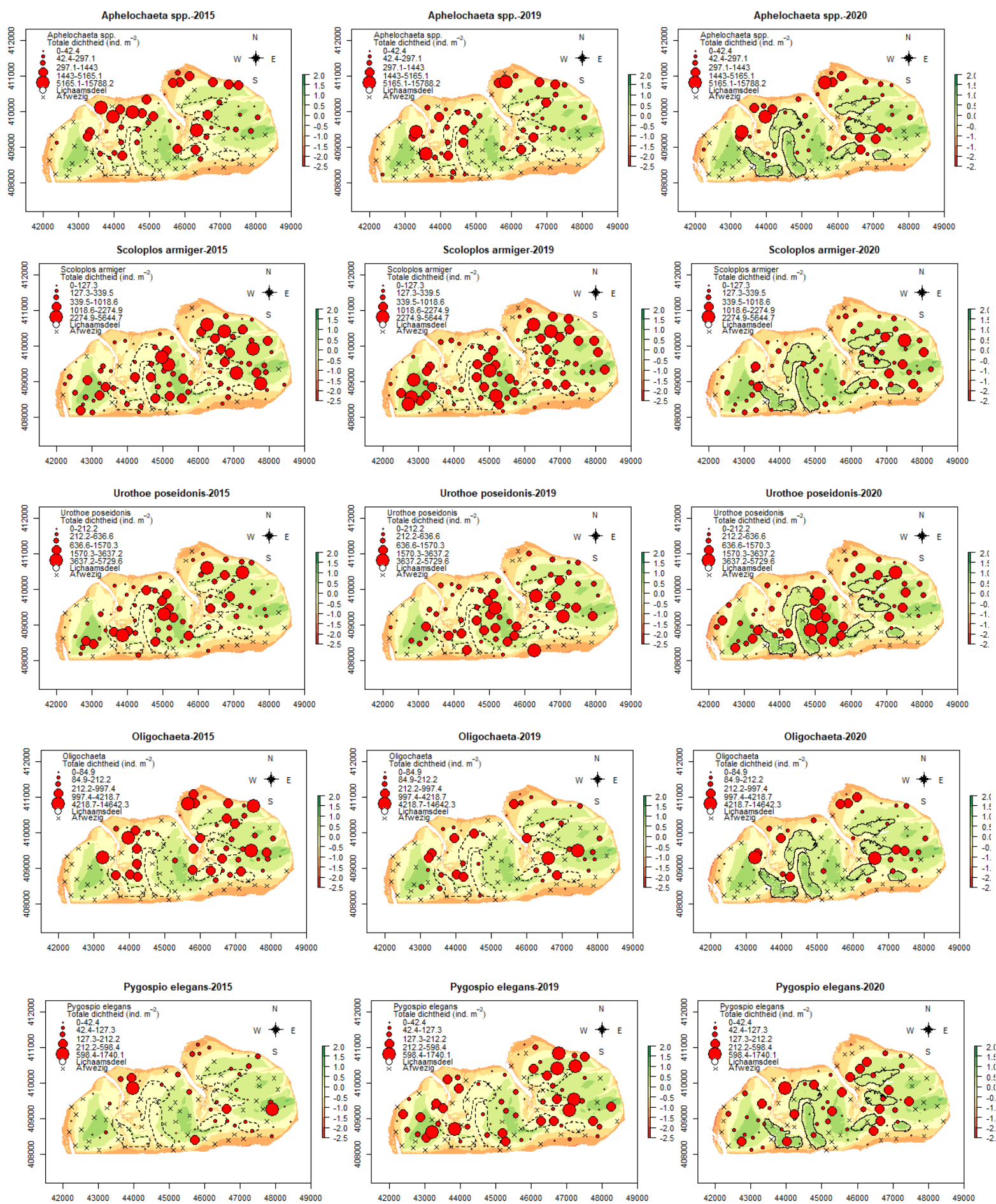

Figuur 6-26. Verspreidingskaart van Aphelochaeta spp., Scoloplos armiger, Urothoe poseidonis, Oligochaeta en Pygospio elegans op de Roggenplaat in 2015, 2019 en 2020. Achtergrondkaart: LiDAR 2019 en 2020. 

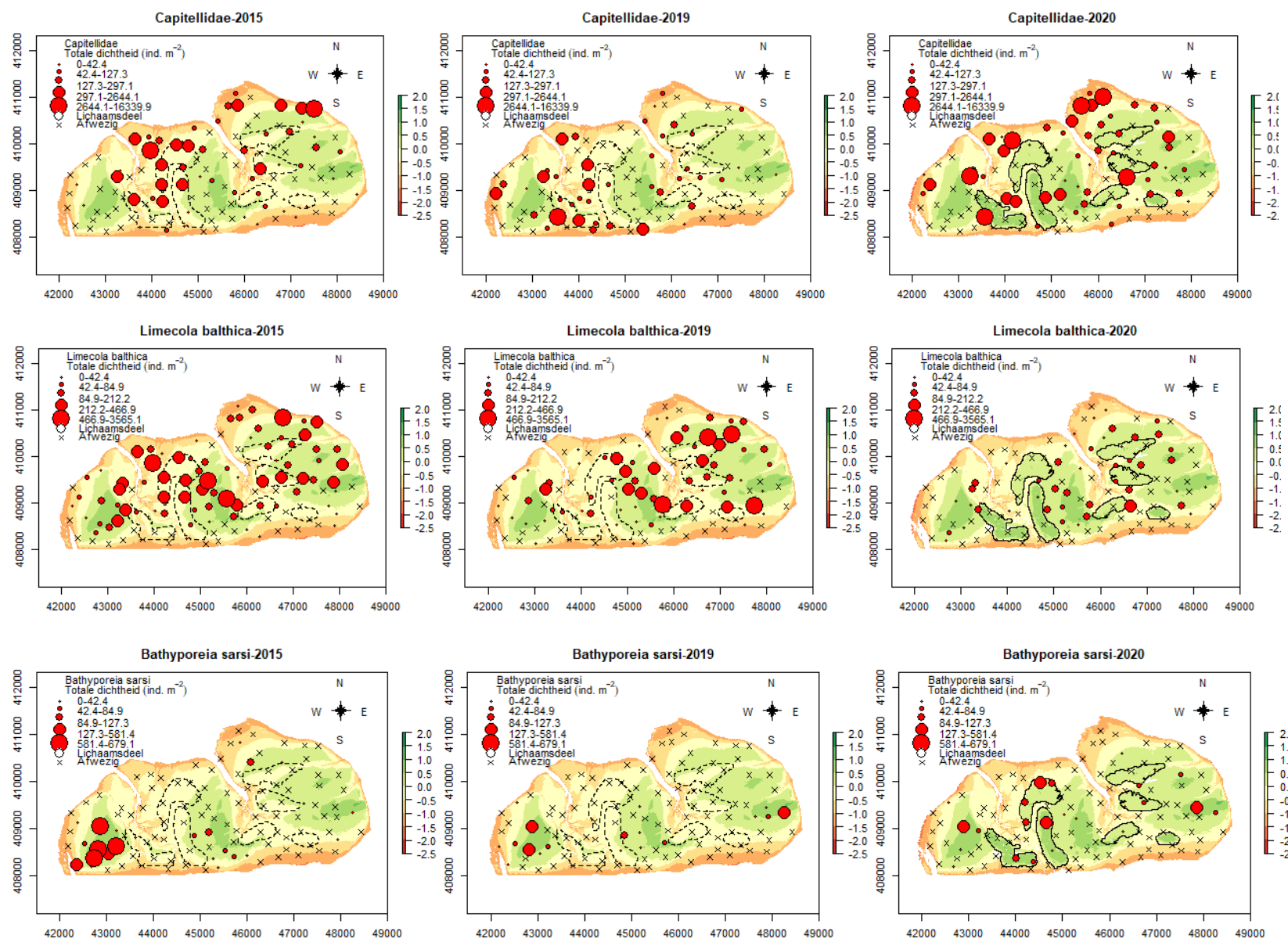

Figuur 6-27 Verspreidingskaart van Capitellidae, Limecola balthica, en Bathyporeia sarsi elegans dichtheden op de Roggenplaat in 2015, 2019 en 2020. Achtergrondkaart: LiDAR 2019 en 2020.

\subsubsection{Resultaten suppleties}

Inzoomend op de suppletie-elementen zien we dat suppletie-element 4, 5 en 7, zowel de laagste soortendichtheid als soortenrijkdom heeft (Figuur 6-28). Suppletie-element 2 en 6 hebben gemiddeld de hoogste soortendichtheid en suppletie-element 3 en 6 de hoogste soortenrijkdom (Tabel 7). Suppletie 4, 5 en 7 bestaan uit een dikkere suppletie laag en een hogere bodemligging in vergelijking met de andere suppletie-elementen.

Totale Dichtheid-2020

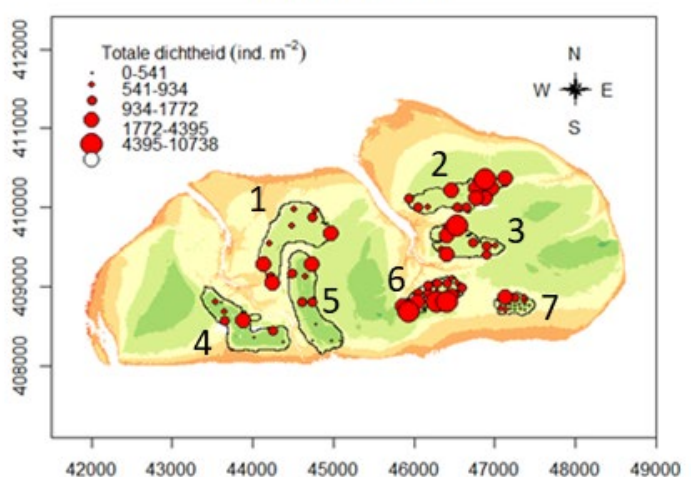

Soortenrijkdom-2020

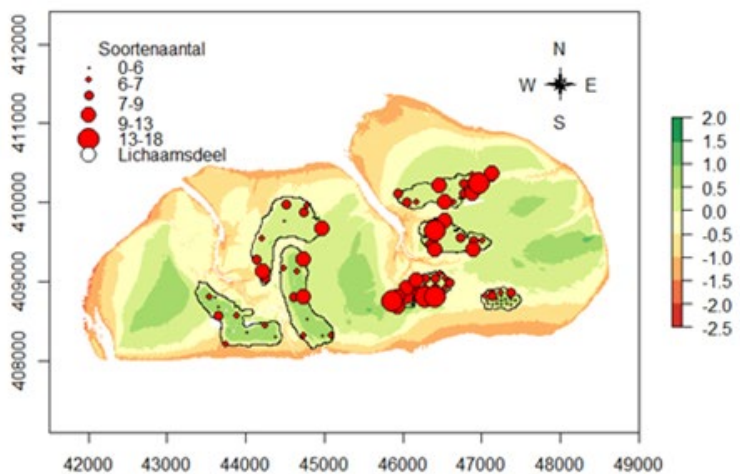

Figuur 6-28 Totale dichtheid (individuen $\mathrm{m}^{-2}$ ) en soortenrijkdom (aantal soorten) per bemonsteringslocatie. Achtergrondkaart: LiDAR RWS 2020. 
Tabel 7 Gemiddelde soortenrijkdom, dichtheid en biomassa aangetroffen in de monsters genomen op elk afzonderlijke suppletie-element en de Roggenplaat tijdens de 2020 bemonstering. Grijze rijen geven dikkere suppleties weer.

\begin{tabular}{|c|c|c|c|c|c|c|c|c|c|c|}
\hline & \multicolumn{3}{|c|}{ Soortenrijkdom } & \multicolumn{3}{|c|}{ Dichtheid [n/m2] } & \multicolumn{3}{|c|}{ Biomassa [] } & \\
\hline Suppletie & $\mu+s d$ & $\min$ & $\max$ & $\mu+S d$ & Min & Max & $\mu+s d$ & $\min$ & Max & $\mathrm{N}$ \\
\hline 1 & $8+2$ & 4 & 11 & $1556+1054$ & 679 & 3608 & & & & 9 \\
\hline 2 & $9+2$ & 6 & 13 & $2323+1376$ & 722 & 5008 & & & & 12 \\
\hline 3 & $10+2$ & 5 & 14 & $1825+1333$ & 806 & 4626 & & & & 9 \\
\hline 4 & $6+2$ & 3 & 8 & $962+769$ & 170 & 2462 & & & & 9 \\
\hline 5 & $7+3$ & 3 & 10 & $1061+1007$ & 255 & 3480 & & & & 9 \\
\hline 6 & $10+3$ & 6 & 18 & $2082+2446$ & 467 & 10738 & & & & 20 \\
\hline 7 & $5+2$ & 2 & 9 & $520+430$ & 85 & 2037 & & & & 20 \\
\hline $\begin{array}{l}\text { Roggenplaat } \\
2020\end{array}$ & $11+5$ & 1 & 27 & $4161+5495$ & 42 & 41465 & & & & 97 \\
\hline
\end{tabular}

Hieronder beschrijven we voor een aantal op de suppletie aangetroffen soorten (Tabel 8, Figuur 6-29) hun voorkomen op de gehele Roggenplaat of verschillen tussen suppletie-elementen. Voor verschillen tussen suppletie-elementen en de gehele Roggenplaat, worden van de 113 bemonsterde locaties in 2020 alleen punten gelegen buiten de contouren van de suppletie meegenomen $(n=97)$.

In 2020 is de borstelworm Nepthys cirossa op alle suppleties, behalve element 4 en 5, aangetroffen (Figuur 6-37). Eerder kwam deze soort nauwelijks voor. Deze soort heeft een voorkeur middel grof sediment en locaties met verhoogde verstoring, wat mogelijks hun voorkomen op de suppleties kan verklaren. Op suppletie 7 is het tevens de soort met de hoogste gemiddelde dichtheid (189 \pm 7 ind $/ \mathrm{m}^{2}$, zie Tabel 8 ). Pygospio elegenas is toegenomen ten opzichte van 2015 en komt iets meer voor op de suppleties (suppleties: $192 \pm 347$; Roggenplaat: $88 \pm 128 \mathrm{ind} / \mathrm{m}^{2}$ ) en laat, behalve op suppletie 2, een gemiddelde minimale dichtheid van $100 \mathrm{ind} / \mathrm{m}^{2}$ zien, waarbij de hoogste dichtheid geobserveerd is op suppletie $4(410 \pm 523)$. Urothoe poseidonis komt gemiddeld in hogere dichtheden voor op de Roggenplaat (suppleties: $231 \pm 532$; Roggenplaat: 900 $\left.\pm 1258 \mathrm{ind} / \mathrm{m}^{2}\right)$. Dit verschil is echter minder groot voor suppletie $2\left(608 \pm 886 \mathrm{ind} / \mathrm{m}^{2}\right)$ en suppletie 3 (406 $\left.\pm 691 \mathrm{ind} / \mathrm{m}^{2}\right)$. Scoloplos armiger wordt in vergelijkbare dichtheden aangetroffen op de suppletie (297 $\pm 427 \mathrm{ind} / \mathrm{m}^{2}$ ) en de Roggenplaat (361 $\left.\pm 491 \mathrm{ind} / \mathrm{m}^{2}\right)$. De soort komt vooral voor op de oostelijke dunnere suppleties (2,3 en 6). Op suppletie 2 troffen we hem op alle locaties aan met een gemiddelde dichtheid ( $874 \pm 600 \mathrm{ind} / \mathrm{m}^{2}$ ) twee keer zo hoog als geobserveerd op de Roggenplaat. Opvallend was dat deze soort in 2020 gemiddeld minder voorkomt dan tijdens de T0 metingen. Bathyporeia sarsi komt op de suppletie $\left(128 \pm 192 \mathrm{ind} / \mathrm{m}^{2}\right.$ ) vaker en in hogere dichtheden voor dan op de Roggenplaat $\left(11 \pm 39 \mathrm{ind} / \mathrm{m}^{2}\right)$. Het is tevens een van de weinige soorten die frequent op suppletie 4 en 7 wordt geobserveerd. In voorgaande jaren werd deze soort op hooggelegen locaties in het westen van de Roggenplaat gevonden. Ook Bathyporeia pilosa wordt op suppletie $1\left(311 \pm 842 \mathrm{ind} / \mathrm{m}^{2}\right)$ en $4\left(160 \pm 326 \mathrm{ind} / \mathrm{m}^{2}\right)$ in relatief hoge dichtheden gevonden, terwijl de gemiddelde dichtheid van deze soort op de rest van de Roggenplaat laag is ( $2 \pm 18 \mathrm{ind} / \mathrm{m}^{2}$ ). Aphelochaeta spp. laat op de suppletie lagere dichtheden zien dan op de Roggenplaat (suppleties: $28 \pm 73$; Roggenplaat: $589 \pm 1291$ ind $/ \mathrm{m}^{2}$ ). Hoeveelheden Limecola balthica op dunne suppleties (2, 3 en 6 ) lijken hetzelfde te zijn als op de rest van de Roggenplaat. In de tijd lijkt er een daling gaande te zijn voor deze soort op de Roggenplaat (Tabel 7). Hoewel Capitellidae iets lijkt te zijn toegenomen, en in 2020 tot een van hoogste in dichtheid aangetroffen soorten behoort, wordt deze soort maar enkele keren op suppleties geobserveerd (suppleties: $19 \pm 73$; Roggenplaat: $509 \pm 1896 \mathrm{ind} / \mathrm{m}^{2}$ ). Andere soorten die in veel mindere maten voorkomen op de suppleties zijn: Oligochaeta (suppleties: $112 \pm 711$; Roggenplaat: $463 \pm 1731$ ind $/ \mathrm{m}^{2}$ ), welk op suppletie 6 wel vergelijkbare dichtheden vertoont en Aphelochaeta spp. (suppleties: $28 \pm 73$; Roggenplaat: $589 \pm 1291 \mathrm{ind} / \mathrm{m}^{2}$ ). 
Wadpier, Arenicola marina, dichtheden zijn in het veld middels kwadrant tellingen verkregen. Voor aanleg kwamen grote wadpierhoopjes verspreid over de gehele Roggenplaat voor, met uitzondering in het westen, noorden en in laag gelegen gebieden (Figuur 6-31). Kleine wadpierhoopjes werden minder vaak geobserveerd en kwamen vooral voor in het midden van de Roggenplaat. Na aanleg zijn in het noorden van de Roggenplaat meer kleine wadpierhoopjes geobserveerd. Verder vinden we buiten de suppletie-elementen geen opvallende veranderingen. Op de suppleties worden meer kleine dan grote wadpierhoopjes aangetroffen. Op suppletie-element 4 en 7 zijn, maar heel weinig hoopjes van beide formaten aangetroffen. Op suppletie 6 komen er in het noorden kleine hoopjes en in het zuiden grote hoopjes voor.

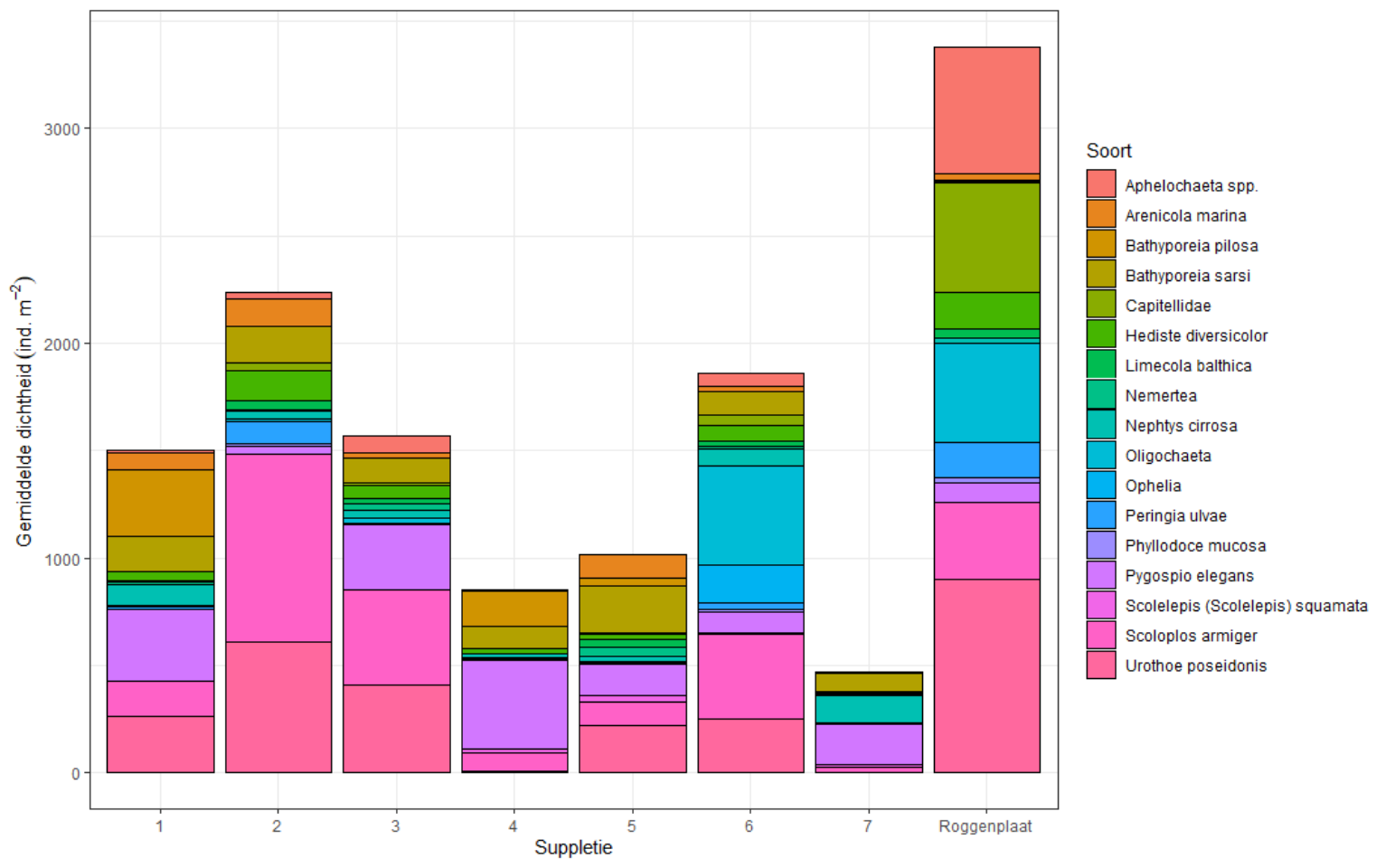

Figuur 6-29 Gemiddelde dichtheden (aantal individuen per $\mathrm{m}^{2}$ ) van de belangrijkste soorten aangetroffen op alle afzonderlijke suppleties en de hele Roggenplaat (excl. monsters gelegen binnen de contouren van de suppleties) in 2020 (zie ook Tabel 8 ). Niet alle soorten worden weergegeven. De hoogte van de bars geeft dus niet de totale dichtheid weer. 

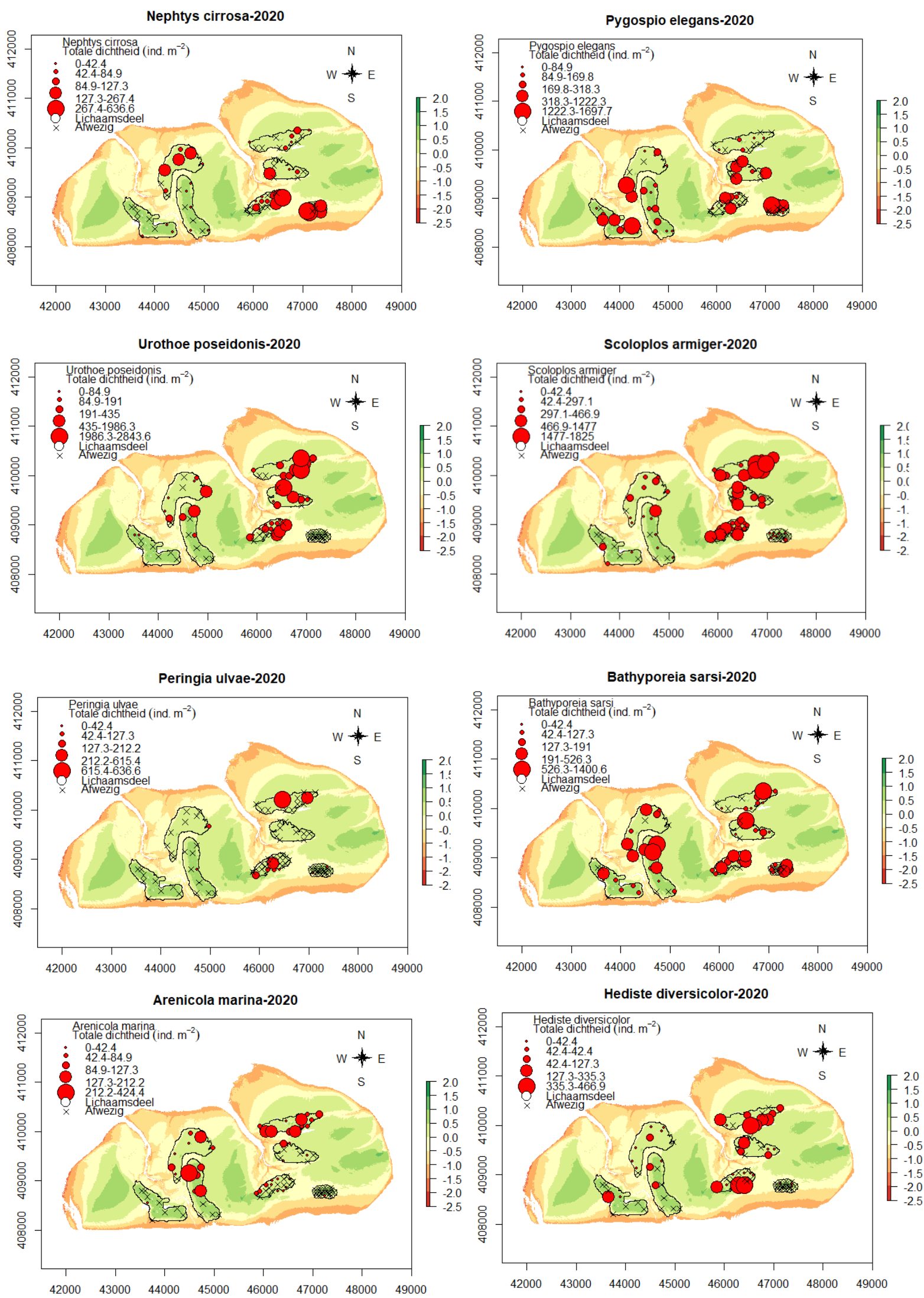

Figuur 6-30 Verspreiding van enkele belangrijke soorten op de afzonderlijke suppletie-elementen aangetroffen tijdens de 2020 bemonsteringen. 

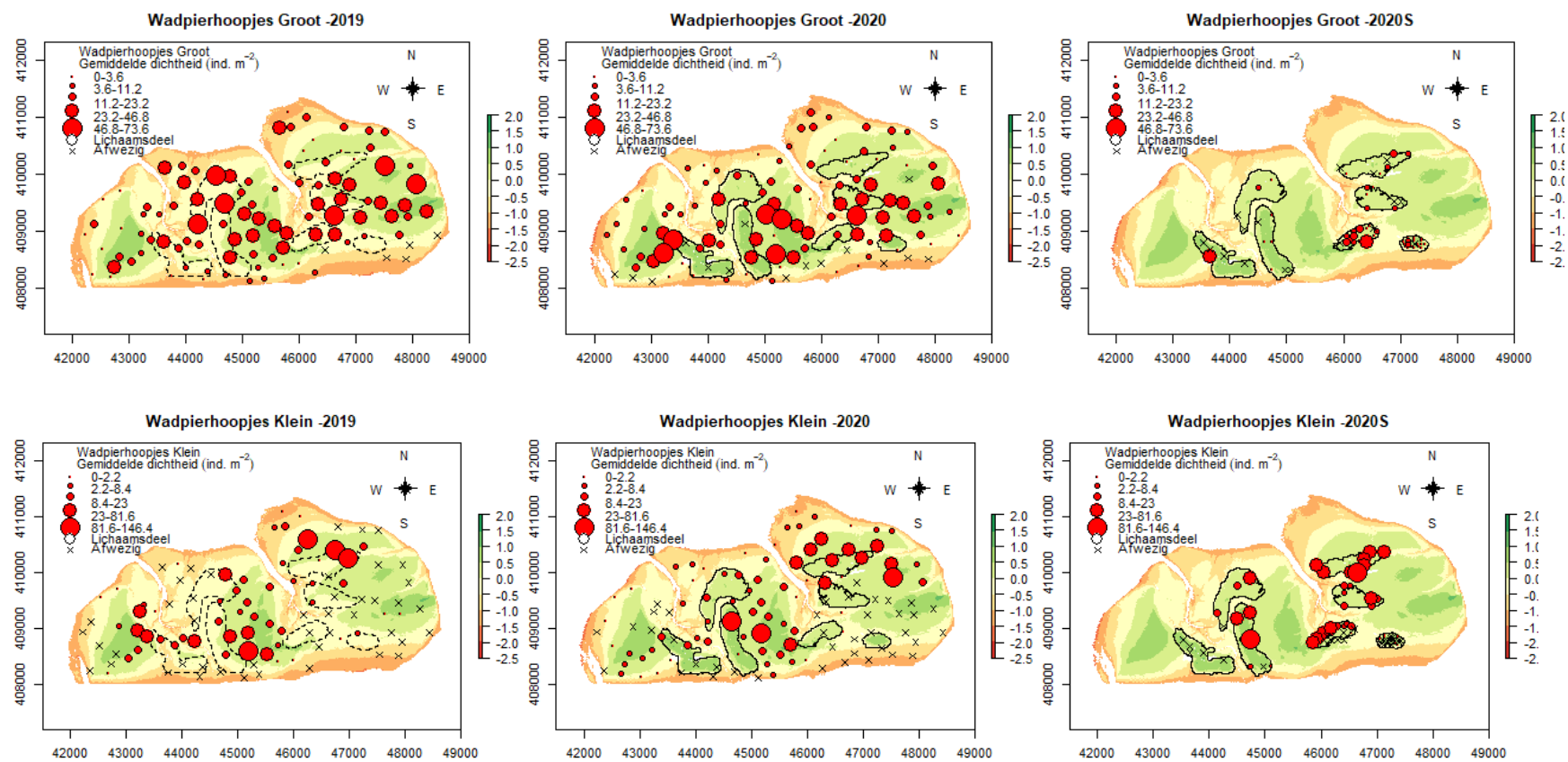

Figuur 6-31 Verspreiding van gemiddelde tellingen van kleine en grote wadpierhoopjes op Roggenplaat in 2019 en 2020 en op de suppleties in 2020.

\subsubsection{Resultaten Multivariate analyse}

Veranderingen in bodemdiergemeenschap over de tijd zijn onderzocht middels een multivariate analyse. De nMDS is uitgevoerd op basis van dichtheden van 64 geselecteerde taxa geobserveerd in 338 monsters genomen in 2015, 2019 en 2020. Hierbij werden de additionele suppletiemonsters genomen in 2020 niet meegenomen. De $95 \%$ betrouwbaarheid intervallen van de bemonsteringsjaren overlappen en er is geen verschil in gemiddelde soortensamenstelling (Figuur 6-32). De 2D stress voor het model is 0.238 , wat relatief hoog is, een driedimensionale ordinatie gaf een lagere stress van 0.192 , maar liet ook geen verschil in de benthische gemeenschap tussen de jaren zien.

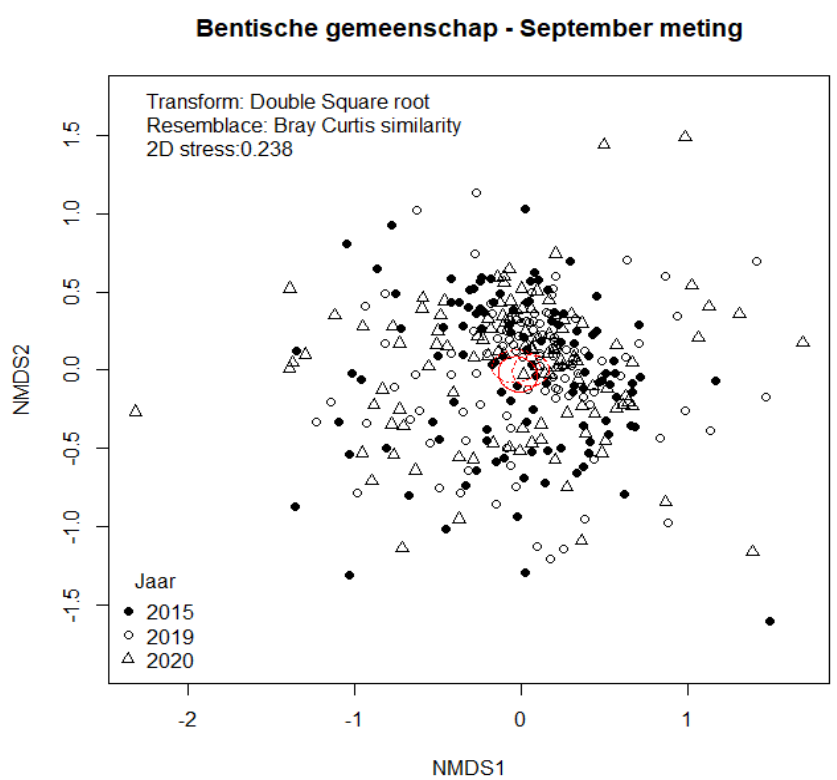

Figuur 6-32 nMDS plot met de relatieve positie van monsters genomen op de Roggenplaat in september tijdens de T0 (2015: $n=113 ; 2019 \mathrm{n}=112)$ en T1 (2020: $n=113$ ) bemonstering. Rode ellipsen geven het $95 \%$ betrouwbaarheidsinterval per jaar weer. 
Voor alle monsterpunten genomen in 2020, inclusief de extra suppletie-punten, is een aparte nMDS uitgevoerd op basis van de dichtheden van 42 geselecteerde taxa. Hierbij is een verschil te zien tussen de soortensamenstelling op de suppleties en buiten de suppleties (Figuur 6-33). Soorten zoals Pygospio elegans, Bathyporeia spp., Nepthys cirrosa en Scololepis squamata nemen een groter percentage van de totale dichtheid op de suppleties in beslag dan op de rest van de Roggenplaat (zie Tabel 8). De relatieve positie van deze soorten ligt in de Figuur 6-33 dan ook dichtbij de suppletie monsters.
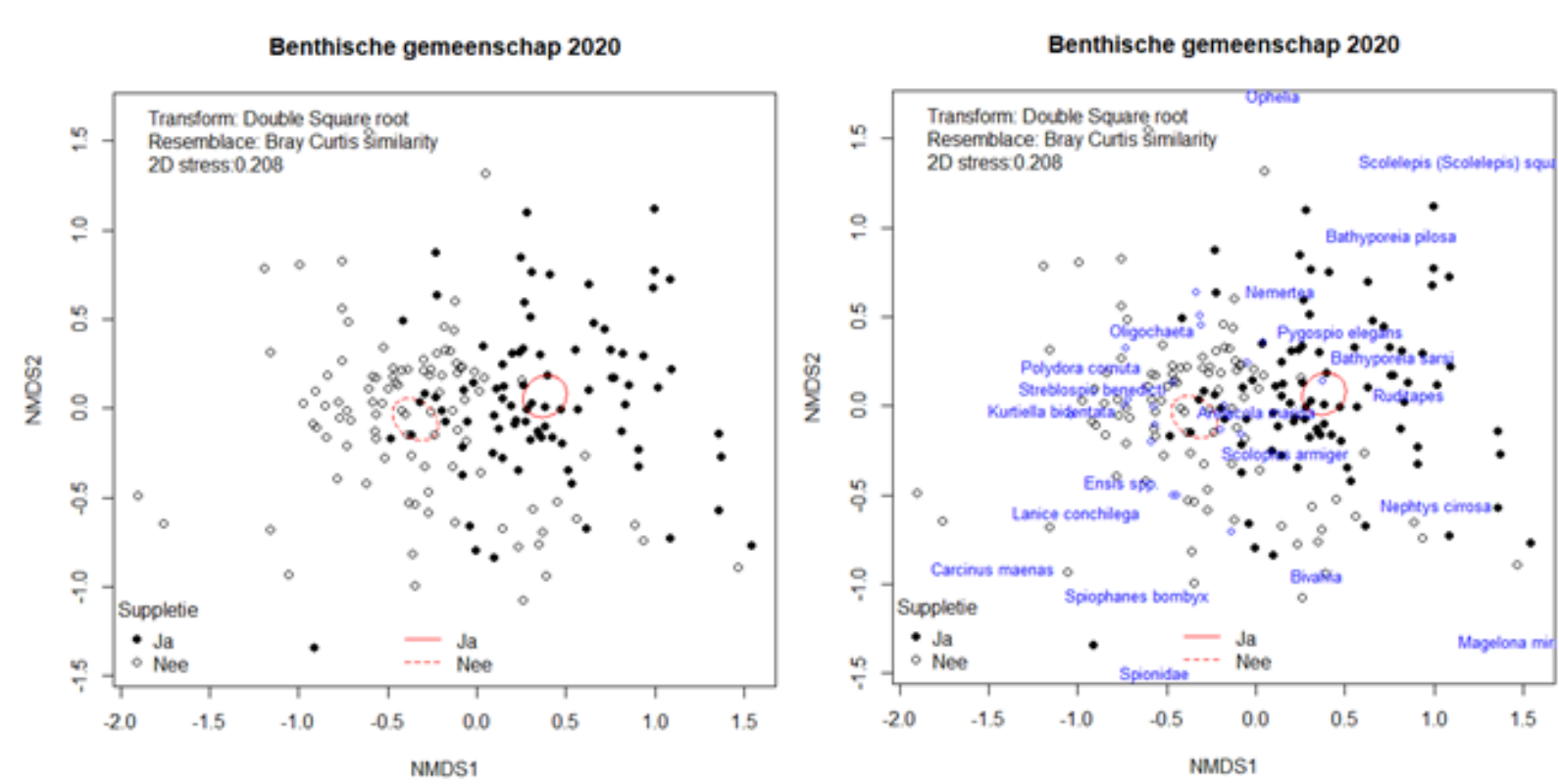

Figuur 6-33 nMDS plot welk de relatieve positie weergeeft van monster genomen op de suppletie $(n=88)$ en buiten de suppletie $(n=97)$ tijdens alle bemonsteringen in 2020. Rode ellipsen geven de $95 \%$ betrouwbaarheid intervallen voor beide groepen weer.

Tot slot is er een nMDS uitgevoerd op alleen de suppletie locaties, waarbij de dichtheden van 28 geselecteerde soorten werden gebruikt. Figuur 6-34 geeft hierbij de resultaten gegroepeerd op dikke/dunne suppleties en Figuur 6-35 gebaseerd op elke individuele suppletie. Tussen de $95 \%$ betrouwbaarheidsintervallen van dikke en dunne suppleties zit geen overlap. Op dikke suppletie-elementen wordt een andere soortensamenstelling aangetroffen dan op dunne suppletie-elementen. Gegroepeerd per suppletie laat zien dat suppletie 7 de meest afwijkende soortensamenstelling heeft. Binnen suppletie 4 zit veel variatie en er is dan ook overlap in soortensamenstelling met zowel dikke als dunne suppleties. 

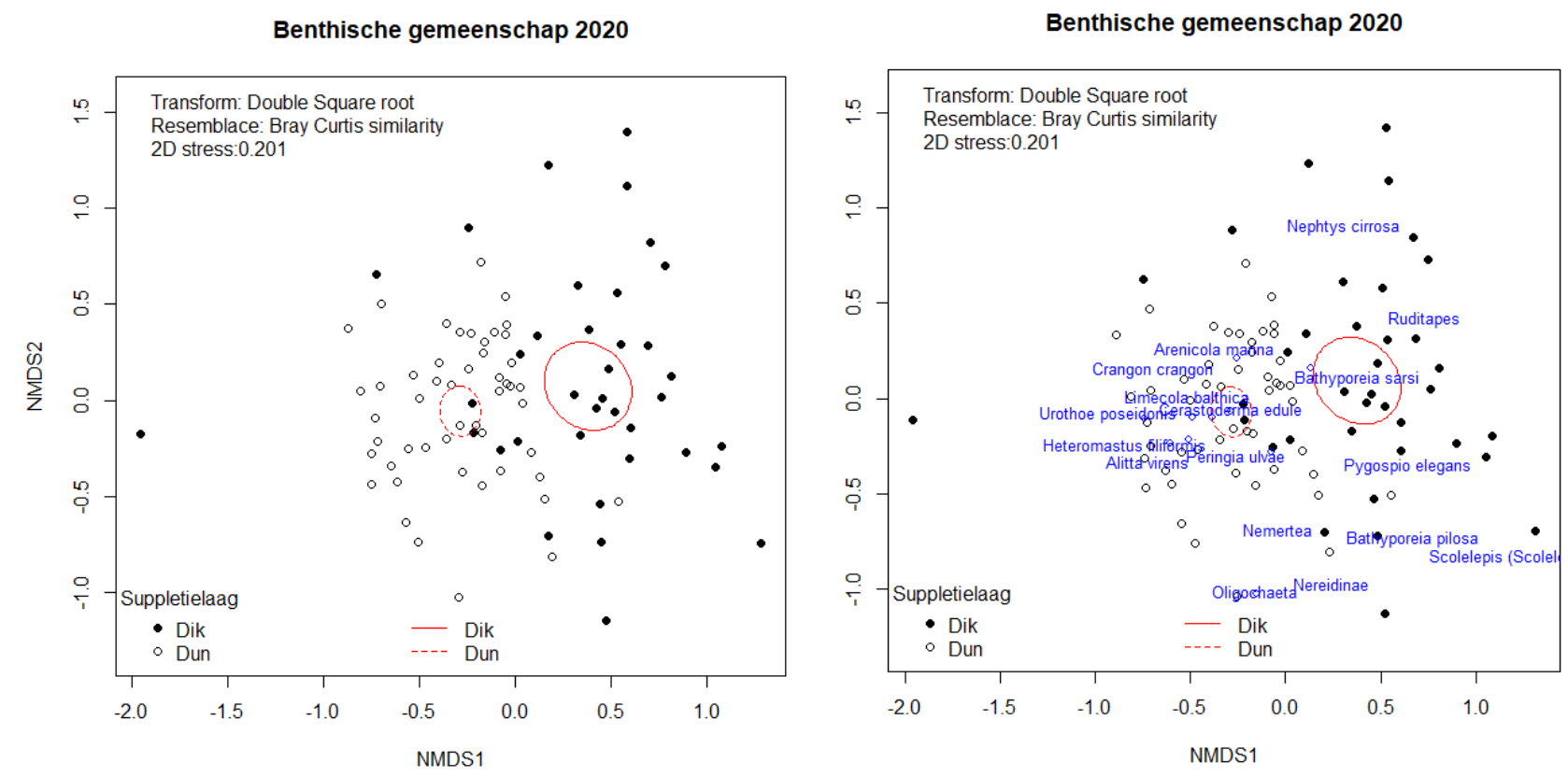

Figuur 6-34 nMDS plot van alle monsters genomen op de suppletie in $2020(n=88)$. Rode ellipsen geven de $95 \%$ CI van de twee groepen weer. Rechts geeft ook de relatieve positie van belangrijke soorten weer.
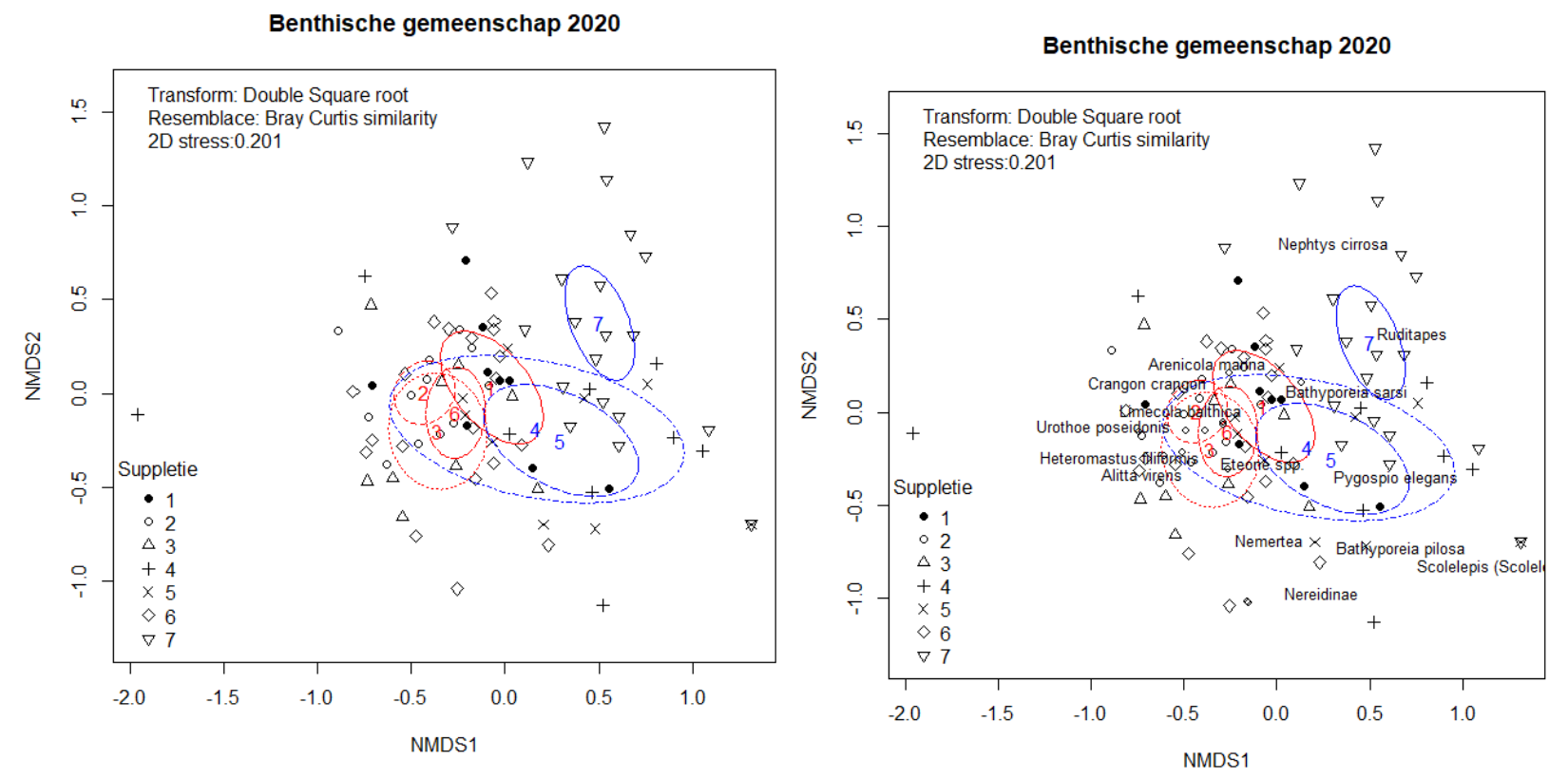

Figuur 6-35 nMDS plot van alle monsters genomen op de suppletie in $2020(n=88)$, rode ellipsen geven de $95 \%$ CI voor dunne suppleties weer en blauwe ellipsen voor dikke suppleties. Rechts zijn ook de relatieve posities van belangrijke soorten weergegeven. 
Tabel 8 Voorkomen en gemiddelde dichtheden (aantal individuen per $\mathrm{m}^{2}$ ) per aangetroffen taxon voor alle afzonderlijke suppleties en de hele Roggenplaat (excl. Monsters gelegen binnen de contouren van de suppleties) in 2020. Weergeven zijn de belangrijkste soorten, een overzicht met alle soorten is te zien in Bijlage 5. Soorten staan geordend op alfabetische volgorde. Grijze cellen geven aan wanneer soorten een hogere dichtheid dan 100 ind. $/ \mathrm{m}^{2}$ of een voorkomen van $70 \%$ of hoger vertonen.

\begin{tabular}{|c|c|c|c|c|c|c|c|c|c|c|c|c|c|c|c|c|c|c|c|c|c|c|c|c|}
\hline \multirow[b]{2}{*}{ Soort } & \multicolumn{3}{|c|}{$\begin{array}{c}\text { Suppletie } 1 \\
n=9\end{array}$} & \multicolumn{3}{|c|}{$\begin{array}{c}\text { Suppletie } 2 \\
n=12\end{array}$} & \multicolumn{3}{|c|}{$\begin{array}{c}\text { Suppletie } 3 \\
n=9\end{array}$} & \multicolumn{3}{|c|}{$\begin{array}{c}\text { Suppletie } 4 \\
n=9\end{array}$} & \multicolumn{3}{|c|}{$\begin{array}{c}\text { Suppletie } 5 \\
n=9\end{array}$} & \multicolumn{3}{|c|}{$\begin{array}{c}\text { Suppletie } 6 \\
n=20\end{array}$} & \multicolumn{3}{|c|}{$\begin{array}{c}\text { Suppletie } 7 \\
n=20\end{array}$} & \multicolumn{3}{|c|}{$\begin{array}{c}\text { Roggenplaat } \\
n=97\end{array}$} \\
\hline & $\%$ & $\mu$ & sd & $\%$ & $\mu$ & sd & $\%$ & $\mu$ & sd & $\%$ & $\mu$ & $\mathrm{Sd}$ & $\%$ & $\mu$ & sd & $\%$ & $\mu$ & sd & $\%$ & $\mu$ & sd & $\%$ & $\mu$ & $s d$ \\
\hline $\begin{array}{l}\text { Aphelochaeta } \\
\text { spp. }\end{array}$ & 22 & 14 & \pm 30 & 17 & 32 & \pm 87 & 44 & 80 & \pm 123 & 0 & & & 0 & & & 55 & 57 & \pm 96 & 5 & 2 & \pm 10 & 57 & 589 & \pm 1291 \\
\hline $\begin{array}{l}\text { Arenicola } \\
\text { marina }\end{array}$ & 89 & 80 & \pm 62 & 100 & 124 & \pm 56 & 44 & 28 & \pm 42 & 11 & 5 & \pm 14 & 56 & 109 & \pm 141 & 50 & 28 & \pm 32 & 5 & 2 & \pm 10 & 53 & 34 & \pm 44 \\
\hline $\begin{array}{l}\text { Bathyporeia } \\
\text { pilosa }\end{array}$ & 22 & 311 & \pm 842 & 0 & & & 0 & & & 33 & 160 & \pm 321 & 33 & 38 & \pm 83 & 0 & & & 10 & 6 & \pm 21 & 2 & 2 & \pm 18 \\
\hline $\begin{array}{l}\text { Bathyporeia } \\
\text { sarsi }\end{array}$ & 78 & 160 & \pm 123 & 75 & 173 & \pm 390 & 67 & 113 & \pm 204 & 67 & 104 & \pm 146 & 78 & 217 & \pm 235 & 90 & 106 & \pm 89 & 70 & 85 & \pm 92 & 13 & 11 & \pm 39 \\
\hline Capitellidae & 11 & 5 & \pm 14 & 42 & 35 & \pm 57 & 11 & 14 & \pm 42 & 0 & & & 11 & 5 & \pm 14 & 35 & 49 & \pm 141 & 5 & 2 & \pm 10 & 57 & 509 & \pm 1896 \\
\hline $\begin{array}{l}\text { Hediste } \\
\text { diversicolor }\end{array}$ & 78 & 42 & \pm 37 & 75 & 138 & \pm 128 & 67 & 57 & \pm 60 & 22 & 24 & \pm 57 & 33 & 24 & \pm 37 & 60 & 72 & \pm 128 & 15 & 6 & \pm 16 & 70 & 166 & \pm 234 \\
\hline $\begin{array}{l}\text { Limecola } \\
\text { balthica }\end{array}$ & 11 & 5 & \pm 14 & 67 & 42 & \pm 41 & 44 & 28 & \pm 37 & 11 & 5 & \pm 14 & 44 & 38 & \pm 69 & 45 & 23 & \pm 32 & 15 & 6 & \pm 16 & 43 & 44 & \pm 66 \\
\hline Nemertea & 22 & 9 & \pm 19 & 17 & 7 & \pm 17 & 33 & 28 & \pm 56 & 0 & & & 22 & 42 & \pm 90 & 25 & 13 & \pm 24 & 5 & 2 & \pm 10 & 8 & 4 & \pm 14 \\
\hline $\begin{array}{l}\text { Nephtys } \\
\text { cirrosa }\end{array}$ & 78 & 99 & \pm 93 & 50 & 35 & \pm 44 & 33 & 33 & \pm 59 & 33 & 14 & \pm 21 & 56 & 24 & \pm 22 & 65 & 83 & \pm 100 & 90 & 127 & \pm 146 & 26 & 21 & \pm 49 \\
\hline Oligochaeta & 11 & 5 & \pm 14 & 17 & 14 & \pm 38 & 44 & 28 & \pm 42 & 22 & 9 & \pm 19 & 22 & 9 & \pm 19 & 40 & 461 & \pm 1466 & 0 & & & 49 & 463 & \pm 1731 \\
\hline Ophelia & 0 & & & 0 & & & 0 & & & 11 & 5 & \pm 14 & 0 & & & 10 & 172 & \pm 720 & 0 & & & 0 & & \\
\hline Peringia ulvae & 11 & 14 & \pm 42 & 17 & 103 & \pm 240 & 0 & & & 0 & & & 11 & 5 & \pm 14 & 25 & 36 & \pm 73 & 10 & 4 & \pm 13 & 34 & 162 & \pm 366 \\
\hline $\begin{array}{l}\text { Phyllodoce } \\
\text { mucosa }\end{array}$ & 0 & 0 & \pm 0 & 33 & 14 & \pm 21 & 11 & 5 & \pm 14 & 0 & & & 0 & & & 15 & 6 & \pm 16 & 0 & & & 20 & 27 & \pm 100 \\
\hline $\begin{array}{l}\text { Pygospio } \\
\text { elegans }\end{array}$ & 78 & 330 & \pm 538 & 42 & 35 & \pm 57 & 56 & 302 & \pm 359 & 78 & 410 & \pm 523 & 100 & 146 & \pm 77 & 50 & 100 & \pm 194 & 60 & 189 & \pm 394 & 59 & 88 & \pm 128 \\
\hline $\begin{array}{l}\text { Scolelepis } \\
\text { squamata }\end{array}$ & 11 & 5 & \pm 14 & 0 & & & 0 & & & 44 & 24 & \pm 31 & 33 & 28 & \pm 48 & 10 & 4 & \pm 13 & 20 & 15 & \pm 40 & 0 & & \\
\hline $\begin{array}{l}\text { Scoloplos } \\
\text { armiger }\end{array}$ & 89 & 160 & \pm 130 & 100 & 874 & \pm 600 & 89 & 448 & \pm 288 & 33 & 80 & \pm 161 & 67 & 113 & \pm 261 & 90 & 399 & \pm 430 & 40 & 23 & \pm 40 & 85 & 361 & \pm 491 \\
\hline $\begin{array}{l}\text { Urothoe } \\
\text { poseidonis }\end{array}$ & 67 & 264 & \pm 590 & 83 & 608 & \pm 886 & 78 & 406 & \pm 691 & 22 & 9 & \pm 19 & 33 & 217 & \pm 515 & 70 & 248 & \pm 444 & 0 & & & 73 & 900 & \pm 1258 \\
\hline
\end{tabular}




\subsubsection{Resultaten veldscreening}

De snelle veldscreening toont dat de gemiddelde geobserveerde soortenrijkdom in het bemonsterd gebied in 2020 gedaald is ten opzichte van 2017 (Tabel 9 en Figuur 6-36). In Bijlage 6 is weergeven welke soorten er bij het berekenen van de soortenrijkdom zijn meegeteld. Suppletie 4 heeft de laagste soortenrijkdom gevolgd door suppletie 5 en 7 . In Figuur 6-36 is te zien dat deze afname vooral in het midden van deze suppleties plaatsvindt. Suppletie 4 en 5 bestaan uit een dikke suppletielaag. De kwantitatieve bemonstering laat ook zien dat deze suppleties de laagste soortenrijkdom bevatten. Voor suppletie 7 zien we een klein verschil in soortenrijkdom tussen de veldscreening en kwantitatieve bemonstering, terwijl voor de andere suppletie-elementen deze sterk afwijken (zie Tabel 7 en Tabel 9). Opvallend is de toename in soortenrijkdom op suppletie 2 en 3 in het gebied rond de afwatering van het Middengeultje. Aan de westkant van suppletie 3 wordt een lagere soortenrijkdom gevonden dan aan de oostkant. De kwantitatieve bemonstering laat juist het tegenovergestelde zien (Figuur 6-28).

Tabel 9 soortenrijkdom voor en na aanleg van de suppleties per suppletie element.

\begin{tabular}{|l|l|l|}
\hline & T0 & T1 \\
\hline Suppletie 1 & $6.1 \pm 2.0$ & $3.8 \pm 2.1$ \\
\hline Suppletie 2 & $5.2 \pm 2.8$ & $4.9 \pm 1.7$ \\
\hline Suppletie 3 & $4.9 \pm 2.7$ & $4.6 \pm 1.9$ \\
\hline Suppletie 4 & $3.6 \pm 1.6$ & $1.2 \pm 1.9$ \\
\hline Suppletie 5 & $5.2 \pm 2.2$ & $2.6 \pm 2.0$ \\
\hline Suppletie 6 & $7.4 \pm 2.1$ & $5.2 \pm 2.9$ \\
\hline Suppletie 7 & - & $3.5 \pm 1.7$ \\
\hline Totaal & $5.2 \pm 2.4$ & $4.7 \pm 2.6$ \\
\hline
\end{tabular}

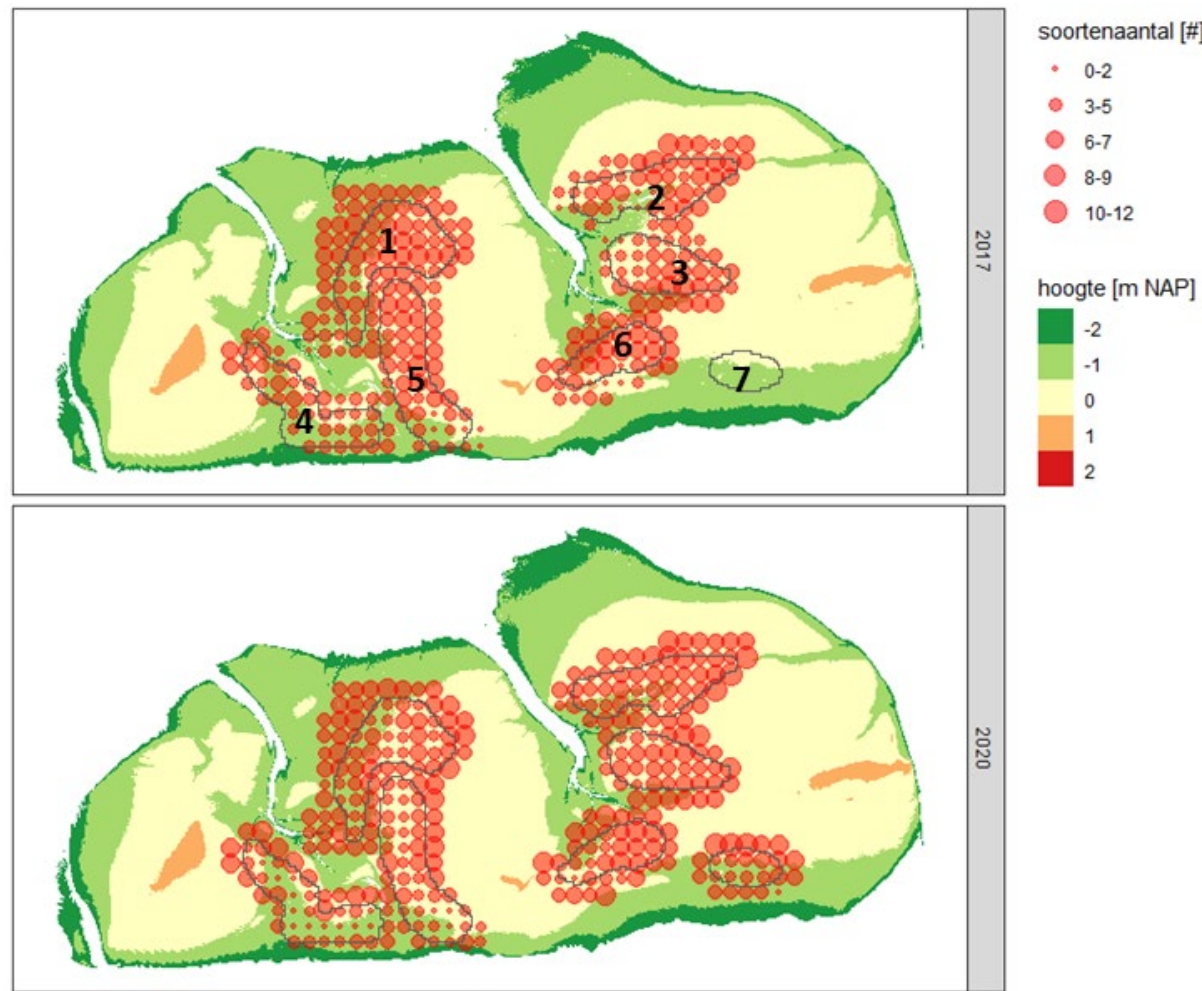

Figuur 6-36 Overzicht van soortenrijkdom, berekend op basis van in alle jaren gemeten soorten, geobserveerd per locatie tijdens de kwalitatieve benthos survey van 2017 en 2020. Achtergrondkaart: LiDAR RWS 2018 
Abiotische kenmerken en veelvoorkomende soorten en soorten met een duidelijk verspreidingspatroon zijn weergeven in Figuur 6-37 en Figuur 6-31. Andere meer verspreid voorkomende of zeldzamere soorten (eg. Nereis) zijn opgenomen in Bijlage 6. Voor de aanleg van de suppleties, kwamen wadpieren en kokkels zeer vaak voor. Alleen in het zuidelijke deel van de Roggenplaat en ten oosten van het Middengeultje kwamen ze minder vaak voor. Na de aanleg waren kokkels op de meeste suppleties grotendeels afwezig, op het oostelijke deel van suppletie 3 en om de suppleties heen, kwamen ze nog wel voor. Wadpieren zijn overal behalve op suppletie 4 en op de zuidelijke kant aanwezig. Voor aanleg kwam de kokkerworm lanice en de wapenworm in bepaalde gebieden veel voor. Sinds de aanleg is Lanice op alle suppleties afwezig. De wapenworm komt op suppletie 1 juist vaker voor in 2020 en is net als veel andere soorten afwezig op suppletie 4. Op de oostelijke suppleties lijkt de wapenworm zich in stand te hebben gehouden. Verder waren wadslakjes alleen frequent aanwezig in het gebied waar suppleties 2 en 6 gepland stonden en heteromastus alleen in het noorden van het gebied van suppletie 1 . Wadslakjes komen in 2020 minder voor op suppletie 2 en heteromastus is verdwenen van het noorden van suppletie 1.

Op plekken waar in 2017 golfribbels voorkwamen, een indicatie voor grotere stroomsnelheden, waren diatomeeën vaak afwezig. Dit is vooral te zien aan de westkant van de Roggeplaat. Na aanleg zijn diatomeeën op alle suppleties aangetroffen en komen ook golfribbels vaak op de suppleties voor. Echter op de punten direct grenzend aan de suppleties komen geen golfribbels voor. 


\section{hoogte [m NAP] $\square-2 \quad-1 \quad 0 \quad-1 \square 2$ Aanwezig $\bigcirc$ ja $\bigcirc$ nee $\bigcirc$ NA}
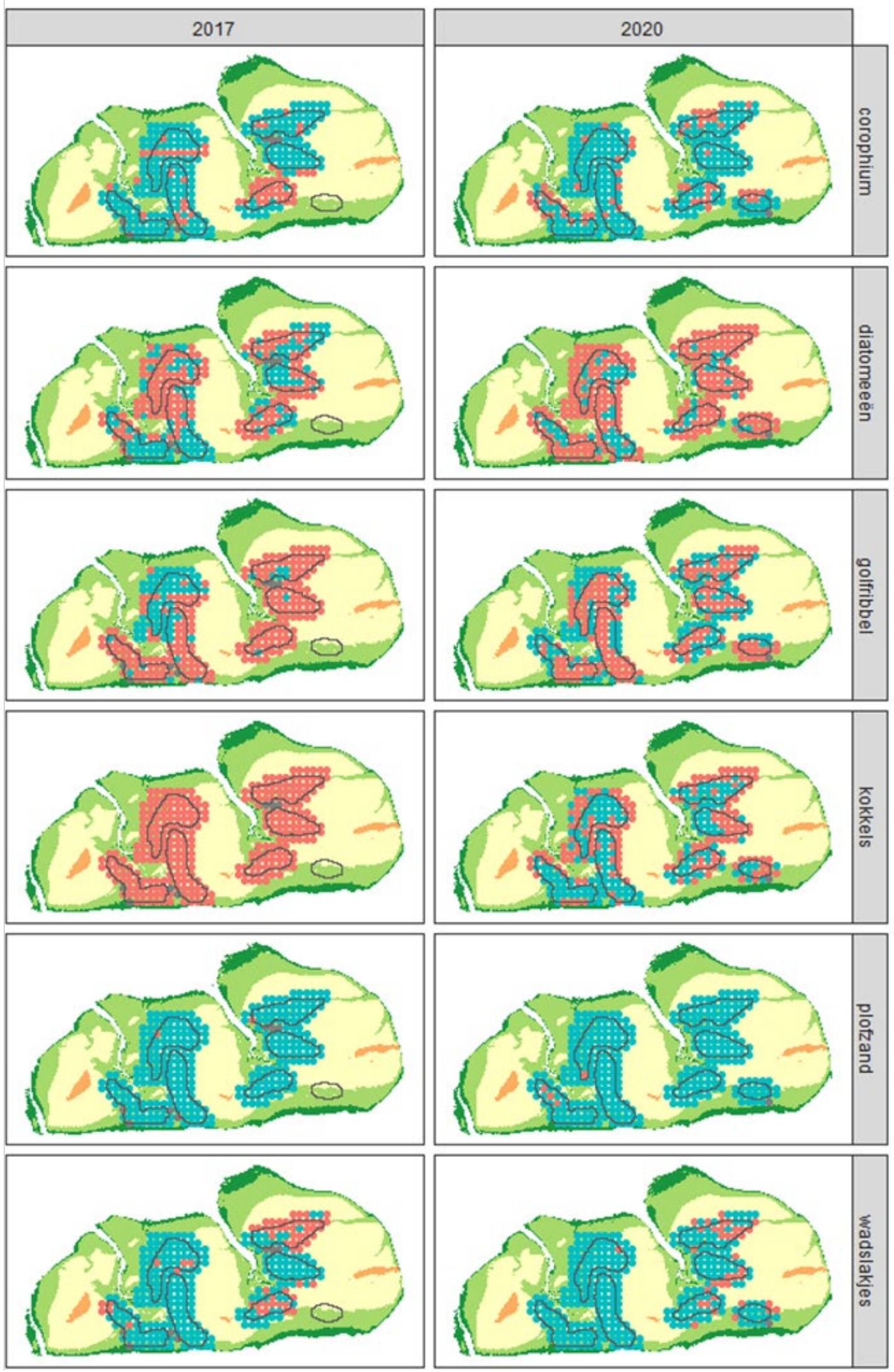

Figuur 6-37 Overzicht van locaties waar verschillende soorten/abiotische kenmerken tijdens de snelle veldscreening in 2017 en 2020 zijn aangetroffen. Achtergrondkaart: LiDAR RWS 2018 


\section{hoogte [m NAP] $\square-2 \quad-1 \quad 0 \quad \begin{aligned} & -1 \\ & \square\end{aligned}$}
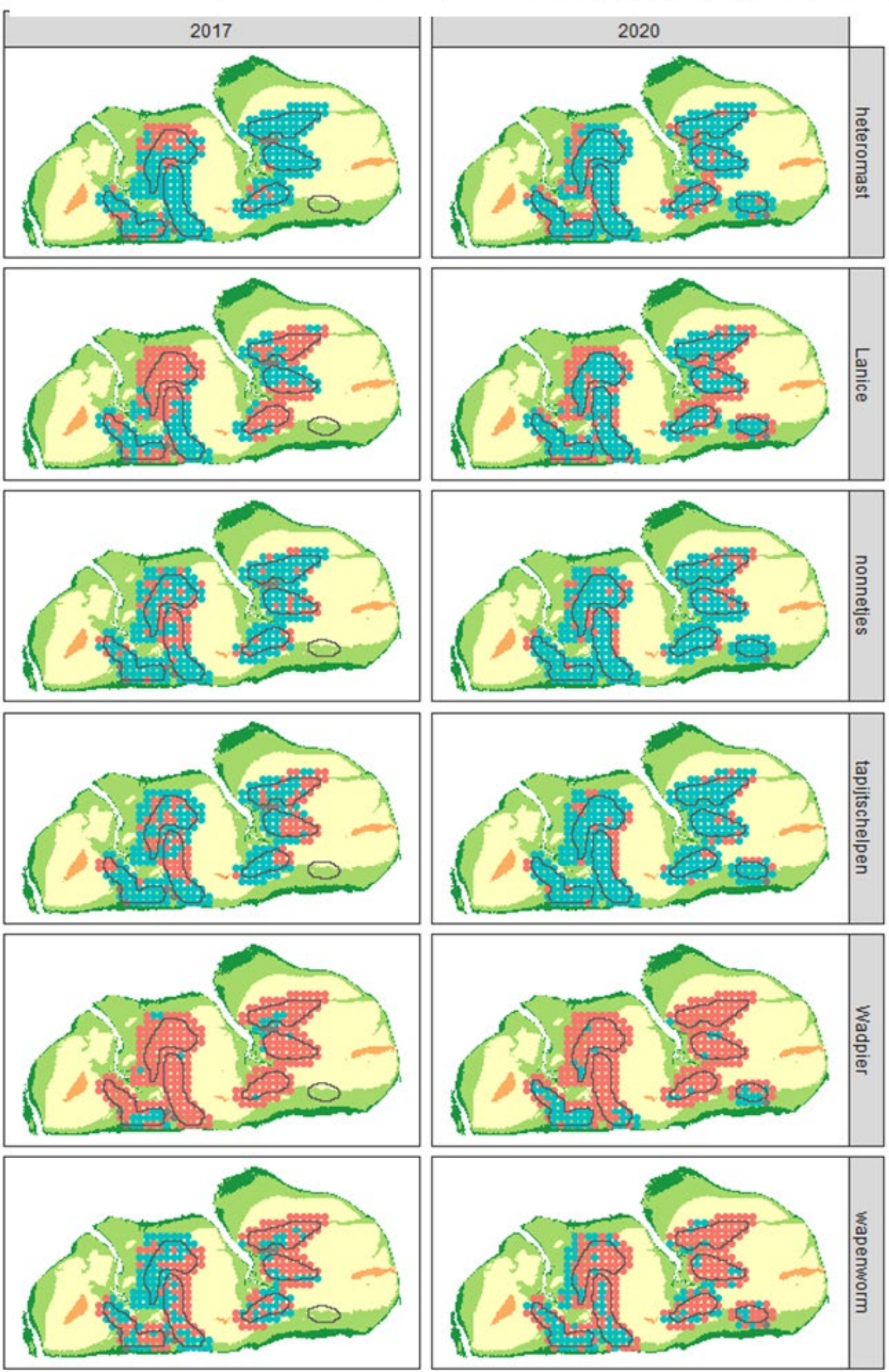

Figuur 6-38 Overzicht van locaties waar verschillende soorten/abiotische kenmerken tijdens de kwalitatieve survey in 2017 en 2020 zijn aangetroffen. Achtergrondkaart: LiDAR RWS 2018 
De diepte van de oxidatielaag (Figuur 6-39) lag voor aanleg rond de 10 en $25 \mathrm{~mm}$. Op de westkant van de Roggenplaat was de oxidatielaag minder diep dan op de oostkant. $\mathrm{Na}$ aanleg is de oxidatielaag in diepte afgenomen. Op enkele locaties vinden we een diepe oxidatielaag $(50 \mathrm{~mm})$. De oxidatielaag, ook wel zuurstofrijke laag, is dus kleiner geworden. Deze afname is mogelijks door afwezigheid van bodemdieren. Bodemdieren zijn afhankelijk van zuurstof voor hun respiratie. Middels diffusie dringt zuurstof slechts de top laag van het sediment in. Bodemdieren kunnen middels hun gangen, bioturbatie en irrigatie zuurstof dieper de bodem in pompen. De oxidatielaag zal in de tijd in diepte toenemen met een toename in bodemdieren.

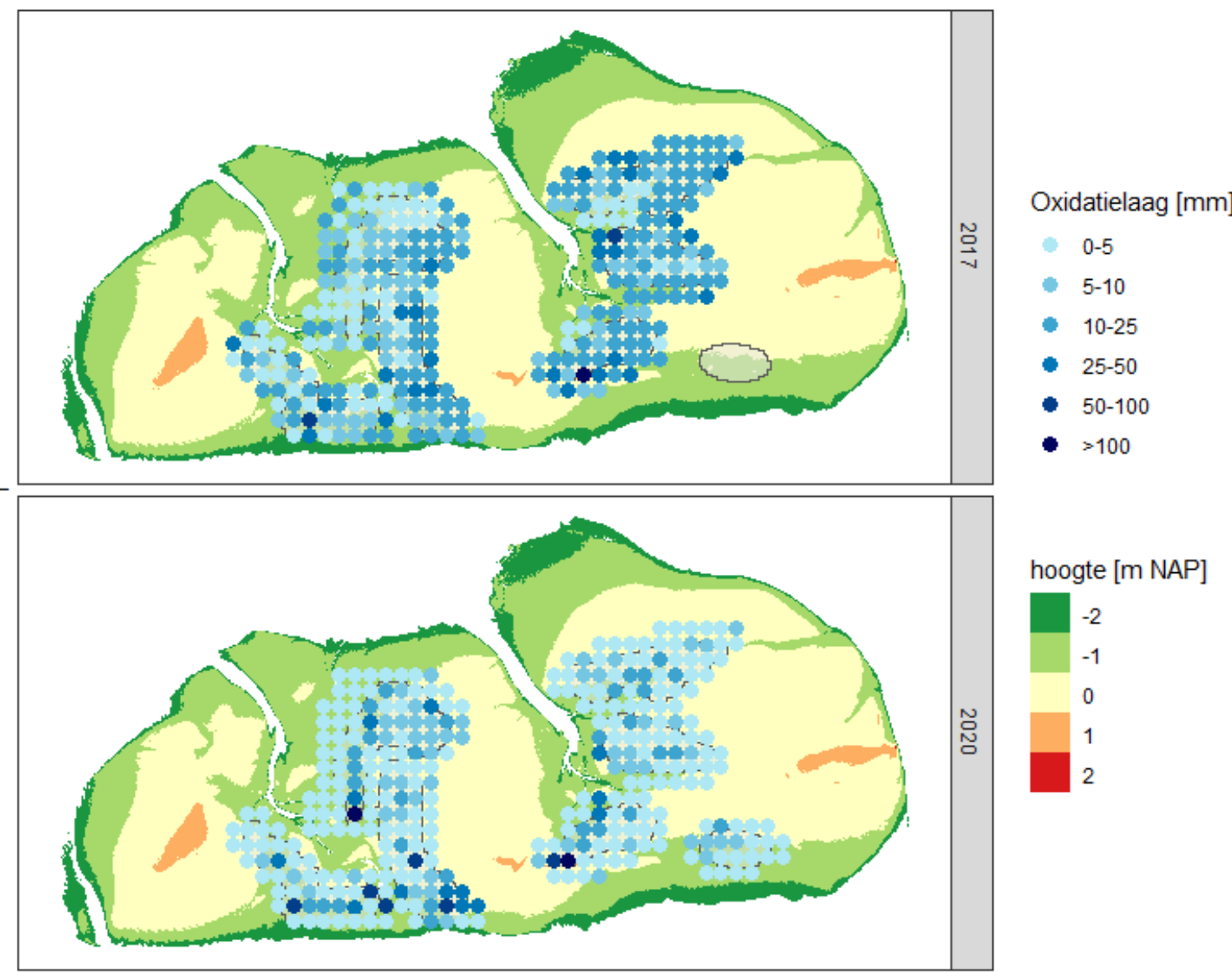

Figuur 6-39 Diepte van de oxidatie laag per monsterlocatie in 2017 en 2020. Achtergrondkaart: LiDAR RWS 2018.

Kleine wadpieren bevonden zich, voor de aanleg van de suppletie, meer op het westelijke deel van de Roggenplaat. Hier kwamen ze vooral in de buurt van suppletie 1 en 5 voor (Figuur 6-40). Middelgrote wadpieren werden verspreid over de hele Roggenplaat waargenomen. Grote wadpieren kwamen vooral veel voor in het gebied waar suppletieelement $2,5,6$, en het zuidelijke deel van suppletie gepland stonden. De verspreiding van grote en kleine wadpieren overlapte nauwelijks met elkaar. De meest opmerkelijke verschillen die te zien zijn na aanleg van de suppletie, is de afwezigheid van grote wadpieren, de toename van kleine wadpieren, en weinig tot geen wadpieren van elk formaat op suppletie 4. Dit lijkt niet geheel in lijn met de observaties tijdens de kwantitatieve bemonstering. Grote wadpieren zijn wel geobserveerd op de suppleties, met name op element 6 en 7. Echter wordt dit verschil waarschijnlijk veroorzaakt door de classificering en zijn de observaties wel in lijn met elkaar. Tijdens de veld-screening wordt onderscheidt gemaakt tussen klein, middel en grote wadpieren, terwijl de kwantitatieve bemonstering alleen onderscheidt maakt tussen klein en groot. Middel grote wadpieren worden waarschijnlijk binnen de kwantitatieve bemonstering gerekend tot grote wadpieren. Kleine wadpieren komen inderdaad vaker voor op de suppletie en suppletie 4 bevat inderdaad weinig tot geen kleine en grote wadpieren. 


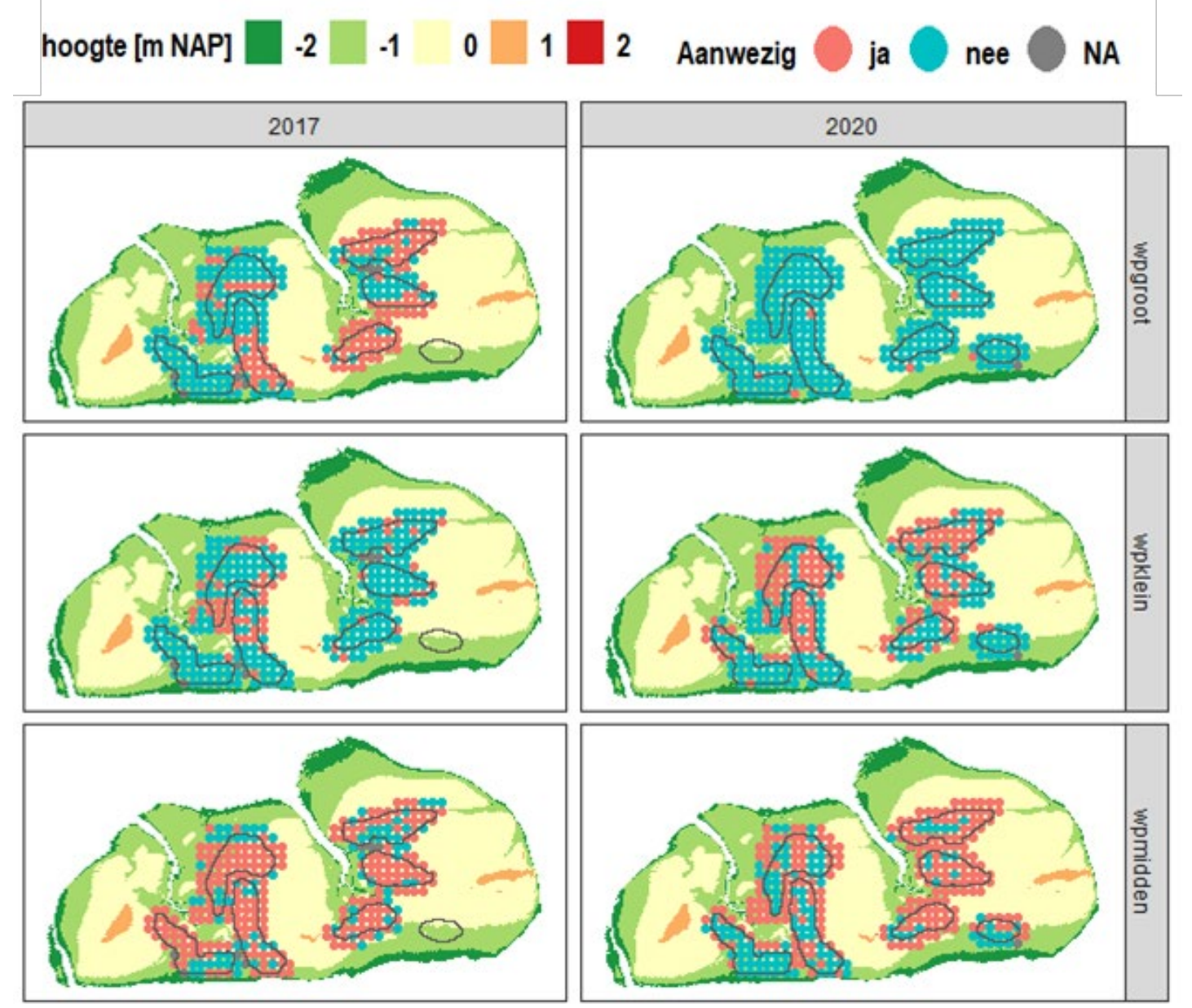

Figuur 6-40 Overzicht van locaties waar verschillende grootte wadpieren (boven groot, midden klein, onder middelmatig) voorkomen tijdens de kwalitatieve survey in 2017 en 2020.

De suppletie-elementen verschillen in dikte en bodemligging na aanleg. De dikte en bodemligging van de suppleties zijn vanzelfsprekend gecorreleerd. Voor nu worden in eerste instantie relaties tussen het bodemleven en de sedimentdikte onderzocht, niet implicerend dat niet ook de bodemligging en verklarende rol kan spelen. Dit wordt in een later stadium onderzocht. We hebben hier de relatie tussen de dikte van de suppletie-elementen en de aanwezigheid/afwezigheid van verschillende soorten onderzocht en in kaart gebracht aan de hand van logistische regressies (Figuur 6-41). De regressielijn (rode stippellijn in Figuur 6-41) geeft de kans weer dat een soort aanof afwezig is bij een bepaalde gesuppleerde dikte. Alleen significante regressielijnen zijn weergegeven. De wapenworm $(p<0.001)$ komt op een brede range aan gesuppleerde diktes voor. Bij een suppletiedikte van een halve meter is de kans dat de wapenworm aangetroffen wordt $\sim 70 \%$. Suppleties dikker dan 1 meter bevatten geen wapenwormen. De zeeduizendpoot, Hediste $(p<0.001)$ treffen we ook aan op een brede range van gesuppleerde diktes. Bij een suppletie-dikte van een halve meter is de kans op afwezigheid groter $(\sim 70 \%)$ dan de kans op aanwezigheid ( $30 \%)$. Kleine wadpieren ( $p$ $=0.04$ ) worden aangetroffen tot een dikte van $\sim 0,75 \mathrm{~m}$, terwijl middelgrote- wadpieren $(p<0.011)$ tot $\sim 0,9 \mathrm{~m}$ worden aangetroffen. Bij een suppletie-dikte van $0,5 \mathrm{~m}$ is de kans dat kleine en middelgrote-wadpieren aangetroffen worden hetzelfde (50\%). Bij dunnere suppleties is de kans groter dat we middelgrote wadpieren aantreffen dan kleine wadpieren. Voor dikkere suppleties is die verhouden andersom. Corophium, Nepthys en Pygospio laten geen significante relatie met gesuppleerde dikte zien. De gemshoornworm wordt een enkele keer op wat dikkere suppletiediktes gezien $(0.5-1$ meter dik). Buldozerkreeftjes ( $p=0.001)$, wadslakjes $(p=0.001)$, zandkokerwormen (Lanice) $(p=0.002)$, nonnetjes $(p=0.003)$ en Heteromastus $(p=0.001)$ laten een 
significant verband zien tussen aan- en afwezigheid en gesuppleerde dikte. Echter neemt bij deze soorten de kans op voorkomen snel af met toenemende suppletiedikte en komen ze nagenoeg alleen tot een halve meter suppletie dikte voor. Bij suppletiediktes van 1 meter en hoger komt 1 jaar na aanleg geen enkele soort voor.
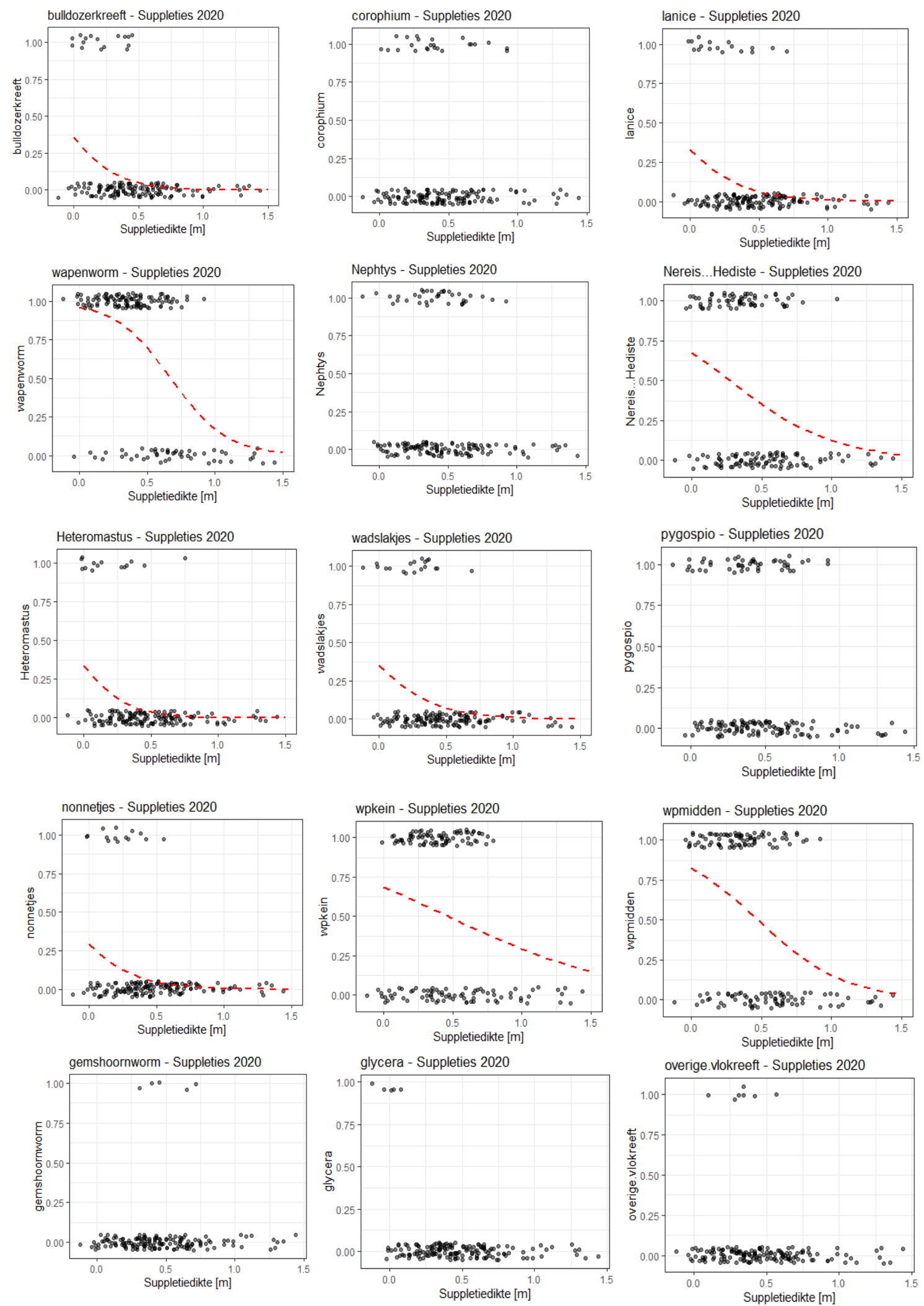

Figuur 6-41 Het wel (1) of niet (0) voorkomen van een soort per suppletie dikte. De rode stippellijnen geven significante logistische regressielijnen weer. Deze lijn geeft de kans dat een soort op de desbetreffende suppletiedikte voorkomt wanneer alleen met deze covariable rekening wordt gehouden. 


\subsubsection{Ontwikkeling bodemdiergemeenschap in relatie tot omgevingsfactoren}

\subsubsection{Methode}

De ontwikkeling van de bodemdiergemeenschap in relatie tot omgevingsfactoren is onderzocht aan de hand van de kwantitatieve benthosbemonstering. Voor de analyse van het bodemdierleven op de suppletie is onderscheid gemaakt tussen dikke $(4,5$ en $7)$ en dunne (1, 2, 3 en 6) suppleties. Verder zijn suppleties 1, 2 en 3 geclassificeerd als noordelijk gelegen suppleties en 4, 5, 6 en 7 als zuidelijk gelegen.

\subsubsection{Resultaten}

Op suppleties met een dikke aangebrachte suppletielaag worden significant lagere totale dichtheiden [ind $/ \mathrm{m}^{2}$ ] geobserveerd in vergelijking tot suppleties met een dunne aangebracht suppletielaag ( $t$-test: $\mathrm{df}=86, p<0.001$ ). Ook leidt de ligging op de Roggenplaat tot significante verschillen in dichtheid $\left[\mathrm{ind} / \mathrm{m}^{2}\right]$ tussen noordelijke en zuidelijke gelegen suppleties ( $t$-test: $\mathrm{df}=86, p=0.03$ ). Zuidelijke suppleties liggen op een dynamischere plek en worden meer blootgesteld aan golfwerking dan noordelijke suppleties. Of verschillen worden veroorzaakt door de ligging van de suppletie of de dikte van de aangebrachte suppletielaag is niet te onderscheiden, aangezien in het noorden van de Roggenplaat alleen dunne suppleties voorkomen (Figuur 6-42). We vermoeden echter dat het effect op soortenrijkdom en soortendichtheid wordt veroorzaakt door de dikte van de suppletieaag en niet de ligging gezien suppletie 6 , een dunne suppletie in het zuiden, de hoogste dichtheid en soortenrijkdom bevat.

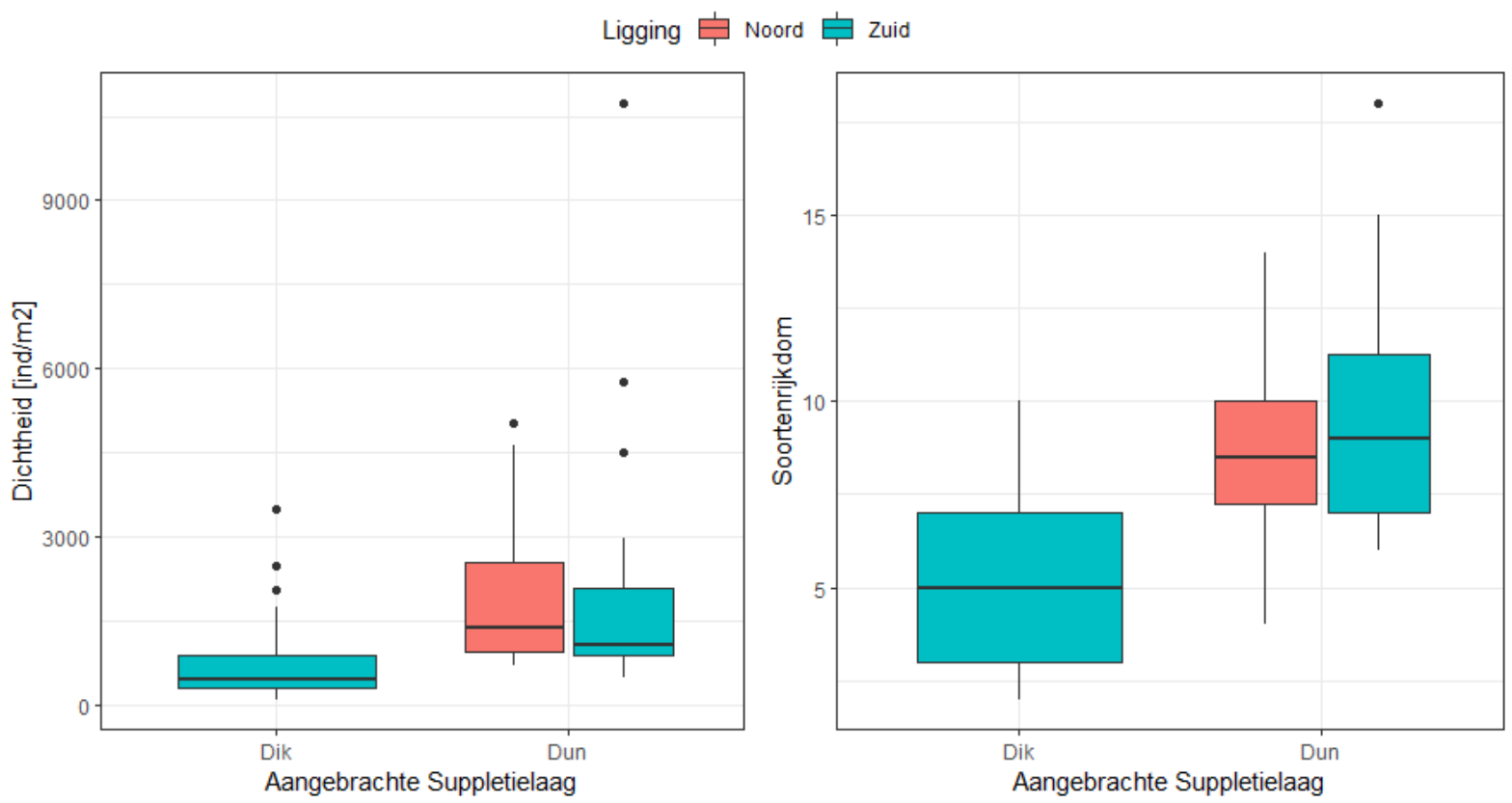

Figuur 6-42 Verdeling van totale dichtheid voor dikke (suppletie 4, 5 en 7) en dunne (suppletie 1, 2, 3 en 6) suppleties gelegen aan de noord- en zuidzijde van de Roggenplaat.

De bemonstering op de suppletie is uitgevoerd volgens een stratified random design. Voor dunne suppleties is geen duidelijk patroon te zien tussen locaties gelegen op de top van de suppletie, aan de geëxponeerde zijde en aan de luwe zijde (Figuur 6-43). Voor de dikke suppleties zien we hogere dichtheden en soortenrijkdom op de beschutte locaties. Doordat suppletie 6 , een dunne suppletie in het zuiden, geen verschil toont tussen de suppletie zones, vermoeden wij dat de dikte van de suppletie de 
doorslaggevende rol speelt in deze relatie. In de toekomst moet nog uitwijzen welke factor een belangrijkere rol speelt en of het specifiek de dikte is die verklarend is of dat de hieraan gerelateerde bodemligging (en dus droogvalduur) sturend is.

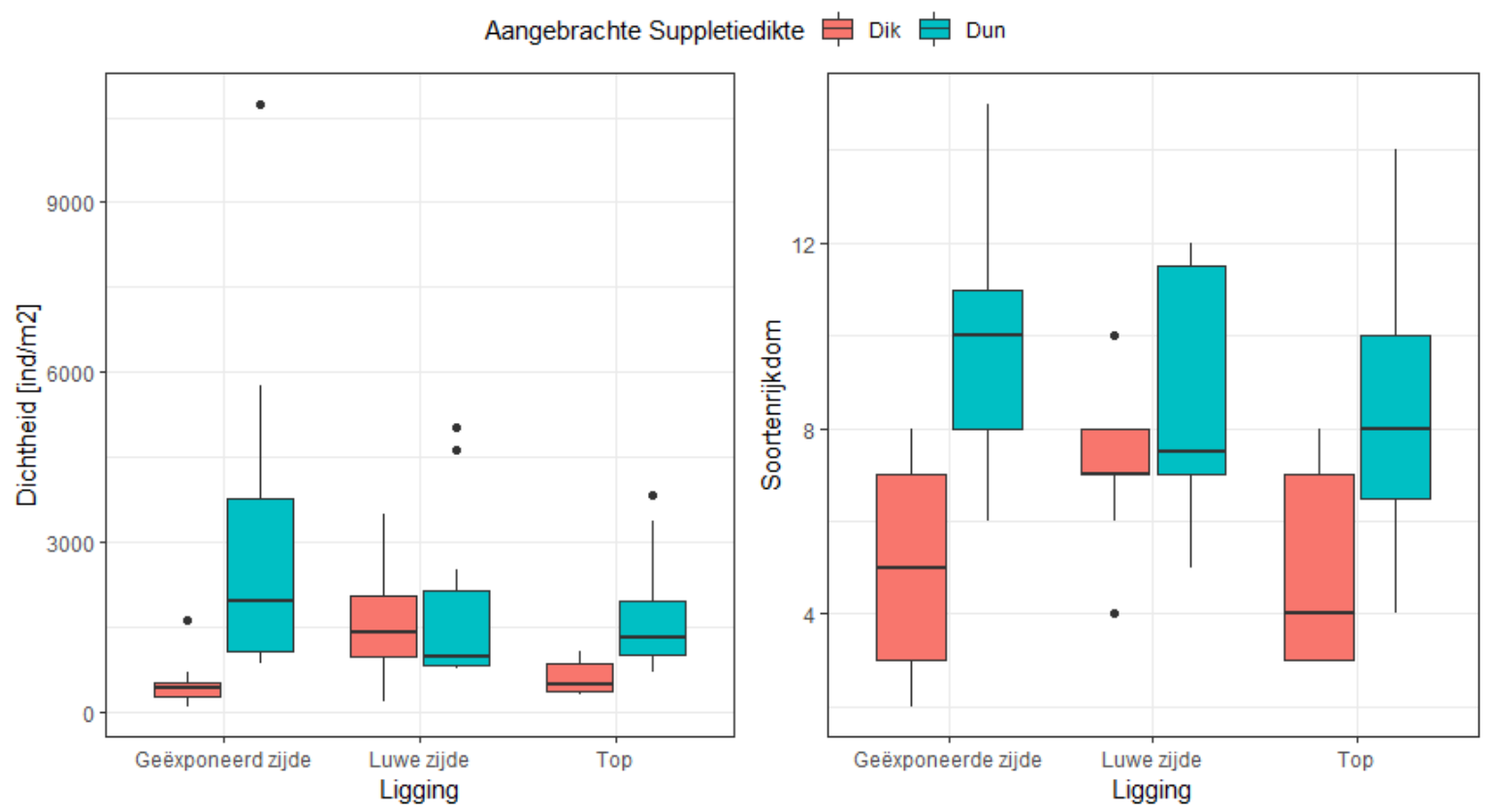

Figuur 6-43 Gemiddelde dichtheid voor beschutte en blootgestelde plekken en de top van de suppletie in 2020.

De totale dichtheid neemt exponentieel af met toenemende suppletiediktes, terwijl soortenrijkdom lineair af lijkt te nemen (Figuur 6-44). Boven een suppletiedikte van $\sim 0.75 \mathrm{~m}$ wordt een zeer lage totale dichtheid geobserveerd. Suppletie 4 laat twee uitschieters zien van opvallend hoge dichtheden bij een suppletie dikte van meer dan 1 meter. Deze worden voornamelijk veroorzaakt door de, in relatief hoge dichtheden, aanwezige Bathyporeia pilosa. Doordat de data een exponentieel verloop vertoont is voor het fitten van een regressie-model een log-transformatie uitgevoerd. Hierbij heeft de dikte van de suppletielaag een significant effect op de totale dichtheid van benthos [ind. $\cdot \mathrm{m}^{-2}$ ], waarbij de dichtheid afneemt met toenemende suppletie dikte $(p<0.001$, df $=86)$. De geobserveerde dichtheden worden voor $39 \%$ verklaard door de suppletiedikte $\left(R^{2}=0.387\right)$. Ook heeft de dikte van de suppletielaag een significant effect op soortenrijkdom $(p<0.001, \mathrm{df}=86)$, en verklaart $43 \%$ van de variatie $\left(\mathrm{R}^{2}=0.426\right)$.
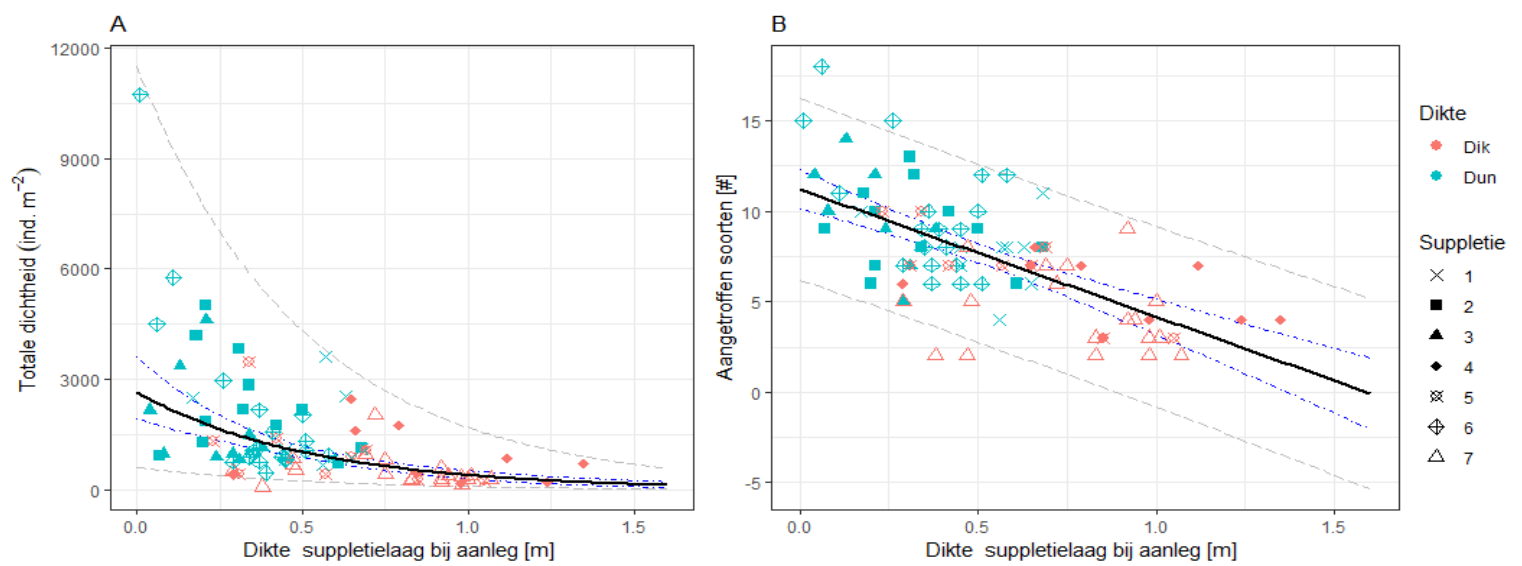

Figuur 6-44 Relatie tussen de suppletie dikte bij aanleg en totale dichtheid in ind. $\mathrm{m}^{-2}\left(A: \mathrm{R}^{2}=\right.$ 0.387 ) en soortenrijkdom ( $\left.B: R^{2}=0.426\right)$. Blauw gestreepte lijnen geven het $95 \%$ betrouwbaarheidsinterval van de regressie. De grijs gestreepte lijnen geven het $95 \%$ voorspelde interval weer. 
Het percentage zeer fijn zand heeft een significant effect op zowel de totale dichtheid ( $p$ $<0.001, \mathrm{df}=86)$ als de soortenrijkdom $(p<0.001, \mathrm{df}=86$ ) (Figuur 6-45). Zeer fijn zand verklaart $24 \%$ van de variatie in totale dichtheid en $43 \%$ van de variatie in soortenrijkdom. Uit de gemiddelde sedimentsamenstelling van de suppleties is af te leiden dat voor de aanleg van de suppletie middel fijn tot grof sediment gebruikt is waar weinig tot geen slib en zeer fijn zand in aanwezig was (Figuur 6-20). Voornamelijk op locaties gelegen op dunne suppleties, met een kleine suppletie dikte, is fijn zand aanwezig (Figuur 6-46). Wij vermoeden dat het bodemleven hier in staat is geweest de bodem zodanig om te woelen dat het gebiedseigen sediment naar boven is gebracht.
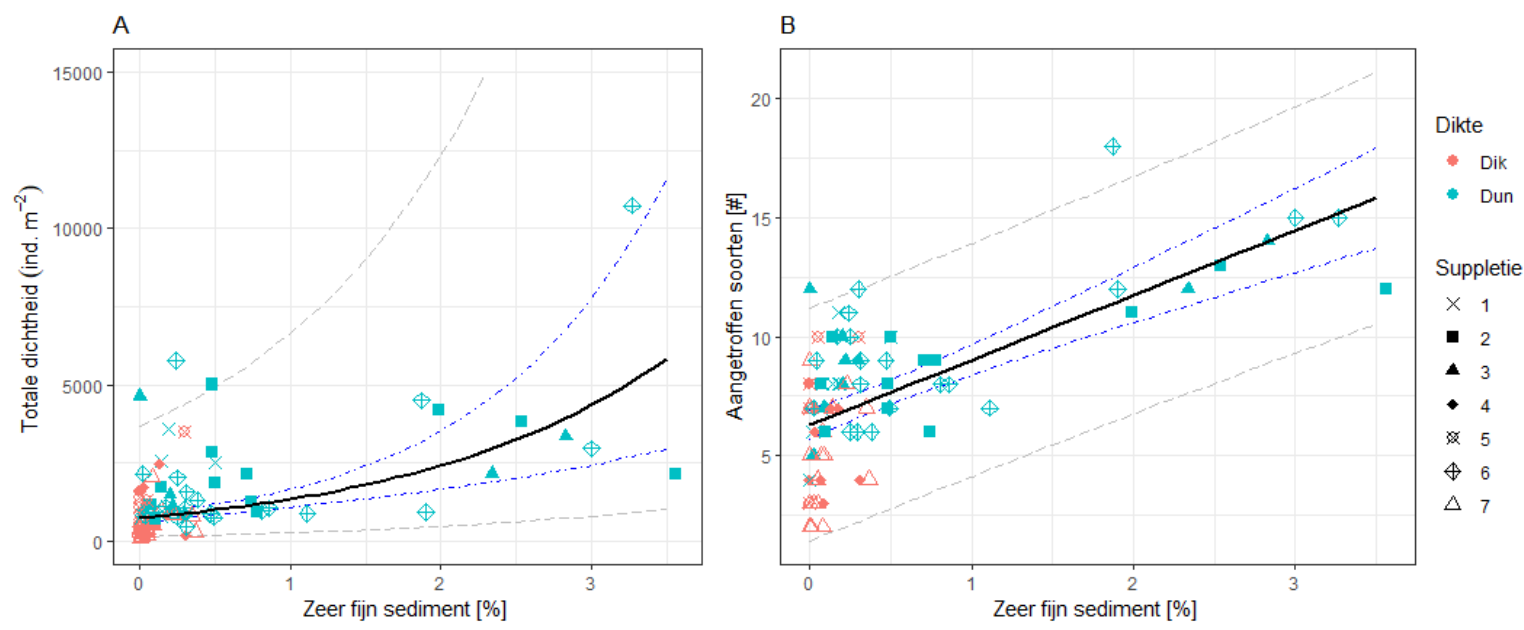

Figuur 6-45 Relatie tussen het percentage zeer fijn zand en de totale dichtheid $\left(A: R^{2}=0.244\right)$ en soortenrijkdom $\left(B\right.$ : $\left.R^{2}=0.430\right)$. Blauw gestreepte lijnen geven het $95 \%$ betrouwbaarheidsinterval. De grijs gestreepte lijnen geven de $95 \%$ voorspelde interval weer.

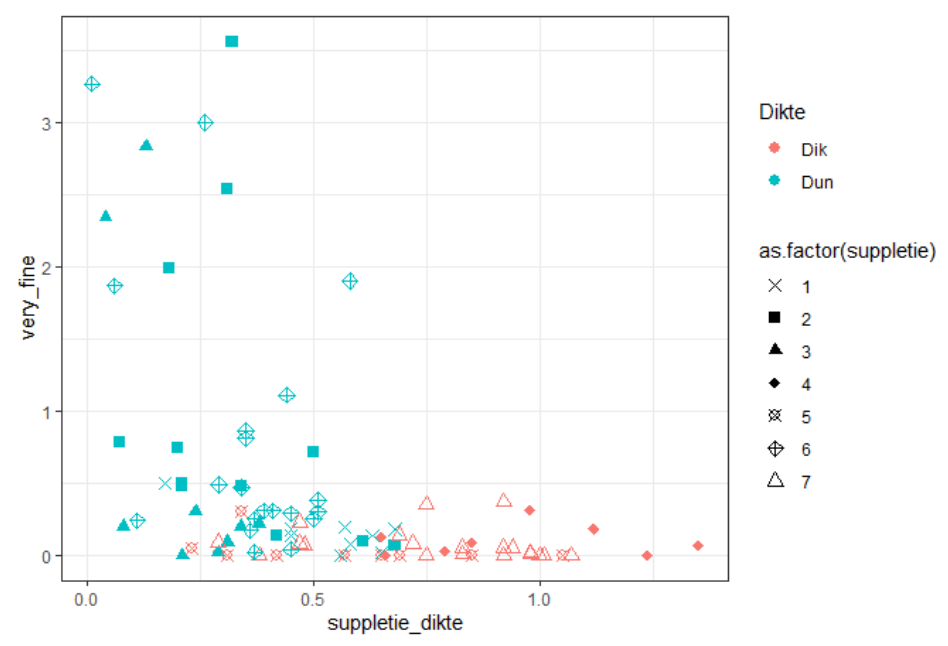

Figuur 6-46 Relatie tussen suppletiedikte en het percentage zeer fijn zand.

\subsubsection{Priming}

\subsubsection{Methode}

Er zijn door Boskalis drie vakken met een schaal van $50 \times 100 \mathrm{~m}$ 'geprimed' met gebiedseigen sediment, incl bodemleven, op het noordoostelijk gelegen suppletieelement (suppletie-element 2). Tevens is door Boskalis een priming middels het uitstrooien van kokkels uitgevoerd binnen twee vakken met een schaal van $50 \times 100 \mathrm{~m}$, 
zie paragraaf 0 . Het bodemleven is vervolgens bemonsterd een week (18 november 2019), 4 maanden (31 maart 2020), 7 maanden (22 juni 2020) en een jaar ( 4 november 2020) na aanleg van het laatste primevak. Per primevak, geprimed met gebiedseigen sediment, zijn op 5 locaties (in totaal 15 locaties) bodemdieren bemonsterd (Figuur 6-47, zwarte polygonen). Daarnaast zijn 5 locaties bemonsterd in 3 referentiegebieden (in totaal 15 locaties) gelegen 100 meter ten noorden van de geplande suppletie (Figuur 6-47, groene polygonen). Op elke locatie zijn telkens 3 steekbuizen van $10 \mathrm{~cm}$ genomen. De steekbuizen zijn binnen een straal van 1 meter rondom het gedefinieerde monsterpunt circa $35 \mathrm{~cm}$ in het sediment gestoken. De inhoud van de steekbuizen is daarna samengevoegd en over een $1 \mathrm{~mm}$ zeef gezeefd. Het residu is in een monsterpot gedaan en op het lab geconserveerd door het toevoegen van geneutraliseerde formaline tot een uiteindelijke concentratie van $4 \%$. Om de dieren beter zichtbaar te maken zijn de monsters voor analyse in het lab gekleurd met Bengaals roze. Daarna zijn ze gesorteerd en onder een microscoop op naam gebracht en per soort gewogen. Voor het wegen is het aanhangende water zoveel mogelijk met filtreerpapier verwijderd. Totale biomassa per locatie is nog niet beschikbaar ten tijde van deze rapportage. Dichtheden van Arenicola zijn in het veld bepaald door de hoopjes te tellen in een frame van $50 \times 50$ $\mathrm{cm}(\mathrm{n}=10$ per locatie).

De met kokkels ingezaaide vakken zijn gelijktijdig met de andere primingvakken bemonsterd. Alleen één jaar na aanleg (november 2020) heeft er geen bemonstering plaatsgevonden binnen de met kokkels geprimde vakken (kokkelvak). Per kokkelvak zijn op 8 locaties (in totaal 16 locaties) alle kokkels en tapijtschelpen verzameld binnen een kwadrant van $50 \times 50 \mathrm{~cm}$. Vervolgens zijn in het lab voor elke individu lengtes en natgewicht bepaald. Per monsterlocatie is het asvrijdrooggewicht bepaald van 3 kokkels. Hiervoor werd het vlees van de schelp gescheiden. Vervolgens werd het kokkelvlees gedroogd bij $70^{\circ} \mathrm{C}$ tot een constant gewicht alvorens ze te verassen bij $540^{\circ} \mathrm{C}$ tot een constant gewicht. Asvrijdrooggewichten voor de overige kokkels zijn berekend met regressies van asvrijdrooggewicht op zowel lengte als natgewicht.

Voor het opvolgen van morfologische effecten van de priming zijn tevens op elke locatie 1 sediment core, $3 \mathrm{~cm}$ diep, genomen t.b.v. bepaling korrelgrootteverdeling en 3 chlorofyl-a cores, $1 \mathrm{~cm}$ diep, die zijn samengevoegd voor chlorofyl-a bepaling. De chlorofyldata zijn nog niet beschikbaar. 


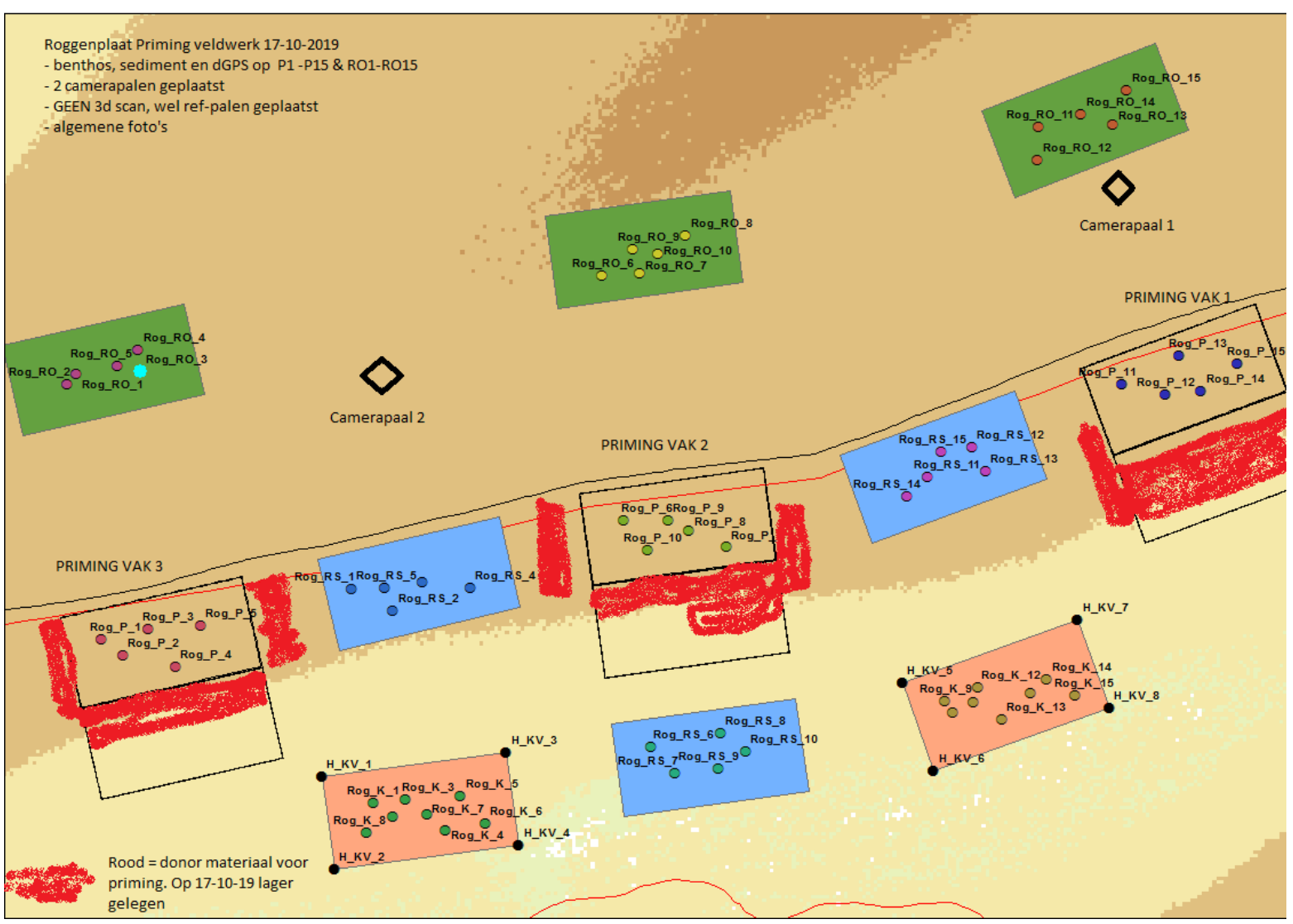

Figuur 6-47. Overzicht bemonstering priming suppletie element 2. Zwartomlijnde vakken geven priming vak 1,2 en 3 weer met per vak 5 monsterlocaties. Groene en blauwe vakken zijn referentievakken buiten de suppletie (groen) en op de suppletie (blauw) met in elk vak 5 monsterlocaties. In de roze vakken zijn kokkels aangebracht op het gesuppleerde sediment afkomstig uit de winplaats. Hier bevinden zich 8 monsterlocaties per vak. De rode gebieden geven aan waar het materiaal voor de priming met gebiedseigen materiaal afkomstig van was.

Voor het meten van morfologische effecten van priming zijn de geprimede locaties ingemeten met de 3D-laserscanner om daarmee regelmatig vlakdekkende hoogteveranderingen te meten. Op luchtfoto's is te zien dat de geprimede locaties lager zijn komen te liggen dan het gesuppleerde deel van element 2 (Figuur 6-48). Hierdoor blijft er water staan op de geprimede locaties. De 3D-scan kan niet door water meten en kan met veel water niet uitgevoerd worden. De 3D-scan focust zich op de geprimede locaties, maar beperkt zich niet tot deze locaties. Ook delen van de suppletie en de kokkelpriming worden tijdens het scannen van de geprimede locaties meegescand. De 3D-scan is uitgevoerd in november 2019, april en juni 2020. Tijdens de bemonstering in november werkte de 3D-scanner niet goed waardoor de meting niet uitgevoerd kon worden. Naar verwachting is alleen de laatste 3D-scan goed gelukt i.v.m. een goede kalibratie na een onderhoudsbeurt. 


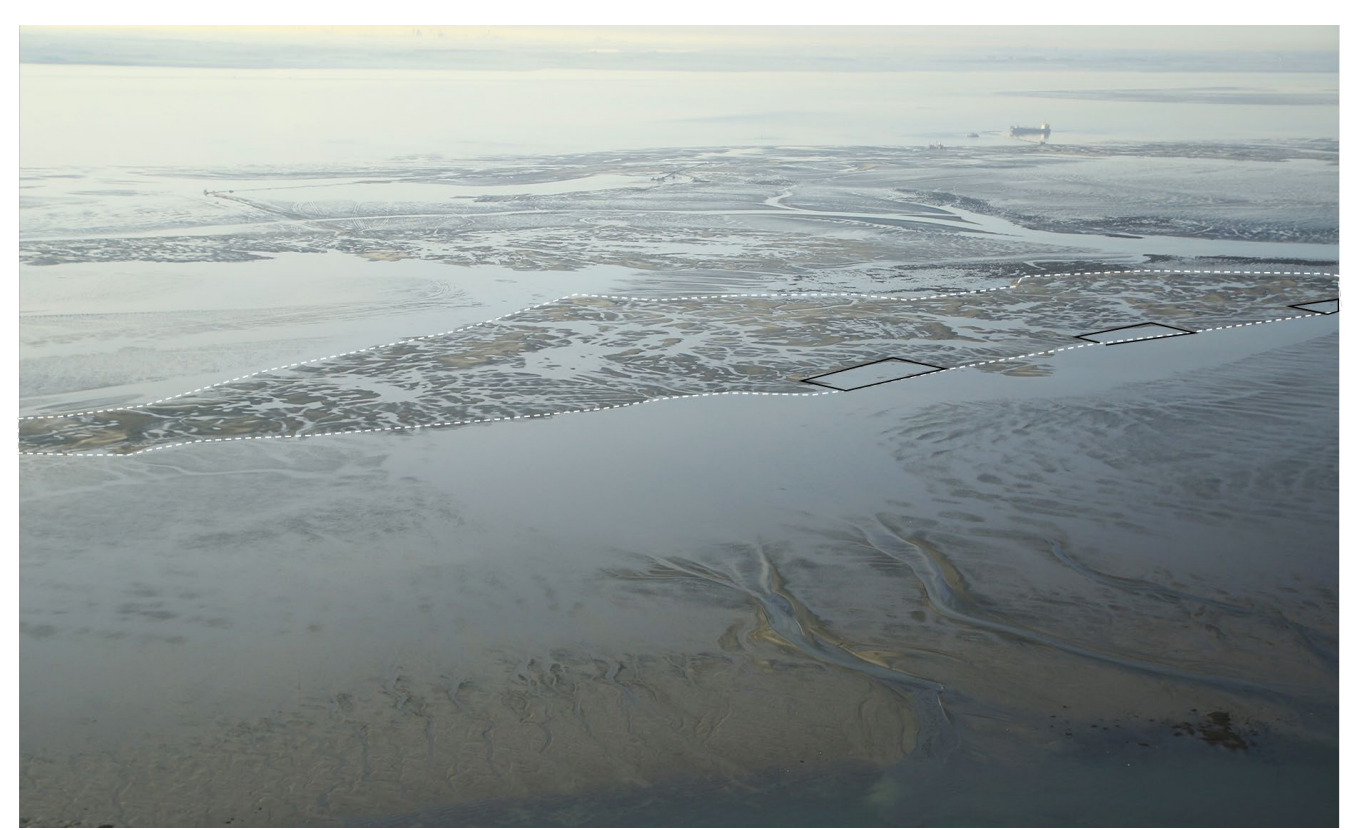

Figuur 6-48 Suppletie element 2 vanuit het Noordoosten. De priming vakken (zwarte ingetekende polygonen) liggen na aanleg van de suppletie (witte stippellijn) lager waardoor hier water blijft staan.

\subsubsection{Resultaten sediment samenstelling priming}

Met de hoogteverdeling van de plots op en rond suppletie 2 wordt aangetoond (overeenkomstig met de in paragraaf 6.2 .3 besproken SED observaties), dat de suppletie en de referentie gebieden vrij stabiel in hoogte zijn (Figuur 6-50). Alleen de geprimede plots (grijs) laten sedimentatie zien. Dit komt waarschijnlijk door de manier van aanleg: de priming-plots zijn eerst aangebracht op een hoogte van ca $+15 \mathrm{~cm}$ NAP, waarna de omliggende suppletie is opgespoten tot een hoogte van circa $+30 \mathrm{~cm}$ NAP (d.w.z., dus 15 centimeter hoger dan de priming plots). Hierdoor kan er sediment vanuit de omgeving versneld naar de priming 'putten' zijn gevloeid, waardoor deze versneld ophogen met omliggend sediment van de suppletie. Bij dit proces is het stagnante water dat eerst op de priming plots stond (zie Figuur 6-48) veelal verdwenen.

Zowel de korrelgrootte (als de bulkdichtheid) tonen tussen de behandelingen en door de tijd weinig variatie (Figuur 6-51).

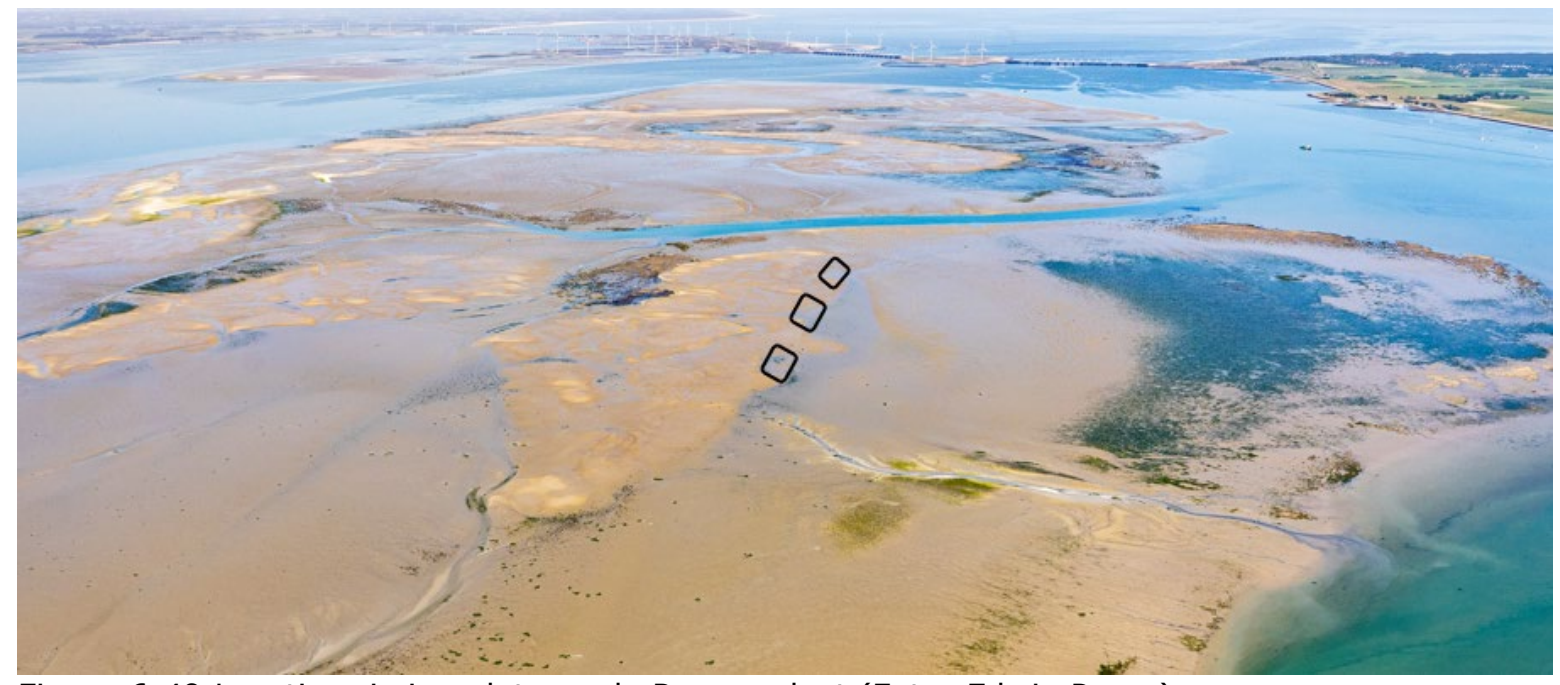

Figuur 6-49 Locatie priming plots op de Roggenplaat (Foto: Edwin Paree). 


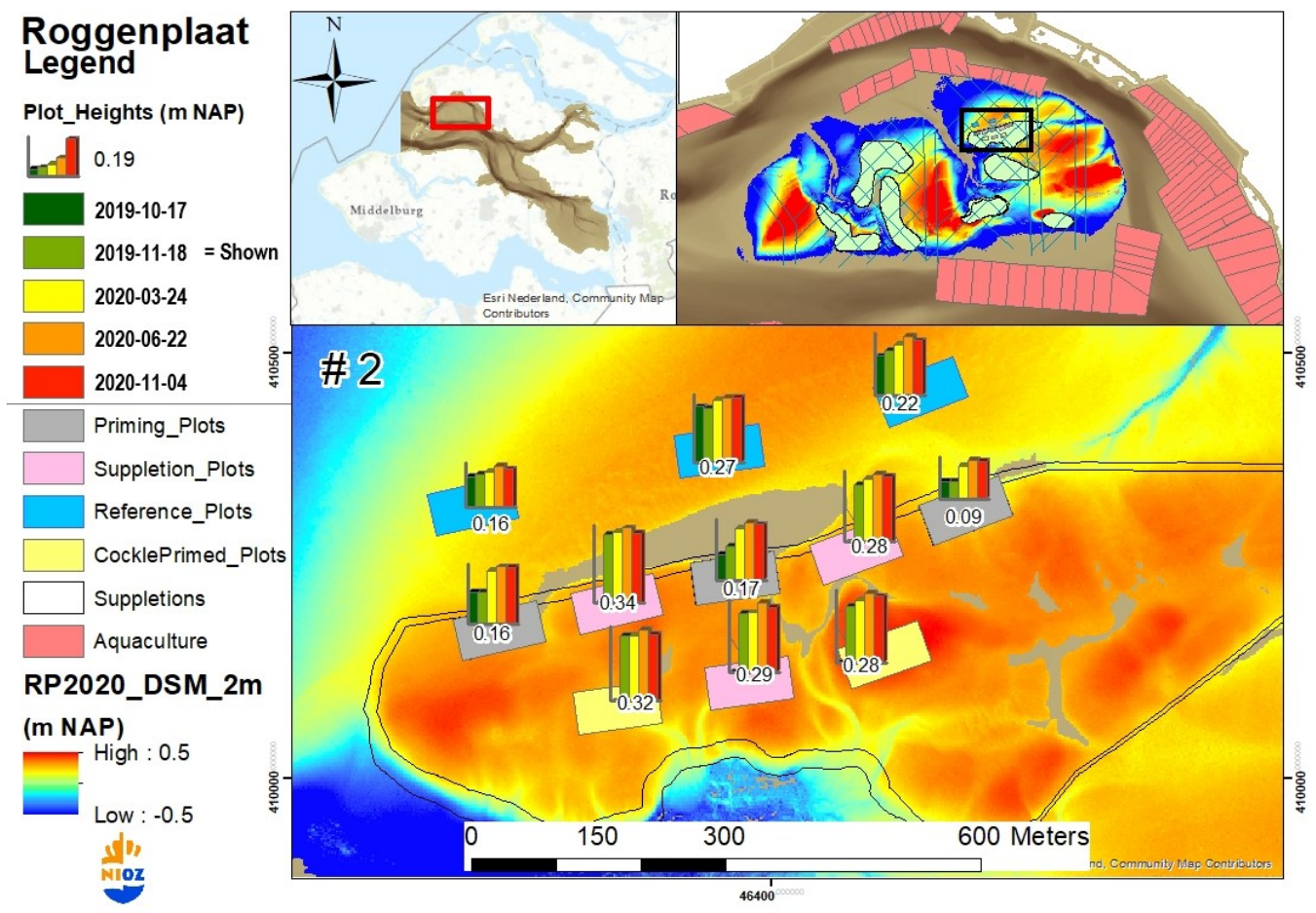

Figuur 6-50. Gemiddelde hoogteverdeling $(n=5)$ van aangebrachte plots op suppletie 2 van de Roggenplaat. Het aangegeven nummer is de hoogte in m NAP van 18 november 2019 (lichtgroene balk).

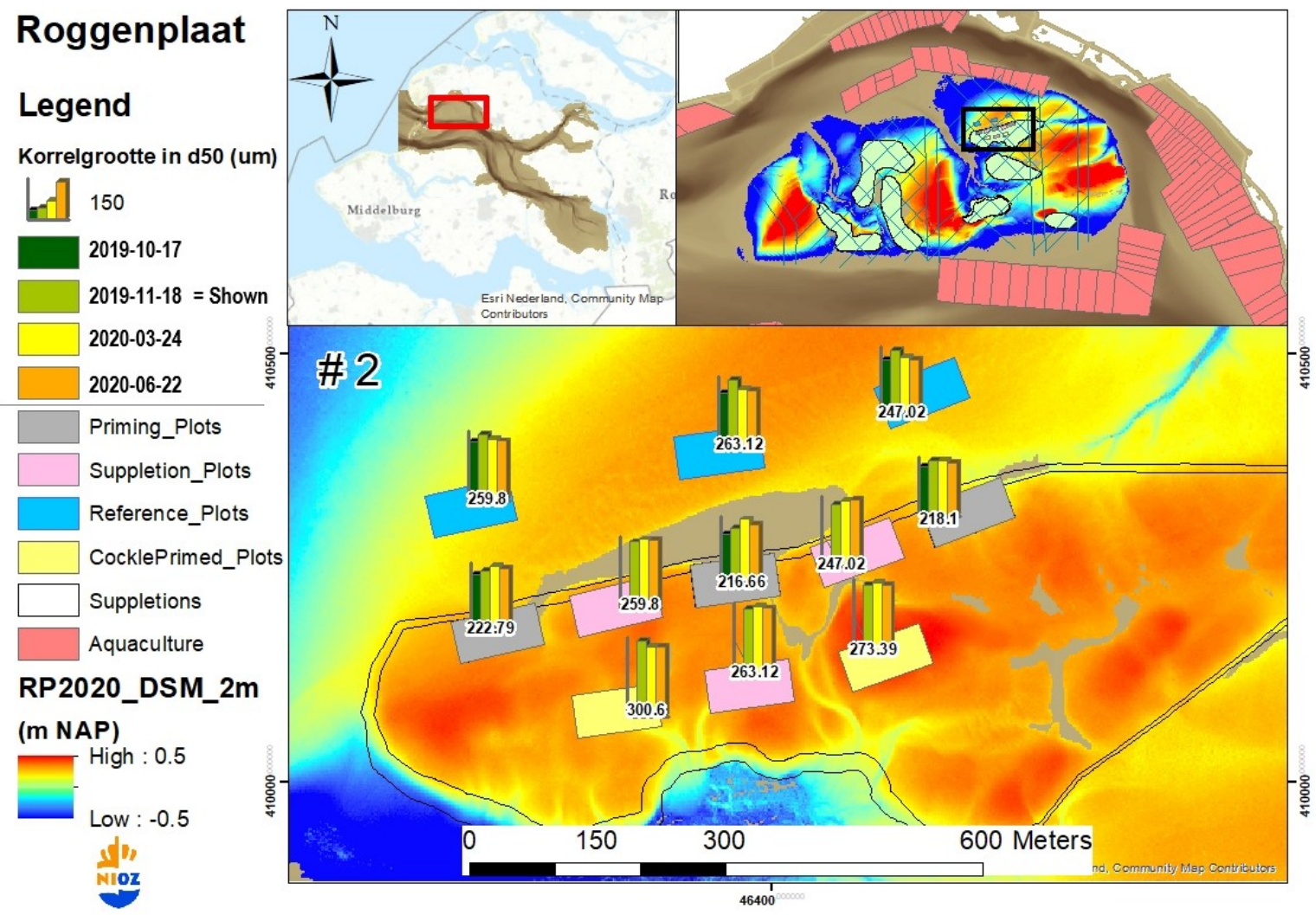

Figuur 6-51. Korrelgrootte uitgedrukt in d50 ( $4 \mathrm{~m})$ van aangebrachte plots op suppletie 2 van de Roggenplaat. Het aangegeven nummer is de gemiddelde meting $(n=5)$ van 18 november 2019 (licht groene kleur) 


\subsubsection{Resultaten: Benthos-priming}

Zoals al eerder aangegeven moet er door het Covid virus nog een groot deel van de benthos-monsters uitgezocht worden. Hieronder worden een beperkt aantal preliminairy resultaten weergegeven. Van iedere vorm van plots zijn nu nog slechts 4 monsters per datum uitgezocht (Benthosbemonstering met steekbuis op de met kokkel geprimede plots is in 2020-06 gestart). Hieronder worden de gemiddeldes van vier dominante soorten (Hediste diversicolor, Limecola balthica, Peringia ulvae, Urothoe poseidonis) die $\pm 20 \%$ van het totale monsters representateren, met gevolg is er nog geen statistiek op uitgevoerd, weergegeven.

Vrijwel alle vier de soort laten dezelfde trend zien (Figuur 6-52, Figuur 6-53, Figuur 6-54 en Figuur 6-55). Het onverstoorde gebied (= referentie) heeft een stabiele benthos samenstelling. Door in de priming behandeling te suppleren met de originele omliggende toplaag krijgt het bodemleven een kick-start in vergelijking met de suppletie van 'kaal/dood' zand (suppletie). Het lijkt erop of de priming met omliggend sediment (Grijs) een beter effect heeft dan de priming met alleen kokkel individuen (Geel).

Zodra alle monsters geanalyseerd zijn kunnen voor alle bodemdieren een ruimtelijke weergave in de tijd gemaakt worden, hieruit zal een beter beeld gecreëerd worden van de uitwerking van de priming. Daarnaast zal gecontroleerd worden of de methode van uitgraven van $0.25 \mathrm{~m} 2$ voor kokkels dezelfde waardes geeft als de steekbuis-methode (deze lijkt in de voorlopige analyse kokkels onder te representeren).

De zeeduizendpoot $(H$. diversicolor) en de wadpieren, die handmatige geteld zijn in het veld, laten beide een exponentiele toename in aantallen zien in juni 2020 (Figuur 6-52 en Figuur 6-56). Voor beide soorten geldt dat er in deze periode significant meer individuen aanwezig zijn in de suppletie en geprimed_vakkken (gebiedseigen sediment en met kokkels ingezaaide vakken) dan in de referentie.

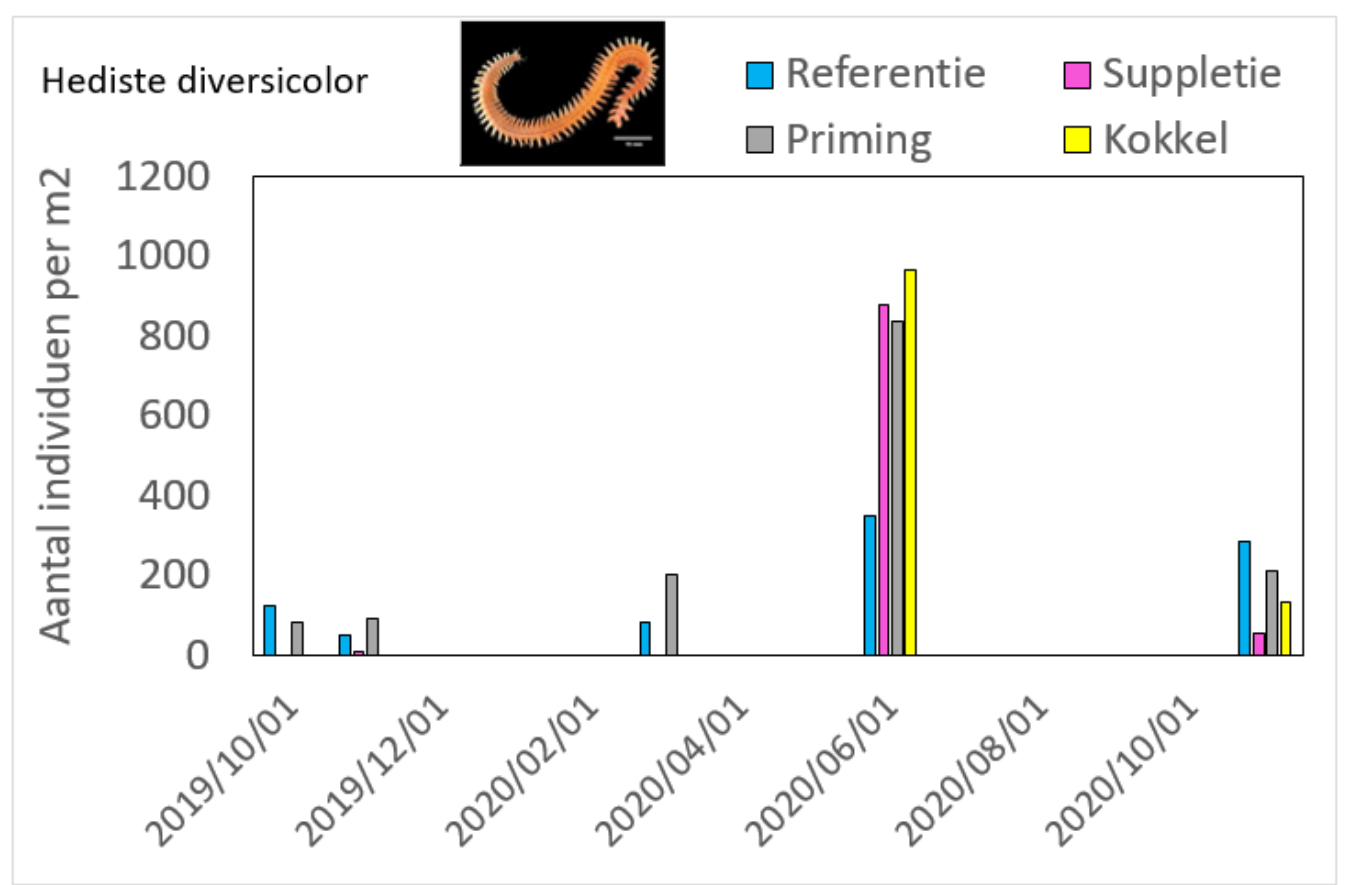

Figuur 6-52 Aantal Hediste diversicolor binnen vier verschillende primingvakken op en rond suppletie 2 van de Roggenplaat. 


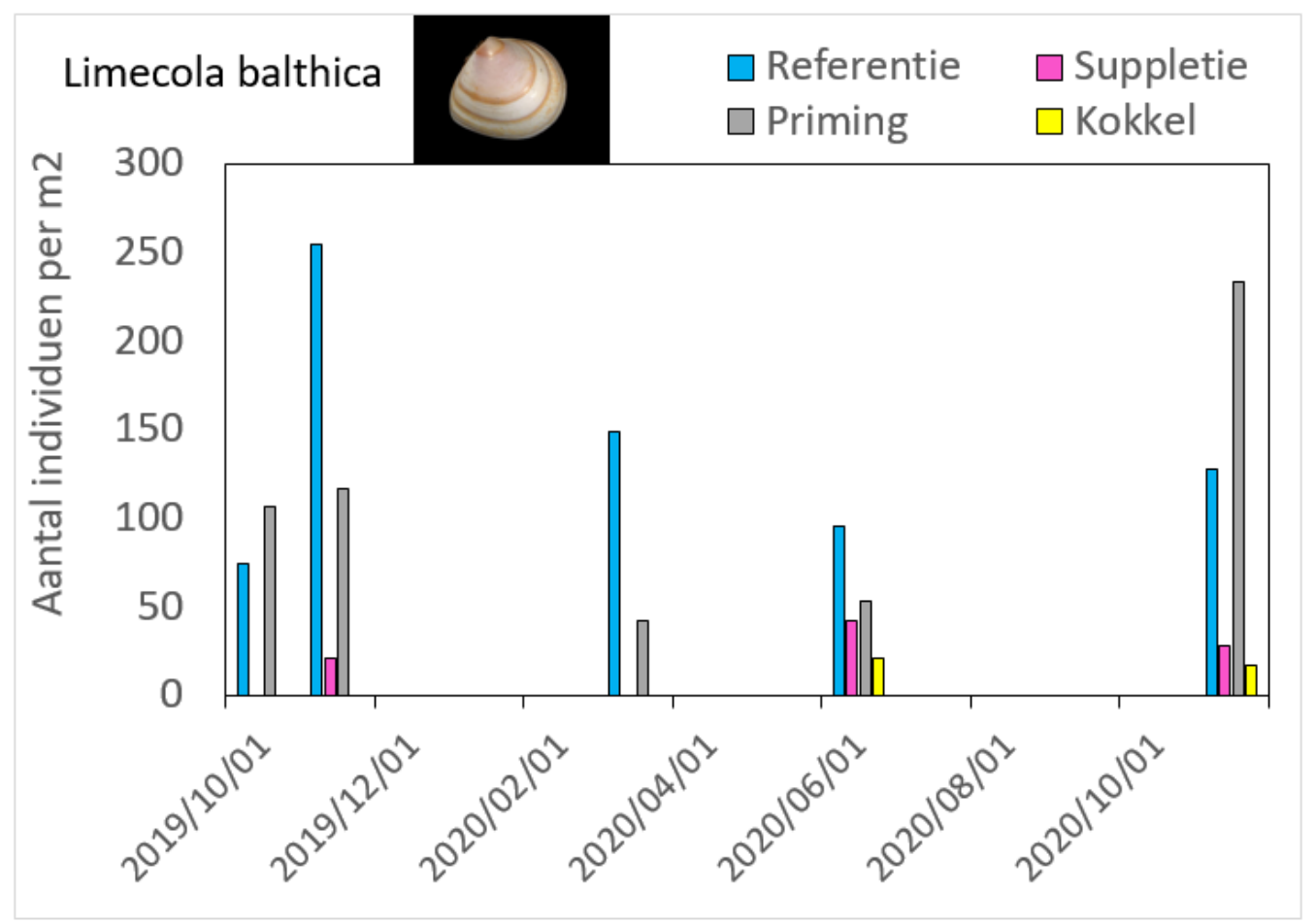

Figuur 6-53. Aantal Limecola balthica binnen vier verschillende primingvakken op en rond suppletie 2 van de Roggenplaat.

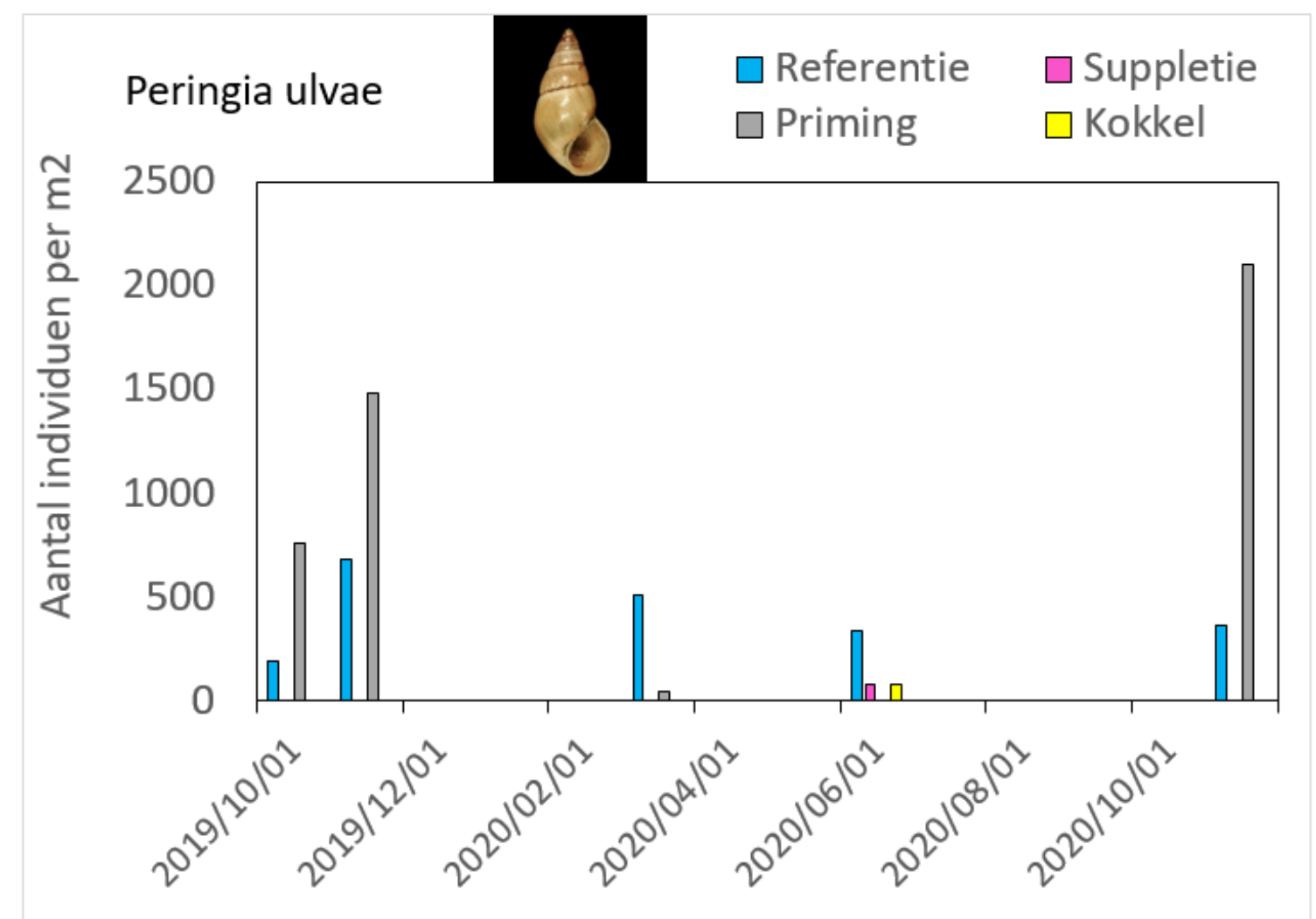

Figuur 6-54. Aantal Peringia ulvae binnen vier verschillende primingvakken op en rond suppletie 2 van de Roggenplaat. 


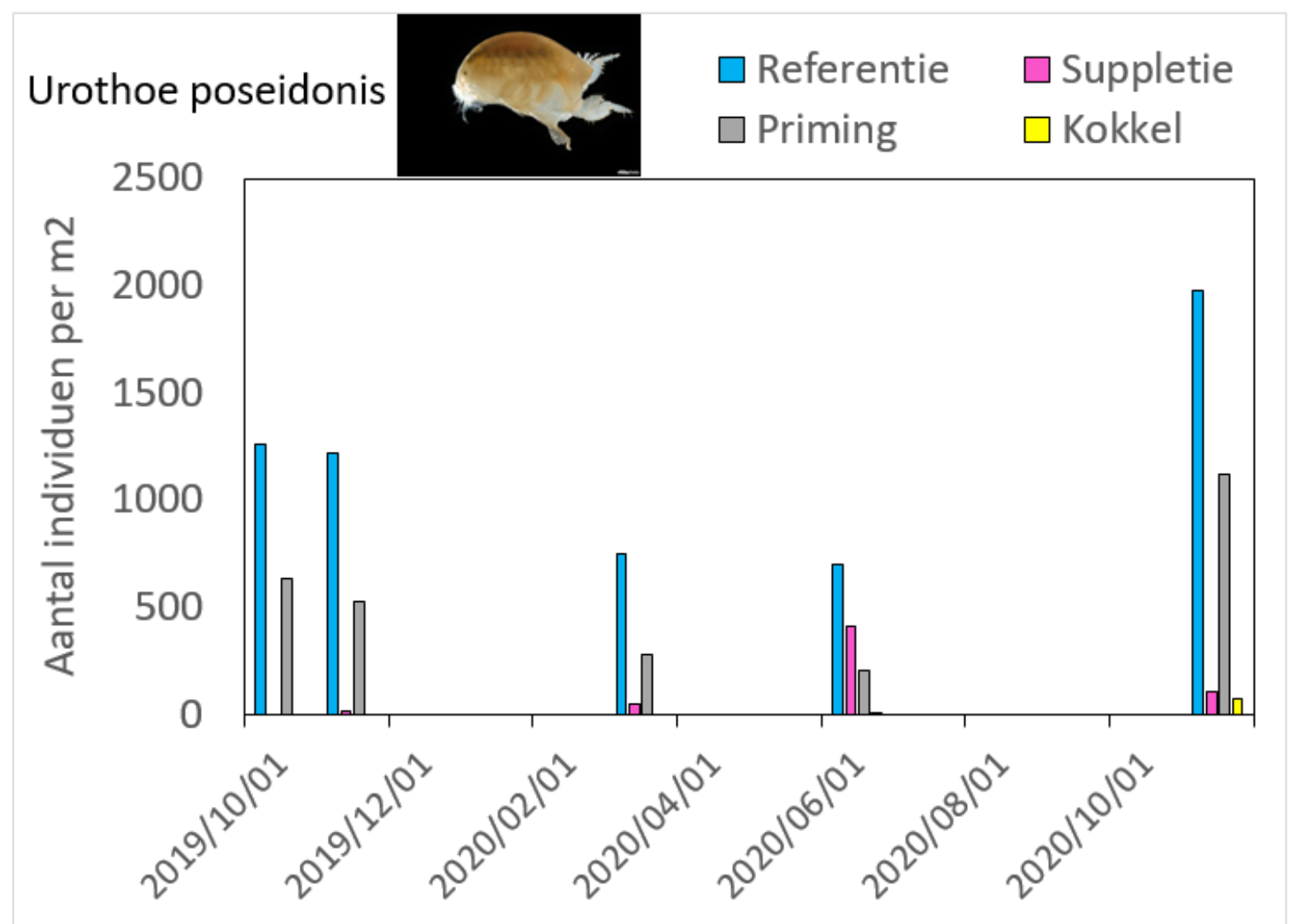

Figuur 6-55. Aantal Urothoe poseidonis binnen vier verschillende primingvakken op en rond suppletie 2 van de Roggenplaat.

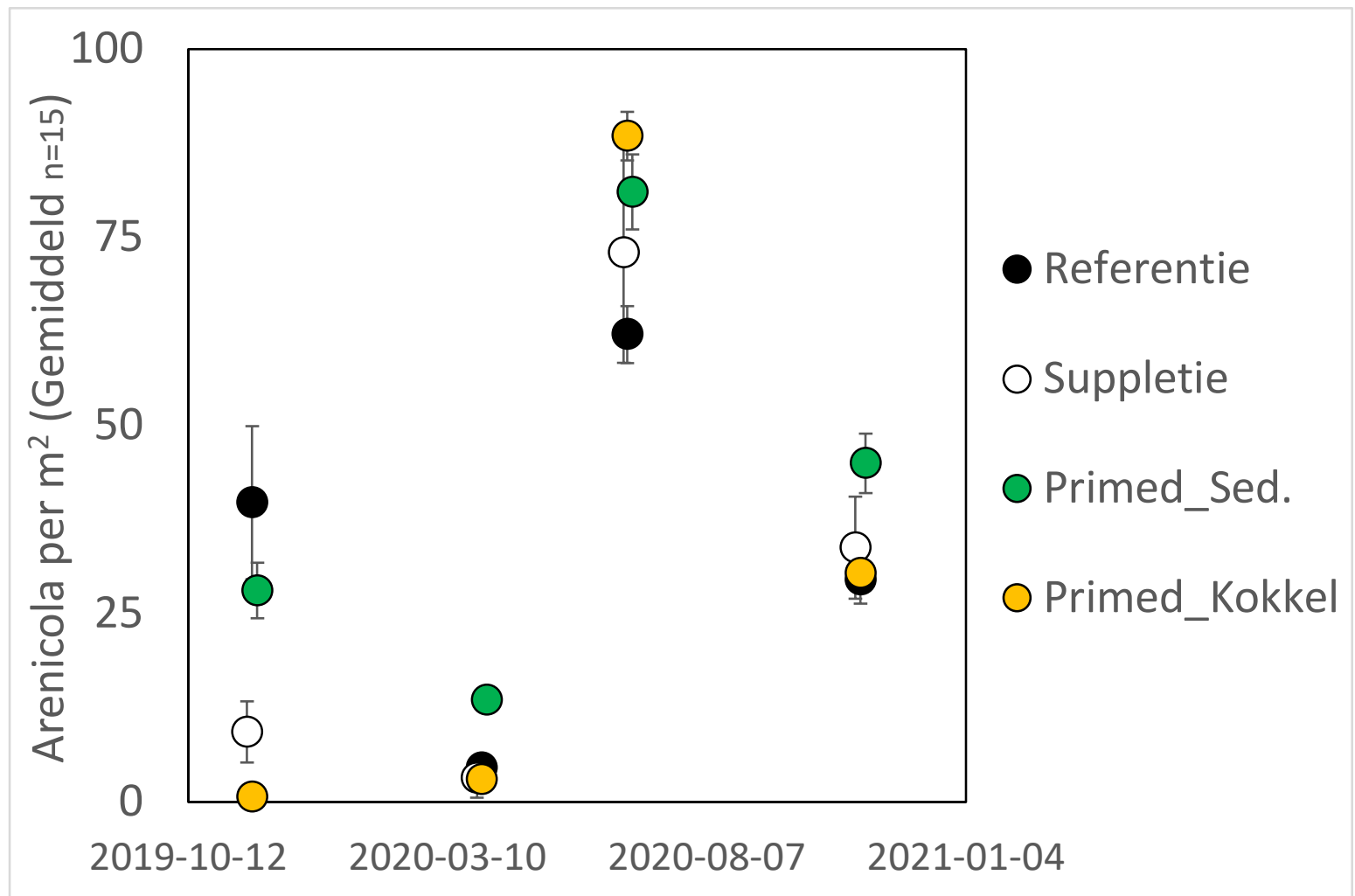

Figuur 6-56 Wadpier hoopjes over de tijd.

\subsubsection{Resultaten: kokkel priming}

Kokkeldichtheden variëren sterk tussen locaties (Figuur 6-57). In november 2019 was de gemiddelde dichtheid $164 \pm 168$ individuen per $\mathrm{m}^{2}$, gevolgd door $137 \pm 111$ 
individuen per $\mathrm{m}^{2}$ in maart 2020 en een sterke afgenomen dichtheid in juni naar gemiddeld $30 \pm 18$ individuen per $\mathrm{m}^{2}$. Dichtheden van tapijtschelpen namen tussen november 2019 en maart 2020 juist toe. Net als bij kokkels namen ook tapijtschelpen sterk af tussen maart en juni. Een eerdere proef met verzaaien van kokkels in de Westerschelde (Kesteloo, 2004) laat ook een afname in dichtheden zien over de tijd, met 136 individuen per $\mathrm{m}^{2}$ in november, naar 59 in februari, 68 in mei en 52 in augustus. De gemiddelde afname van $60 \%$ in Kesteloo (2004) ligt een stuk lager dan onze afname van $82 \%$.

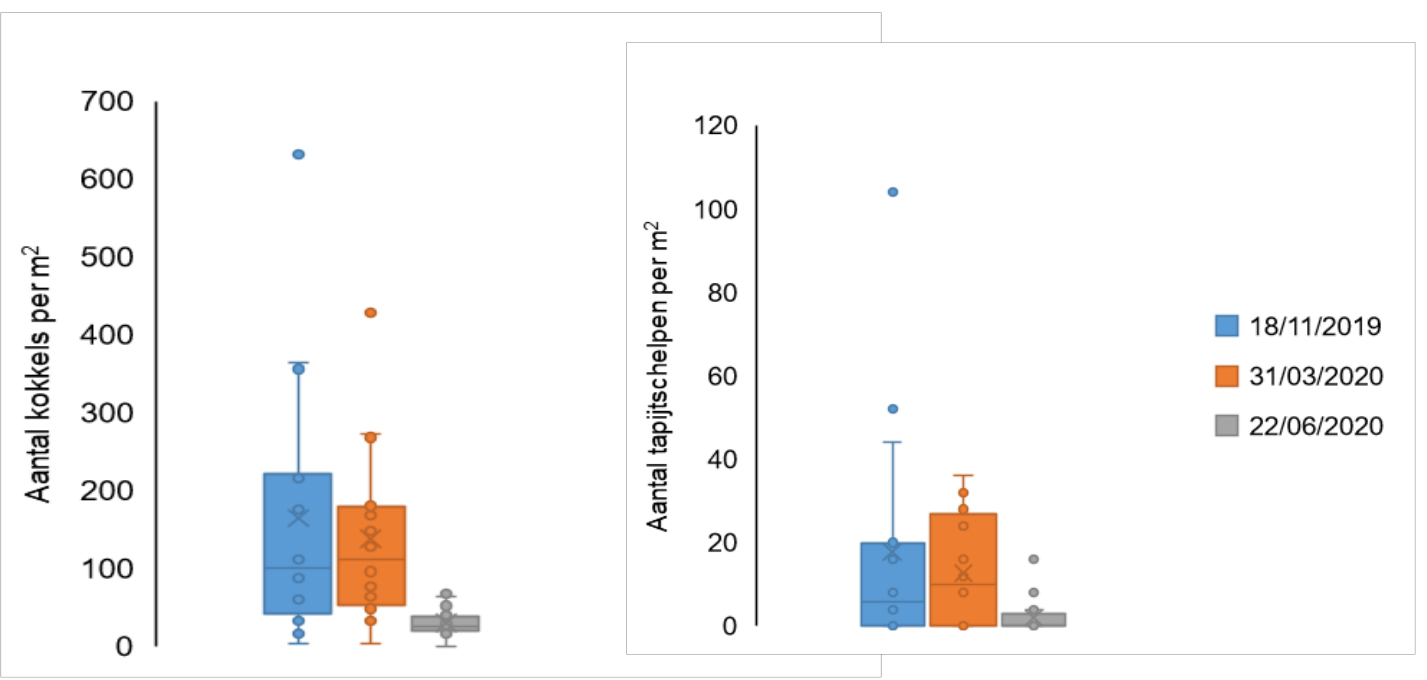

Figuur 6-57 Boxplot van kokkel (links) en tapijtschelp (rechts) dichtheden (ind. per $\mathrm{m}^{2}$ ) een week, 4 maanden en 7 maanden na de priming.

De gemiddelde schelplengtes van kokkels over de gehele meetperiode blijft nagenoeg gelijk. Wel is te zien dat de spreiding tussen lengtes in juni zijn toegenomen (Figuur 6-58). In juni zijn kleinere kokkels waargenomen, er is dus sprake geweest van een nieuwe aanwas.

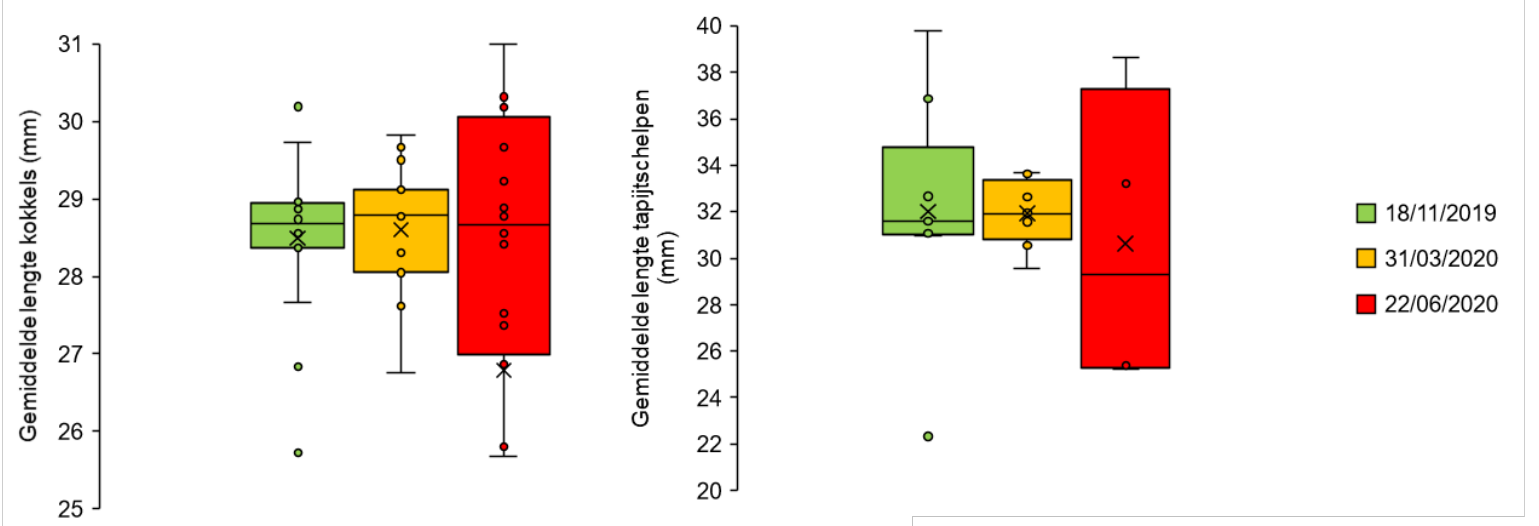

Figuur 6-58 Boxplot van schelplengtes (in $\mathrm{mm}$ ) van kokkels (links) en tapijtschelpen (rechts) een week, 4 maanden en 7 maanden naar de priming.

Totale biomassa neemt af gedurende de meetperiode (Figuur 6-59). Kort na het inzaaien is de totale biomassa gemiddeld $46.4 \pm 47.6 \mathrm{~g}$ per $\mathrm{m}^{2}$. Vier maanden later is de totale biomassa bijna gehalveerd na gemiddeld $29.4 \pm 24.9 \mathrm{~g}$ per $\mathrm{m}^{2}$ en zeven maanden na inzaaien wordt slechts $1 / 6$ deel $\left(7.7 \pm 4.9 \mathrm{~g}\right.$ per $\left.\mathrm{m}^{2}\right)$ van de ingezaaide biomassa teruggevonden. Gemiddelde biomassa per kokkel laat zien dat gewichten afnamen tussen november 2019 en maart 2020, waarna ze weer toenamen in juni 2020 (Figuur 6-59). 


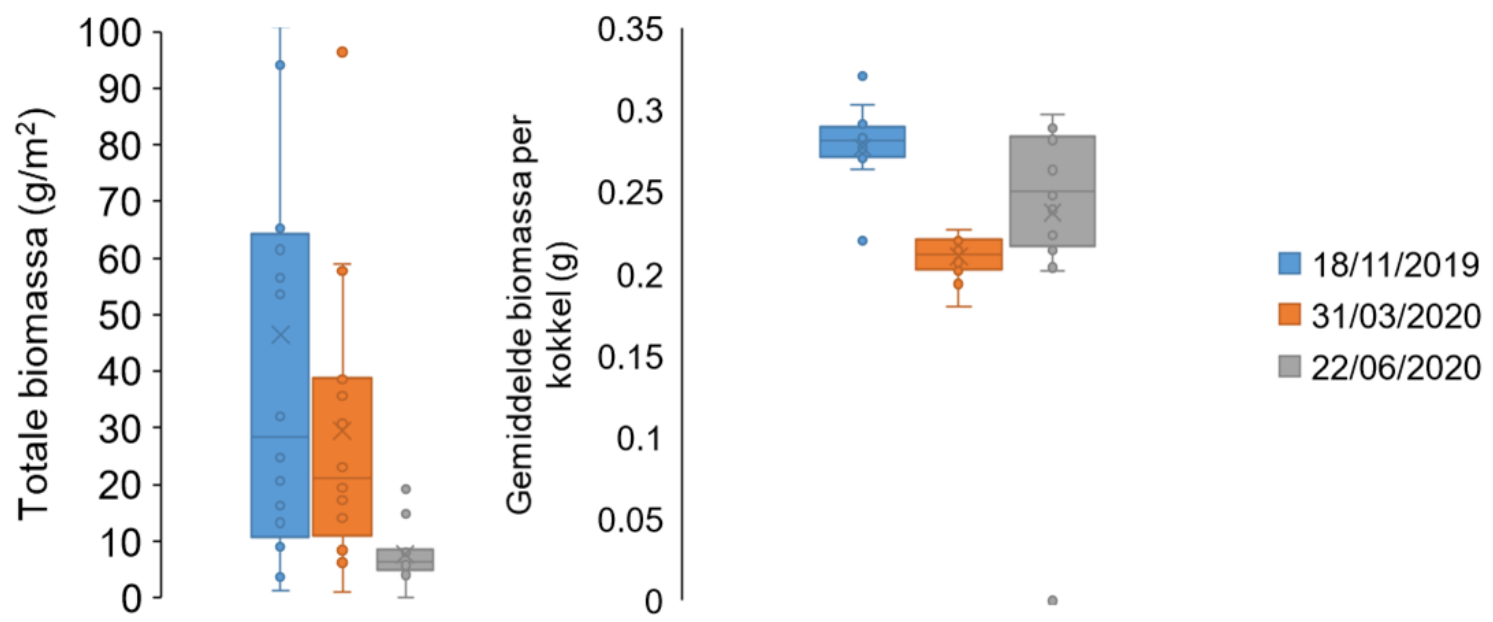

Figuur 6-59 Boxplot van totale biomasssa in $\mathrm{g}$ per $\mathrm{m}^{2}$ (links) en gemiddelde biomassa in $\mathrm{g}$ per kokkel (rechts).

Dat kokkels gedurende de winter in gewicht afnemen is een bekend fenomeen (Coosen et al. 1994). Dit zou de afname tussen november en maart, en de toename tussen maart en juni in gemiddelde biomassa per kokkel kunnen verklaren. Deze dip in biomassa werd ook door Kesteloo (2004) geobserveerd. Echter is er geen duidelijke verklaring gevonden voor de drastische afname totale biomassa tussen maart en juni 2020. Een mogelijke verklaring zou zijn dat tijdens het paaiseizoen, dat van april-juni loopt, kokkels verzwakt raken en mogelijk sterven. Hierbij spelen omgevingsfactoren een belangrijke rol. Echter laten de aangetroffen kokkels in juni geen vermagerd beeld zien. Tijdens de veldbemonstering is het wel opgevallen dat kokkels vooral aanwezig waren in sedimenten nabij geultjes en poeltjes die permanent onder water stonden.

\subsubsection{Resultaten: 3D altimetrie}

Zoals eerder aangegeven worden gebieden met stagnant water bij het maken van lazerscans weergegeven als "geen data" (= zwart in Figuur 6-60). Dit komt door het niet goed reflecteren van de laserstraal door water. Uit de kleurverdeling, met achterliggende data, blijkt dat de hoogteverandering minimaal is, zoals ook al naar voren komt uit de SED sensoren en dGPS metingen. Er is wel duidelijke opslibbing/betere afwatering te zien in de twee aangegeven priming plots. Zoals eerder vernoemd ontstaan er nieuwe afwatering geulen die in Figuur 6-49 en Figuur 6-50 duidelijk ten oosten van suppletie twee te zien zijn. 

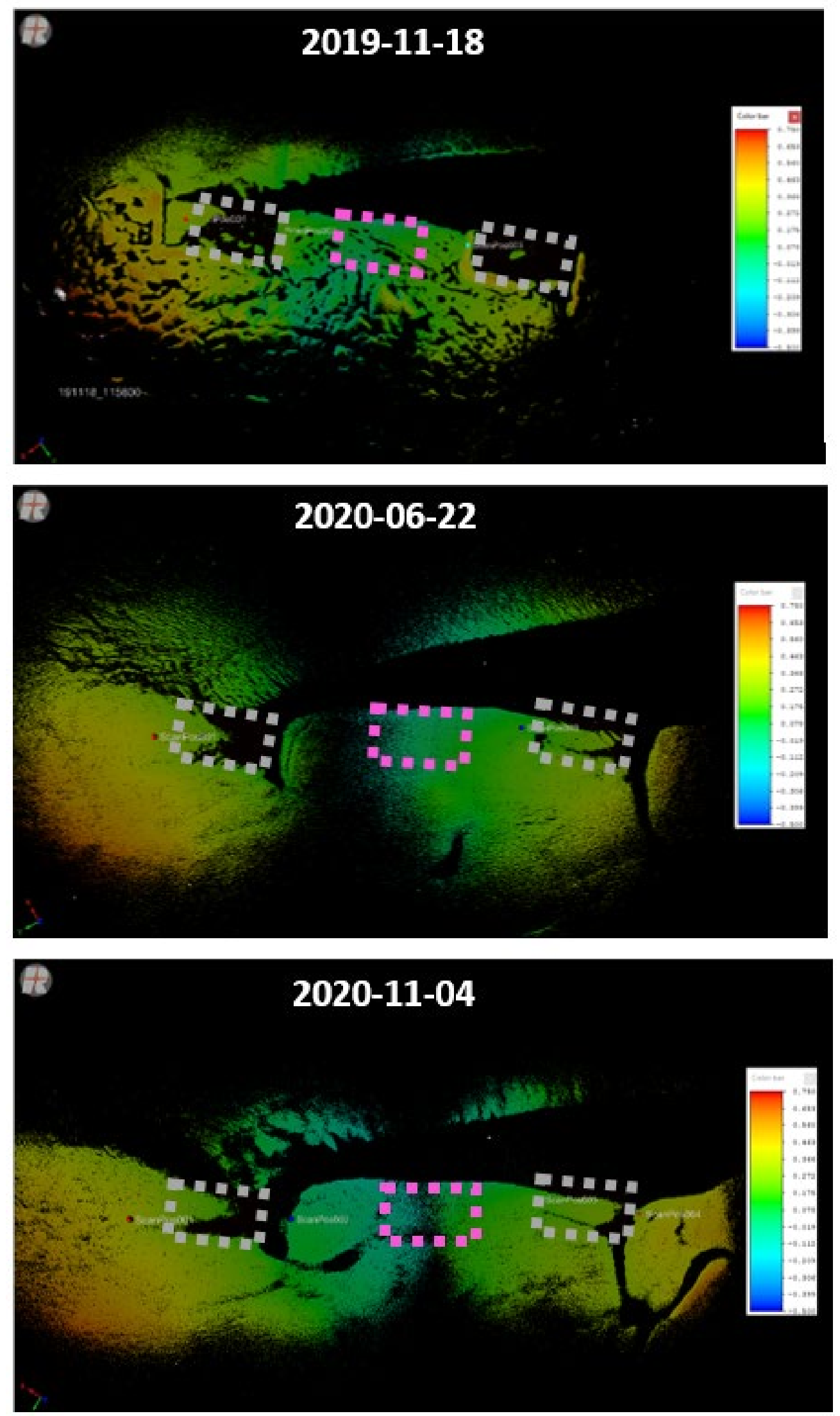

Figuur 6-60 Visualisatie van 3D-scans, met grijze stippellijn zijn primg plots 1 en 2 aangegeven en met de roze stippellijn suppletieplot 1. 


\subsubsection{Kokkelbestand Roggenplaat}

\subsubsection{Methode}

Om inzicht te krijgen in de schelpdierbestanden, specifiek de kokkels en oesters, op de Roggenplaat, is gebruik gemaakt van de WOT bestandopnames van Wageningen Marine Research, zie Walles et al. 2021. In Figuur 6-61 is te zien dat het in het bemonsteringsgrid van de kokkelbestandsopname de suppleties nauwelijks vertegenwoordigd zijn, met nul tot maximaal drie monsterpunten per suppletie. De WOT bemonstering zal hierdoor weinig inzicht geven over het effect van de suppleties op het kokkelbestand per suppletie. Wel geeft het een beeld van het totale bestand aan kokkels op de Roggenplaat in vergelijking tot de gehele Oosterschelde.

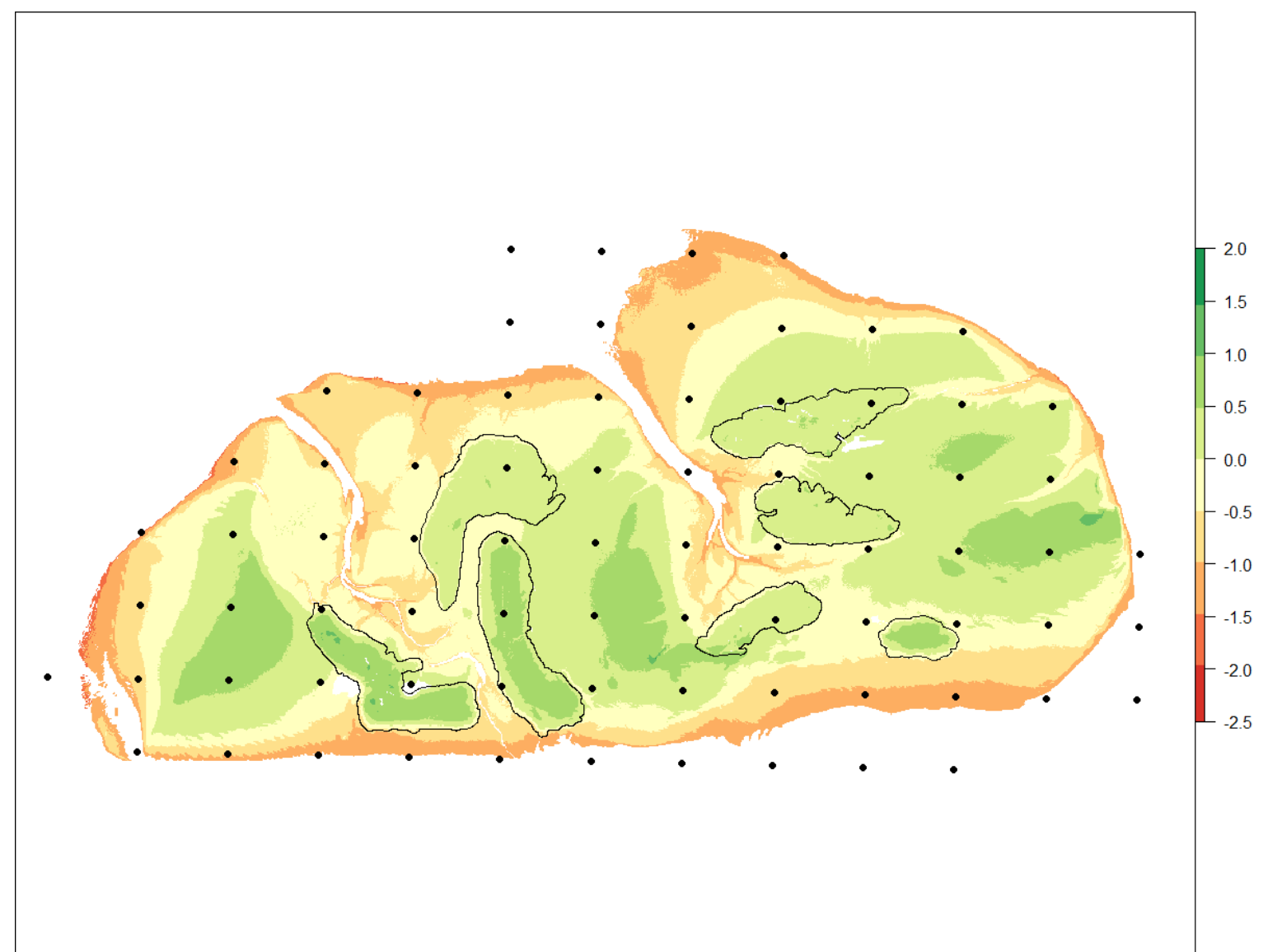

Figuur 6-61. Bemonsteringsgrid kokkelbestandsopname Roggenplaat. Achtergrond kaart LiDAR 2020. Zwarte lijn geeft contouren van de suppleties weer.

\subsubsection{Resultaten}

De jaar tot jaar variatie op de Roggenplaat correspondeert met de jaar tot jaar variatie waargenomen voor de gehele Oosterschelde (Figuur 6-62). De Roggenplaat draagt gemiddeld $26.7 \pm 1.7 \%$ (mean $\pm \mathrm{se}$ ) bij aan het totale kokkelbestand van de Oosterschelde. In 2020 daalde het aandeel van het totale kokkelbestand dat op de Roggenplaat ligt (Figuur 6-63). Gezien het kleine percentage van de monsterpunten op de suppletie, is dit waarschijnlijk niet toe te schrijven aan de suppleties. Een daling kan door jaar tot jaar variatie verklaard worden, of door verhoogde sterfte in 2019. Het percentage van voorkomen van kokkels op de Roggenplaat tussen 2015 en 2020 is het hoogst in het midden van de plaat (Figuur 6-64). Over de periode 2015-2020 werden hoogste biomassa's aangetroffen aan de oostkant van de Roggenplaat en midden op de plaat (Figuur 6-65). De 1-, 2- en meerjarige kokkels zijn hoofdzakelijk te vinden in het 
oostelijke deel van de Roggenplaat in 2020 (Figuur 6-66). In 2020 zien we een toename in het aantal meerjarige kokkels ten opzicht van 2019. In 2019 kwamen meerjarige kokkels nauwelijks voor op de Roggenplaat. In augustus 2018 en 2019 is massale kokkelsterfte vastgesteld in de Oosterschelde. Dit had vermoedelijk te maken met de zeer hoge temperaturen in deze periode.

Naast kokkels geeft deze bestandsopname ook informatie over andere schelpdieren. Het nonnetje Limecola balthica (Figuur 6-67) en de tapijtschelp Ruditapes philippinarum (Figuur 6-68) worden net als de kokkel frequent aangetroffen op de Roggenplaat. Beide soorten zijn erg variabel tussen de jaren. Binnen de survey wordt het nonnetje onderverdeeld in grootteklassen.

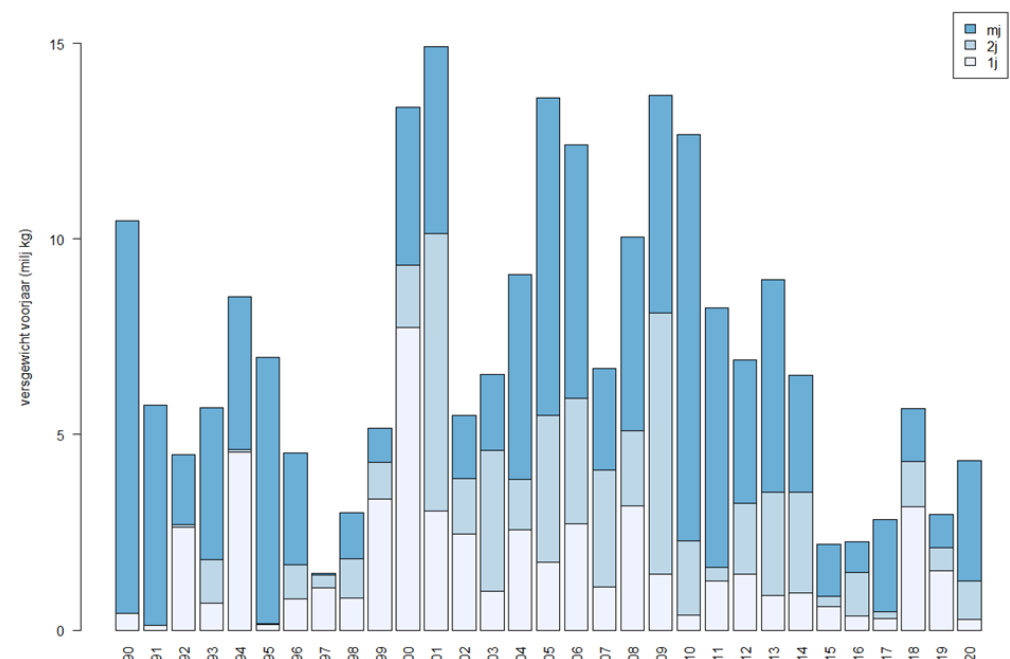

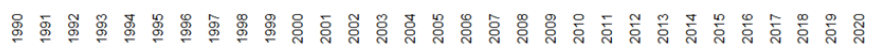

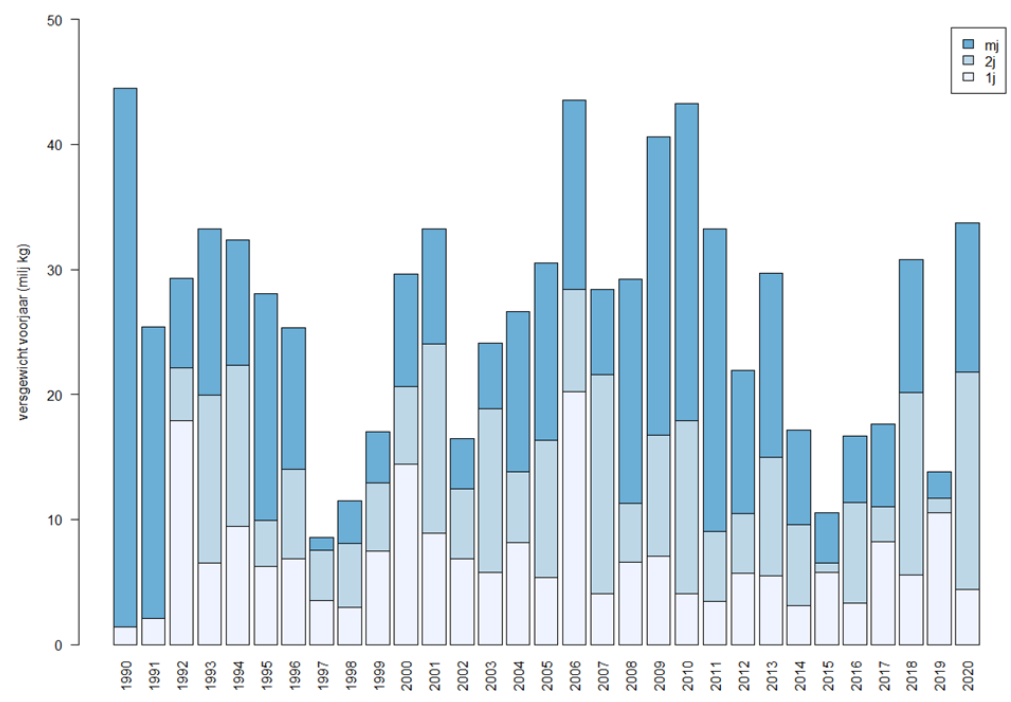

Figuur 6-62. De kokkelbiomassa (miljoen kg versgewicht) bij de voorjaarsbemonstering op de Roggenplaat (boven) en in de Oosterschelde (onder) in de periode 1990-2020, onderverdeeld in jaarklassen 1 -jarig (inclusief incidenteel aangetroffen broed $=0$ jarig), 2-jarig en meerjarig. 


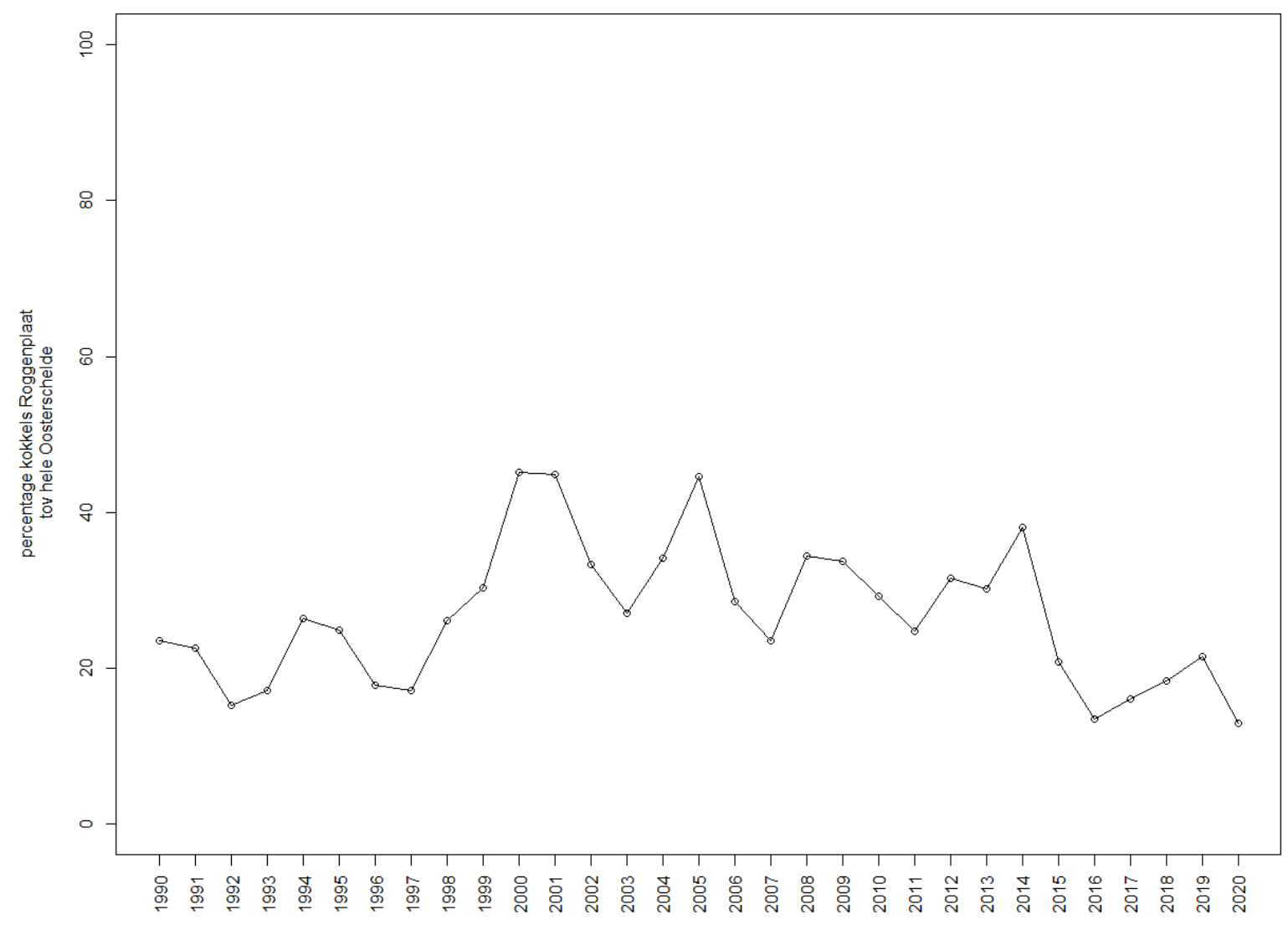

Figuur 6-63. De ontwikkeling in het aandeel kokkels, op basis van biomassa, op de Roggenplaat t.o.v. het hele Oosterschelde kokkelbestand.

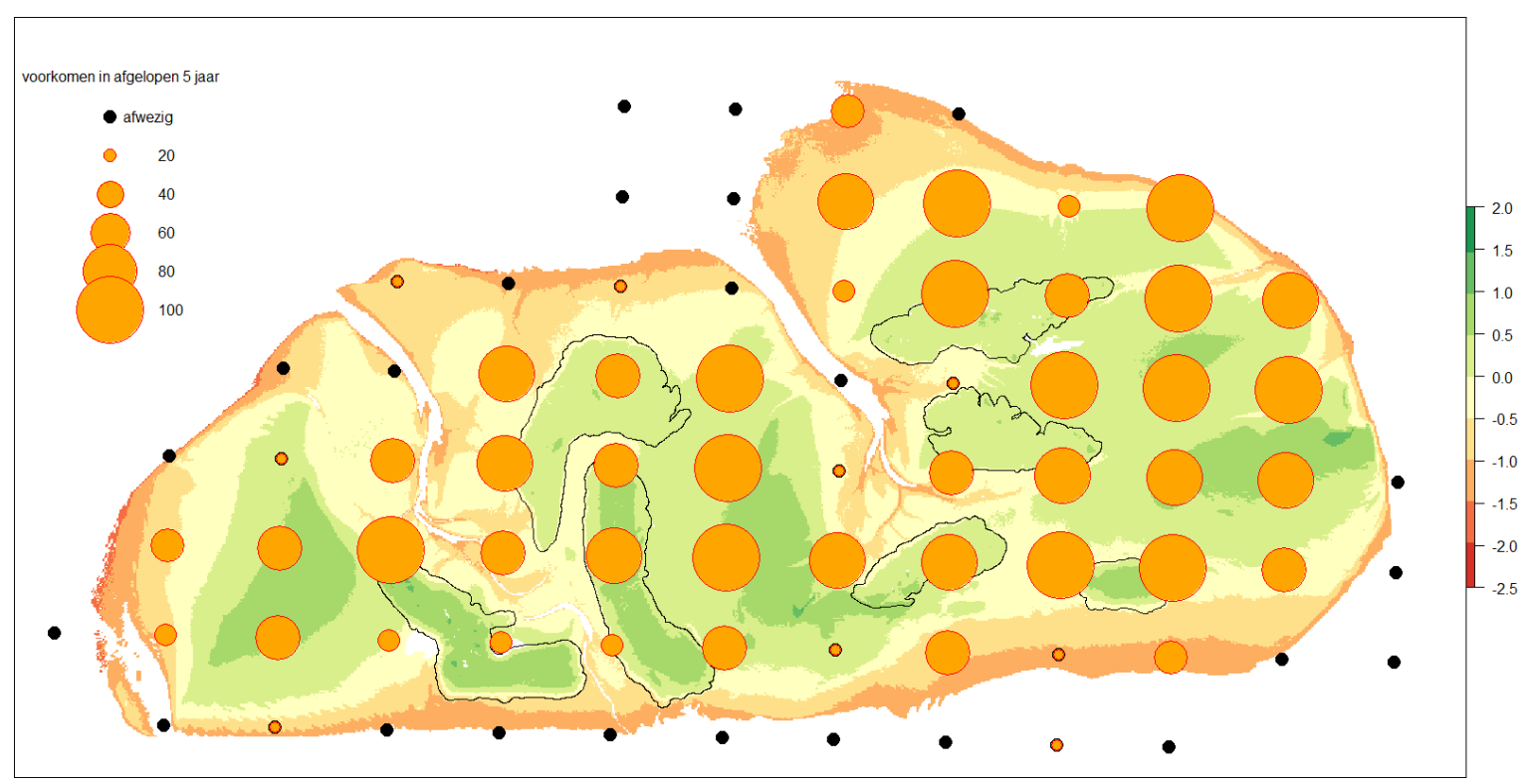

Figuur 6-64. Het percentage van voorkomen van kokkels tussen 2015 en 2020 per monsterlocatie op de Roggenplaat. 

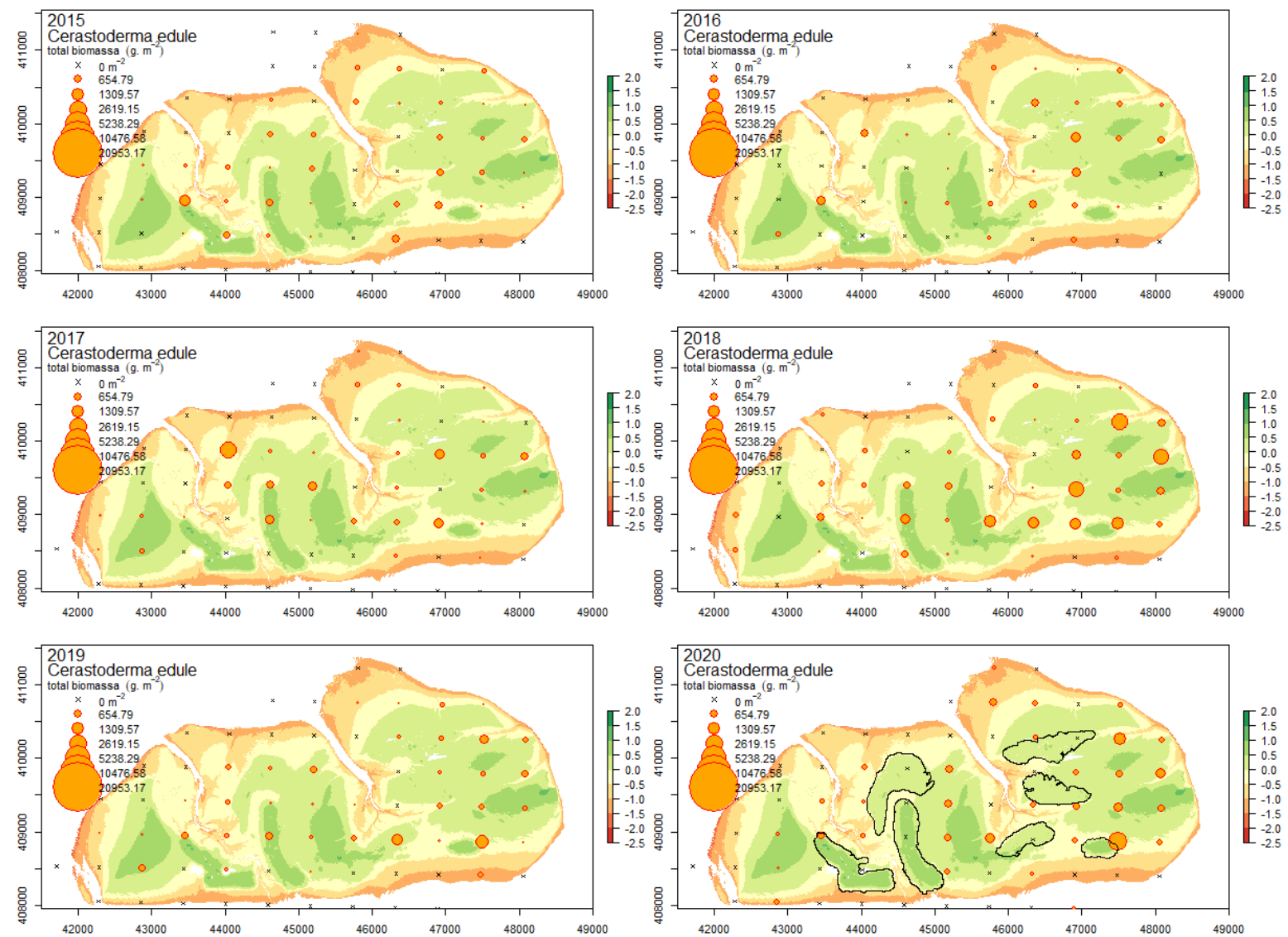

Figuur 6-65. Biomassa kokkels tussen 2015 en 2020 op de Roggenplaat.

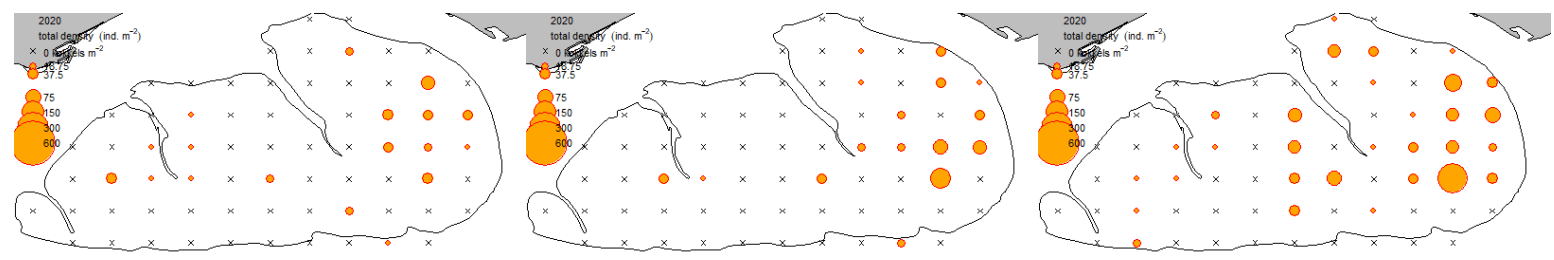

Figuur 6-66. Kokkel dichtheden voor 1 jarige (links), 2 jarige (midden) en meerjarige (rechts) kokkels in 2019. 

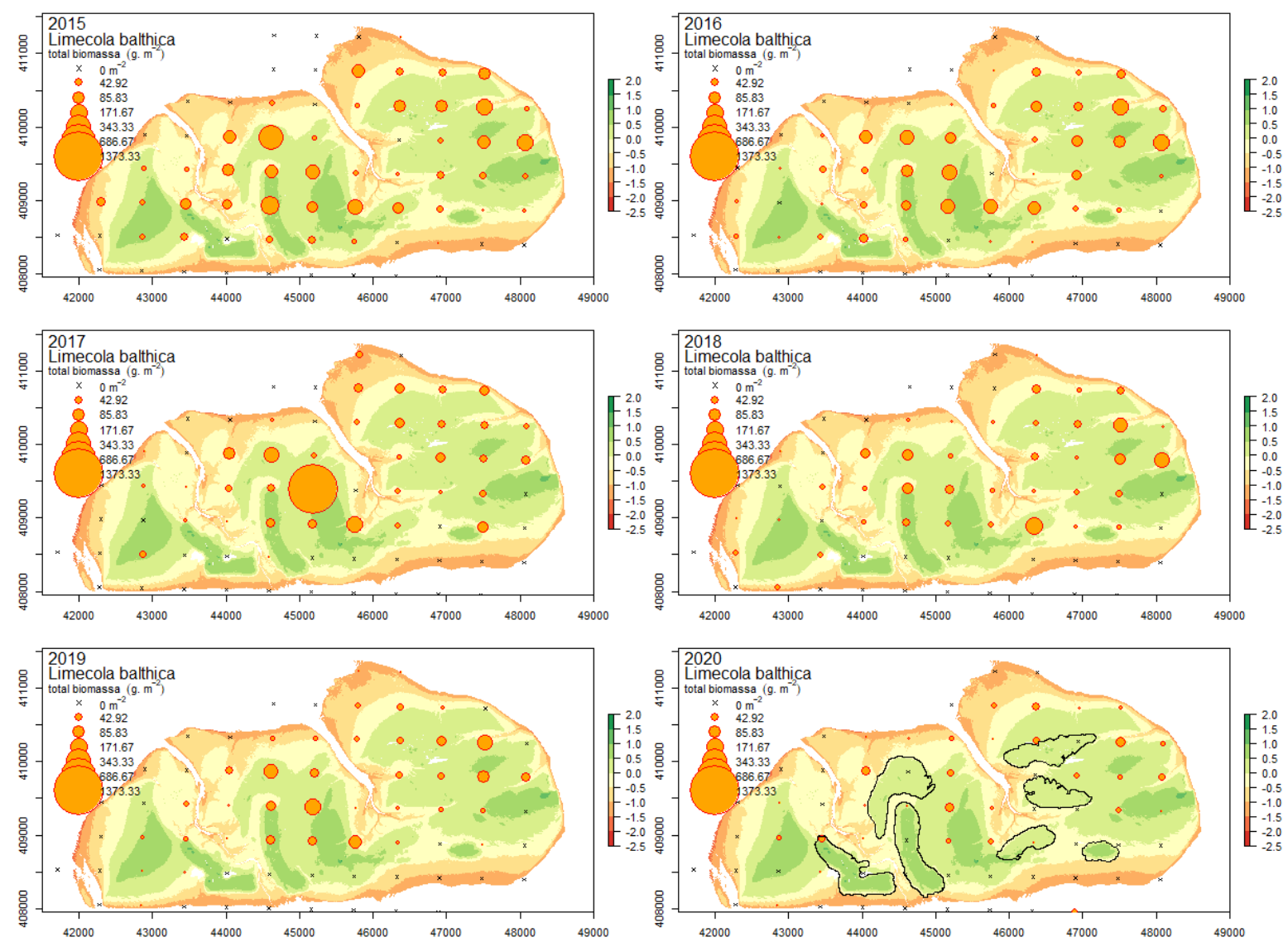

Figuur 6-67. Biomassa Nonnetjes tussen 2015 en 2020 op de Roggenplaat.
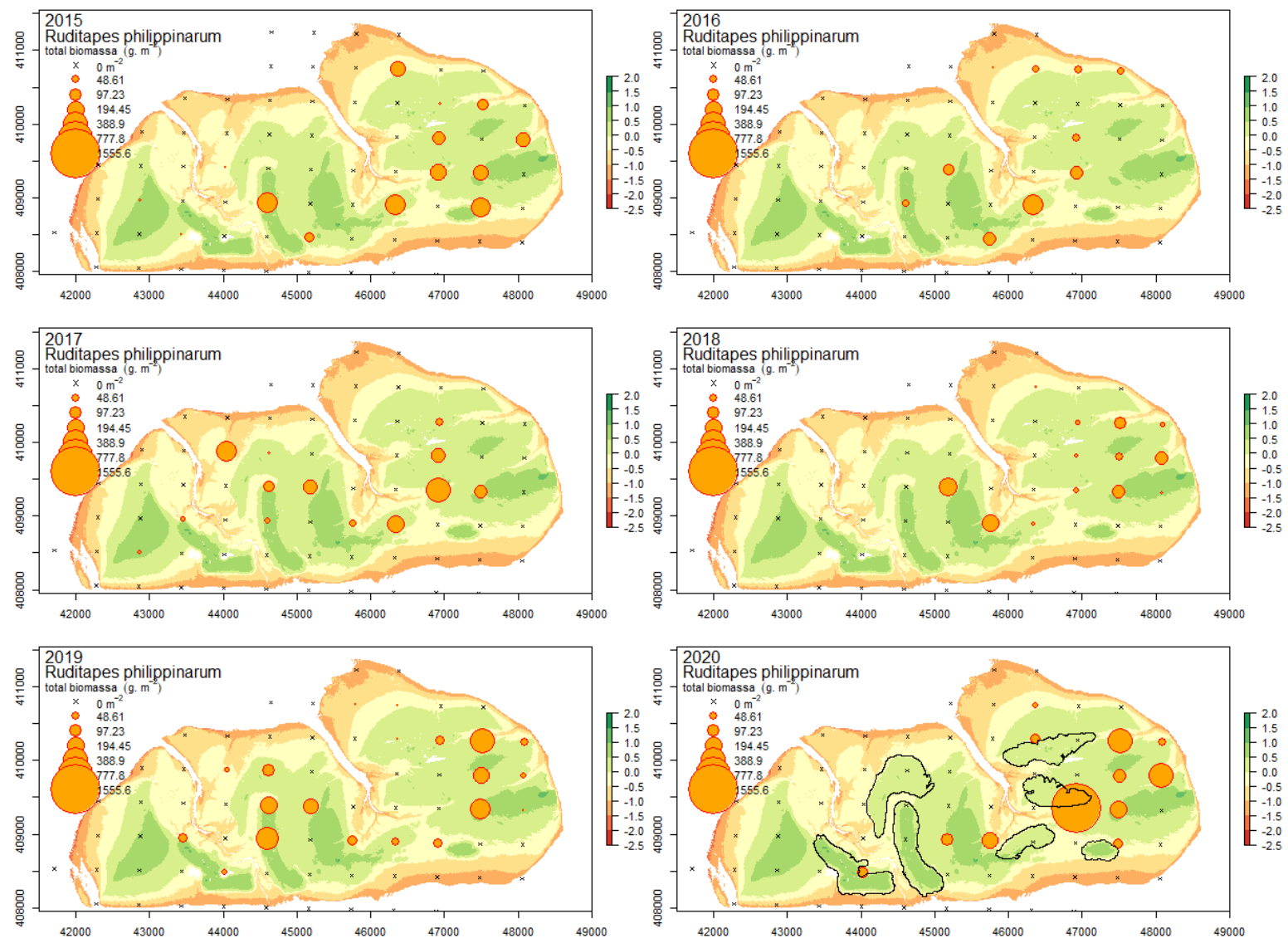

Figuur 6-68. Biomassa Tapijtschelpen tussen 2015 en 2020 op de Roggenplaat. 


\subsubsection{Oesterbanken}

\subsubsection{Methode}

Jaarlijks worden de oesterbanken in de Oosterschelde geïnventariseerd door Wageningen Marine Research als onderdeel van de Wettelijke Onderzoekstaken Visserij (WOT) in opdracht van het Ministerie van Landbouw, Natuur en Voedselkwaliteit (LNV). De banken op de Roggenplaat zijn in 2015 (op 3 riffen na), 2017, 2018 en 2020 ingemeten en in 2016 en 2019 geconstrueerd uit het voorgaande jaar, zie Walles et al. 2021.

\subsubsection{Resultaten}

Tijdens de ontwerpfase van de Roggenplaat is rekening gehouden met de aanwezigheid van oesterriffen. Omdat riffen een rijk habitat vormen en een belangrijke foerageerplek zijn voor een aantal doelsoorten is er niet gesuppleerd op de riffen. Tijdens de survey in het voorjaar van 2020, na aanleg van de suppleties, is vastgesteld dat suppletie 2, 4 en 5 de nabijgelegen oesterriffen deels bedekt hebben (Figuur 6-69). Het areaal van de Roggenplaat bedekt met oesterriffen is hierdoor met 5.7 ha afgenomen naar een totaal van 56.2 ha in 2020.

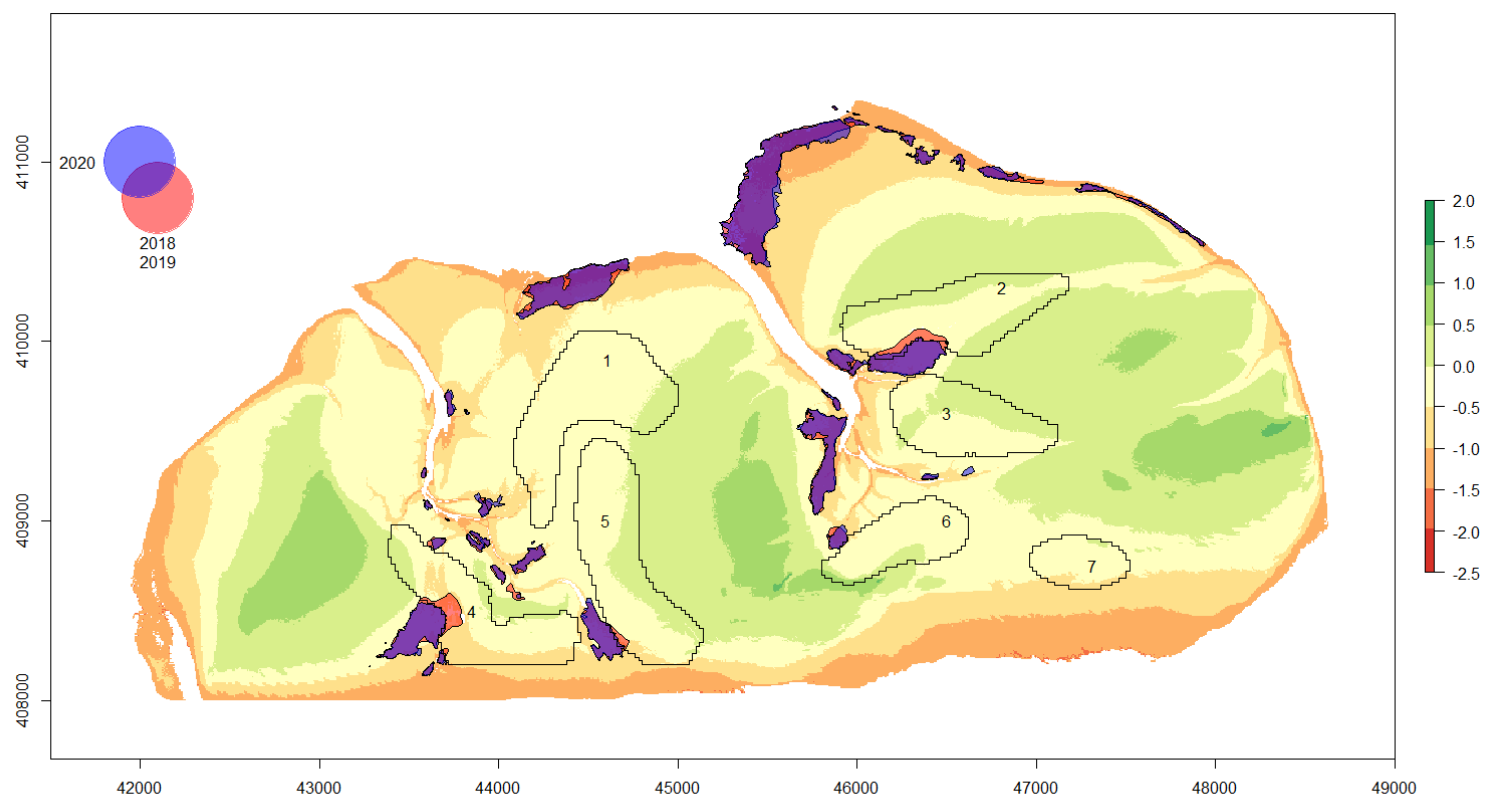

Figuur 6-69 Oesterbanken op de Roggenplaat ingelopen in 2018 en 2020. In 2019 zijn de oesterbanken gekopieerd uit 2018. De kleuren geven aan in welk jaar (rood: 2018 en 2019; blauw: 2020) de riffen geobserveerd waren. Voor banken geobserveerd in beide jaren overlappen de kleuren. De rode en blauwe gebieden geven dus afwijkingen tussen voor en na aanleg van de suppletie weer. De zwarte lijnen geven de contouren van de suppletie-elementen weer. Suppletie-element 2, 4 en 5 bedekken delen van naastgelegen riffen.

\subsubsection{Laagwaterverspreiding steltlopers}

\subsubsection{Methode}

Het uiteindelijke doel van de suppletie Roggenplaat is het in standhouden van voldoende foerageergebied voor steltlopers waarvoor de Oosterschelde van internationaal belang is (scholekster, kanoet, wulp, bonte strandloper, strandplevier, zilverplevier, rosse grutto, bontbekplevier, groenpootruiter, kluut, steenloper, tureluur en zwarte ruiter) en 
waarvoor Natura2000-doelstellingen zijn geformuleerd in het Oosterschelde beheerplan (als onderdeel van het beheerplan voor de Deltawateren). Voor deze vogels is niet alleen het areaal foerageergebied van belang, maar ook de tijdsduur die de vogels kunnen foerageren per laagwaterperiode. Ligt het gebied te laag, dan kan niet voldoende lang gefoerageerd worden om in de energiebehoefte te voorzien. Gebieden die bijna de hele tijd droog liggen bevatten daarentegen over het algemeen weinig bodemdieren. Daarom zijn gebieden met de droogvalduurklasse $40-80 \%$ cruciaal. Verwacht wordt dat de suppletie voorziet in gebied met de juiste droogvalduur, maar dat hogere aantallen pas waargenomen worden na herstel van het bomemdierleven. Hiervoor zijn laagwatertellingen uitgevoerd, waarbij per teldatum de vogels driemaal geteld zijn. Zie voor de gebruikte telmethode en data-analyse Walles et al. (2021). Er zijn 34 tellingen uitgevoerd in de periode november 2015 - november 2020. Tussen 2015-2019 voor de suppleties zijn 25 tellingen uitgevoerd. Tijdens de suppleties zijn 4 tellingen uitgevoerd en na de suppleties 7 tellingen. Tellingen in december 2020 en januari 2021 waren wel gepland, maar zijn niet uitgevoerd wegens weersomstandigheden. Voor de analyse is een selectie gemaakt van soorten die structureel geteld zijn en gebruik maken van de Roggenplaat als foerageergebied. Soorten die hierdoor niet zijn meegenomen in de analyse, zijn viseters, roofvogels, grondeleenden en steltopers zoals kievit en goudplevier die de Roggenplaat vooral als rustplek gebruiken. Verder zijn een aantal uitermate zeldzame steltlopers weggelaten uit de analyse. Meeuwen zijn wel meegenomen. Alhoewel de focus niet op deze soorten ligt, maken zij wel gebruik van de Roggenplaat als foerageergebied. Om vogeltellingen te kunnen vergelijken met benthosdichtheden, hebben we gemiddelde vogeldichtheden per hectare berekend over de herfst en wintermaanden (oktober-februari) en vergeleken met de benthosdichtheid binnen een hectare, die bemonsterd in september. Waar meerdere benthos monsterpunten in een hectare lagen is de gemiddelde benthosdichtheid gebruikt.

\subsubsection{Resultaten: Soorten en aantallen}

In totaal zijn er 65 vogelsoorten geteld op de Roggenplaat voor de suppletie. Omdat maar een deel van de vogelsoorten daadwerkelijk foerageert op de Roggenplaat, is de verdere analyse uitgevoerd met deze selectie van 26 soorten. Van deze soorten zijn 20 soorten 5 teldagen of meer geteld voor de suppleties (Tabel 10). Met name bonte strandloper, rosse grutto, scholekster, wulp en zilverplevier komen veel voor op de Roggenplaat (gemiddeld meer dan 1700 individuen per soort). Opvallende veranderingen ten opzichte van de getallen voor aanleg zijn relatief hoge aantallen zilverplevieren na de suppleties (in groen) en relatief lage aantallen rosse grutto's (in oranje) (Tabel 10).

De variatie tussen tellingen is groot, maar het seizoensverloop is gelijk over de verschillende maanden voor en na aanleg (Figuur 6-70). In mei is het gemiddelde echter duidelijk lager. Ook in februari zakt het gemiddelde iets. Het gemiddelde van maart voor aanleg is hoger; dit wordt veroorzaakt door één telling (Bijlage 8, Figuur 10-1). Aantallen vogels lijken tot nu toe vergelijkbaar voor, tijdens en na de suppletie. Eén telling in november tijdens de aanleg van de suppletie en de telling in oktober na de suppletie vallen vrij hoog uit. De telling na de suppletie in november is daarentegen weer enigszins laag. Bij deze grafiek moet worden aangemerkt dat de manier van tellen meer gericht is op soortsamenstelling en gebiedsgebruik dan het schatten van aantallen. Het gemiddeld aantal soorten fluctueert maar ligt meestal tussen de 15 en 20 soorten per teldag. Aantallen soorten voor, tijdens en na de suppletie zijn in de meeste maanden vergelijkbaar, maar na de suppletie zijn er iets minder soorten gezien dan gemiddeld in maart, mei en augustus (Figuur 6-71). 
Tabel 10. Vogelsoorten die 5 teldagen of vaker geobserveerd zijn op de Roggenplaat voor en na aanleg van de suppleties. Het gaat hier om soorten die foerageren op de Roggenplaat en structureel geteld zijn. De kolom Natura-2000 doel geeft aan of instandhoudingsdoelstellingen wel of niet behaald worden voor deze soort in de Oosterschelde. Vogels staan geordend van hoogst naar laagst gemiddelde dagmaximum voor de suppleties. De schuingedrukte soorten, steltlopers, zijn later meegenomen in de samenstelling van soorten over de tijd. Deze soorten komen 40 procent van de teldagen of vaker voor op de Roggenplaat.

\begin{tabular}{|c|c|c|c|c|c|c|}
\hline Soort & \multicolumn{3}{|c|}{ VOOR } & \multicolumn{3}{|c|}{ NA SUPPLETIE } \\
\hline Bonte strandloper & 25 & 4838 & 12341 & 5254 & 7842 & $\mathrm{Ja}$ \\
\hline Rosse grutto & 25 & 2690 & 5417 & 1805 & 2889 & $\mathrm{Ja}$ \\
\hline Zilverplevier & 25 & 1787 & 3309 & 2369 & 6345 & Ja \\
\hline Kokmeeuw & 21 & 1338 & 8668 & 1885 & 7454 & Nee \\
\hline Kanoetstrandloper & 25 & 1056 & 8705 & 1003 & 2560 & Ja \\
\hline Zilvermeeuw & 21 & 729 & 2661 & 862 & 2436 & Nee \\
\hline Stormmeeuw & 20 & 133 & 511 & 190 & 575 & Nee \\
\hline Bergeend & 23 & 68 & 815 & 187 & 1204 & Ja \\
\hline Tureluur & 23 & 43 & 174 & 29 & 68 & Ja \\
\hline Bontbekplevier & 17 & 28 & 144 & 14 & 37 & Ja \\
\hline Lepelaar & 15 & 19 & 144 & 9 & 32 & Ja \\
\hline Grote mantelmeeuw & 21 & 19 & 72 & 15 & 38 & Ja \\
\hline Steenloper & 22 & 8 & 40 & 4 & 15 & Ja \\
\hline $\begin{array}{l}\text { Kleine } \\
\text { mantelmeeuw }\end{array}$ & 14 & 5 & 29 & 4 & 12 & Nee \\
\hline
\end{tabular}

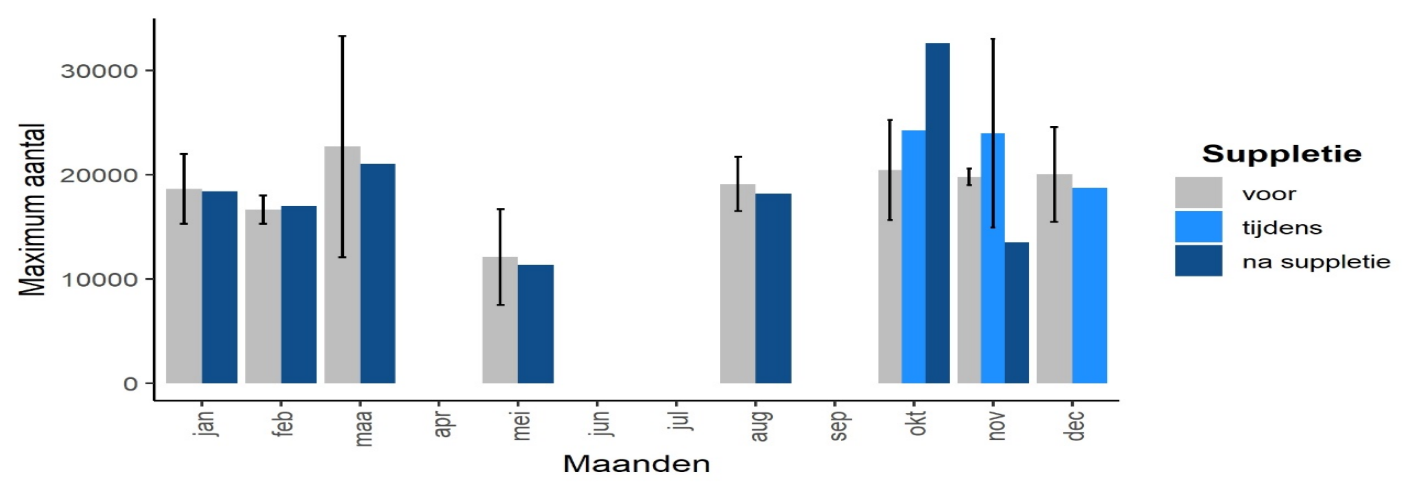

Figuur 6-70 Gemiddelde maximale aantallen per maand en hun standaard deviatie voor, tijdens en na aanleg van de suppleties. Voor de berekening van totaal aantal vogels hebben we eerst het totaal aantal getelde individuen per soort geselecteerd per teldatum en telmoment over het getij (telperiodes), en vervolgens het maximaal per soort geselecteerd en bij elkaar opgeteld. Tussen 2015 en 2019 (voor aanleg van de suppleties) is in oktober twee keer geteld, in de andere maanden drie of vier keer. In maart 2017 is er tweemaal geteld en in november 2019 tweemaal (tijdens de aanleg van de suppleties). Na de suppletie zijn er geen dubbele tellingen binnen een maand. 


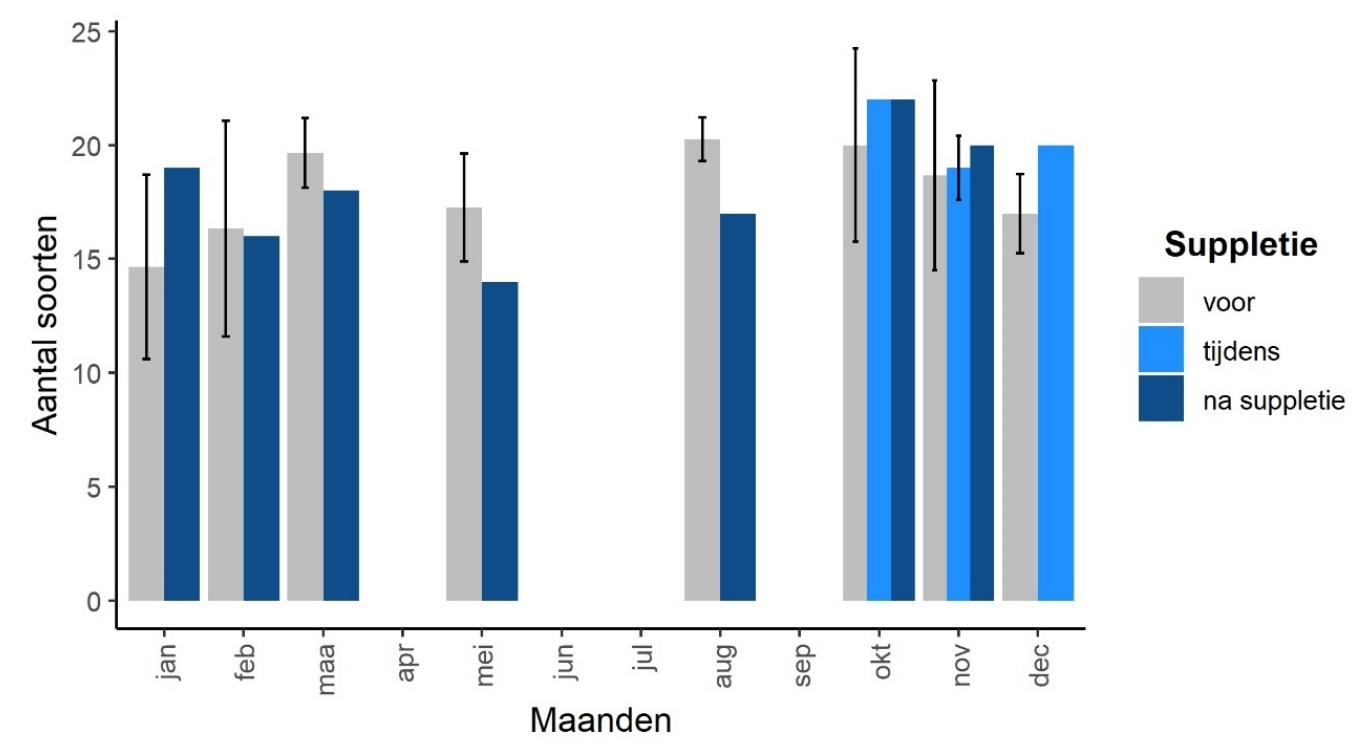

Figuur 6-71 Gemiddeld aantal soorten per maand met standaard deviatie voor, tijdens en na aanleg van de suppleties. Tussen 2015 en 2019 (voor aanleg van de suppleties) is in oktober twee keer geteld, in de andere maanden drie of vier keer. In maart 2017 is er tweemaal geteld en in november 2019 tweemaal (tijdens de aanleg van de suppleties).

De soortensamenstelling verandert over het seizoen (Figuur 6-72 en Figuur 6-73), alhoewel we hier ook soms fluctuaties zien tussen jaren en binnen maanden (Bijlage 8 , Figuur 10-2). De zomer (augustus) wordt gekenmerkt door veel kokmeeuwen die in de andere maanden bijna afwezig zijn en lage aantallen van de anders frequente bonte strandloper (Figuur 6-72). De scholekster en wulp vertonen beide een piek in augustus en oktober. In de wintermaanden november tot en met januari is de soortsamenstelling vrij constant. In deze maanden is de bonte strandloper de meest algemene soort. In het vroege voorjaar (februari, maart) neemt de kanoetstrandloper iets toe en de scholekster en bonte strandloper iets af in aantallen. In mei bezoeken grote aantallen rosse grutto's en zilverplevieren het gebied op weg naar hun noordelijke broedgebieden.

De suppletie lijkt in grote lijnen niet veel invloed te hebben gehad op de soortsamenstelling van de meest algemene soorten. De meeste soorten tonen tijdens en na de suppletie geen afwijkingen in hun seizoenspatroon vergeleken met voor de suppletie (Figuur 6-73). Tijdens de suppleties valt de grote groep zilvermeeuwen in oktober op. Verder is er na de suppletie in augustus 2020 een opvallend grote groep bergeenden gezien, en zijn er meer zilverplevieren dan gebruikelijk in oktober na de suppleties. De groenpootruiter lijkt wat achteruit te zijn gegaan, maar aantallen waren voor de aanleg ook al laag. 


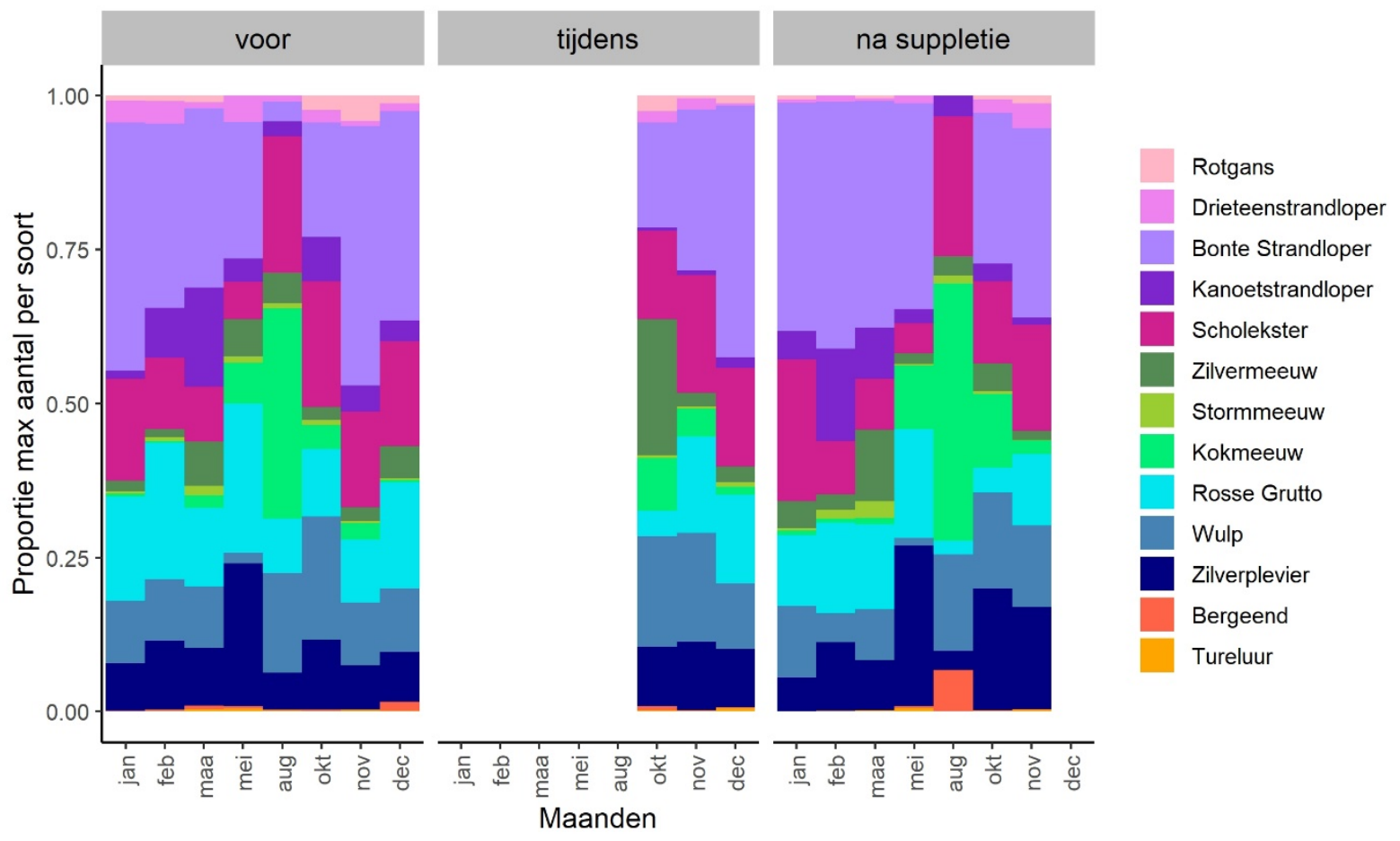

Figuur 6-72 Gemiddelde maximale aantallen per maand voor 13 geselecteerde soorten voor, tijdens en na aanleg van de suppleties. De 13 soorten zijn geselecteerd op hun gemiddelde maximale aantallen voor de suppletie (zie Tabel 10). Tussen 2015 en 2019 (voor aanleg van de suppleties) is in oktober twee keer geteld, in de andere maanden drie of vier keer. In maart 2017 is er tweemaal geteld en in november 2019 tweemaal (tijdens de aanleg van de suppleties). 

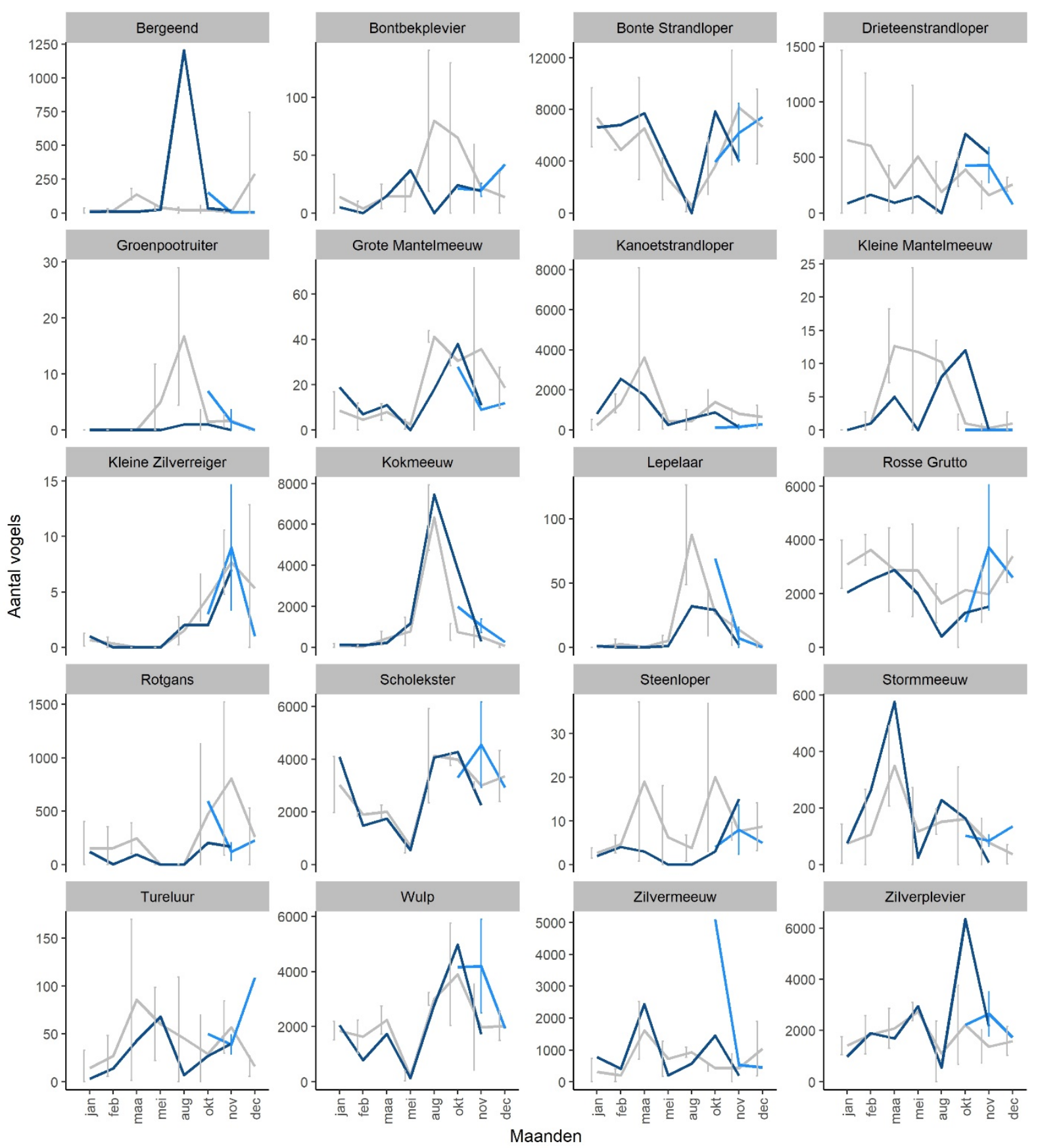

$$
\text { Suppletie - voor }- \text { tijdens }- \text { na suppletie }
$$

Figuur 6-73 Verloop van 20 meest voorkomende soorten per maand (in alfabetische volgorde) over alle getelde maanden voor, tijdens en na aanleg van de suppleties. Gemiddeldes met de standaard deviatie zijn getoond.

Aantallen vogels fluctueren over de drie telperiodes over het getij (Figuur 6-74, links). De meeste vogels zijn op de Roggenplaat te vinden in telperiode 2 en 3. In de eerste telperiode is het percentage foeragerende vogels kleiner dan in telperiode 2 en 3 ten opzichte van rustende vogels (Figuur 6-74, rechts). In de eerste telperiode voor aanleg van de suppleties ligt het percentage foeragerende vogels rond de 60 procent, in telperiode 2 en 3 gaat dit omhoog naar meer dan $90 \%$. Dit patroon is te zien in alle maanden, maar met name het percentage foeragerende vogels in telperiode 1 fluctueert nogal. $\mathrm{Er}$ is geen duidelijke relatie tussen het percentage foeragerende vogels en koude of warmere maanden (Bijlage 8 ). Het patroon over de telperiodes blijft hetzelfde tijdens en na de suppletie. In telperiode 1 zitten er na de suppletie gemiddeld iets minder vogels 
dan voor de suppletie. Omdat de totale aantallen na de suppletie niet afwijken, kan dit een aanwijzing zijn dat vogels het gebied minder lang bezoeken tijdens laagwater. Daarnaast rusten vogels in telperiode 1 tijdens de suppletie percentueel iets vaker vergeleken met eerdere observaties.
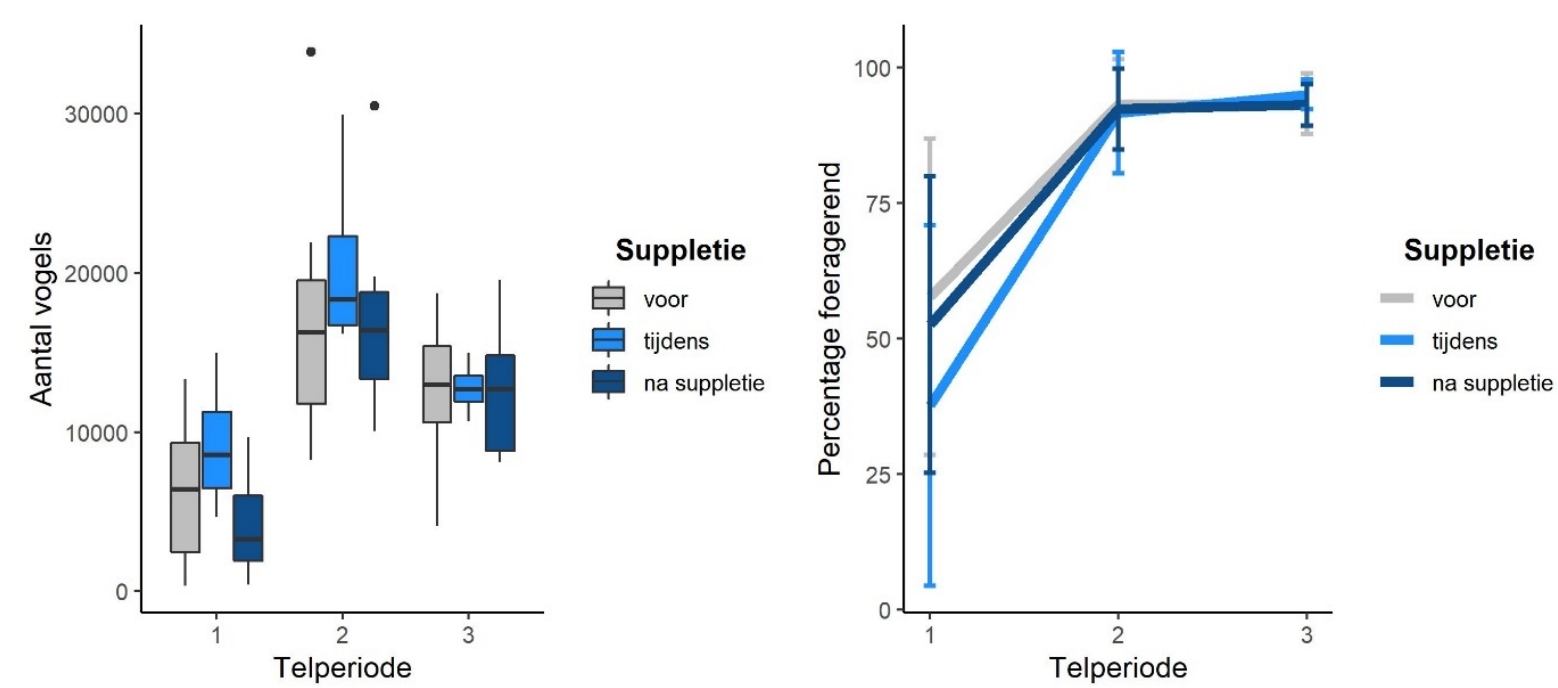

Figuur 6-74 Aantal vogels per telperiode (links) en de percentage foeragerende vogels per telperiode (rechts) voor, tijdens en na de aanleg van de suppleties. Telperiode 1 is 0 tot 2 uur na hoogwater, telperiode 2 is 2 tot 4 uur na hoogwater en telperiode 3 is 4 tot 6 uur na hoogwater.

\subsubsection{Resultaten: Ruimtelijke verspreiding}

Niet elk gebied van de Roggenplaat wordt evenveel gebruikt door de vogels. Alhoewel er enige verschillen zijn tussen de maanden, zijn de hoogste aantallen vogels over het algemeen te vinden op de oost- en zuidkant van de Roggenplaat, en de laagste aantallen vogels op de westpunt (Bijlage 8, Figuur 10-4). Wat opvalt is dat in periode 1 , wanneer een groot deel van de plaat nog onder water ligt, het deel midden op de plaat tijdens de suppleties gebruikt wordt door vogels voor en tijdens aanleg van de suppletie (Figuur 6-75). Mogelijk komt dit door de hogere ligging van de suppleties. In periode 2 tijdens de aanleg van de suppletie valt de hoge dichtheid in het zuid-midden van de plaat op, die gedeeltelijk ook over een suppletie valt. Veelgebruikte plekken lijken verder grotendeels hetzelfde.

Ook na de suppletie lijken de meeste vogels nog steeds min of meer dezelfde plekken op de plaat op te zoeken (Figuur 6-76). In periode 1 zitten de vogels iets meer verspreid. In telperiode 2 en 3 zijn dichtheden in de gebieden waar suppleties zijn aangelegd lager en zijn dichtheden hierbuiten, op de veelgebruikte plekken, hoger. Vogels lijken dus dichter op elkaar te foerageren door de gebieden met suppleties te vermijden. In periode 3 zitten op de suppletie in het zuidoosten wel veel vogels. Dit is mogelijk een effect van verkeerd intekenen (pers. comm. tellers DPM).

De verspreiding kan per soort verschillen (Figuur 6-77). De drieteenstrandloper komt relatief veel voor op de westkant van de plaat. Voor de meeste soorten is hetzelfde patroon te zien als voor het totale aantal vogels; na de suppletie lijken de vogels iets dichter op elkaar te zitten waarbij ze de suppleties gedeeltelijk ontwijken. Dit is vooral duidelijk te zien voor de bonte strandloper, scholekster, wulp en zilverplevier. 


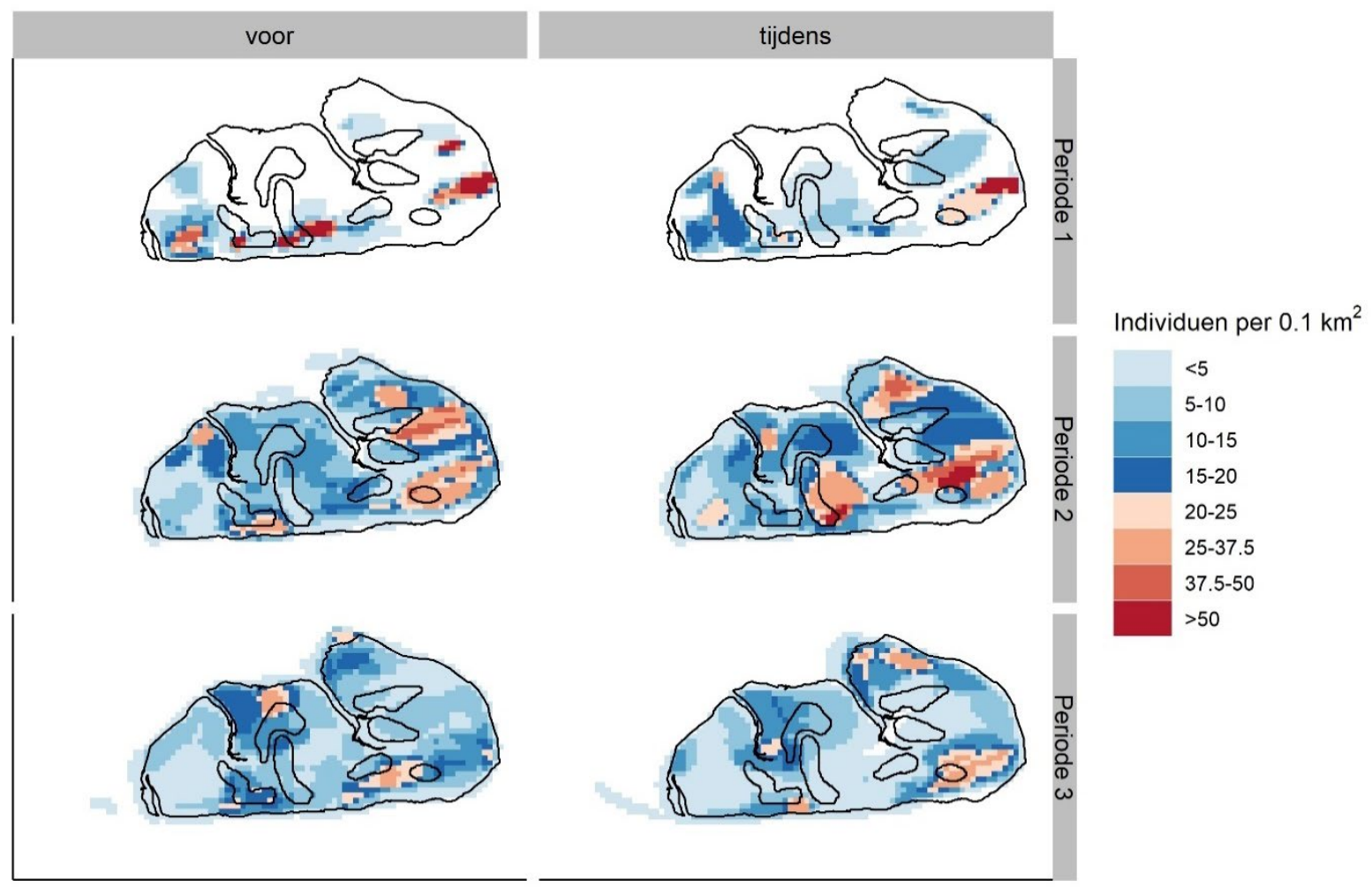

Figuur 6-75 Verspreiding gemiddeld aantal vogels per telperiode over de maanden oktober, november en december voor en tijdens aanleg van de suppleties. De omtrek van de zeven suppleties zijn aangegeven binnen de contouren van de Roggenplaat.
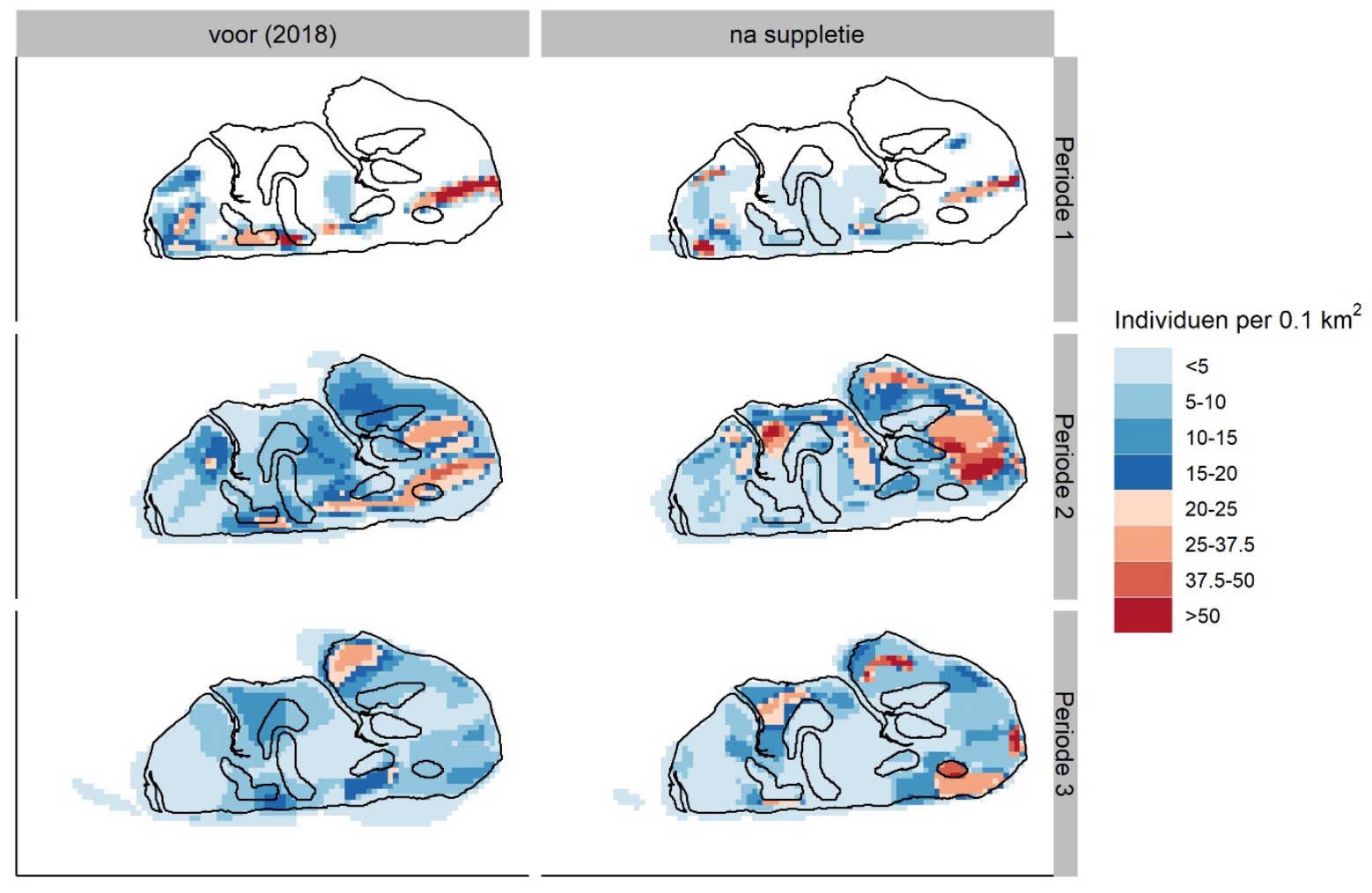

Figuur 6-76 Verspreiding gemiddeld aantal vogels over alle tellingen in 2018 (voor) en in 2020 (na) aanleg van de suppleties. De omtrek van de zeven suppleties zijn aangegeven binnen de contouren van de Roggenplaat. 


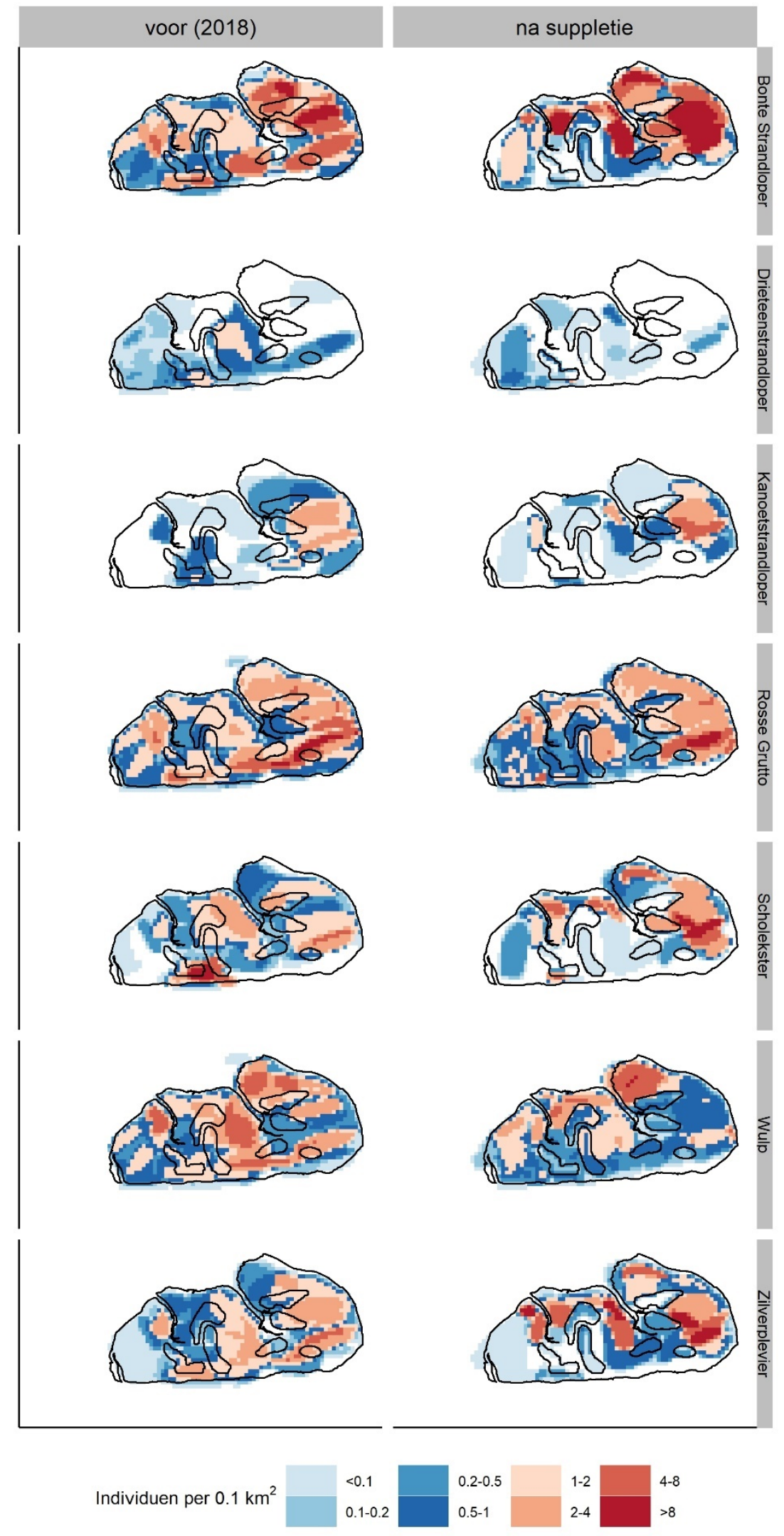

Figuur 6-77 Verspreiding gemiddeld aantal vogels voor een aantal soorten over alle tellingen in 2018 (voor) en in 2020 (na) aanleg van de suppleties in telperiode 2. De omtrek van de zeven suppletie-elementen zijn aangegeven binnen de contouren van de Roggenplaat. 


\subsubsection{Vogelverspreiding in verhouding tot benthosdichtheden}

$\mathrm{Er}$ is een positieve relatie tussen lokale vogeldichtheden per hectare en benthosdichtheid (Figuur 6-78). Dit is het beste te zien in 2020. Deze relatie is alleen in telperiode 2 te zien. In telperiode 1 is enkel een klein deel van de plaat beschikbaar voor vogels, en is een relatie tussen benthos en vogelaantallen dus ook niet te verwachten. In telperiode 3 zitten vogels meer verspreid.

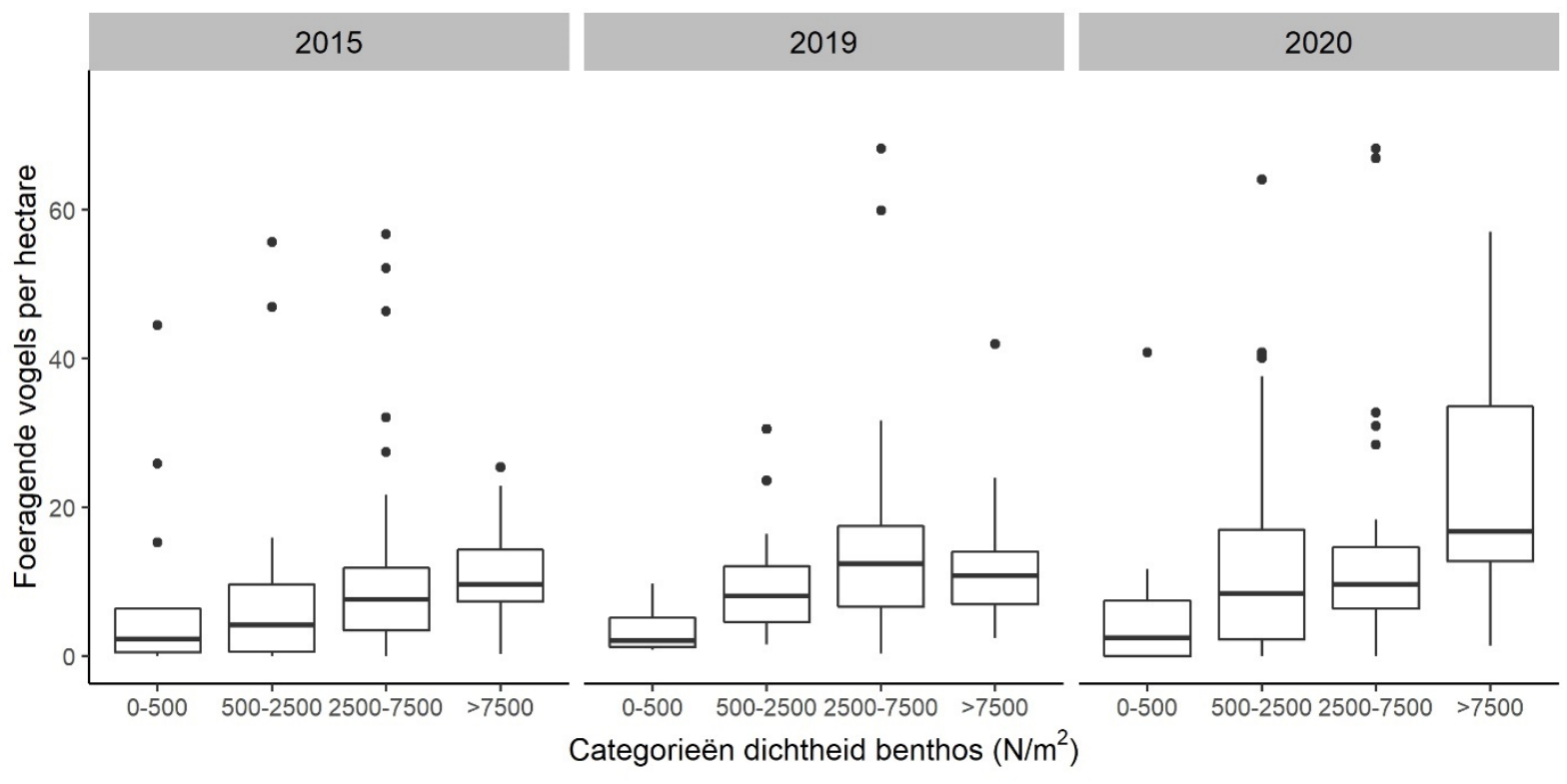

Figuur 6-78 Dichtheid foeragerende vogels in telperiode 2, gemiddeld over de herfst en winter (tellingen oktober-februari) en dichtheden benthos, geordend in vier dichtheidklasses. In 2020 zijn naast de 113 monsterpunten ook nog 72 monsters op de suppleties genomen. De $y$-as is gelimiteerd tot 75 , waardoor een aantal zeer hoge vogeldichtheden niet te zien zijn.

\subsubsection{Resultaten: Gebruik suppleties}

Op de plekken van de suppleties zijn de bodemdieren onder een laag zand bedekt, en bieden hierdoor tijdelijk minder voedsel voor vogels. Het onderzoek naar de Roggenplaat biedt een unieke kans om te bestuderen hoe suppleties gebruikt worden door vogels over de tijd. Tijdens de suppletie zijn de aantallen op de suppleties nog gemiddeld of hoog, na de suppletie zijn de aantallen in de meeste maanden en periodes lager dan eerst. Een uitzondering is oktober na de suppletie, maar in deze maand zijn ook gemiddeld veel vogels op de hele Roggenplaat geteld (Figuur 6-79). Het percentage foeragerende vogels op suppletielocaties is na de aanleg van de suppleties iets lager in alle telperiodes (Figuur 6-80). 

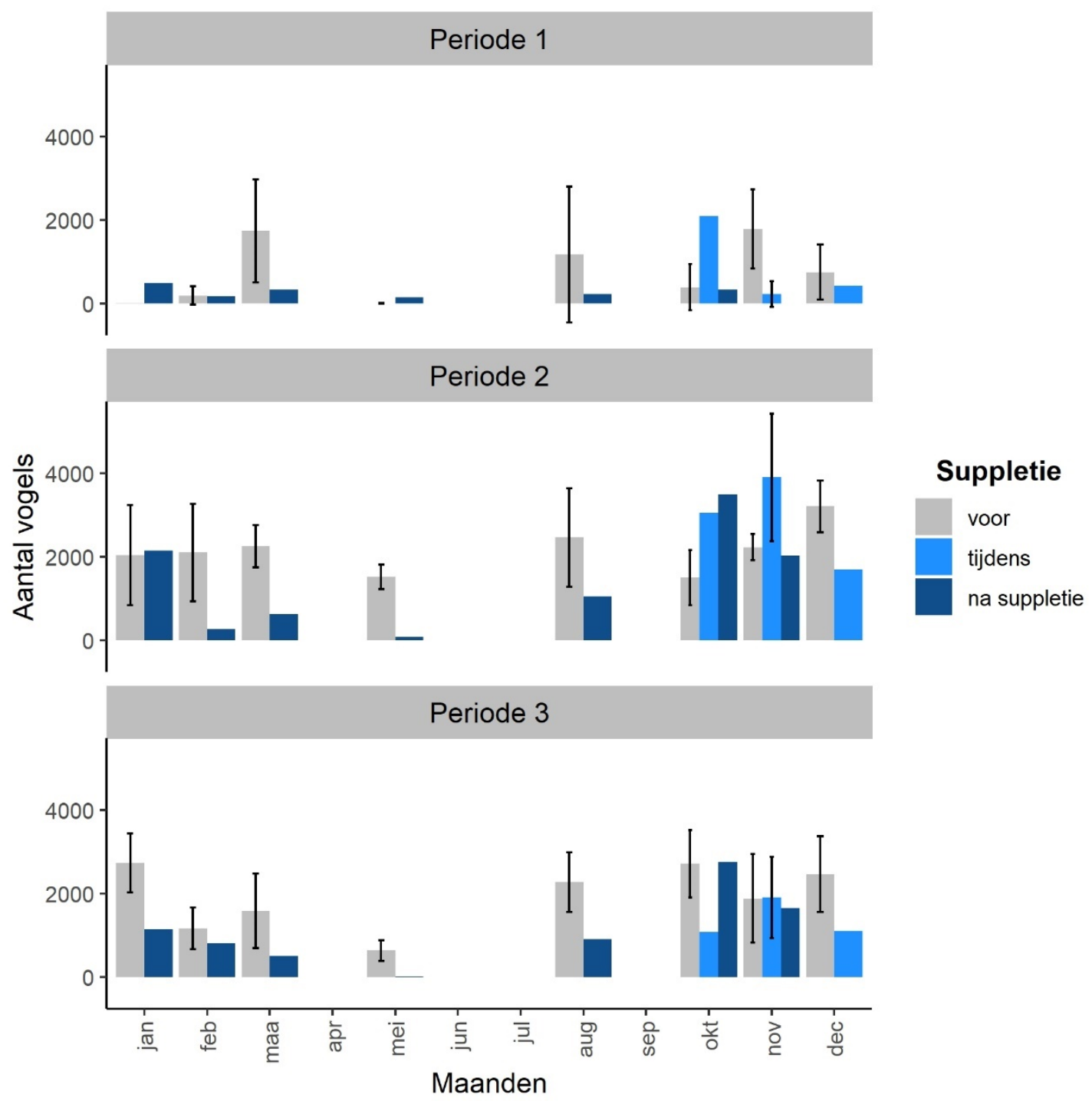

Figuur 6-79 Aantal vogels per maand voor tijdens en na de suppleties op de suppletie locaties. Tussen 2015 en 2019 (voor aanleg van de suppleties) is in oktober twee keer geteld, in de andere maanden drie of vier keer. In maart 2017 is er tweemaal geteld en in november 2019 tweemaal (tijdens de aanleg van de suppleties).

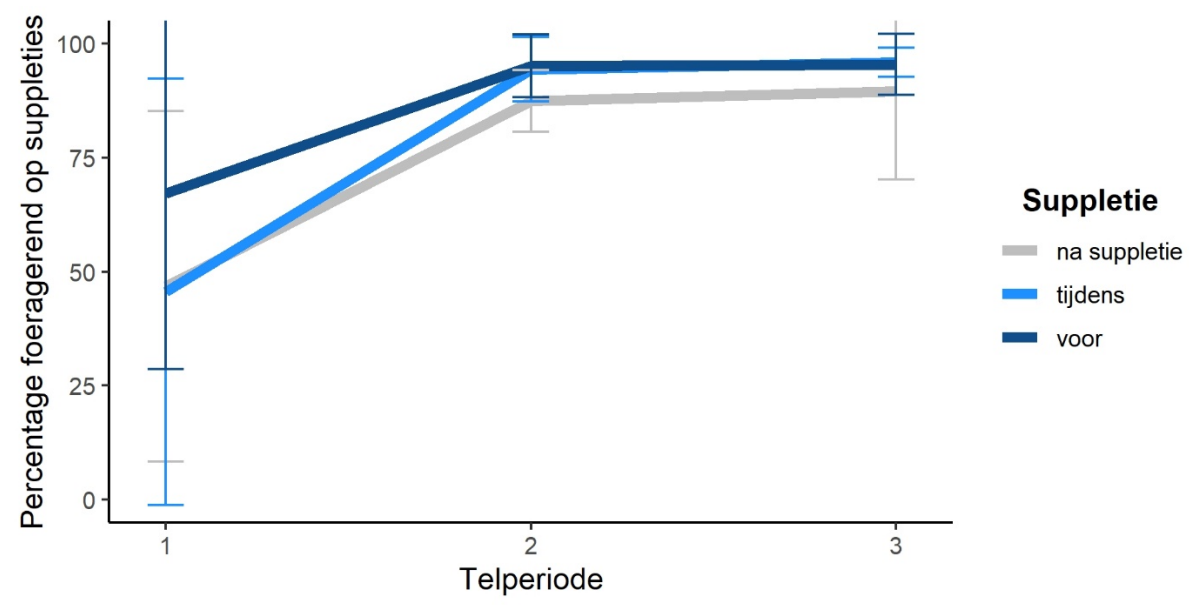

Figuur 6-80 Percentage foeragerende vogels op suppleties voor, tijdens en na suppleties. 
Wanneer we kijken naar de soortsamenstelling op de suppleties van veelvoorkomende soorten, valt op dat tijdens de aanleg een grote groep zilvermeeuwen is geteld (periode 2, oktober) (Figuur 6-81). Deze soort komt mogelijk af op dode organismen die vaak te vinden zijn in suppletiezand. In oktober en november na de suppleties zijn de aantallen vogels weer vergelijkbaar met voor de suppleties in periode 2 en 3, maar de soortsamenstelling wijkt in oktober af. In periode 2 is een grote groep kokmeeuwen gezien en in periode 3 relatief veel rosse grutto's.

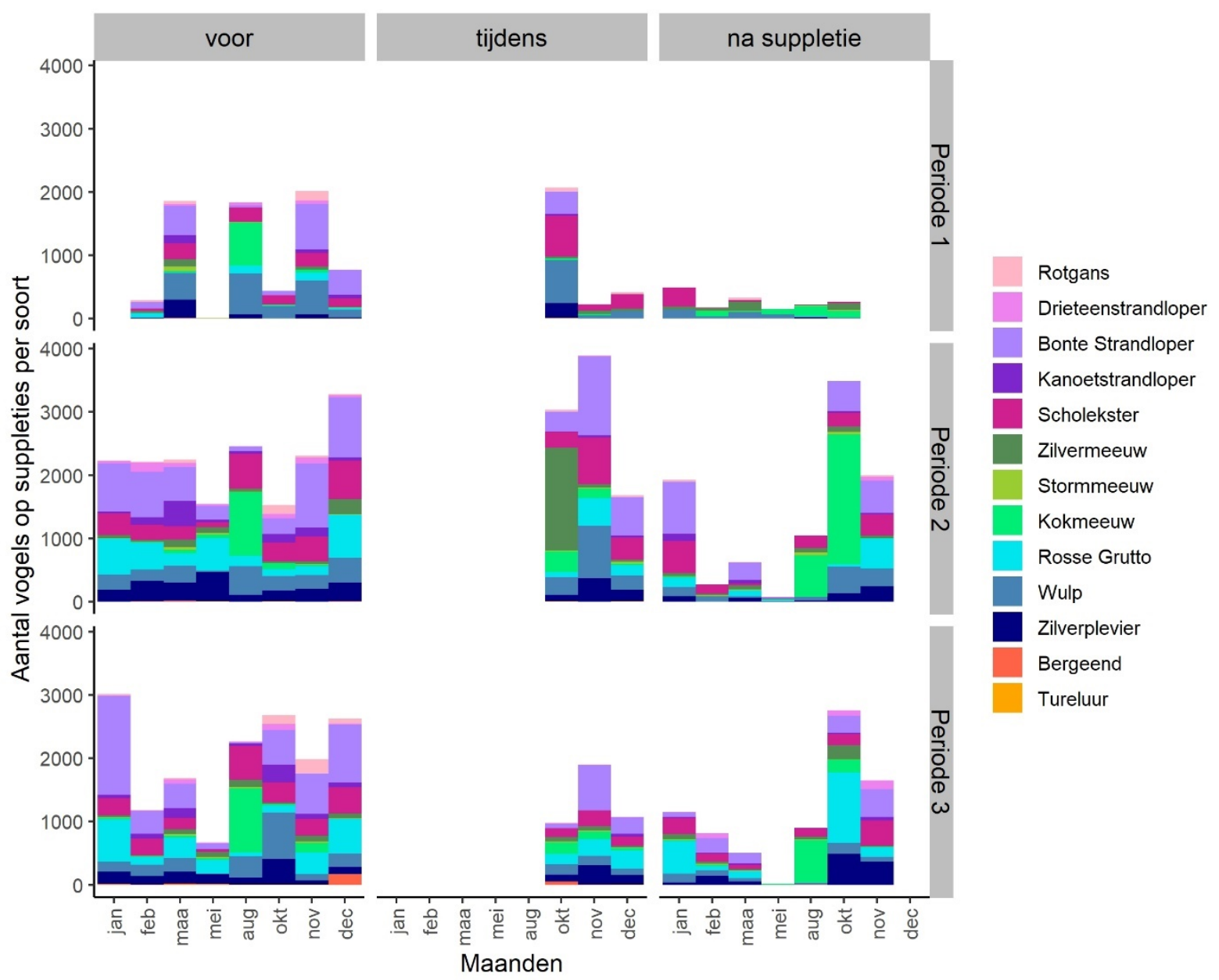

Figuur 6-81 Aantal vogels per maand voor tijdens en na de suppleties in de gebieden van de suppleties voor de 13 meest voorkomende soorten. Tussen 2015 en 2019 (voor aanleg van de suppleties) is in oktober twee keer geteld, in de andere maanden drie of vier keer. In maart 2017 is er tweemaal geteld en in november 2019 tweemaal (tijdens de aanleg van de suppleties).

\subsubsection{Zeehondentellingen}

\subsubsection{Methode}

Om te onderzoeken hoe de zeehondenpopulatie zich op de Roggenplaat ontwikkelt t.o.v. de trends in de gehele Oosterschelde en Delta is gebruik gemaakt van MWTL maandelijkse (vliegtuig)zeehondentellingen (opgenomen in het biologisch monitoring programma van de Zoute Rijkswateren) vanaf 2015, zie Walles et al. (2021). In april en december 2020 is er niet gevlogen boven de Oosterschelde i.v.m. corona. 


\subsubsection{Resultaten: Zeehonden in de Zeeuwse wateren}

Sinds 2015 nemen de gewone en grijze zeehond in aantallen toe in de Zeeuwse wateren (Figuur 6-82). Het aantal gewone zeehonden is tussen 2019 en 2020 langzaam gestegen ten opzichte van het jaar ervoor. De Voordelta is het belangrijkste gebied voor zowel de gewone als de grijze zeehond (Figuur 6-83). Van beide soorten is de trend hier positief.

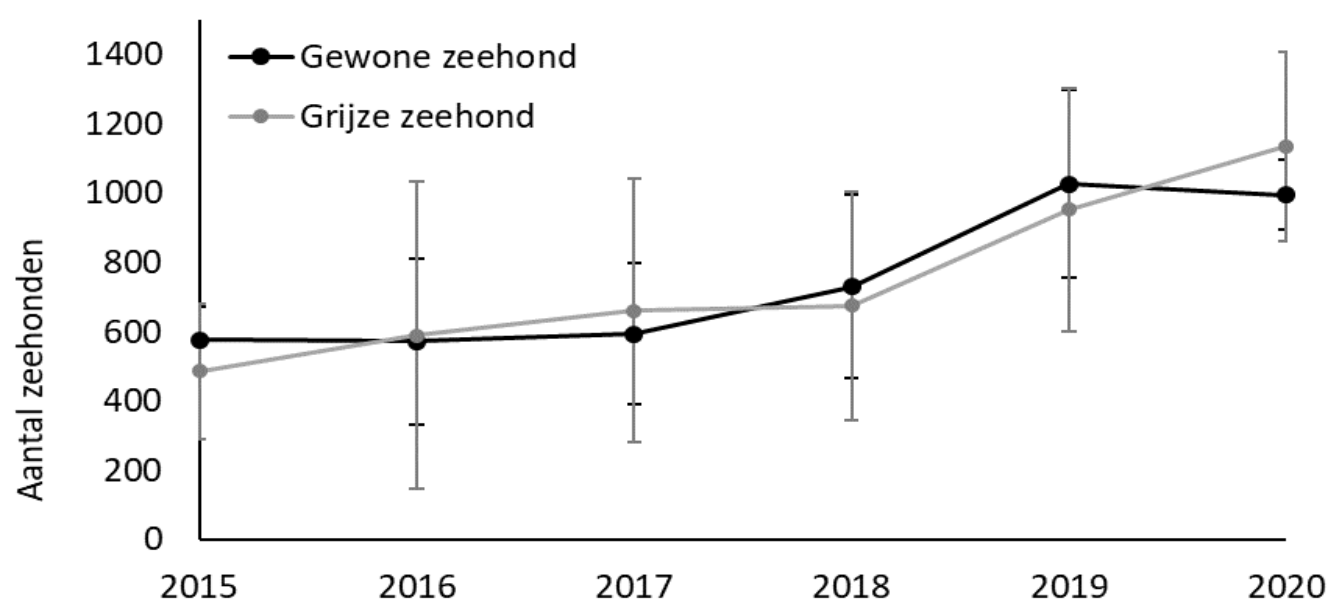

Figuur 6-82 Trend van het jaargemiddelde van zeehonden in Zeeuwse wateren tussen 2015 en 2020. De waarden (gemiddelde \pm standaarddeviatie) zijn gebaseerd op jaarlijkse gemiddelden van maandelijkse tellingen vanuit het vliegtuig en vanaf de boot (Grevelingenmeer).
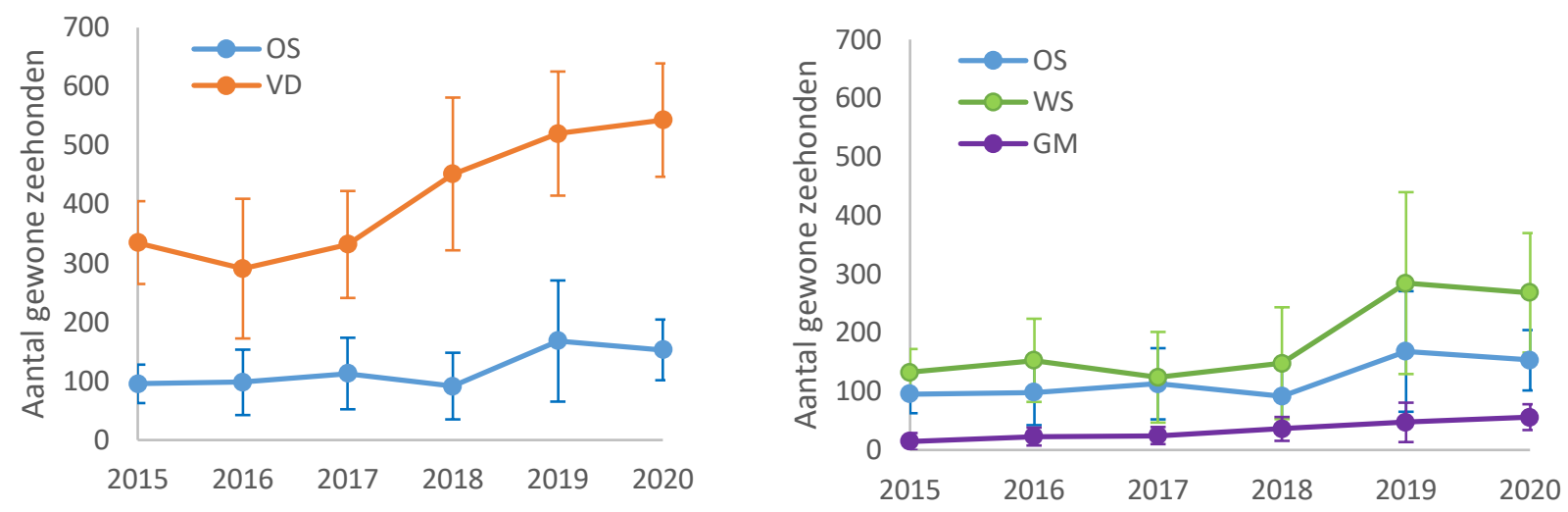

Figuur 6-83 Trend van het jaargemiddelde van de gewone zeehond per gebied tussen 2015 en 2020. De waarden (gemiddelde \pm standaarddeviatie) zijn gebaseerd op jaarlijkse gemiddelden van maandelijkse tellingen vanuit het vliegtuig en vanaf de boot (Grevelingenmeer). OS: Oosterschelde, VD: Voordelta, WS: Westerschelde, GM: Grevelingenmeer.

\subsubsection{Resultaten: zeehonden op de Roggenplaat en op andere platen in de Oosterschelde sinds 2015}

Met name het Middengeultje en de Westgeul zijn belangrijke rustgebieden voor zeehonden op de Roggenplaat en in de Oosterschelde. In het Middengeultje en de Westgeul zijn de aantallen van de Gewone Zeehonden stabiel gebleven tussen 2015 en 2018. Na 2018 lijken de aantallen iets te stijgen (Figuur 6-84). De grijze zeehond is sinds 2017 verdwenen uit het Middengeultje en in de Westgeul sinds 2018. In september 2020 is echter weer één enkele grijze zeehond gespot in de Westgeul. 


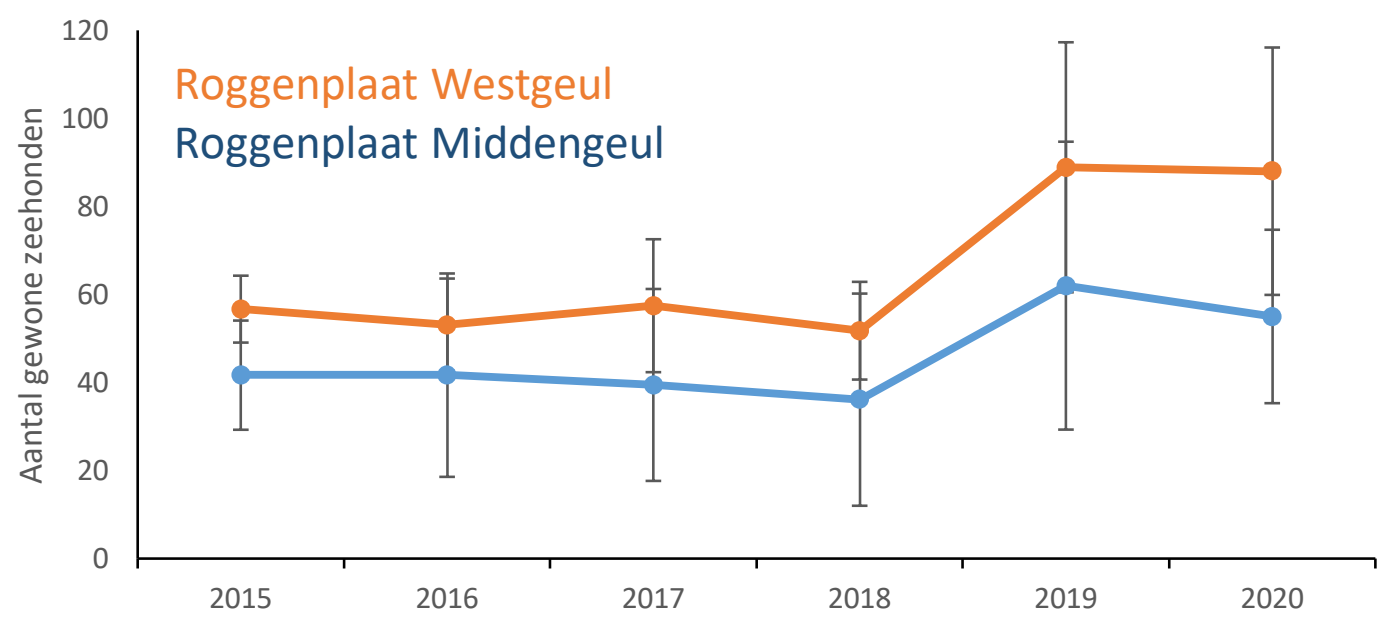

Figuur 6-84 Trend van het jaargemiddelde van de gewone zeehond op de twee belangrijkste plaatsen op de Roggenplaat. De waarden (gemiddelde \pm standaarddeviatie) zijn gebaseerd op jaarlijkse gemiddelden van maandelijkse tellingen vanuit het vliegtuig.

\subsubsection{Resultaten: aantallen voor en na aanleg van de suppleties}

De maandelijkse gewone zeehond aantallen in de Westgeul verschillen niet voor en na aanleg van de suppleties (Figuur 6-85). Het seizoensverloop in 2019 is vergelijkbaar met dat in 2020. In het Middengeultje, zijn er relatief grotere verschillen tussen 2019 en 2020 met hogere aantallen in januari, juli en augustus 2020 en lagere aantallen in februari, maart en september (Figuur 6-86). Deze schommelingen zien we ook terug in de Voordelta aantallen (Figuur 6-87). Het ontbreken van tellingen voor de april 2020 en voor september-december (niet gevlogen vanwege corona) laat geen precieze trend analyse toe. Hierdoor kan de impact van de zandsuppletie op korte termijn niet worden vastgesteld.

De gewone zeehond baart haar jongen in de zomer. In de Westgeul zijn in 2019, 27 pups in juli en 9 pups in augustus waargenomen en in 202023 pups in juni. In het Middengeultje zijn in juli en augustus van 2019, respectievelijk 18 en 10 pups waargenomen. In 2020 zijn geen pups waargenomen in deze geul.

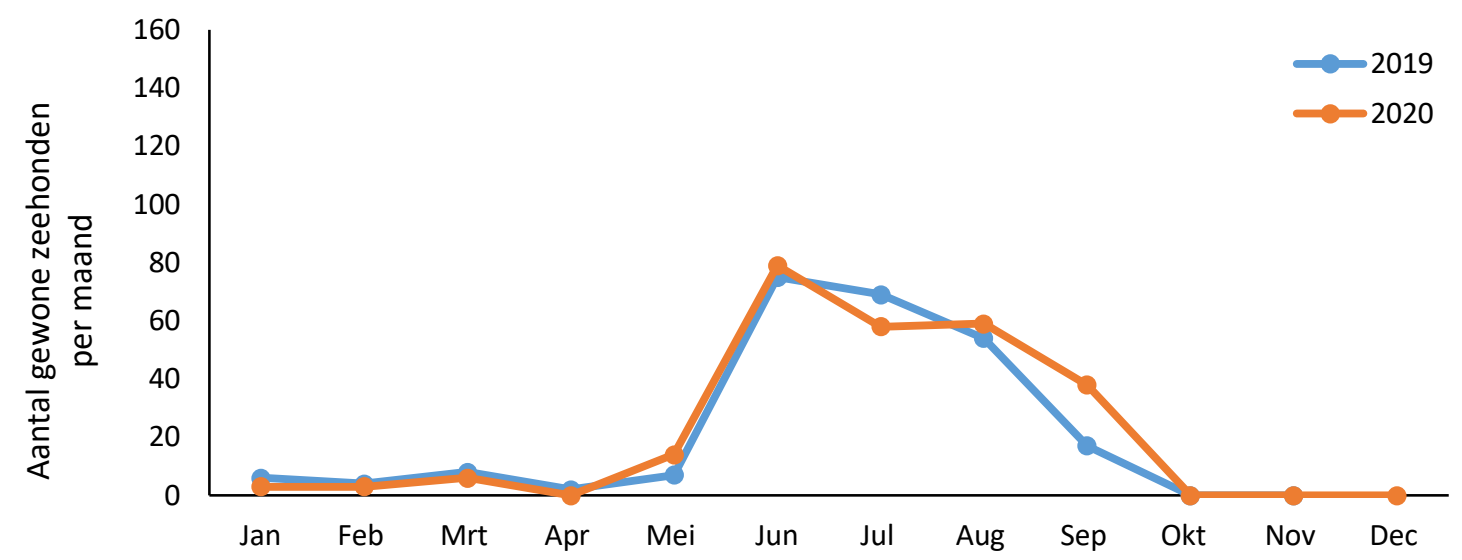

Figuur 6-85 Maandelijkse aantallen gewone zeehonden in de Westgeul voor en na aanleg van de suppleties. 


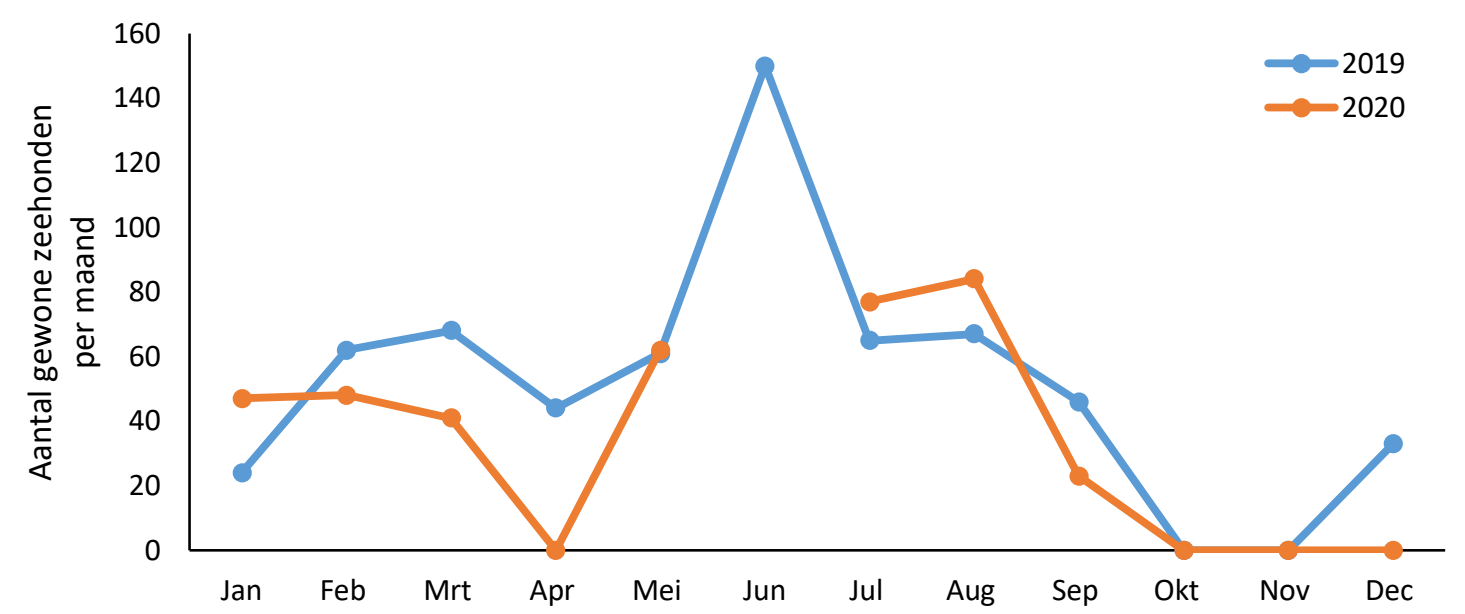

Figuur 6-86 Maandelijkse aantallen gewone zeehonden in het Middengeultje voor en na aanleg van de suppleties.

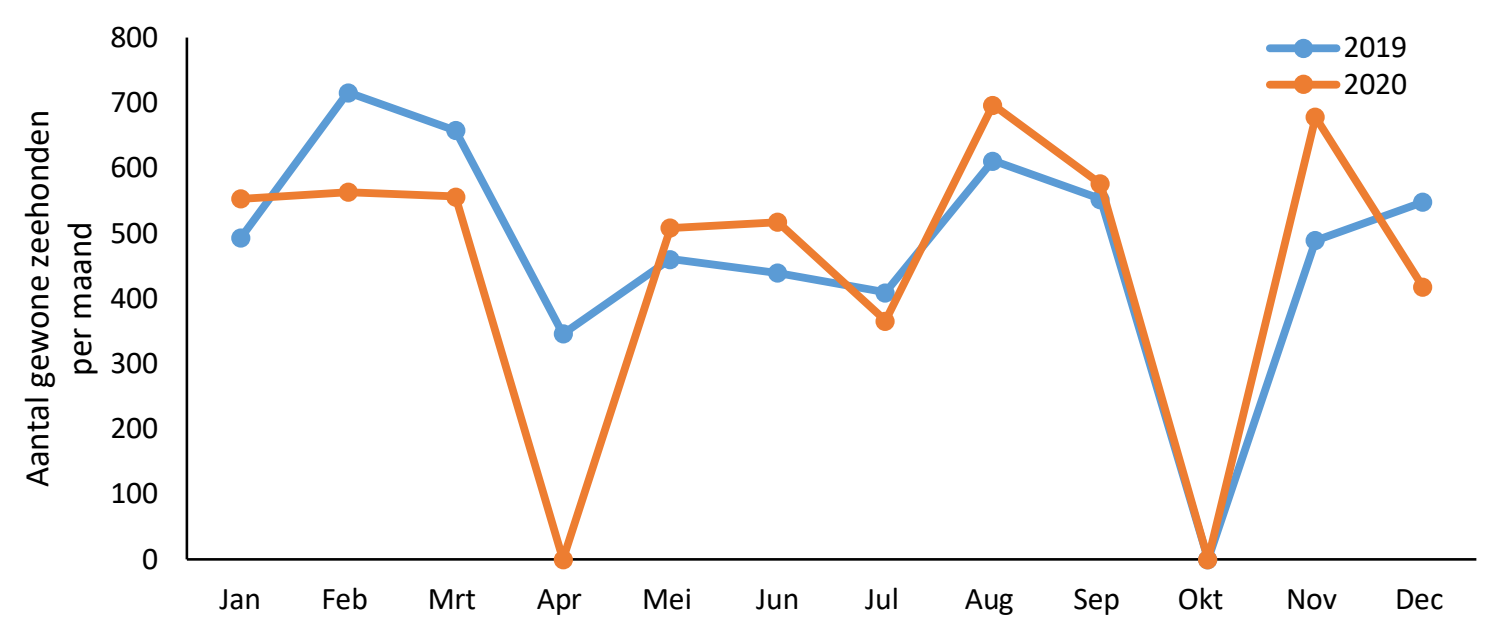

Figuur 6-87 Maandelijkse aantallen gewone zeehonden in de Voordelta. 


\section{$7 \quad$ Waterbeweging en -kwaliteit van het Middengeultje en nabij mosselpercelen}

\subsection{Doel}

Het Middengeultje is een belangrijke afvoergeul voor het water en mogelijk ook voor benthische diatomeeën vanaf de Roggenplaat tijdens de ebfase (Van der Werf e.a., 2016). Het Middengeultje mondt uit in de Hammen en stroomt daarbij over een aantal kweekpercelen (Figuur 7-1). Het is mogelijk dat deze geul een belangrijke rol speelt in de voedselaanvoer voor de mosselen op deze percelen, in het bijzonder de percelen Hammen 68C, 68D, 69, 70 en 71. Verandering in de morfologie van de geul (aanzanding/erosie of verlegging) kan gevolgen hebben voor de volumetransporten en daarmee de voedselaanvoer naar de percelen. Ook de verandering in concentraties slib en chlorofyl in het Middengeultje kan effect hebben op de voedselaanvoer en daarmee de productie op de percelen beïnvloeden. Als de benthische diatomeeën van de plaat een belangrijk onderdeel vormen van het voedsel van de mosselen in de monding van het Middengeultje zou een verandering in benthische primaire productie op de plaat als gevolg van de suppletie ook effect kunnen hebben voor de mosselen op de betreffende percelen.

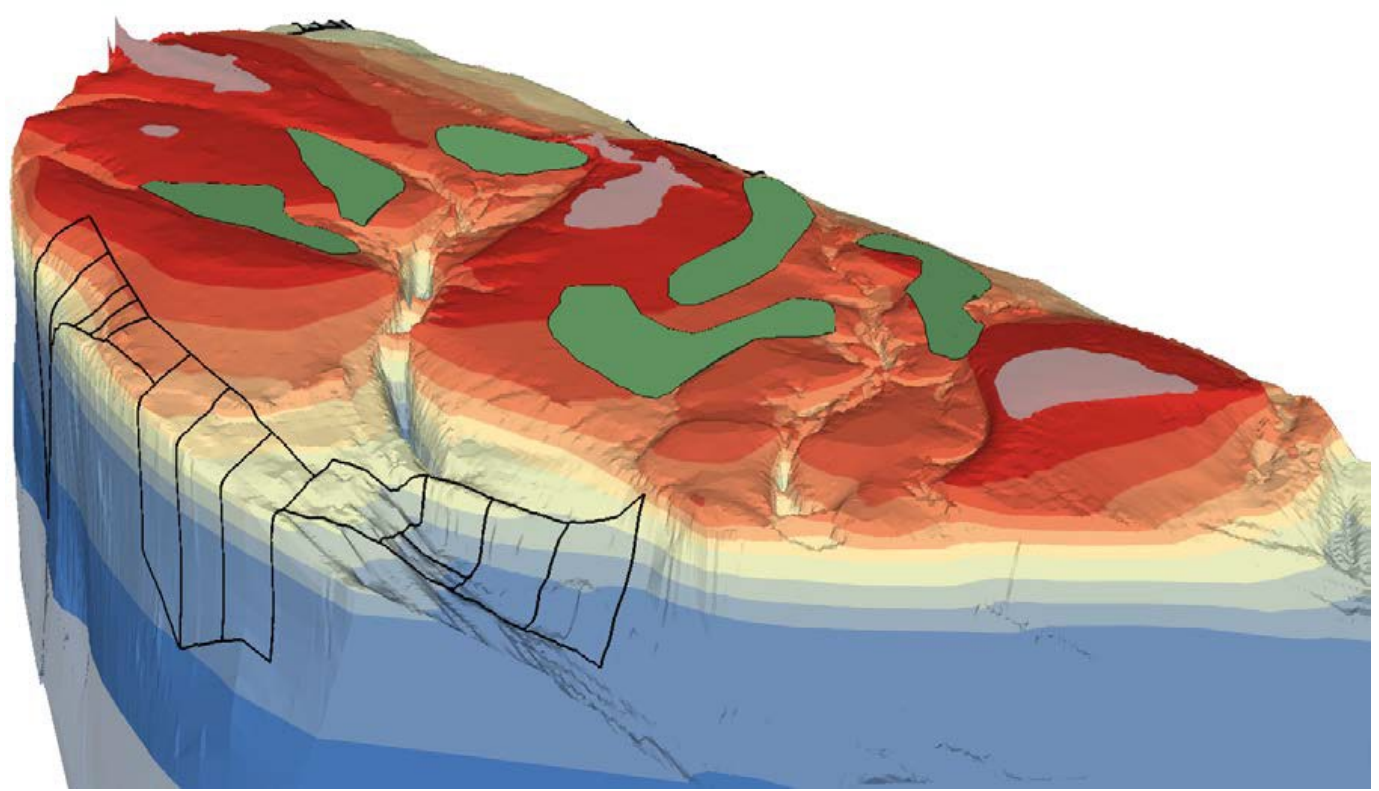

Figuur 7-1. 3D overzicht van de Roggenplaat gezien vanuit het noordwesten. Te zien zijn de monding van het Middengeultje en het Westgeultje. De suppleties zijn ingetekend in het groen. De ligging van de kweekpercelen aan de noordkant zijn ingetekend door middel van zwarte lijnen. Door de oriëntatie van het plaatje en het vergroten van de hoogte verschillen, lijken de percelen steiler af te lopen dan in werkelijkheid.

Om het belang van het Middelgeultje voor de voedselaanvoer (in het bijzonder gesuspendeerde benthische diatomeeën) naar de nabijgelegen kweekpercelen te onderzoeken zijn veranderingen in morfologie (zie hoofdstuk 6), debieten, concentraties 
algen en zwevend stof en het aandeel benthische diatomeeën onderzocht. Tot slot is ook een aanvullende meting met een sensorboot uitgevoerd door de Hogeschool Zeeland voor ruimtelijke patronen in zwevendstof en chlorofyl. Met deze metingen kan onderzocht worden of de aanleg van de suppleties effect hebben op de voedselaanvoer door het Middengeultje naar de percelen.

\subsection{Turbiditeit en chlorofyl}

\subsubsection{Methode}

Voedselaanvoer vanuit het Middengeultje is onderzocht door middel van continue sliben chlorofylmetingen. Op drie locaties in de geul zijn in januari 2019 meetpalen geplaatst voorzien van onder andere een turbiditeitsmeter en chlorofylmeter die continue metingen uitvoeren op één meter van de bodem (Figuur 7-2). Als referentie is er tegelijkertijd een meetpaal geplaatst in de Hammengeul buiten de directe invloed van het Middengeultje. De analyse van deze data richt zich op het verschil in concentraties tussen de eb- en de vloedstroom voor de situatie vóór en na de aanleg van de suppleties. Om een indicatie te krijgen van de dynamica van het system is er zowel naar de langetermijn trends als de korte termijn trends gekeken. De lange termijn trends geven inzicht in de fluctuaties door het jaar heen en seizoenseffecten (algenbloei), terwijl korte termijn trends inzicht geven over variatie binnen een getijdecyclus. Alvorens deze lange termijn meetreeks gebruikt kon worden voor analyse moest de data op een consistente manier opgeschoond worden van ruis en eventuele foutieve metingen, zie Bijlage 9.

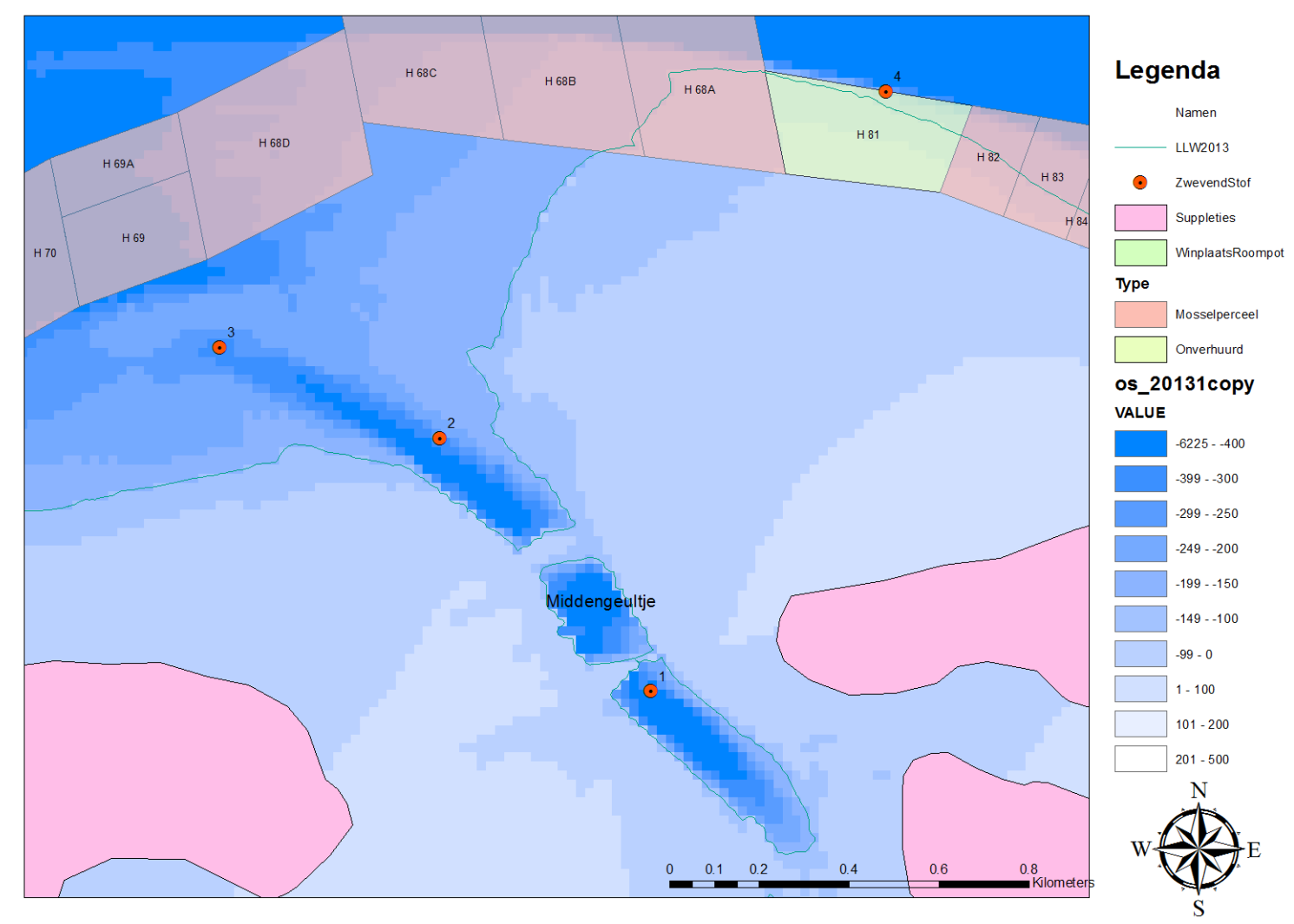

Figuur 7-2. Positie van de vier vaste meetstations nabij het Middengeultje en de mosselpercelen. $\mathrm{Nr} 4$ is de meetpaal in de Hammen. 


\subsubsection{Resultaten: Lange termijn}

De meetgegevens verkregen uit de sensoren laten een piek tijdens de lentebloei zien in zowel de concentratie zwevend stof (turbiditeit) als chlorofyl.(Figuur 7-3). Verder komen er tijdens de zomermaanden, juli en augustus veel extreme waarden voor. Dit komt waarschijnlijk door de piek van zeesla in deze maanden. $\mathrm{Na}$ aanleg van de suppleties zien we wederom een piek tijdens de lentebloei. Het is niet mogelijk om lange termijn trends te vergelijken voor en na aanleg van de suppleties. Echter is er visueel geen verschil te zien tussen de hoogte, duur en timing van de hoge chlorofyl metingen tijdens de lentebloei.

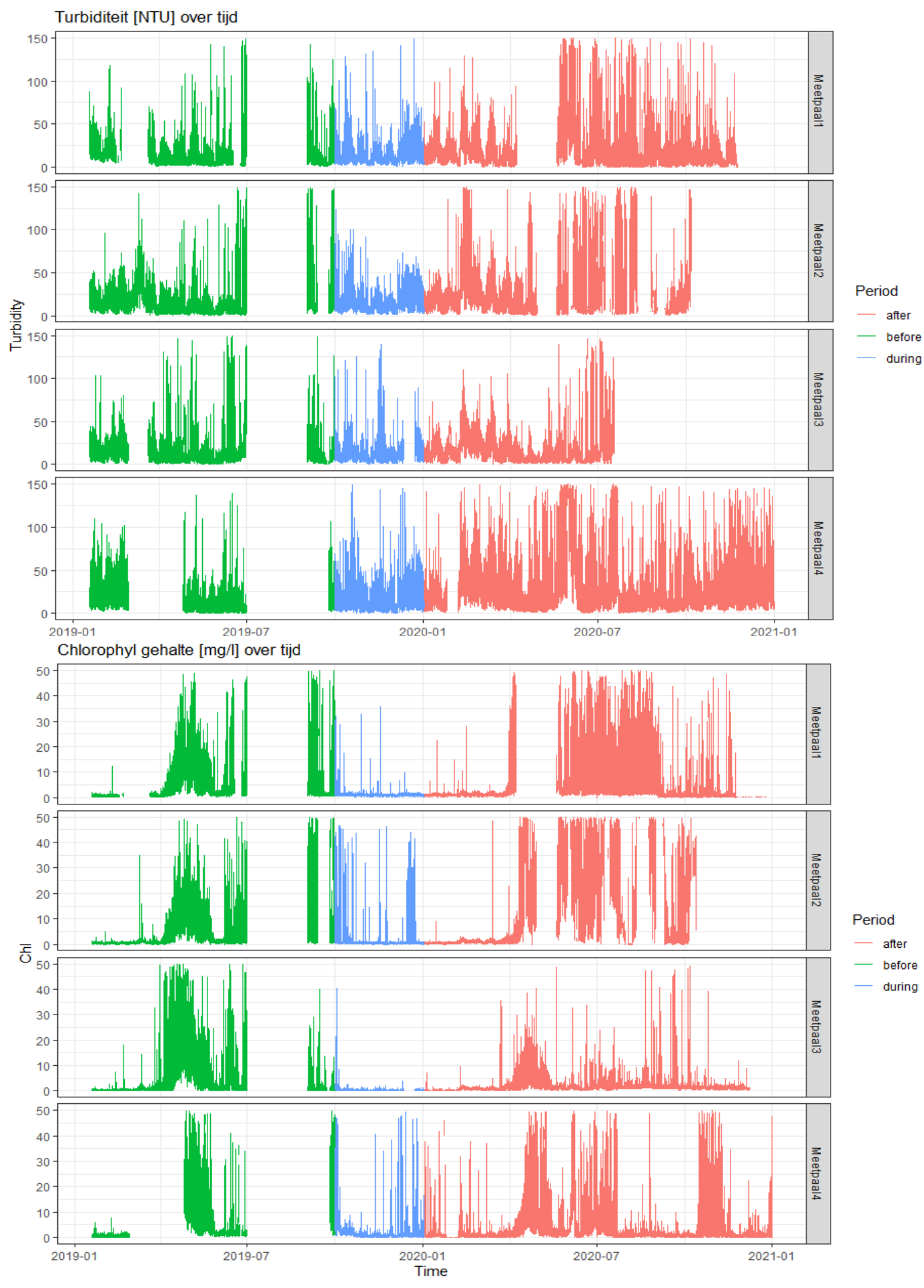

Figuur 7-3 Verloop turbiditeit en chlorofyl over de periode januari 2019 tot en met december 2020 voor alle meetpalen. Een duidelijke lentebloei en veel extreem hoge waarden tijdens de piek in zeesla is zichtbaar. 


\subsubsection{Resultaten: Korte termijn}

Turbiditeit en chlorofyl laten op dagniveau (januari 2019) een duidelijk patroon zien, waarbij beide parameters pieken in het Middengeultje (meetpalen 1, 2 en 3) net voor hoog water, en in de Hammen (meetpaal 4) net na hoog water (Figuur 7-4). Ondanks dat frequente foutieve metingen door de meetpalen nauwkeurige vergelijkingen lastig maken is dit over het algemeen het patroon dat door heel het jaar heen werd geobserveerd. Doordat er bij meetpaal 4 al een afwijkend patroon voor aanleg van de suppleties is geobserveerd, doet dit vermoeden dat dit referentiepunt slecht gekozen is.

$\mathrm{Na}$ aanleg van de suppletie, lijkt het verloop op dagniveau (januari 2020), vergelijkbaar (Figuur 7-5). De hoogtes van de gemeten waarden verschillen enigszins, tussen T0 en T1, echter laat de figuur hierin een momentopname zien. Enige afwijkingen betreffen meetpaal 3, waarbij een groot deel van november 2020 pieken werden geobserveerd na hoog water in plaats van ervoor (en daarbij eenzelfde patroon volgt als meetpaal 4). Het is niet duidelijk wat hiervan de exacte oorzaak is aangezien er eerder in het jaar nog wel pieken voor hoog water voorkwamen bij meetpaal 3. Een mogelijkheid is dat weersomstandigheden meespeelden. Een andere afwijking betreft meetpaal 4, in de laatste twee weken van oktober 2020, waarbij opvallend hoge waarden aan chlorofyl geobserveerd werden (Figuur 7-3). Het patroon is hierbij nog aanwezig, wat indiceert dat het geen zeesla of een foute meting betref, waarbij piekconcentraties aan algen rond $60 \mathrm{mg} / \mathrm{l}$ voorkomen.

\subsubsection{Resultaten: Relatie met getij}

Om te onderzoeken of deze patronen consistent zijn over een langere periode, zijn turbiditeit en chlorofyl ten opzichte van het moment in het getij uitgezet. Hierbij zijn afwijkende perioden en waarden eerst verwijderd (zie Bijlage 9). Deze analyse laat zien dat er inderdaad een vast patroon binnen de getijdencyclus optreedt. De situatie voor aanleg is vervolgens vergeleken met de situatie na de aanleg van de suppleties. Hierbij zijn voor de TO situatie de data uit de periode van 19 januari 2019 tot 1 oktober 2019 meegenomen, en voor de T1 situatie de data tussen 1 januari 2020 en 31 december 2020. Er zijn geen opvallende verschillen te zien binnen de getijdencyclus voor en na aanleg van de suppleties (Figuur 7-6).

Dat chlorofyl en zwevend stof net voor hoog water pieken in het Middengeultje, kan mogelijk verklaard worden door het wegspoelen van geaccumuleerde deeltjes op de plaat. Het gedeelte van de plaat dat vlak voor de hoge metingen onder water ligt, waar vermoedelijk de algen van afkomstig zijn, wordt weergeven in Figuur 7-7. Een uur voor hoog water kentert het getij in het Middengeultje, hierbij neemt de stroomsnelheid af, zie Figuur 7-7. Dit is rond het moment waarop meetpaal 1, 2 en 3 de hoogste concentraties aan chlorofyl meten. De stroomsnelheid neemt vlak voor hoogwater weer toe en keert vervolgens richting het noordwesten. In deze periode neemt de chlorofylconcentratie af. Bij meetpaal 4 vindt de piek in chlorofyl en turbiditeit later plaats, namelijk net na hoog water. Het vermoeden is dat, tijdens de periode net voor hoogwater, het water lang genoeg stilstaat in het Middengeultje, zodat algen kunnen bezinken en hoge concentraties gemeten kunnen worden nabij de bodem. Zodra het water kentert en de andere kant op stroomt, worden deze algen dan ook weer weggespoeld en gemeten bij meetpaal 4. 
Mogelijke draagt afwatering van de plaat door het Middengeultje bij aan de voedselaanvoer richting de percelen. Vanuit het Middengeultje zien we een verhoogde concentratie voedsel (chlorofyl) net voor hoogwater. Rond de kentering komt het water tijdelijk stil te staan en kunnen algen neerslaan. De verhoogde algenconcentratie die net voor de kentering richting de percelen stroomt zou voedseltoelevering voor de mosselpercelen in de monding van de geul kunnen betekenen.
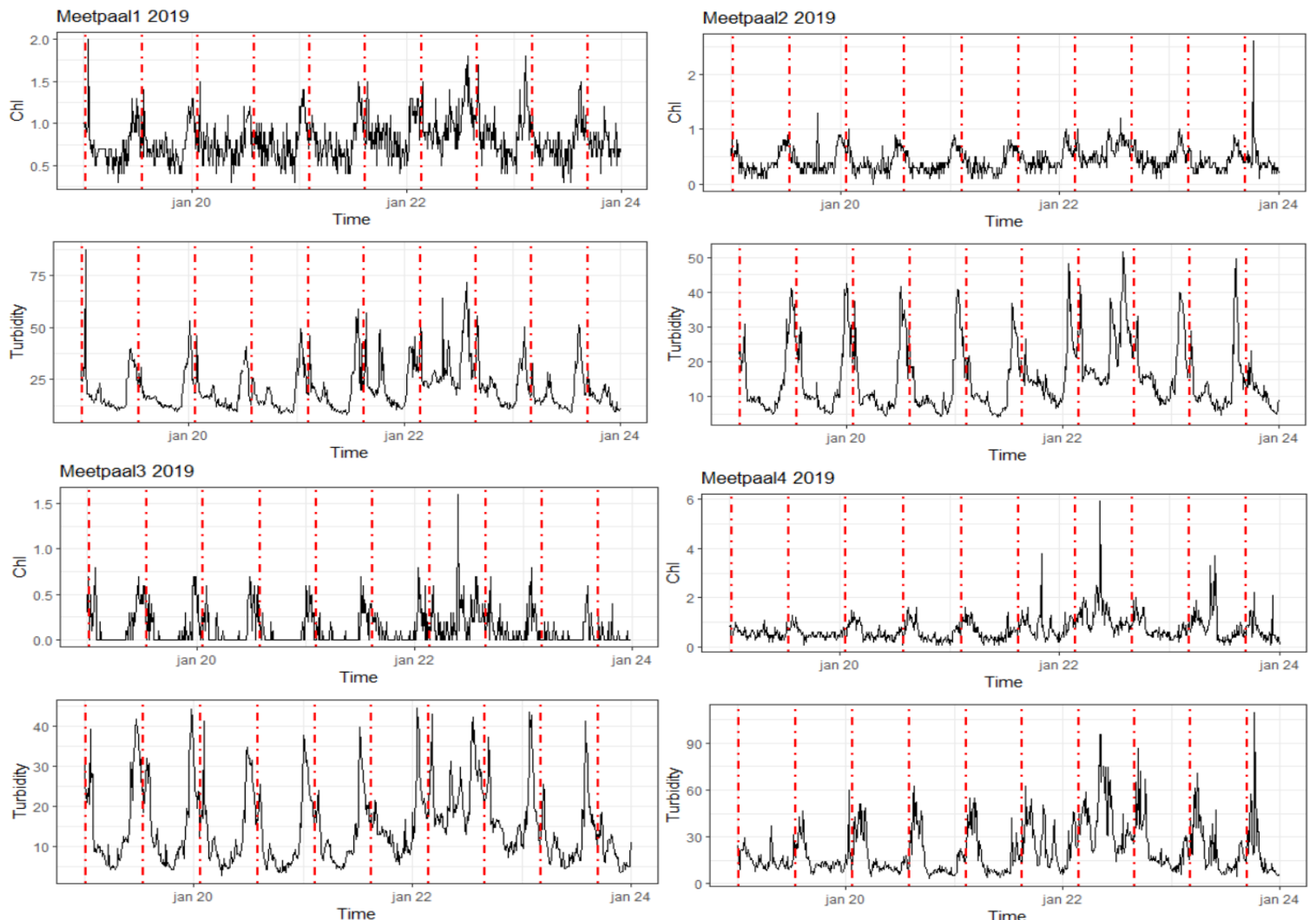

Figuur 7-4 Dagelijks verloop van chlorofyl en turbiditeit over een korte periode van alle meetpalen in 2019 , rode stippellijnen geven het tijdstip van hoogwater aan.
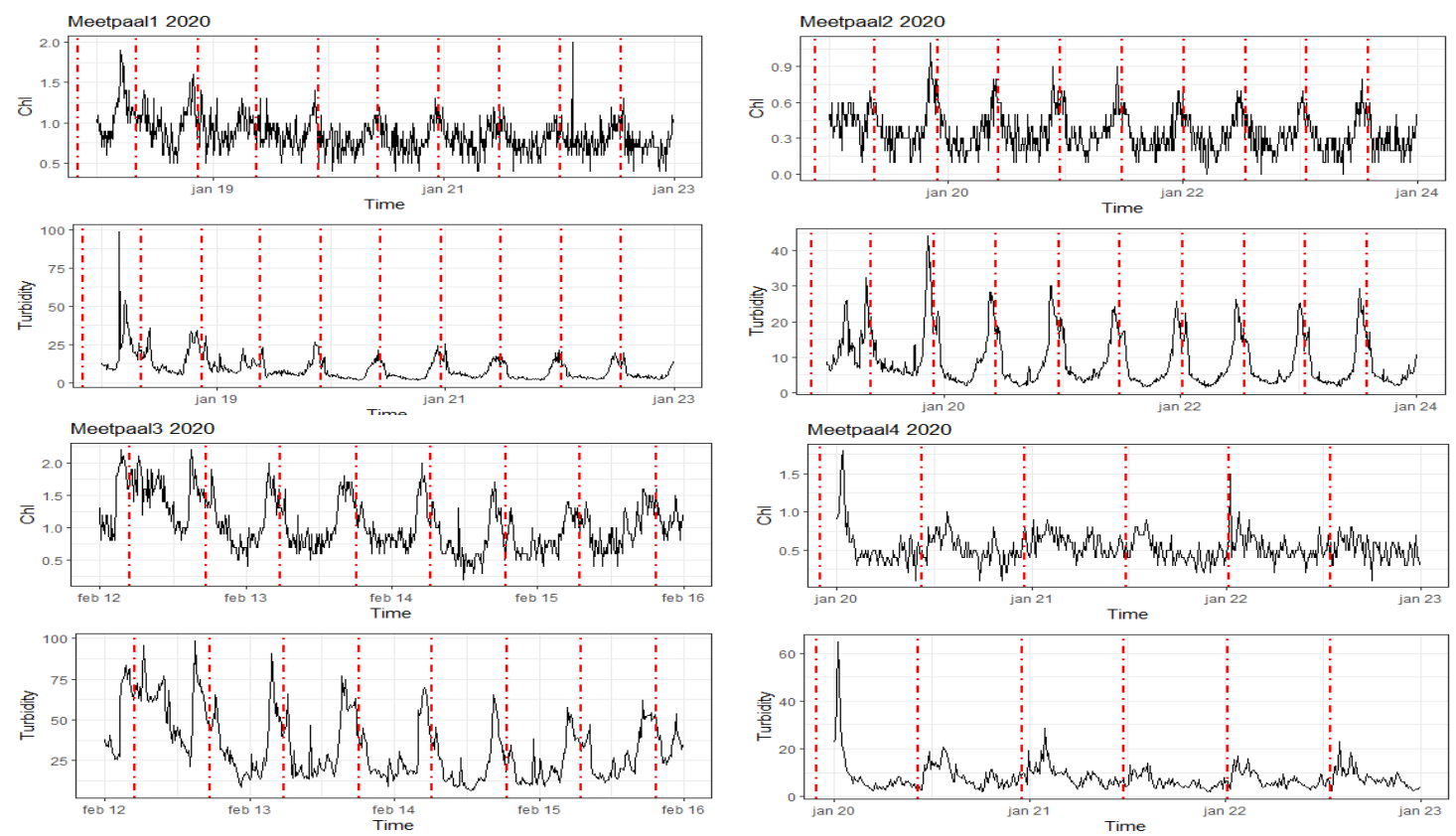

Figuur 7-5 Dagelijks verloop van chlorofyl en turbiditeit over een korte periode van alle meetpalen in 2020 , rode stippellijnen geven het tijdstip van hoogwater aan. Voor meetpaal 3 is een afwijkende periode gevisualiseerd, doordat er tussen 01-11-2019 en 06-022020 veel negatieve waarden gemeten zijn (zie Bijlage 9). 

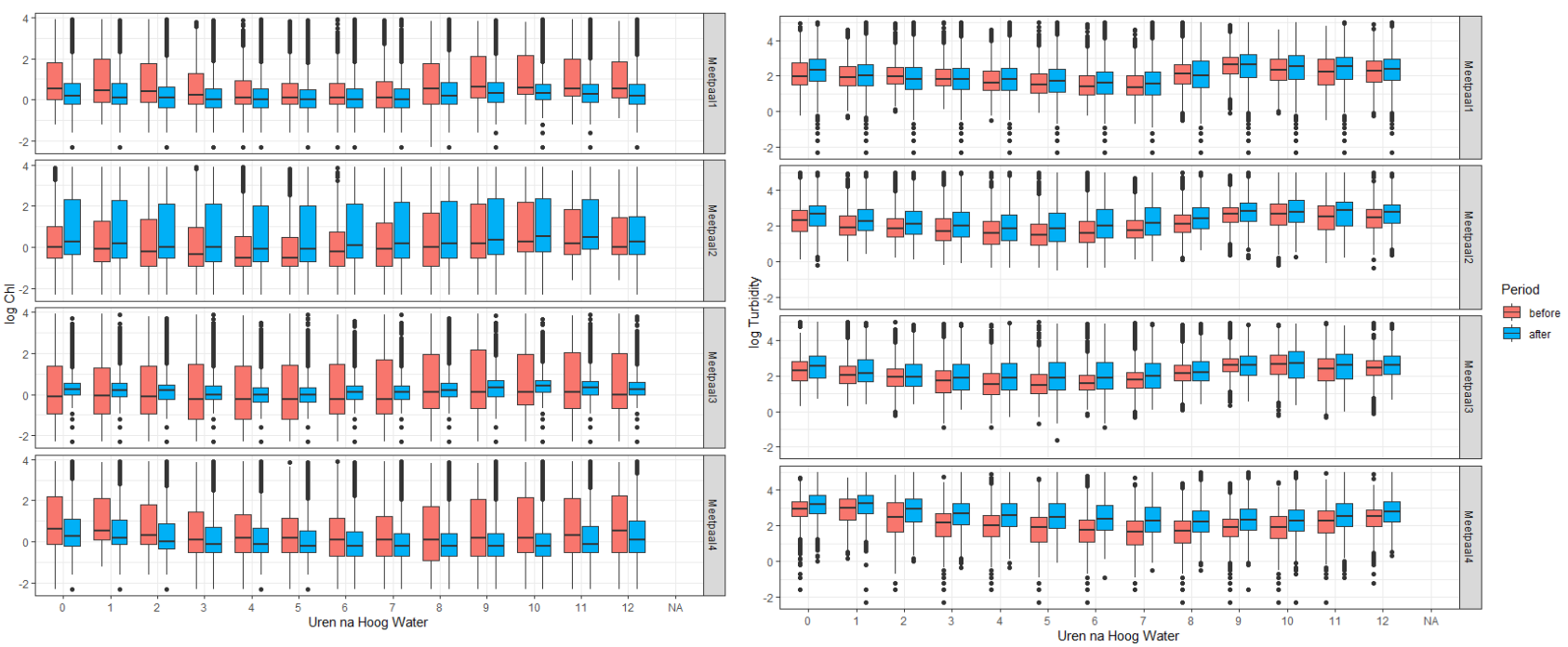

Figuur 7-6 Gemiddelde gemeten chlorofyl (log mg/l) en turbiditeit (log NTU) waarden ten opzichte van uren na het laatst gemeten hoogwater moment. Uitschieters zijn voor het maken van deze grafiek verwijderd.
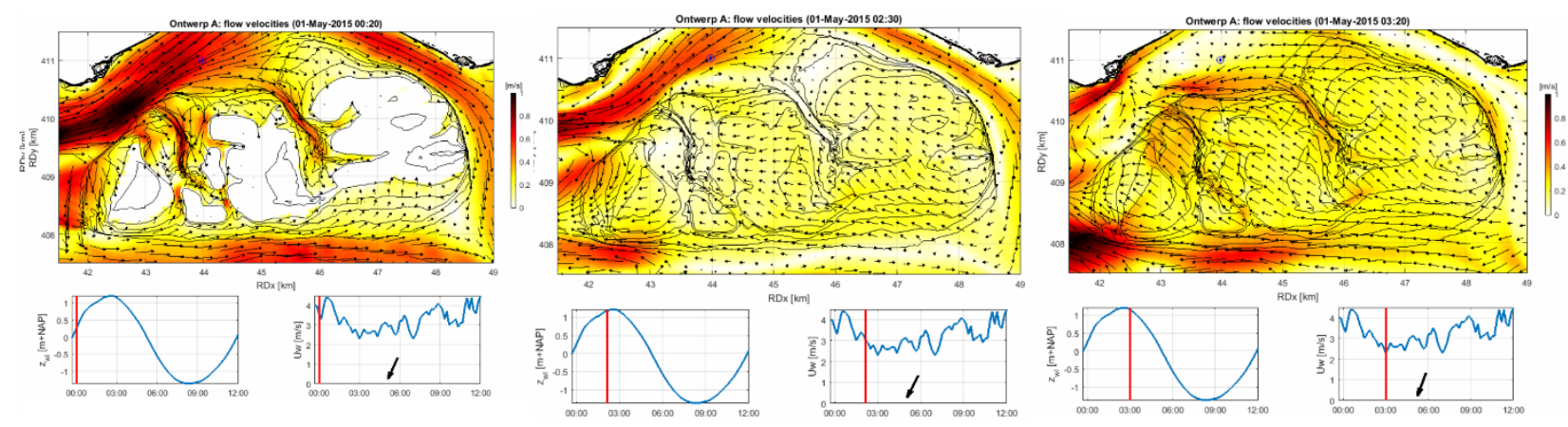

Figuur 7-7 Stromingen op de Roggeplaat en in het Middengeultje net voor, tijdens, en net na hoogwater op basis van modeloutput van Deltares.

\subsection{Benthische diatomeeën}

\subsubsection{Methode}

Door de aanleg van de suppletie zou het aandeel benthische diatomeeen dat de plaat af stroomt kunnen veranderen, en daarmee de voedseltoevoer naar de mosselpercelen gelegen aan de monding van het Middelgeultje. Om te onderzoeken hoe belangrijk het aandeel van benthische diatomeeën (microfytobenthos) is in de algenbiomassa van het Middengeultje zijn watermonsters genomen. Watermonsters zijn genomen voor ( 11 juni 2019 en 26 augustus 2019) en na (22 december 2019, 15 mei 2020 en 12 oktober 2020) aanleg van de suppleties conform de methode beschreven in Walles et al. 2021. Ten tijde van deze rapportage zijn niet alle gegevens beschikbaar, voor zowel de gemeten chlorofyl-a als stabiele isotopen. Deze onderdelen zullen daarom in een vervolgrapportage aan bod komen. Verder zijn van de diatomeeën-gemeenschap, die in dit hoofdstuk wordt besproken, alleen de data van 11 juni 2019, 26 augustus 2019 (beide T0) en 15 mei 2020 geanalyseerd.

\subsubsection{Resultaten: aandeel bentische diatomeeën}

De hoogste dichtheden van zowel benthische als pelagische algen komen voor tijdens de meting in mei 2020, na aanleg van de suppleties (Figuur 7-8). Tijdens deze metingen 
pieken de concentraties bij de meeste meetpalen rond 1 uur na hoogwater. Benthische algen, gemeten bij meetpaal 1 en 2, pieken iets eerder, bij 1 uur voor hoogwater. Na het bereiken van deze piek neemt de concentratie af, die bij meetpaal 4 weer licht toeneemt rond 4 uur na hoogwater, voor zowel benthische als pelagische algen. Doordat er niet gemeten is na dit tijdstip, is het niet duidelijk of deze stijgende trend zich voortzet.

Tijdens de bemonsteringen in juni (T0) zien we bij veel meetpalen een piek rond of net na hoogwater gevolgd door een afname (Figuur 7-9). Bij sommige meetpalen is ook te zien hoe de algenconcentratie licht omhoog gaat rond vier uur na hoogwater. Opvallend hierbij is, dat tijdens de bemonstering in juni, benthische diatomeeën in veel lagere dichtheden voorkomen dan tijdens de bemonstering in november. Voor de pelagische algen is deze trend juist weer andersom, en zijn er vooral voor hoogwater meer algen gemeten in juni.

Wanneer de watermonsters vergeleken worden met die van de meetpalen (Figuur 7-4 en Figuur 7-5), is te zien dat er in de meetpaalmetingen na hoogwater ook een (kleinere) piek voorkomt, dit is vooral zichtbaar bij turbiditeit. Het is mogelijk dat de piek die tijdens de algenbemonstering is geobserveerd deze tweede piek treft. Er valt echter vanuit de opgenomen data niet te concluderen of er daadwerkelijk een grote piek voorkomt voor de start van de meting. Hierdoor is het dus ook niet mogelijk om een uitspraak te doen over de patronen van de gemeten algenconcentraties in verhouding tot het getij.

Het hoogste aandeel aan benthische diatomeeën is geobserveerd tijdens de meting in November 2019 (Figuur 7-10). Bij meetpaal 1 en 2, op 22 november 2019, is het aandeel tychopelagische algen drie uur na hoogwater ongebruikelijk hoog. Dit wordt vooral veroorzaakt door 2 soorten: Odontella aurita en Brockmaniella brockmannii.
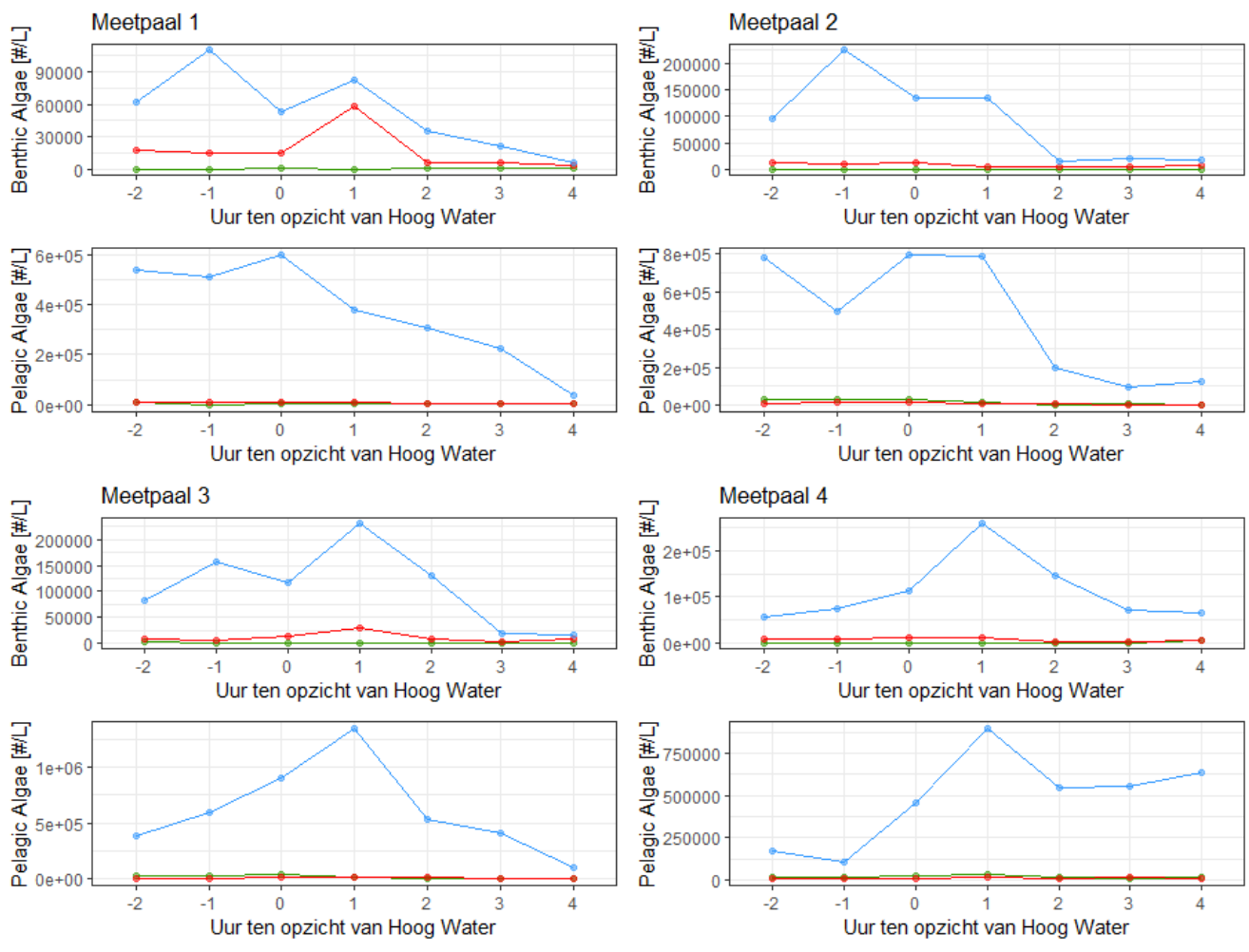

Datum $\rightarrow$ 2019-06-11 $\rightarrow$ 2019-11-22 $\rightarrow$ 2020-05-11

Figuur 7-8 Verloop van benthische en pelagische algenconcentraties ten opzichte van het getij tijdens de bemonstering van 11 juni en 22 november 2019 (T0) en 11 mei 2020 (T1). 

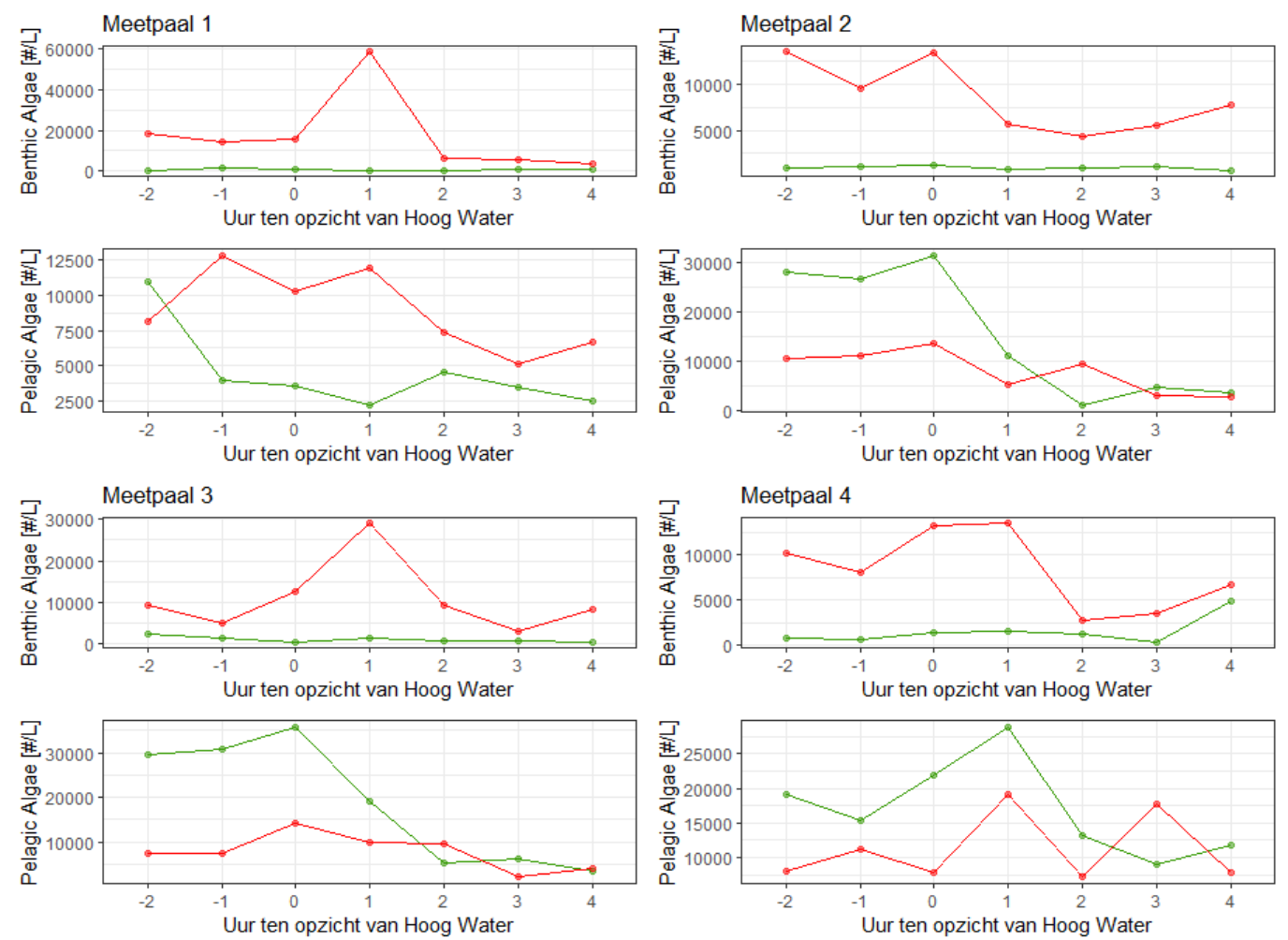

Datum $\rightarrow$ 2019-06-11 $\rightarrow$ 2019-11-22

Figuur 7-9 Verloop van benthische en pelagische algenconcentraties ten opzichte van het getij tijdens de bemonstering van 11 juni en 22 november 2019 (T0).

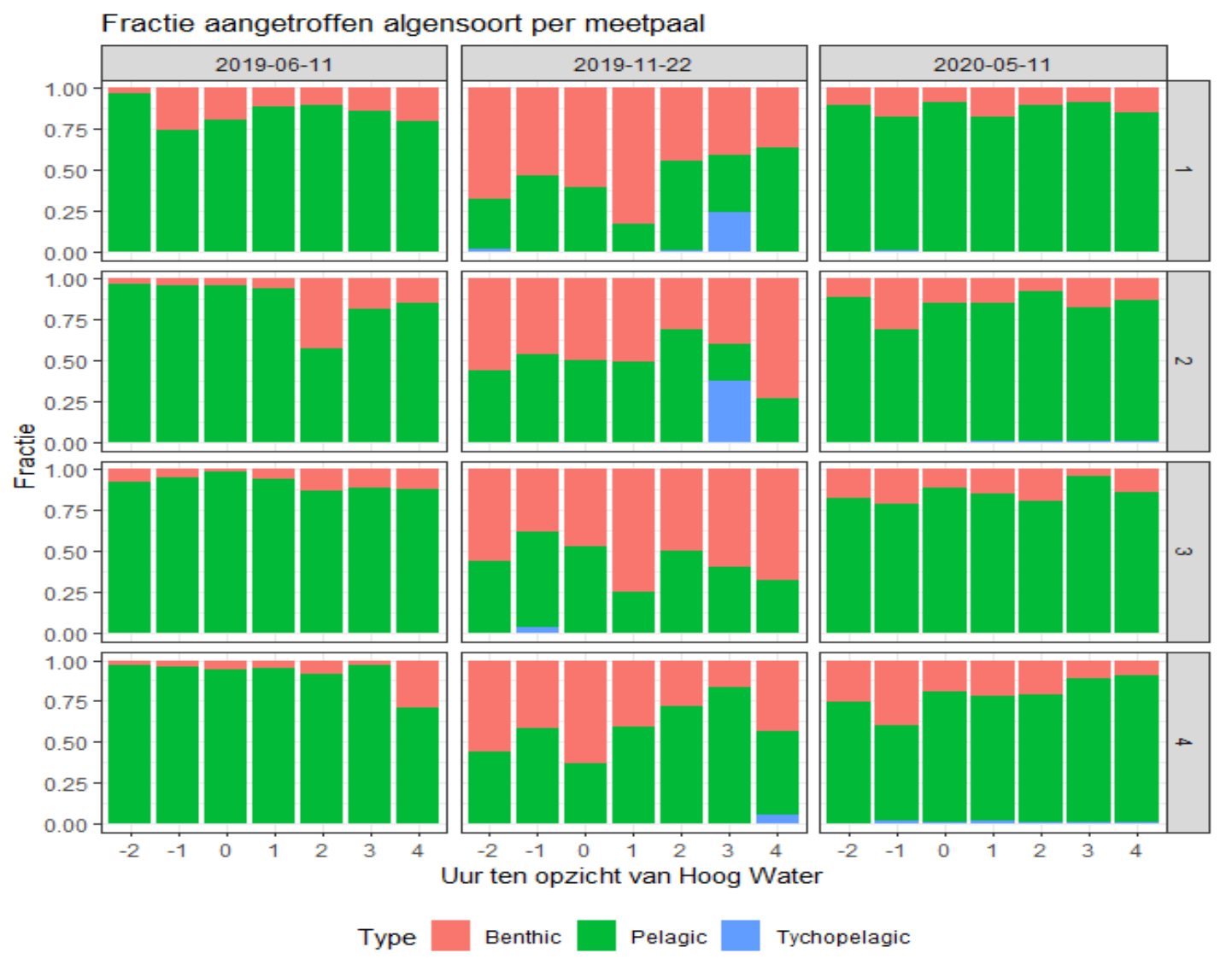

Figuur 7-10 Fractie van bentische, pelagische en tychopelagische diatomeeën geobserveerd in de monsters genomen uit en rondom de Middengeul. 


\subsubsection{Resultaten: Per soort}

In totaal zijn 74 soorten geïdentificeerd, waarvan 18 benthisch, 52 pelagisch, 2 benthisch/pelagisch en 2 tychopelagisch. De meest voorkomende soorten, gevonden tijdens de bemonstering, zijn de pelagische soorten Pseudonitzschia seriata en Pseudonitzschia delicatissima en de benthische soort Paralia sulcata (Tabel 11). Deze drie soorten nemen samen $81 \%$ van de totale tellingen in beslag. Bij meetpaal 1 worden de laagste gemiddelde concentraties geobserveerd, waarbij de concentraties richting de monding van de Middengeul toe lijken te nemen en bij meetpaal 3 het hoogst zijn.

De drie meest voorkomende soorten hebben de hoogste concentraties bij de meting in mei 2020, verder is een vergelijkbaar patroon te zien waarbij de concentratie snel afneemt na een piek rond hoogwater/1 uur na hoogwater (Figuur 7-11). Paralia sulcata wordt, in verhouding tot de andere twee soorten, veel meer tijdens de november 2019 bemonstering gezien. Pseudonitzschia delicatissima wordt weinig waargenomen in juni, helemaal niet in november maar weer wel veel tijdens de T1 bemonstering in mei 2020 .

Het is uit de, in deze paragraaf gepresenteerde, data niet duidelijk af te leiden of de toelevering naar de percelen, voornamelijk uit benthische of pelagische algen bestaat. Verder valt er weinig tot geen conclusie te trekken over de verandering in samenstelling van algen na aanleg van de suppletie. Hiervoor is de variatie tussen de genomen monsters te groot en is er vooral sprake van momentopnamen.

Tabel 11 Gemiddelde dichtheid (\#/I) en voorkomen (\% van monsters waar soort is aangetroffen) van een aantal belangrijke en veelvoorkomende soorten. Grijze rijen geven benthische soorten weer.

Algensamenstelling Middengeultje

\begin{tabular}{|c|c|c|c|c|c|c|c|c|}
\hline & \multicolumn{2}{|c|}{$\begin{array}{c}\text { Meetpaal } 1 \\
n=21\end{array}$} & \multicolumn{2}{|c|}{$\begin{array}{c}\text { Meetpaal } 2 \\
n=21\end{array}$} & \multicolumn{2}{|c|}{$\begin{array}{c}\text { Meetpaal } 3 \\
n=21\end{array}$} & \multicolumn{2}{|c|}{$\begin{array}{c}\text { Meetpaal } 4 \\
n=21\end{array}$} \\
\hline & $\mu+\mathbf{s d}$ & $\%$ & $\mu+s d$ & $\%$ & $\mu+\mathbf{s d}$ & $\%$ & $\mu+\mathbf{s d}$ & $\%$ \\
\hline Asterionellopsis glacialis & $1074 \pm 2480$ & 47.1 & $1446 \pm 2846$ & 38.1 & $2120 \pm 3930$ & 57.1 & $578 \pm 1244$ & 38.1 \\
\hline Bellerochea spp. & $713 \pm 1393$ & 47.6 & $1819 \pm 3185$ & 71.4 & $2707 \pm 5938$ & 71.4 & $2951 \pm 4239$ & 71.4 \\
\hline Chaetoceros spp. & $5885 \pm 16127$ & 66.7 & $2116 \pm 5587$ & 38.1 & $3686 \pm 6648$ & 52.4 & $1691 \pm 4756$ & 33.3 \\
\hline Delphineis surirella & $3209 \pm 7293$ & 38.1 & $4243 \pm 10655$ & 42.9 & $4478 \pm 9243$ & 47.6 & $7793 \pm 15062$ & 38.1 \\
\hline Grammatophora marina & $104 \pm 244$ & 23.8 & $60 \pm 96$ & 33.3 & $69 \pm 207$ & 19.0 & $1283 \pm 3871$ & 23.8 \\
\hline Guinardia delicatula & $11997 \pm 23110$ & 85.7 & $8564 \pm 13609$ & 85.7 & $3576 \pm 5978$ & 90.4 & $4865 \pm 6783$ & 95.2 \\
\hline Leptocylindrus minimum & $1057 \pm 2107$ & 61.9 & $377 \pm 1052$ & 28.6 & 0 & 0 & 0 & 0 \\
\hline Leptocylindrus danicus & $736 \pm 1313$ & 47.6 & $3214 \pm 5715$ & 61.9 & $2914 \pm 4843$ & 42.9 & $2062 \pm 3398$ & 42.9 \\
\hline Navicula spp. & $1006 \pm 1160$ & 90.5 & $1701 \pm 2745$ & 90.5 & $2105 \pm 3002$ & 95.2 & $2489 \pm 3130$ & 90.5 \\
\hline Nitzschia spp. & $731 \pm 888$ & 85.7 & $387 \pm 441$ & 76.2 & $925 \pm 1608$ & 85.7 & $1062 \pm 4314$ & 76.2 \\
\hline Odontella aurita & $554 \pm 1375$ & 28.6 & $879 \pm 1455$ & 42.9 & $266 \pm 899$ & 28.6 & $1970 \pm 4164$ & 42.9 \\
\hline Paralia sulcata & $16423 \pm 22197$ & 90.5 & $25467 \pm 51515$ & 90.5 & $29331 \pm 53651$ & 85.7 & $27138 \pm 46553$ & 100.0 \\
\hline $\begin{array}{l}\text { Pseudonitzschia } \\
\text { delicatissima complex }\end{array}$ & $40289 \pm 75902$ & 57.1 & $53843 \pm 106165$ & 42.9 & $69818 \pm 133550$ & 61.9 & $49506 \pm 96765$ & 33.3 \\
\hline $\begin{array}{l}\text { Pseudonitzschia seriata } \\
\text { complex }\end{array}$ & $57518 \pm 111434$ & 90.4 & $81866 \pm 161780$ & 85.7 & $114257 \pm 243558$ & 81.0 & $98220 \pm 178753$ & 90.4 \\
\hline Rhizosolenia imbricata & $591 \pm 652$ & 76.2 & $1234 \pm 1389$ & 76.2 & $1321 \pm 1407$ & 81.0 & $1005 \pm 1043$ & 66.7 \\
\hline Skeletonema spp. & $750 \pm 3291$ & 9.5 & $700 \pm 1898$ & 19.0 & $732 \pm 1876$ & 19.0 & $215 \pm 987$ & 4.8 \\
\hline Thalassionema nitzschiodes & $529 \pm 779$ & 61.9 & $1259 \pm 1394$ & 76.2 & $818 \pm 950$ & 71.4 & $1722 \pm 1479$ & 76.2 \\
\hline Thalassiosira spp. & $324 \pm 714$ & 52.4 & $749 \pm 1549$ & 57.1 & $1022 \pm 2363$ & 66.7 & $884 \pm 1420$ & 81.0 \\
\hline Thalasiosira constricta & 0 & 0 & $2879 \pm 7692$ & 14.3 & 0 & 0 & 0 & 0 \\
\hline Alle Soorten & $152245 \pm 23$ & 555 & $200258 \pm 338$ & 323 & $252696 \pm 425$ & & $218813 \pm 336$ & 508 \\
\hline
\end{tabular}




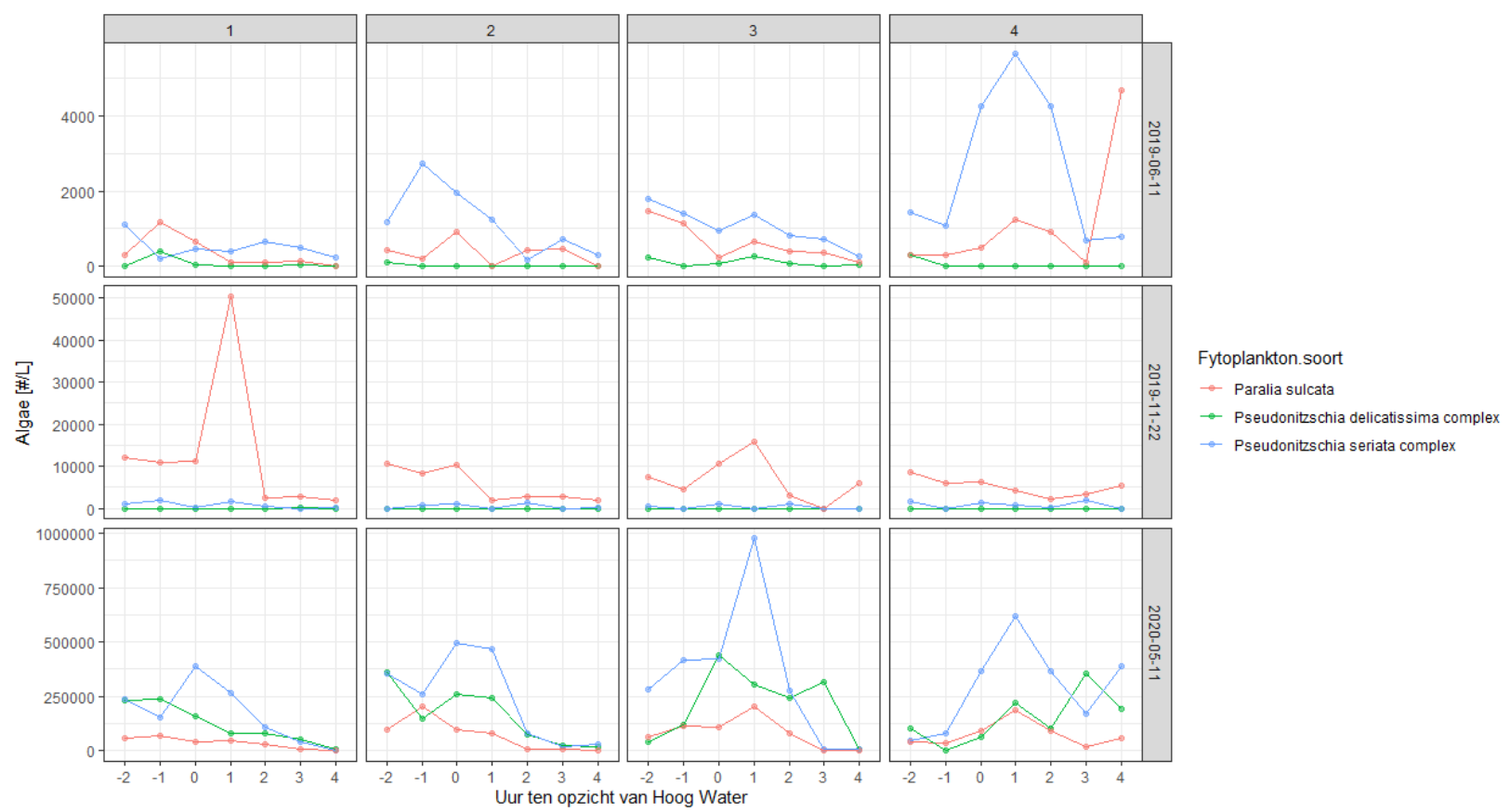

Figuur 7-11 Verloop van de drie meest voorkomende soorten tegenover tij voor elke meetpaal en meetmoment.

\subsection{Metingen Sensorboot $\mathrm{HZ}$}

\subsubsection{Methode}

Hogeschool zeeland heeft in mei 2019 en september 2020 metingen gedaan met een sensorboot, rond de monding van de Middengeul, naar de troebelheid en chlorofylgehaltes in de bovenste waterlaag, 30-50 centimeter van het wateroppervlak. Hierbij is vooral gekeken naar de ruimtelijke verspreiding van deze parameters. Doordat alleen het bovenste deel van de waterkolom is bemonsterd, is het niet mogelijk om verregaande conclusies te trekken over direct transport van deeltjes naar de mosselpercelen. Wel is het mogelijk om de resultaten te vergelijken met eerdere resultaten uit de meetpalen. De metingen zijn uitgevoerd tijdens rustig weer.

\subsubsection{Resultaten}

De resultaten uit de troebelheidsmetingen laten vooral zien dat in de dynamische zone rondom de oesterbanken sedimenttransport plaatsvindt (Figuur 7-12). Tijdens de T0 is te zien dat de troebelheid zeer laag is in het Middengeultje en in het westelijke deel van de monding van het Middengeultje. Verder is de troebelheid licht verhoogd in het meest oostelijk deel in het mondingsgebied. Opvallend hierbij is dat deze verhoogde troebelheid voor aanleg van de suppletie tot ver buiten het mondingsgebied reikt. De maximaal gemeten troebelheid is tijdens de gehele T0 echter zeer laag. Dit komt vermoedelijk door het tijdstip van meten bij hoogwater.

$\mathrm{Na}$ aanleg van de suppletie (T1), neemt troebelheid toe tijdens opkomend water (Figuur 7-13). Er is een duidelijk verschil tussen de metingen aan de westelijke plaatrand, een plaatrand zonder natuurlijke oesterbanken en de metingen aan de oostelijke plaatrand, een plaatrand met natuurlijke oesterbanken. De westelijke plaatrand geeft een rustig beeld, waarbij alleen zeer dicht op de plaatrand hoge waarden aan turbiditeit worden 
gemeten. Dit leidt tot de conclusie dat de verhoogde troebelheid in het oostelijk gebied zich beperkt tot dicht bij de plaatrand. De concentratie aan deeltjes in het oppervlaktewater vermindert snel met toenemende afstand tot de plaatrand. Dit betekent dat deeltjestransport vanaf de westelijke plaatrand tijdens deze meetdag in noordelijke richting niet kan worden aangetoond. Het oppervlaktewater ten westen van het Middengeultje lijkt geen transportmedium van deeltjes naar de noordelijker gelegen mosselpercelen op deze betreffende meetdag. Op basis van de meetgegevens kan niet worden aangetoond of er fundamentele verschillen zijn in afstand tot de westelijke plaatrand waar troebelheid gemeten is tussen de T0 en T1.

Tijdens de T0 meting is ook chlorofyl-a-concentratie in het oostelijke deel veel hoger dan de westelijke (Figuur 7-12). In tegenstelling tot de troebelheidsdata van T1, is er geen verschil tussen de chlorofyl-a concentratie in het westelijke versus het oostelijke deel. De concentratie chlorofyl-a gemeten in september is echter laag. Een uitzondering vormt het traject gemeten vlak boven de natuurlijke oesterbanken (Figuur 7-13), waar de chlorofyl-a concentratie hoger is ( $>20$ NTU). T1 meting laat dus lagere waarden aan chorofyl-a zien. Echter is deze variatie te verklaren door de verschillende meetmomenten in het seizoen (eerste in mei en tweede in september). Met deze data kan niet aangetoond worden welk effect de suppleties op chlorofyl en vertroebeling hebben.

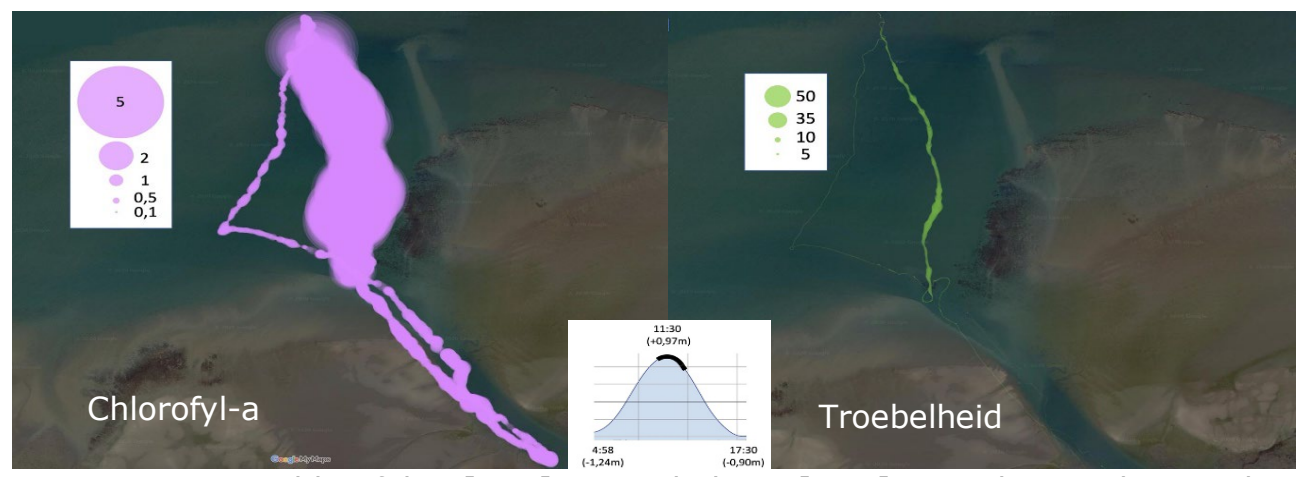

Figuur 7-12 Gemeten chlorofyl-a [RFU] en turbiditeit [NTU] waarden in de monding van het Middengeultje, met de sensorboot van het $\mathrm{HZ}$, tijdens de t0 meting in mei 2019. Het signaal is weergegeven met bollen die in grote toenemen varieren afhankelijk van de gemeten concentratie.

\subsubsection{Resultaten: koppeling meetpalen}

Wanneer het verloop van de resultaten in verhouding tot het getij, worden vergeleken met dat van de meetpalen is er te zien dat net voor hoogwater (Figuur 7-13, onderste situatie), wanneer de plaat onderloopt, veel hogere waarden aan troebelheid (NTU) aan de oostkant van de middelgeul worden geobserveerd maar in het Middengeultje zelf niet. Dit is het moment dat de meetpalen in het Middengeultje over het algemeen juist de hoogste concentraties aan chlorofyl en turbiditeit meten. Echter, geven de metingen genomen op de sensorboot de waarden aan het oppervlakte weer, terwijl de meetpalen juist dicht bij de bodem meten. Een mogelijkheid is dus dat door de kentering, die op dit moment plaatsvind, alles naar beneden zakt in het Middengeultje en dus niet aan het oppervlakte te meten valt, terwijl bij het oesterrif deeltjes gesuspendeerd in de waterkolom blijven. Dit wordt mogelijk veroorzaakt door de natuurlijke oesterbanken die een harde heterogene structuur vormen. Stroming over een harde heterogene structuur vergroot de turbulentie sterk waardoor deeltjes langer in de waterkolom aanwezig kunnen blijven. Verder kunnen harde heterogene structuren ook een drempel zijn voor deeltjes waardoor de bron van de deeltjes ook hoger ligt in de waterkolom. 

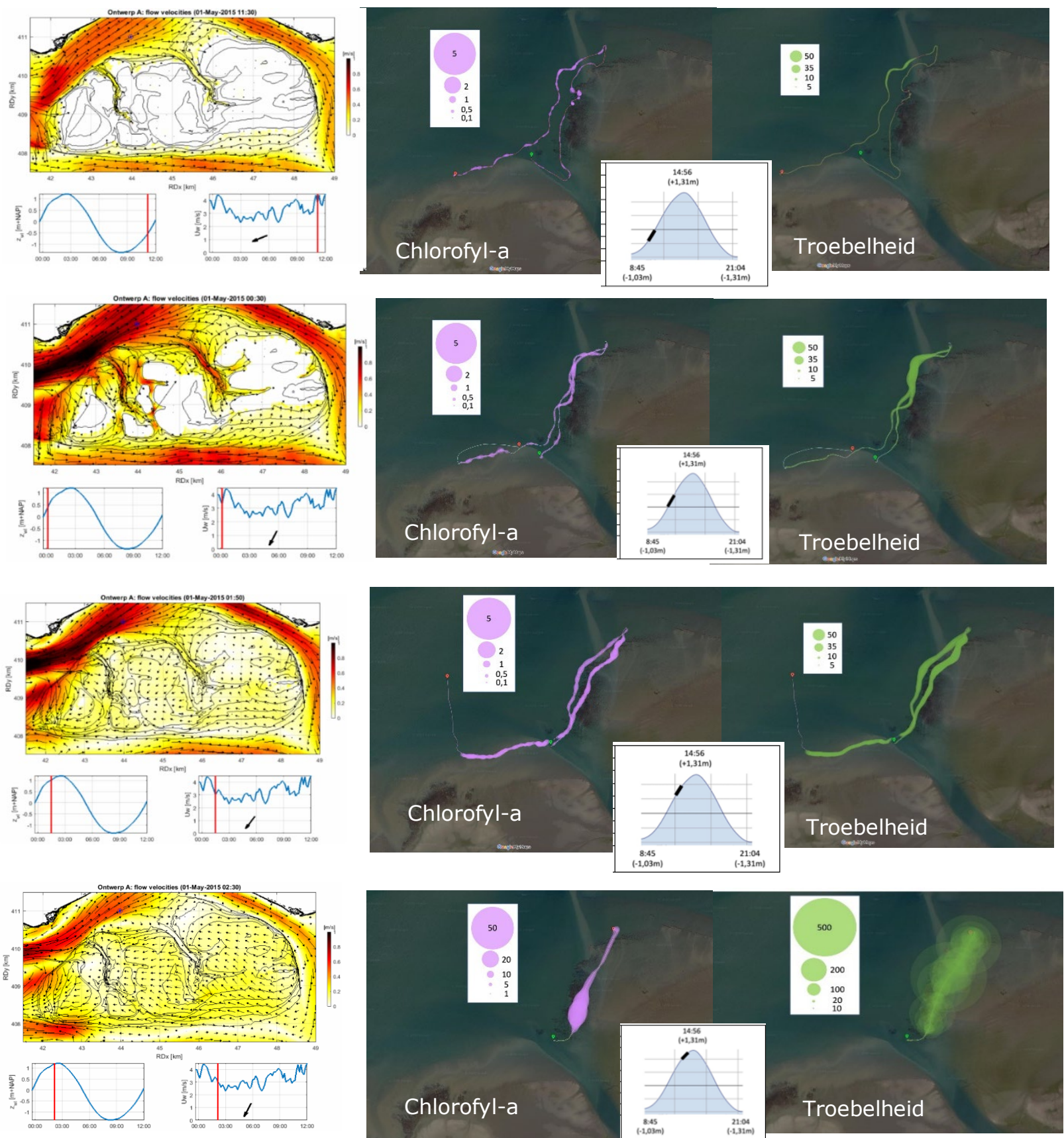

Figuur 7-13 Gemeten chlorofyl-a [RFU] en turbiditeits [NTU] waarden in de monding van het Middengeultje, met de sensorboot van het $\mathrm{HZ}$, tijdens de $\mathrm{T} 1$ meting in september 2020. 


\section{Mosselpercelen rond de Roggenplaat: algemene karakteristieken en kwaliteit}

\subsection{Doel}

Om de eventuele effecten op de mosselpercelen in kaart te brengen is een specifiek monitoringsplan opgesteld voor de mosselpercelen rond de Roggenplaat (Wijsman en Kraan, 2017). In de volgende paragrafen worden de resultaten van deze monitoring gepresenteerd vanaf de start van de monitoring in 2018 tot en met december 2020, ruim een jaar na aanleg van de suppletie.

Langs de randen van de Roggenplaat liggen een groot aantal percelen die door mosselkwekers worden gebruikt voor het kweken van consumptiemosselen (Figuur 8-1). Aan de noordzijde, in de Hammen liggen 13 mosselpercelen waarvan er 12 zijn verhuurd (Wijsman en Kraan, 2017). De oostelijke percelen (H68A tot en met H85) worden maar beperkt gebruikt. De percelen H68B tot en met $\mathrm{H} 71$ liggen relatief ondiep in de monding van het Middengeultje. Aan de zuidzijde in de Geul van de Roggenplaat liggen 16 percelen, waarvan er 14 zijn verhuurd. De percelen H98, H99 en H100 worden beperkt gebruikt.

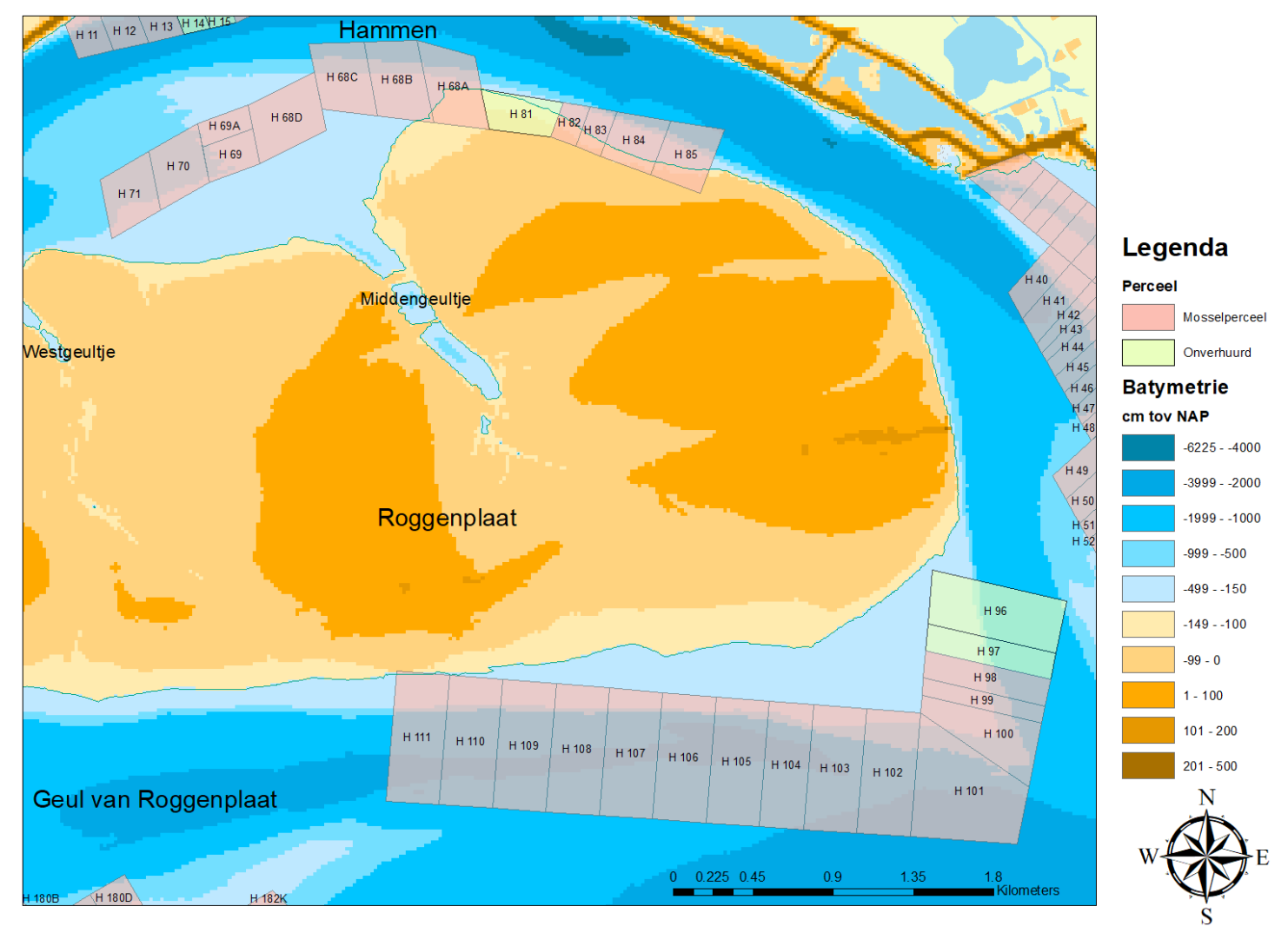

Figuur 8-1: Ligging van de mosselpercelen rond de Roggenplaat.

De mogelijke effecten van de Roggenplaatsuppletie op de nabijgelegen mosselpercelen zijn uitgewerkt in een risicostudie (Lievense et al., 2016). Deze risicobeoordeling is tot 
stand gekomen vanuit een samenwerking tussen Rijkswaterstaat Zee en Delta, Natuurmonumenten, het Ministerie van Economische Zaken en de mosselkwekers (PO mossel). De belangrijkste risico's die zijn gedefinieerd binnen de risicostudie zijn:

1. Verstikking van mosselen op de percelen door begraving aan de noordzijde van de Roggenplaat door uitzakken van fijn gesuspendeerd sediment dat opwerveld vanaf de suppleties;

2. Vermindering van de kwaliteit van de percelen door toename van aanzanding;

3. Verslechtering van kweekomstandigheden door een toename van verstuivend zand naar de percelen welke tot aanzanding leidt op de percelen.

Tevens zou de aanvoer van voedsel via het Middengeultje van de plaat naar de percelen aan de noordzijde kunnen veranderen.

\subsection{Aanvoer van mosselen van de percelen}

De aanvoer van de mosselen van de percelen wordt geregistreerd door de mosselveiling. Voor deze studie zijn de veilinggegevens van de leveringen uit de Oosterschelde gebruikt vanaf mei 2000 tot en met 18 november 2020. In totaal liggen er 336 mosselpercelen in de Oosterschelde (waarvan 27 onverhuurd) met een totaal oppervlak van ca 4000 ha (Figuur 8-2). Voor de analyses zijn de percelen in blokken gegroepeerd (1 t/m 22), waarbij de perceelblokken $1 \mathrm{t} / \mathrm{m} 9$ de Hammen percelen zijn, de blokken 10 en 12 de Zandkreek percelen, blok 11 en blokken 13 t/m 19 OSWD en blokken 20 t/m 22 de Mastgat percelen. In de praktijk wordt slechts een deel van het perceel daadwerkelijk gebruikt voor mosselkweek (Wijsman et al., 2010).

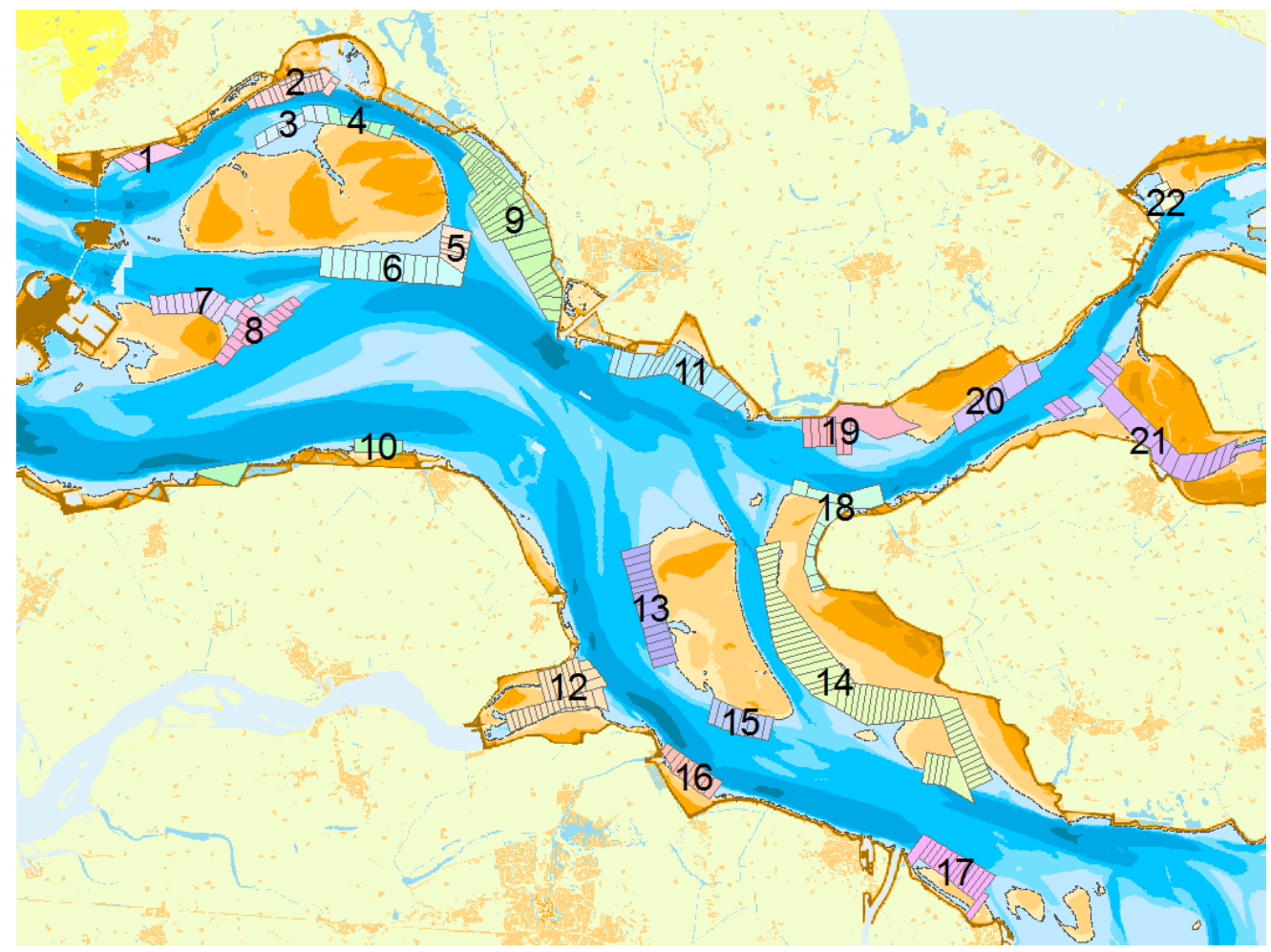

Figuur 8-2: Ligging van de mosselpercelen in de Oosterschelde. De percelen zijn in deze figuur gegroepeerd in 22 perceelblokken (Wijsman, 2017). 


\subsubsection{Aanvoer gehele Oosterschelde}

De gemiddelde aanvoer van de percelen in de Oosterschelde is over de gehele periode (2000_2001 tot en met 2020_2021) 24.4 miljoen kg mosselen per jaar (Figuur 8-3). Een seizoen is hierbij gedefinieerd als de periode vanaf 1 mei tot en met 30 april van het jaar erop. De maximale aanvoer was 38.0 miljoen $\mathrm{kg}$ in het seizoen 2004_2005 en de minimale aanvoer was 14.0 miljoen $\mathrm{kg}$ in het seizoen 2007_2008. De meeste mosselen komen uit de deelgebieden Hammen (63.1\%) en OSWD (32.3\%). De data voor het laatste seizoen (2020_2021 zijn nog niet volledig en lopen tot en met 18 november 2020). Leveringen uit de andere deelgebieden zijn beperkt ( $4.6 \%$ van de totale aanvoer). Het gebied Hammen is door de tijd steeds belangrijker geworden voor de totale aanvoer uit de Oosterschelde. In de seizoenen 2000-2001 tot en met 2009-2010 kwam $48.3 \%$ van de totale aanvoer uit de Oosterschelde van de Hammenpercelen. In de seizoenen 2010-2011 tot en met 2020-2021 kwam 75.8\% van de totale aanvoer van de Hammenpercelen.

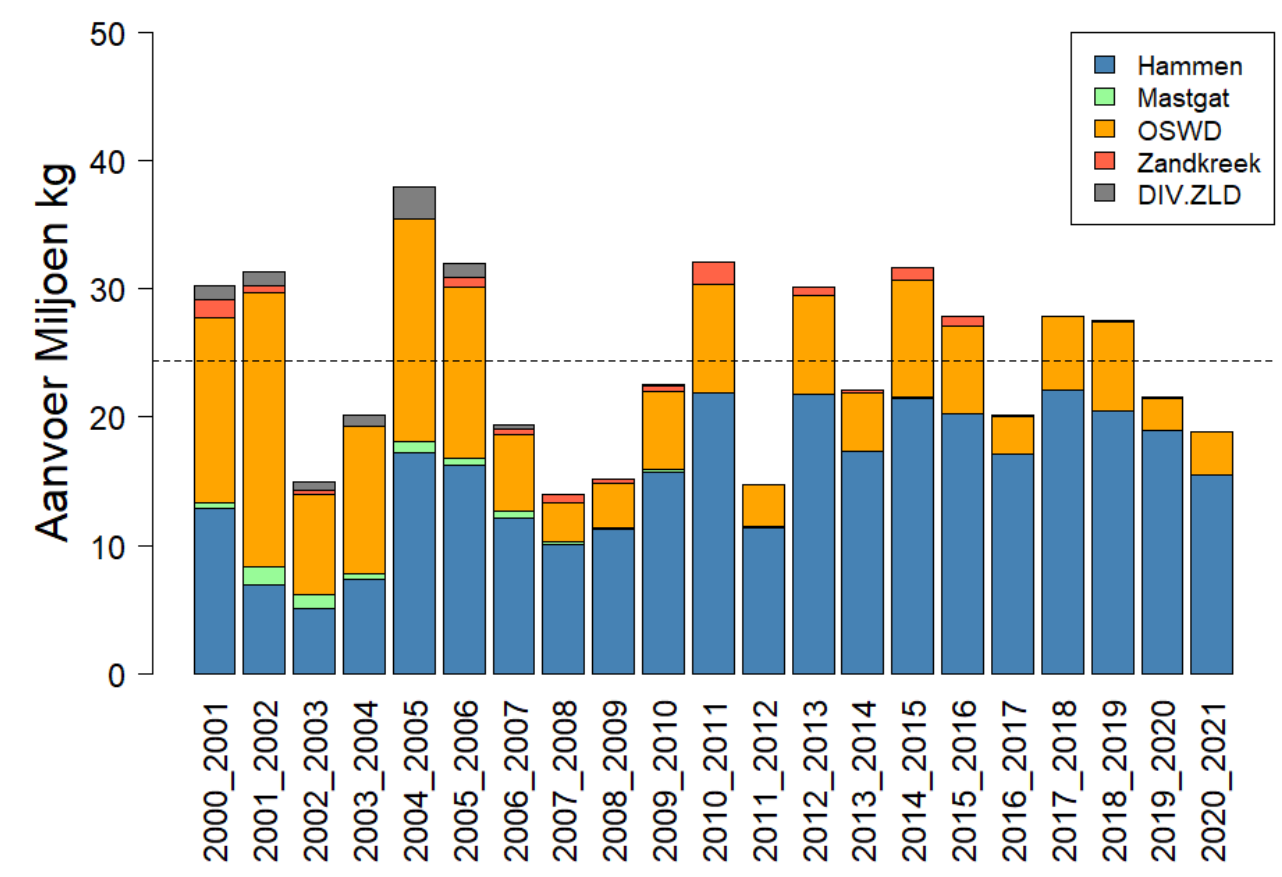

Figuur 8-3: Netto aanvoer (miljoen $\mathrm{kg}$ ) per seizoen uit de verschillende deelgebieden in de Oosterschelde: Hammen (blokken 1 tot en met 9), OSWD (blokken 11 en 13 tot en met 19), Zandkreek (blok 10 en 12) en Mastgat (blokken 20 tot en met 22)(zie ook Wijsman, 2017). De data voor seizoen 2020_2021 zijn niet compleet en lopen tot en met 18 november 2020.

De meeste aanvoer van de percelen uit de Oosterschelde vindt plaats in de maanden juli en augustus, en daarna neemt de aanvoer vanuit de Oosterschelde geleidelijk af (Figuur 8-4). De aanvoer heeft een relatie met de vraag en aanbod en ook met de kwaliteit van de mosselen die ook varieert door het seizoen (Figuur 8-5). In de analyses is aangenomen dat het seizoen loopt van 1 mei tot en met 30 april. 


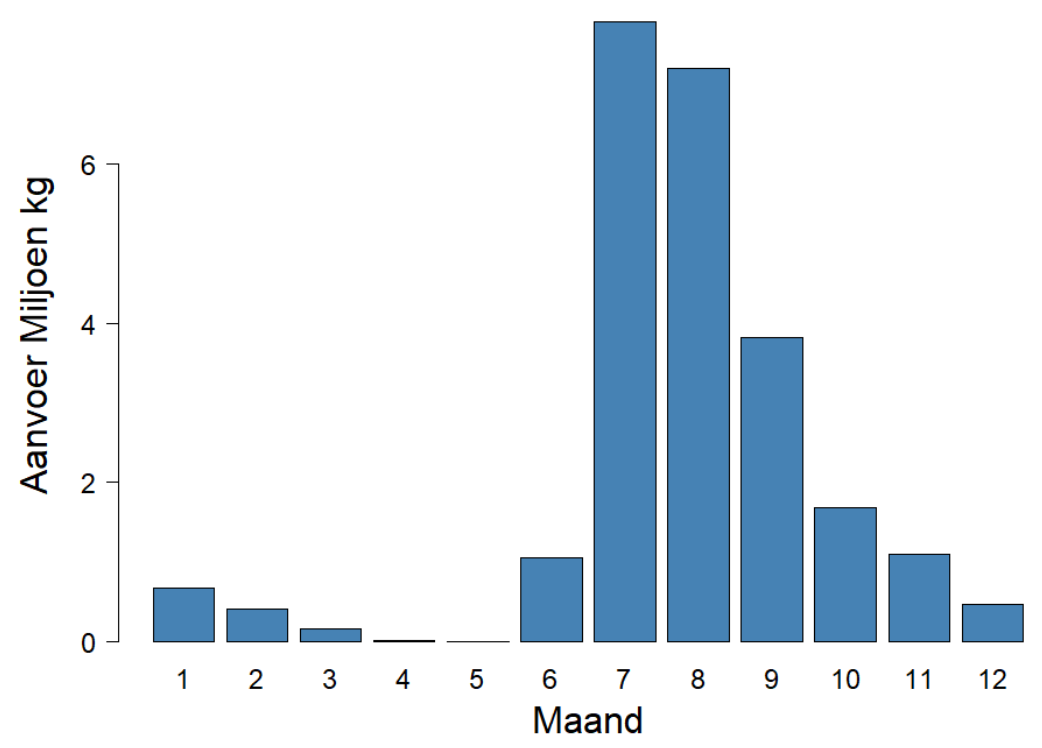

Figuur 8-4: Maandelijke fluctuaties in de netto aanvoer (miljoen $\mathrm{kg}$ ) van mosselen van de percelen in de Oosterschelde. De gegevens zijn gemiddeld per maand over alle seizoenen (2000_2001 tot en met 2020_2021).

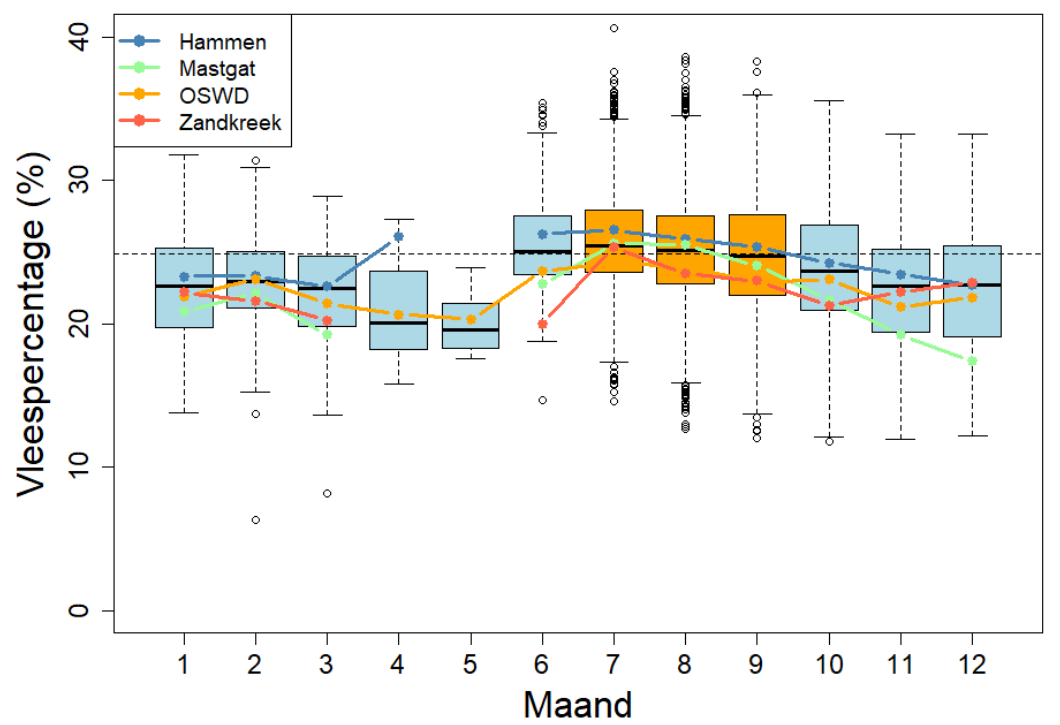

Figuur 8-5: Maandelijkse fluctuaties in het vleespercentage (\%) van mosselen van de percelen in de Oosterschelde. De boxplots geven de variatie van alle leveringen uit de Oosterschelde. De oranje boxen geven de drie belangrijkste maanden voor de Oosterschelde weer (juli, augustus en september). De gekleurde lijnen geven het gewogen gemiddelde vlees-percentage voor de percelen in respectievelijk Hammen, Mastgat, OSWD en Zandkreek. De stippellijn geeft het gewogen gemiddelde vleespercentage over het hele jaar weer.

De belangrijke perceelblokken waar de mosselen uit worden geleverd zijn de perceelblokken 1 (Burghsluis), 2 (Schelphoek), 3 en 6 (respectievelijk noord- en zuidzijde Roggenplaat), 7 en 8 (respectievelijk noord- en zuidzijde Neeltje Jans), 13 en 15 (Vondelingenplaat) en 14 (Dortsman) (Figuur 8-6). Na 2010 is vooral de aanvoer uit de blokken 1, 3, 6, 7 en 8 toegenomen. Een deel van deze toename is het gevolg van het beschikbaar komen van nieuwe percelen in deze blokken. Voor de interpretatie is 
het van belang dat de oppervlaktes van de perceelblokken sterk varieert (Figuur 8-2). Daarnaast is het van belang dat niet het volledige oppervlakte van het perceelblok wordt gebruikt voor de kweek. Binnen de perceelblokken liggen percelen die niet zijn verhuurd en ook de verhuurde percelen worden maar ten dele gebruikt voor de kweek.
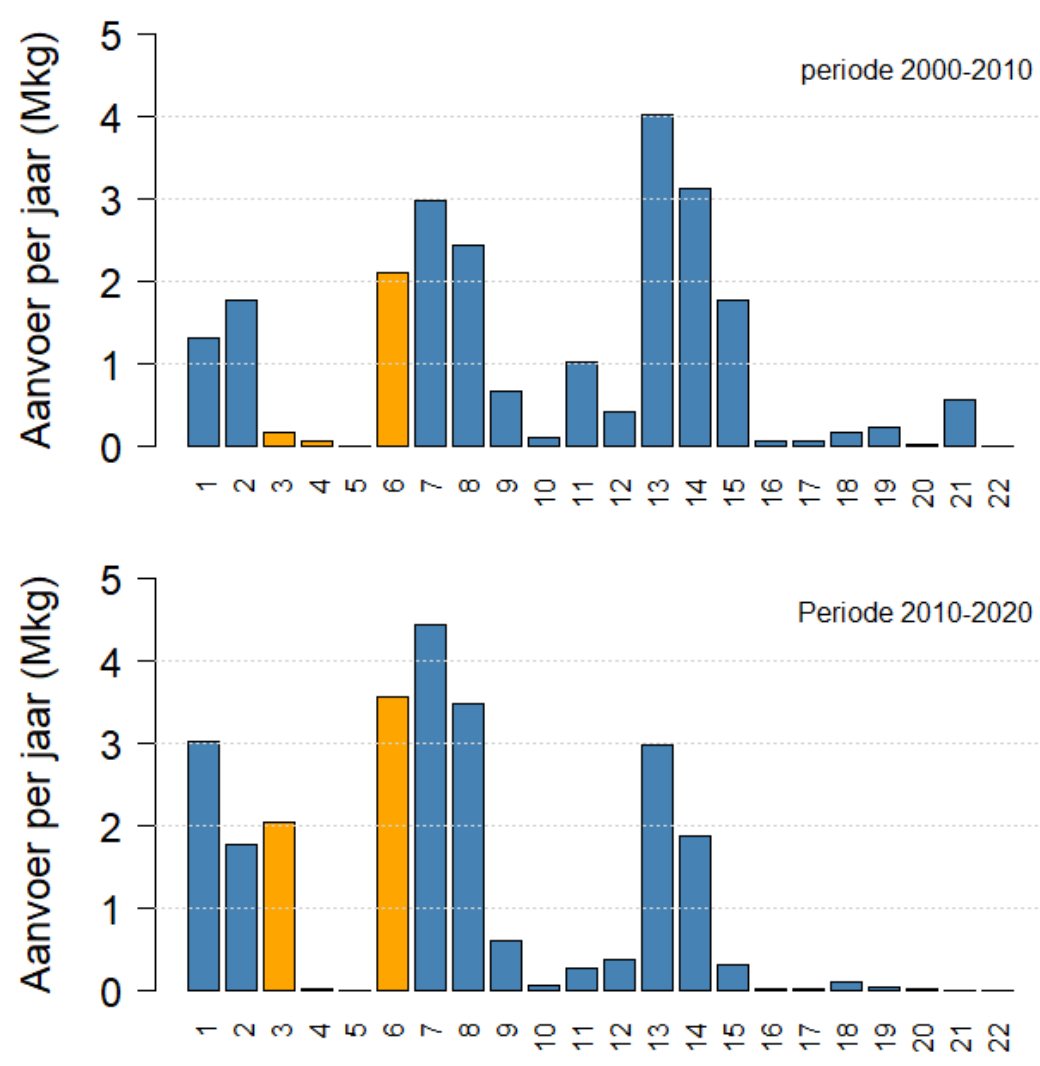

Figuur 8-6: Netto aanvoer (miljoen $\mathrm{kg}$ ) per perceelblok (zie Figuur 8-2). In de bovenste figuur voor de seizoenen 2000_2001 tot en met het seizoen 2009_2010. De onderste figuur voor de periode vanaf het seizoen 2010_2011. De perceelblokken rond de Roggenplaat zijn met de oranje balken aangegeven (zie ook Wijsman, 2017).

\subsubsection{Aanvoer Roggenplaat}

De gemiddelde aanvoer van de perceelblokken rond de Roggenplaat is ongeveer 4.1 miljoen kg per seizoen (2000_2001 tot en met 2020_2021) (Figuur 8-7). Dit is ongeveer $16.6 \%$ van de totale aanvoer van mosselen vanuit de Oosterschelde. De laatste 5 seizoenen (2016_2017 tot en met 2020_2021) was dit zelfs $29.3 \%$ van de totale aanvoer uit de Oosterschelde. Over de hele periode (sinds 2000_2001) worden de meeste mosselen van de Roggeplaat percelen (67\%) geleverd van de percelen aan de zuidzijde van de Roggenplaat (blok 6). De laatste jaren echter (vanaf seizoen 2011_2012) is het belang van blok 3, aan de noordzijde van de Roggenplaat, in de monding van het Middengeultje, toegenomen. Dit is voornamelijk veroorzaakt door een aantal nieuwe percelen die hier zijn aangelegd. Van de percelen binnen blok 4 en blok 5 worden vrijwel geen mosselen geleverd. In het laatste seizoen (2020_2021) is tot en met 18 november 2020 iets minder geleverd dan de jaren ervoor van blok 6. Mogelijk dat er daarna nog is geleverd. Van perceelblok 3 aan de Noordzijde van de Roggenplaat is in seizoen 2020_2021 tot en met 18 november 2020 ongeveer evenveel geleverd als in de voorgaande seizoenen. 


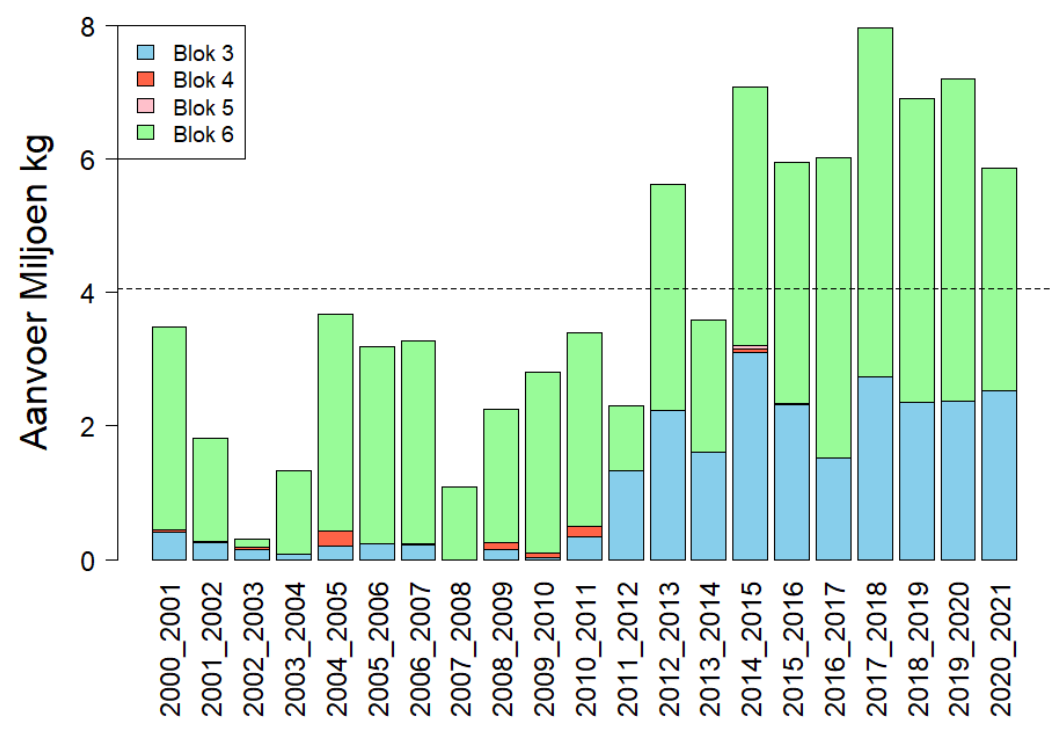

Figuur 8-7: Netto aanvoer (miljoen $\mathrm{kg}$ ) van de perceelblokken rond de Roggenplaat (zie ook Wijsman, 2017).

Het vleespercentage is een maat voor de kwaliteit van de mosselen en is een belangrijke variabele voor de prijs van de mosselen aan de veiling. Het gemiddelde vleespercentage over de hele periode is $25.6 \%$ (Figuur $8-8$ ). In de figuur is te zien dat de vleespercentages van de leveringen uit blok 3 (percelen aan de noordzijde van de Roggenplaat, voor de monding van het Middengeultje) vooral sinds het seizoen 2009_2010 relatieve hoge vleespercentages hebben vergeleken met de rest van de Hammen percelen. Het gemiddelde vleespercentage van blok 6 is over het algemeen lager in deze seizoenen. Van blok 4 en blok 5 is maar beperkt geleverd. Ook in het seizoen 2020_2021 waren de vleespercentages van de mosselen van blok 3 relatief hoog vergeleken met de leveringen van de rest van de Hammenpercelen. 


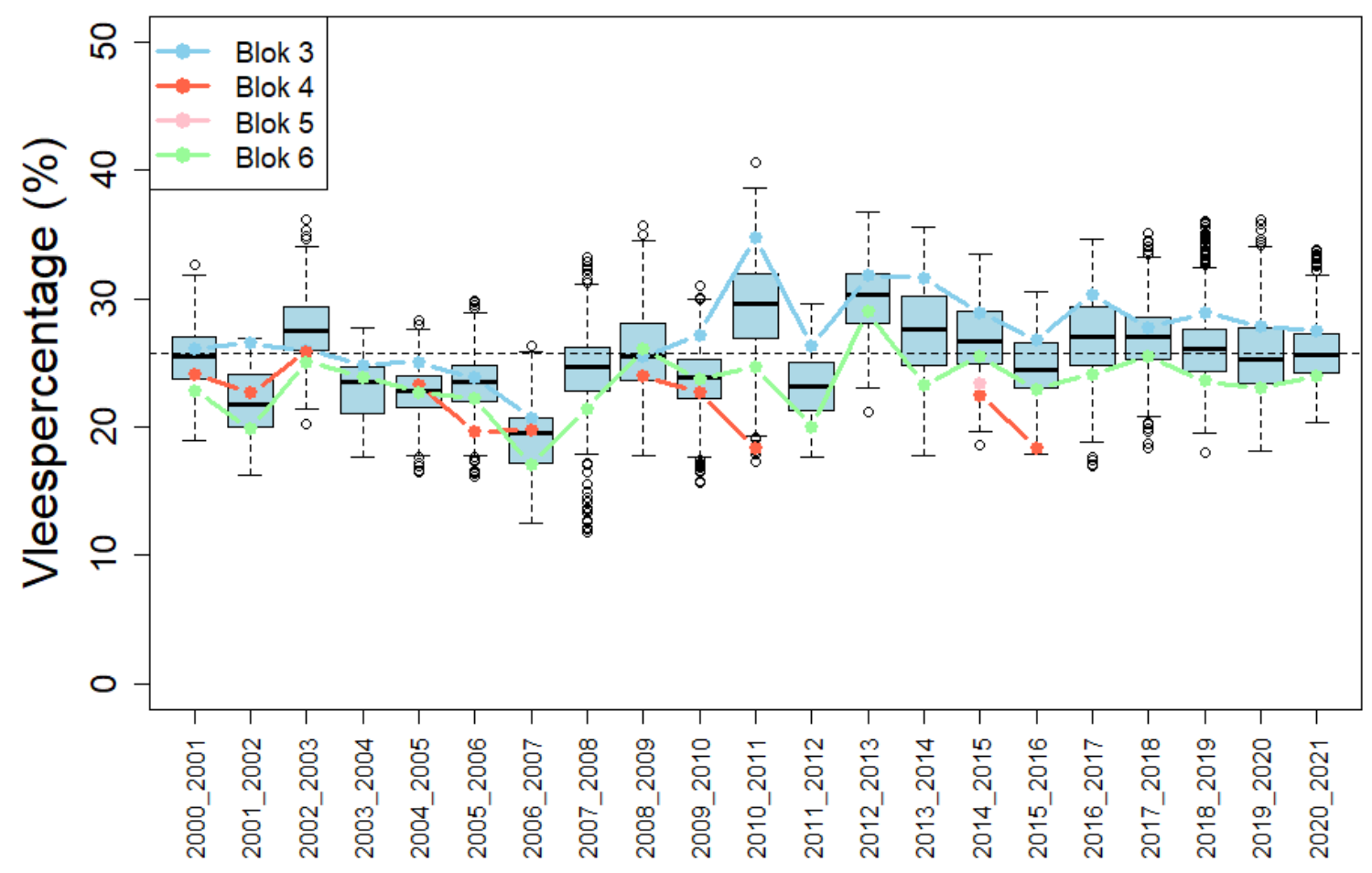

Figuur 8-8: Boxplots van de ontwikkeling van de vleespercentages (gewogen voor de Netto aanvoer) van de Hammen percelen (blok 1 tot en met 9). De horizontale stippellijn geeft het overall gemiddelde weer. De gekleurde lijnen geven het gewogen gemiddelde vlees-percentage voor de blokken rond de Roggenplaat (blok 3, blok 4, blok 5 en blok 6) (zie ook Wijsman, 2017).

\subsection{Ontwikkeling van de mosselen op de percelen}

\subsubsection{Methode}

Om de ontwikkeling van de mosselen op de percelen te volgen worden deze sinds begin april 2018 intensief bemonsterd (Figuur 8-9). In de periode april tot en met augustus vindt deze bemonstering maandelijks plaats en in de rest van het jaar is de bemonstering eens in de twee maanden. Tussen april 2018 en 1 januari 2019, voor aanleg van de suppleties, zijn er 15 perceelbemonsteringen uitgevoerd. Tijdens de aanleg van de suppleties ( 1 oktober - 30 december 2019) zijn 2 perceelbemonsteringen uitgevoerd en 8 na de aanleg van de suppleties. Zie voor een uitgebreide beschrijving van de methode Walles et al (2021).

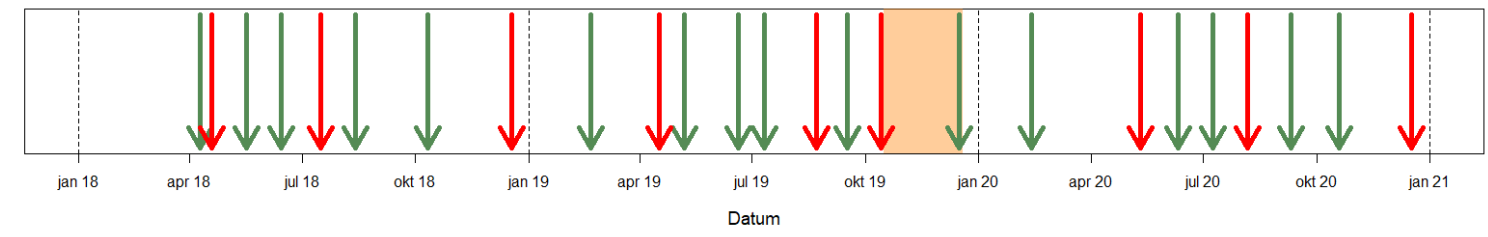

Figuur 8-9: Tijdsbalk met de momenten van de perceelbemonstering voor en na aanleg van de suppleties. De pijlen geven de momenten van de bemonstering. De rode pijlen geven de momenten aan waarbij tevens individuele lengtes van de mosselen en het vleespercentage is bepaald. De periode waarin de suppleties zijn uitgevoerd is aangegeven met de oranje band. 


\subsubsection{Resultaten}

Het gemiddeld gewicht van de mosselen op de percelen rond de Roggenplaat is het resultaat van groei, uitzaaien en oogsten (voornamelijk de grotere consumptiemosselen). De gebruikte maat bustal (Figuur 8-11) is het omgekeerde van het gemiddelde individuele gewicht (bij een laag individueel gewicht hoort een hoog bustal). De afname van het gemiddeld gewicht (en de toename in bustal) in de maanden augustus en september van 2019 wordt waarschijnlijk veroorzaakt door het oogsten van de grote consumptierijpe mosselen van de percelen en het opnieuw inzaaien met kleinere mosselen (Figuur 8-10 en Figuur 8-11). De afname zet al in augustus in, voordat is gestart met de suppleties. Deze afname is ook te zien, zij het in beperktere mate, in het najaar van 2020. De mosselen waren in 2020 bij de start van het seizoen al kleiner dan in 2019. In 2018 was deze afname alleen op de noordelijke percelen te zien. Opvallend is dat het gemiddeld gewicht van de percelen aan de noordzijde van de Roggenplaat (percelen H83, H68, H68b, H68c, H69, H69a, H70 en H71) dat is weergegeven met de blauwe lijn in Figuur 8-10 in alle gevallen groter is dan het gemiddeld gewicht van de mosselen op de percelen aan de zuidzijde van de Roggenplaat (H101 tot en met H111). Hetzelfde patroon is te zien in het bustal (Figuur 8-11), waarbij gemiddeld genomen het laagste bustal (dus de grootste mosselen) wordt aangetroffen op de percelen aan de noordzijde van de Roggenplaat.

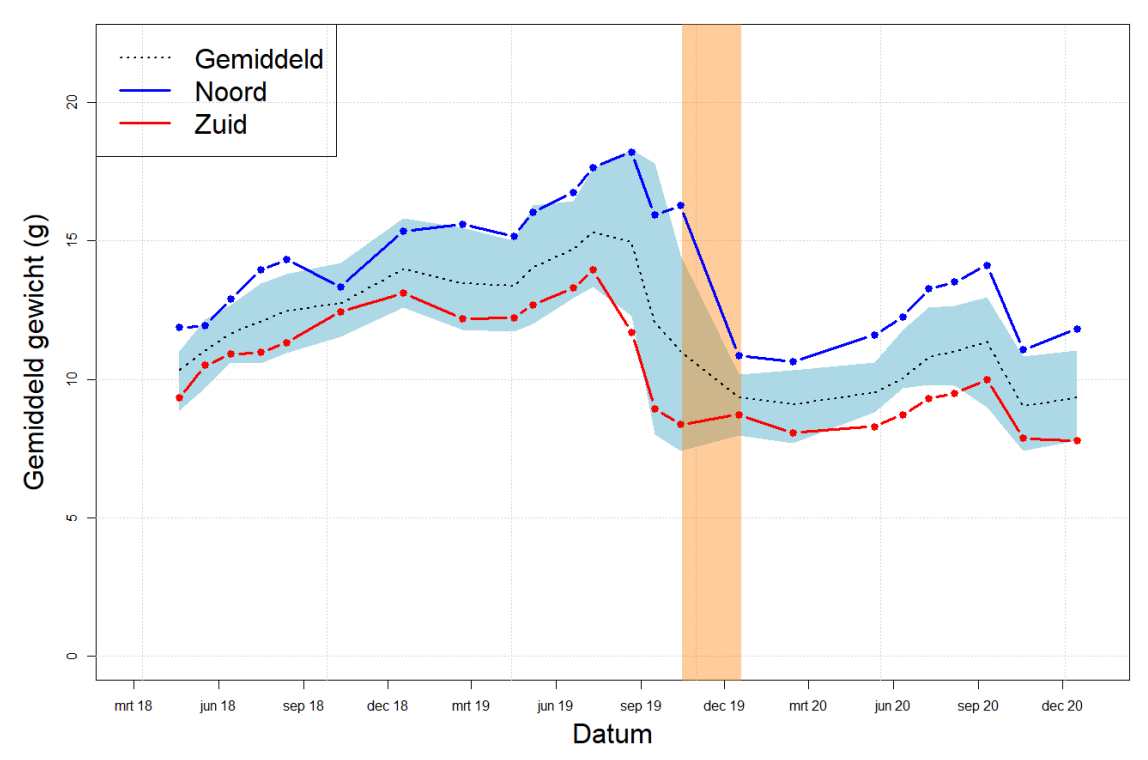

Figuur 8-10: Ontwikkeling van het gemiddelde gewicht van de mosselen op de percelen langs de Roggenplaat van 19 april 2018 tot en met 17 december 2020. Het lichtblauwe gebied geeft de bandbreedte waarbinnen $50 \%$ van de waarnemingen liggen en de zwarte stippellijn geeft het gemiddelde voor alle percelen. De periode waarin de suppleties zijn uitgevoerd is aangegeven met de oranje band. 


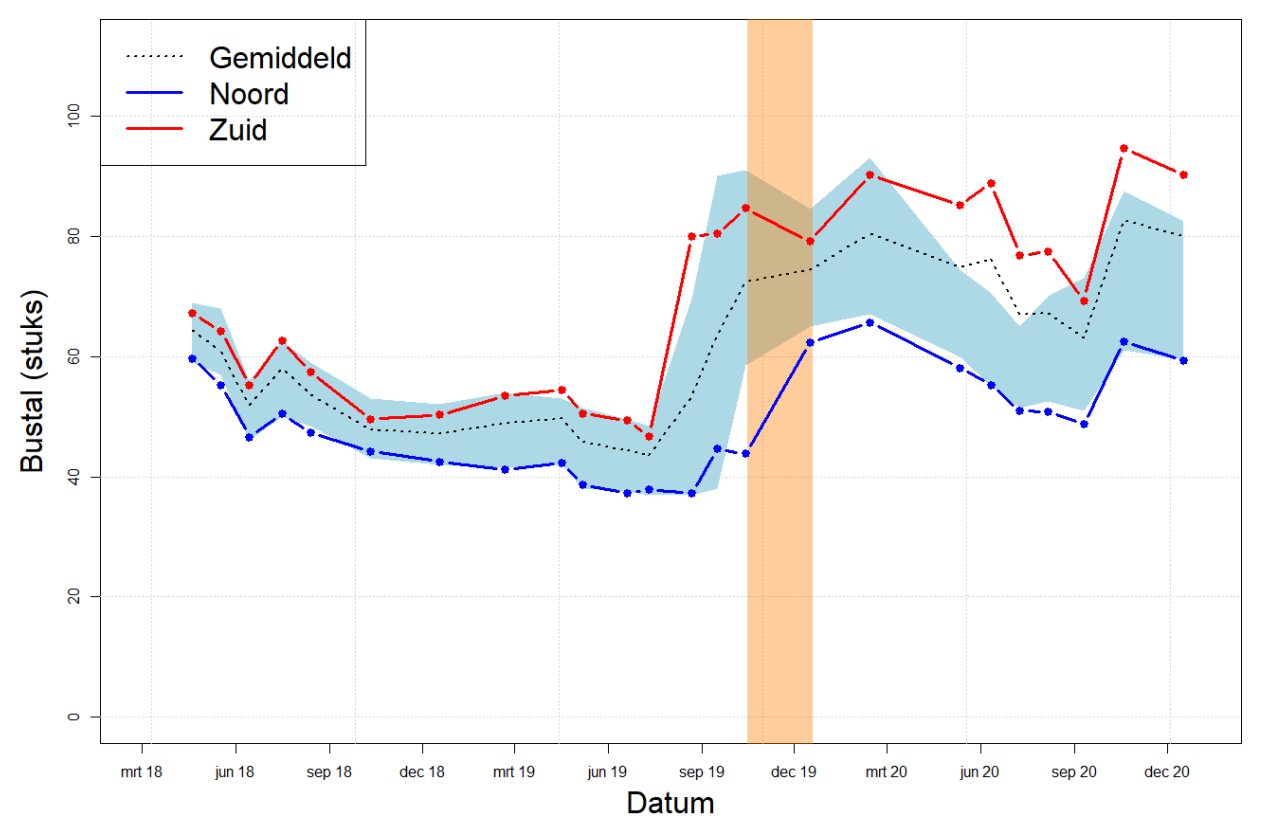

Figuur 8-11: Ontwikkeling van het bustal van de mosselen op de percelen langs de Roggenplaat van 19 april 2018 tot en met 17 december 2020. Het lichtblauwe gebied geeft de bandbreedte waarbinnen $50 \%$ van de waarnemingen liggen en de zwarte stippellijn geeft het gemiddelde voor alle percelen. De periode waarin de suppleties zijn uitgevoerd is aangegeven met de oranje band.

Peulen zijn de schelpresten van mosselen die recent zijn dood gegaan, waarbij de beide schelphelften met behulp van het slot nog aan elkaar zitten, en zijn daarmee een vroege indicatie voor sterfte. Soms zitten er zelfs nog wat vleesresten in de peulen. Tot de bemonstering van 17 april 2019 was het percentage peulen gemiddeld $1.5 \%$ (Figuur 8-12). Vanaf mei 2019 is het percentage toegenomen. Deze toename vond eerst op de percelen aan de zuidzijde plaats, met een piek in juni (gemiddeld bijna 14\% peulen) en daarna op de percelen aan de noordzijde van de Roggenplaat, met een piek in augustus. De sterfte van mosselen is in het voorjaar van 2019 op meerdere locaties in de Oosterschelde aangetroffen en heeft tot veel schade geleid voor de mosselkwekers. Het is nog niet duidelijk waardoor deze sterfte is veroorzaakt (Jansen et al., 2019). De sterfte op de percelen rond de Roggenplaats vond plaats ruim voordat is gestart met het aanbrengen van de suppleties. Ook tijdens de laatste bemonstering op 17 december 2020 was het gemiddelde percentage peulen aan de noordzijde relatief hoog $(10 \%$ peulen). Dit is echter het resultaat van het hoge percentage peulen (38.6 \% en $51.9 \%$ ) op één perceel dat vlak voor de bemonstering was leeggevist. Op de overige percelen aan de noordzijde was het percentage peulen op 17 december 2020 minder dan 4\%. 


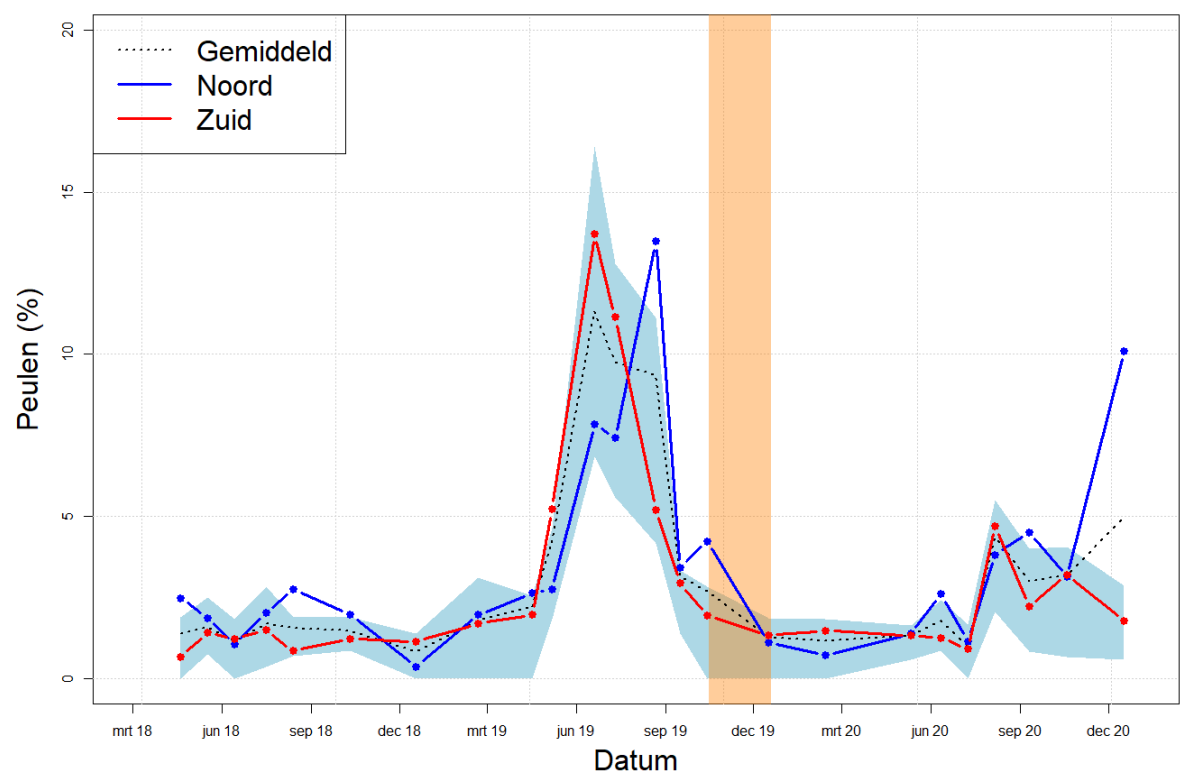

Figuur 8-12: Ontwikkeling van het percentage peulen op de percelen langs de Roggenplaat van 19 april 2018 tot en met 17 december 2020. Het lichtblauwe gebied geeft de bandbreedte waartussen $50 \%$ van de waarnemingen liggen en de zwarte stippellijn geeft het gemiddelde voor alle percelen. De periode waarin de suppleties zijn uitgevoerd is aangegeven met de oranje band.

Het vleespercentage is een maat voor de kwaliteit van de mosselen en is afhankelijk van de grootte van de mossel, de voedselsituatie en voortplanting. De bepaling van het vleespercentage zoals uitgevoerd tijdens deze bemonstering is niet identiek aan de bepaling die wordt uitgevoerd bij de mosselveiling, en dus niet één op één te vergelijken met Figuur 8-8. Omdat de methode binnen dit monitoringproject op een gestandaardiseerde wijze is uitgevoerd kunnen ze binnen het project wel met elkaar worden vergeleken. Het vleespercentage is niet tijdens iedere bemonstering gemeten (zie Figuur 8-9). Het gemiddelde vleespercentage over de hele periode was $21 \%$ (maximaal 30\% en minimaal 12.6\%) (Figuur 8-13). De laagste vleespercentages zijn aangetroffen in april 2019 (gemiddeld 14\%). Deze lage vleespercentages zijn mogelijk het gevolg van voortplanting. De mosselen aan de noordzijde van de Rottenplaat hebben (met uitzondering van april 2018 en mei 2020), een vleespercentage dat 1.4 tot 4.5 procentpunt hoger ligt dan de mosselen van de percelen aan de zuidzijde van de percelen. 


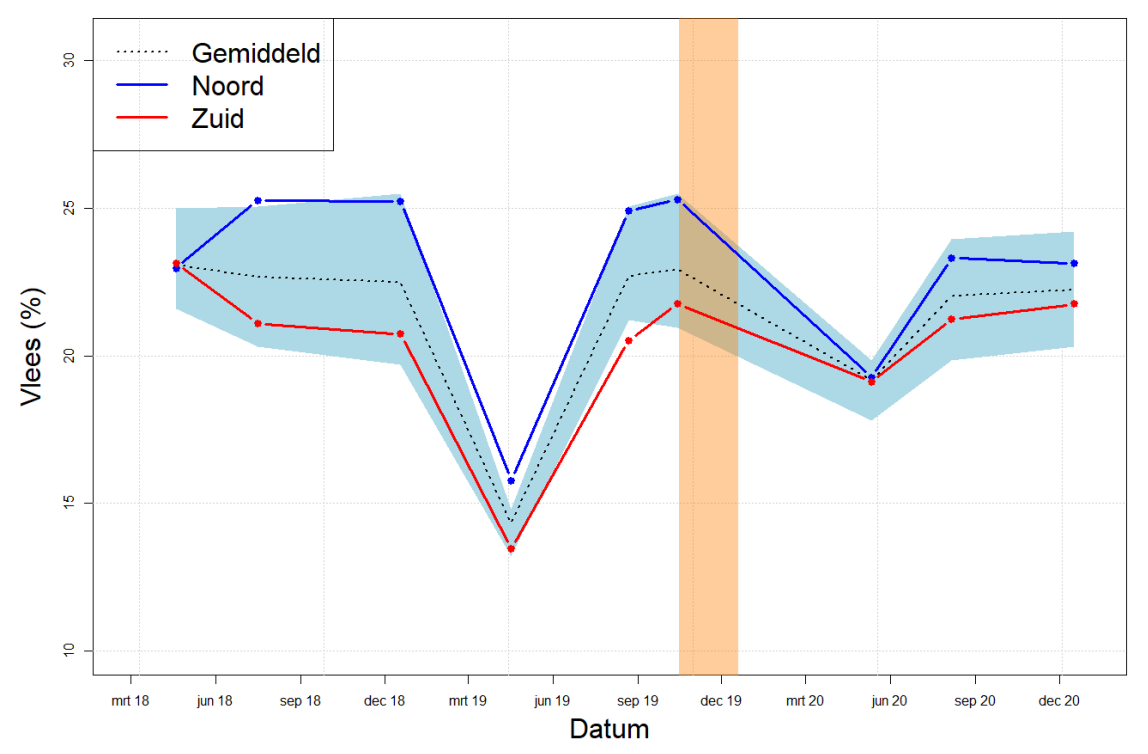

Figuur 8-13: Ontwikkeling van het vleespercentage van de mosselen op de percelen langs de Roggenplaat van 19 april 2018 tot en met 17 december 2020. Het lichtblauw gebied geeft de bandbreedte waartussen $50 \%$ van de waarnemingen liggen en de zwarte stippellijn geeft het gemiddelde voor alle percelen. De periode waarin de suppleties zijn uitgevoerd is aangegeven met de oranje band.

In de rapportages die zijn teruggekoppeld aan de kwekers wordt de ontwikkeling van de mosselen op hun percelen gerapporteerd en vergeleken met de geaggregeerde gegevens van de overige percelen. In Figuur 8-14 en Figuur 8-15 zijn hiervan een aantal voorbeelden gegeven voor een willekeurig perceel. 

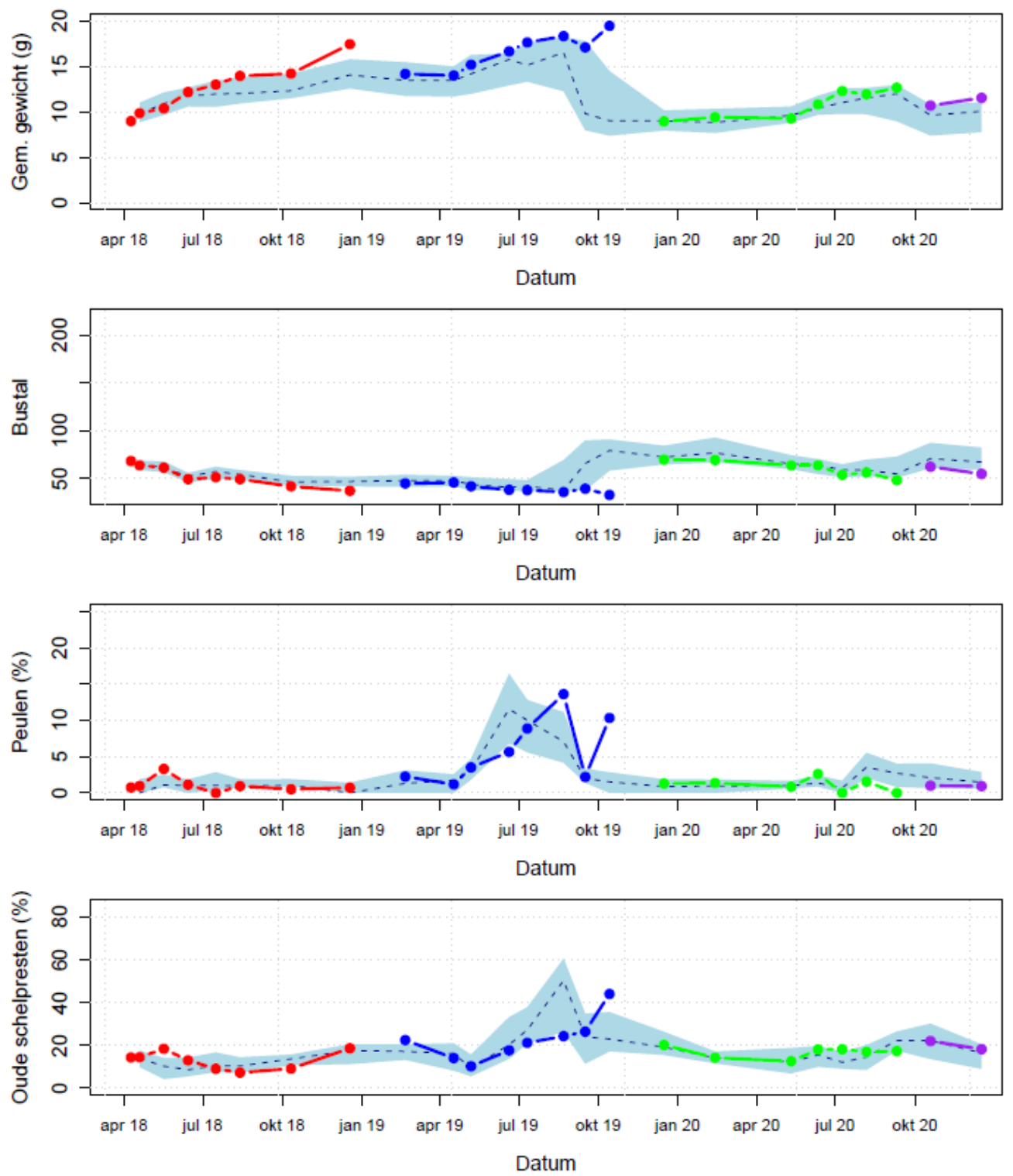

Figuur 8-14: Voorbeeld van een resultaat van de perceelbemonstering zoals die is teruggekoppeld naar een kweker. Het betreft hier de gemiddelde op alle bemonsterde percelen (licht blauwe vlak) en voor het betreffende perceel (punten) ontwikkeling van het gemiddeld gewicht, bustal, percentage peulen en percentage oude schelpresten. Met de verschillende kleuren worden verschillende cohorten op het betreffende perceel weergegeven. 

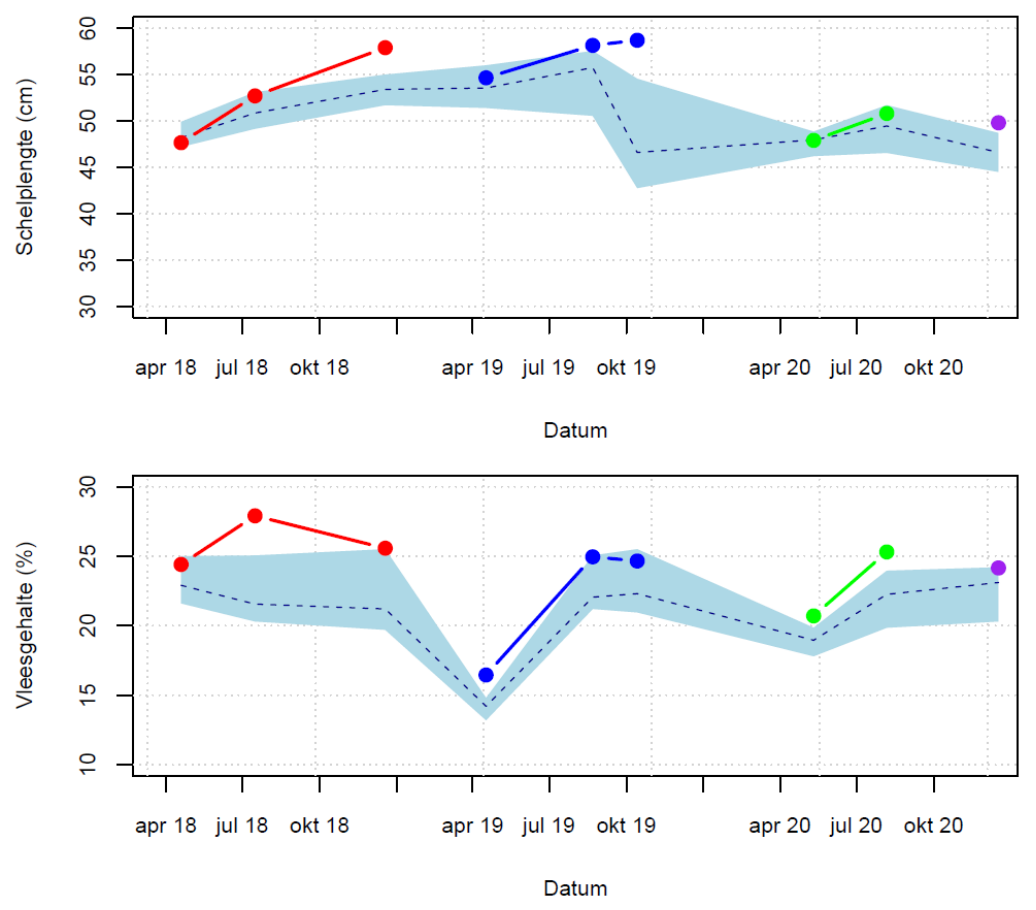

Figuur 8-15: Voorbeeld van een resultaat van de perceelbemonstering zoals die is teruggekoppeld naar een kweker. Het betreft hier de ontwikkeling van de gemiddelde schelplengte en het vleespercentage. Met de verschillende kleuren worden verschillende cohorten op het betreffende perceel weergegeven.

\subsection{Slib op de percelen}

\subsubsection{Methode}

De ondergrond van een perceel is een belangrijke factor voor de kwaliteit van een perceel. Gedurende de kweekcyclus verandert de ondergrond doordat de mosselen het slib dat ze invangen met hun kieuwen afzetten in de vorm van faeces en pseudofaeces. $\mathrm{Na}$ verloop van tijd wordt deze sliblaag steeds dikker. Voordat er nieuwe mosselen worden uitgezaaid op een perceel wordt het perceel vaak schoongevist waarbij deze sliblaag wordt omgewoeld en verwijderd.

Als er aanzanding plaatsvindt op een perceel kan dit effect hebben op de kwaliteit van het perceel en daarmee leiden tot schade voor de kweker. De ondergrond van de percelen langs de Roggenplaat bestaan voornamelijk uit relatief fijn materiaal. Het zand dat bij de suppletie wordt gebruikt is aanzienlijk grover. Het is te verwachten dat als het zand van de suppletie op de percelen terecht komt dit visueel dan wel via bemonstering, door middel van het wrijven tussen de vingers, is te onderscheiden. Door monsters te nemen van de bovenste decimeters van de bodem op en rond de percelen kan er een indruk worden verkregen van de bodemgesteldheid en kan er worden onderzocht of het zand van de suppletie is terug te vinden op de percelen. In totaal zijn er 7 bemonsteringen uitgevoerd. Er zijn twee bemonsteringen uitgevoerd voor de aanleg, een tijdens de aanleg en vier na de aanleg. In totaal zijn er tot op heden 188 steekbuizen genomen. Er worden tussen de 14 en 27 steekbuizen genomen verdeeld over de percelen 
rond de Roggenplaat (Figuur 8-17, linker figuur). Op 3 februari 2021 is er echter intensief (totaal 69 steekbuizen) bemonsterd op een drietal percelen aan de noordzijde van de Roggenplaat. Zie voor een uitgebreide methodebeschrijving Walles et al. (2021).

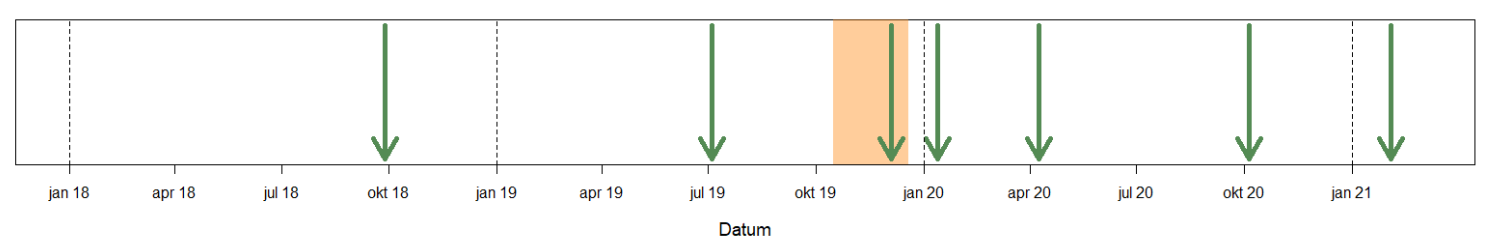

Figuur 8-16: Overzicht van de bemonsteringen met de steekbuis (groene pijlen). De periode van de aanleg van de suppleties is aangegeven door middel van de oranje band.
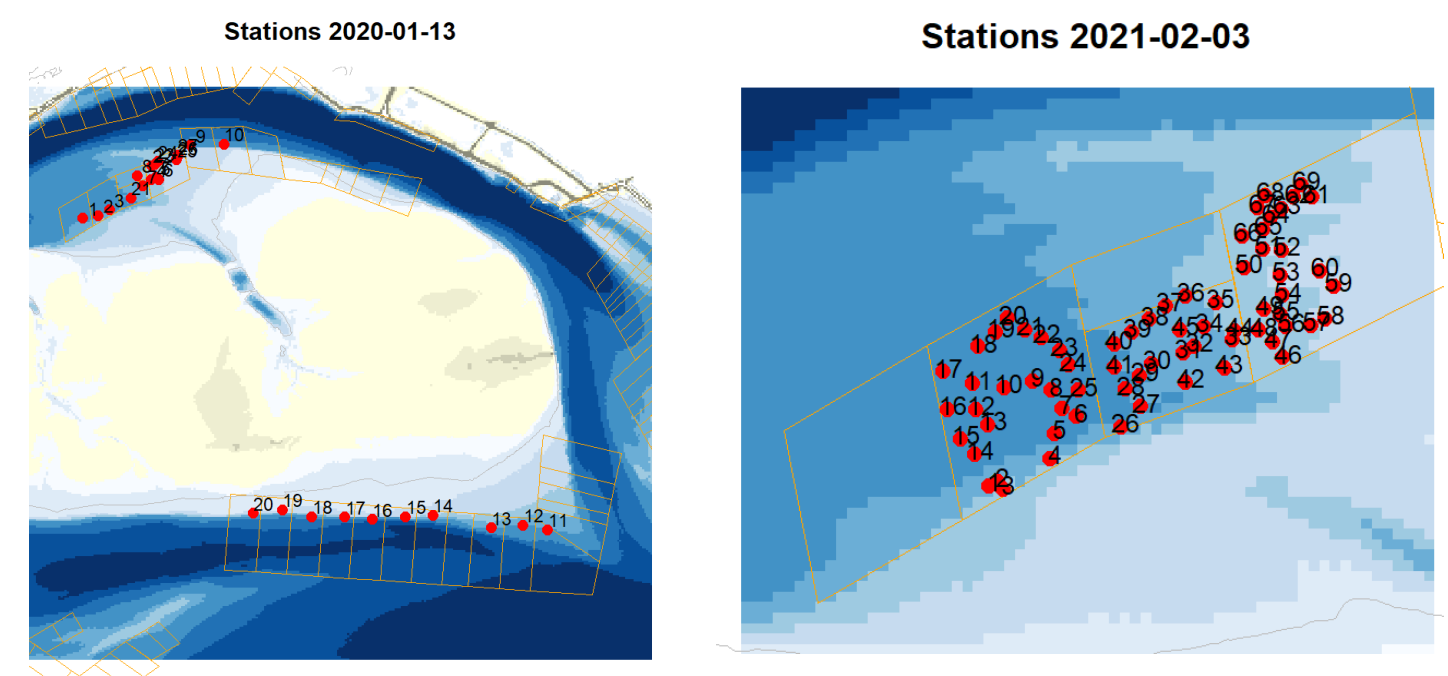

Figuur 8-17: Monsterlocaties met de steekbuis op 3 januari 2020 (links) en 3 februari 2021 (rechts), waarbij alleen intensief is bemonsterd op drie percelen aan de noordzijde van de Roggenplaat.

\subsubsection{Resultaten}

Op beide momenten zijn de percelen in het noorden slibrijker dan aan de zuidzijde van de Roggenplaat (Figuur 8-18). In het noorden is het voornamelijk slik met een beetje zand. Aan de zuidzijde is het voornamelijk zand met slik. 

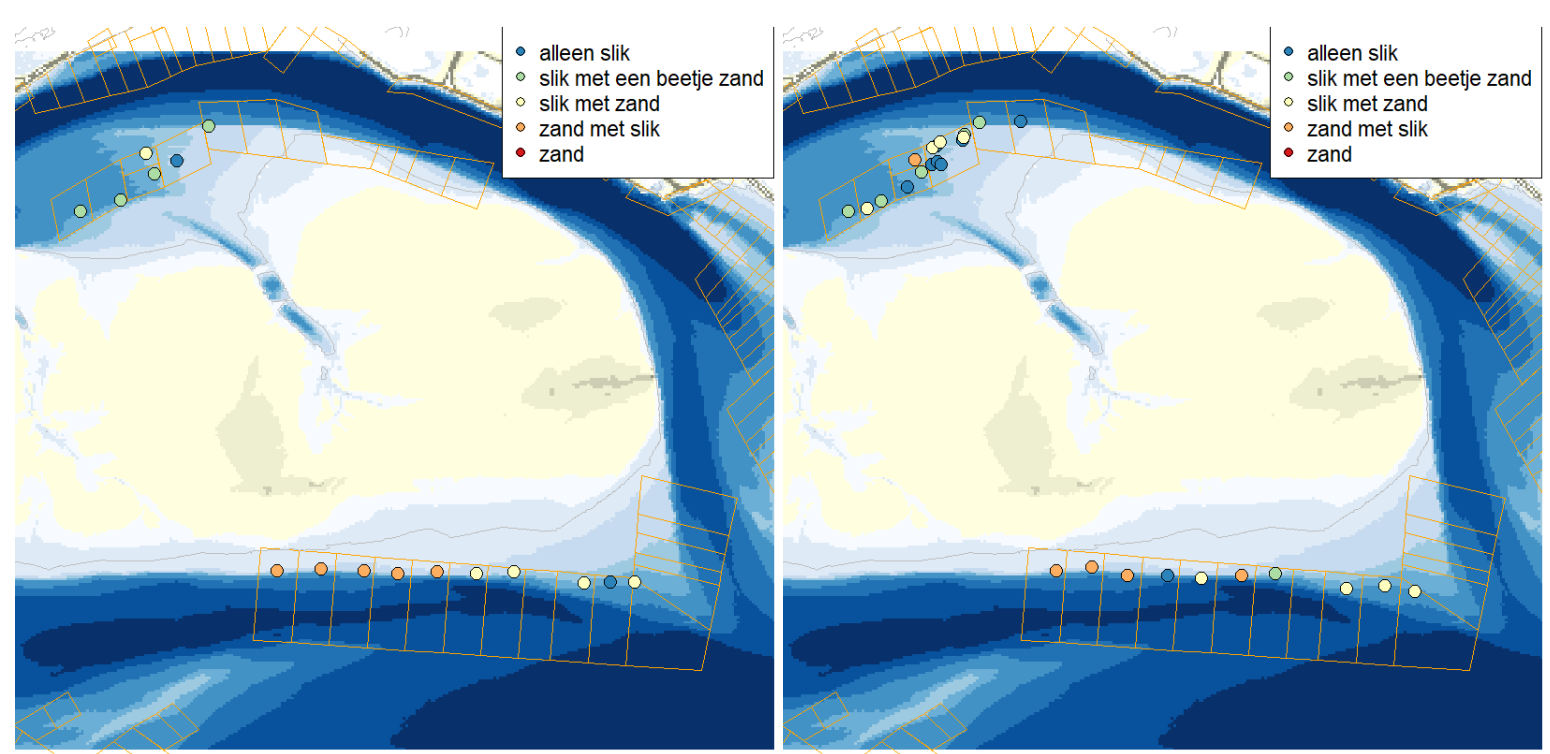

Figuur 8-18: Voorbeeld van de resultaten van de bemonstering met steekbuizen voor 27 september 2018 (links) en 13 januari 2020 (rechts).

De bemonstering op 3 februari 2021 is uitgevoerd omdat er een aantal kwekers die actief zijn aan de noordzijde van de Roggenplaat hadden aangegeven dat ze vermoedden dat er zand terecht was gekomen op hun percelen. Om dit te onderzoeken zijn er 114 steekbuizen genomen, waarvan 69 succesvol, verspreid over drie percelen, en geclassificeerd (Figuur 8-19). Ten tijde van de bemonstering was het meest westelijk perceel (Hammen 70) bezaaid, het middelste perceel (Hammen 69) was leeg en het oostelijk perceel (H68D) was bezaaid aan de zuidwestzijde. De noordzijde van dit perceel was leeggevist. In Figuur 8-19 is te zien dat het perceel H68D relatief zandig is aan de noordzijde. Ook was het daar niet eenvoudig om een goed monster te nemen vanwege de harde ondergrond (aangegeven met de kruisjes). Op het bezaaide deel aan de zuidzijde is over het algemeen meer slik aangetroffen. Ook op het leeggeviste perceel Hammen 69 was het niet eenvoudig om een goed monster te nemen. In de gevallen dat het wel lukte om een monster te nemen was het ook relatief slibrijk. De monsters op het bezaaide perceel H70 waren relatief slibrijk. Op 4 van de 25 bemonsterde locaties was het sediment relatief zandig. 


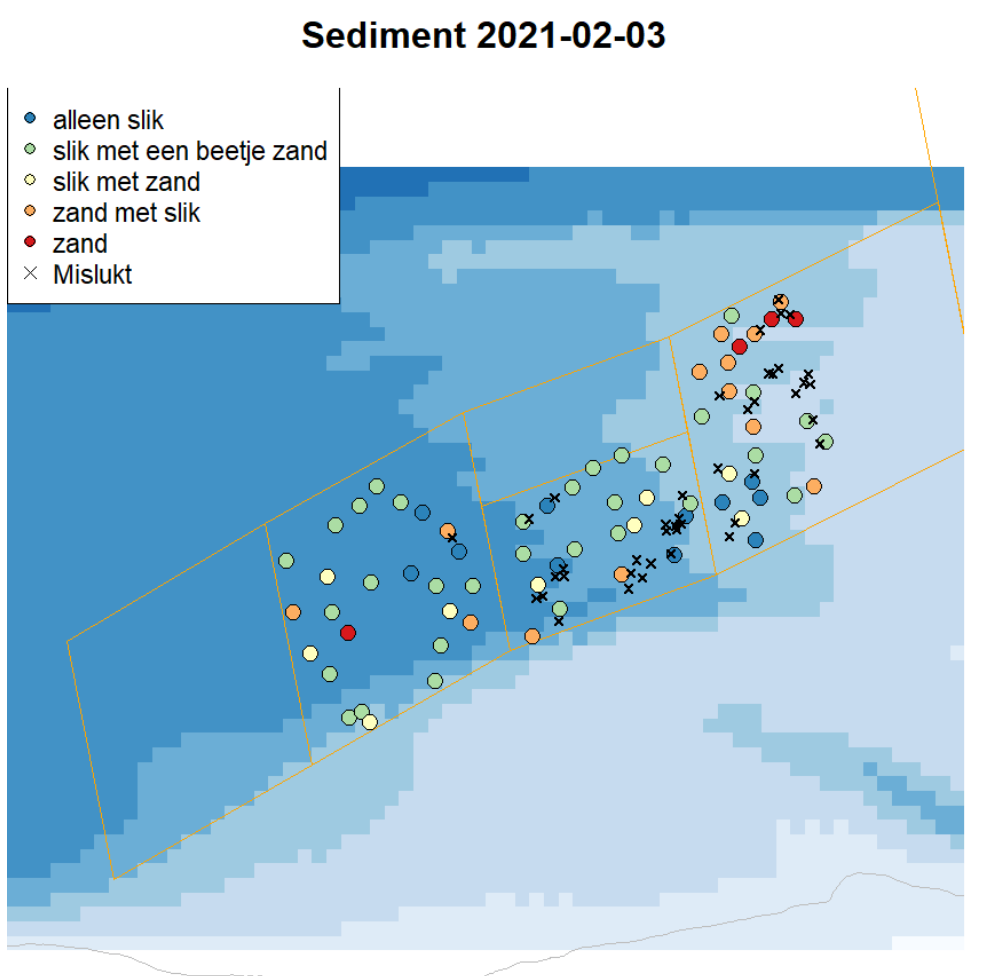

Figuur 8-19: Resultaten van de bemonstering met de steekbuizen op 3 februari 2021. Met behulp van de gekleurde bolletjes is de classificatie van het sediment weergegeven. Met de kruisjes is aangegeven waar het monster met de steekbuis is mislukt.

\subsection{Onderwateropnames}

Ook na de suppleties zijn bemonsteringen uitgevoerd met onderwateropnames op 8 april 2020. Methode en eerdere resultaten zijn te vinden in Walles et al. (2021). Echter waren de meeste beelden te slecht om geanalyseerd te worden en zijn de beelden niet gekwantificeerd. 


\section{Conclusies}

De situatie van de Roggenplaat vóór (tot en met 2019) en na aanleg (2020) van de suppleties is in dit rapport gepresenteerd op basis van data van de morfologie, hydrodynamica, sedimentkarakteristieken, benthische soortenverdeling, vogelverspreiding, en de kwaliteit van omliggende mosselpercelen. De monitoring op de Roggenplaat loopt nog door tot en met 2024. Het gaat hier dan ook om een tussentijdse evaluatierapportage.

\subsection{Veranderingen in de morfologie}

Het areaal droogvalduur is, vanwege de foerageerfunctie voor vogels, een centrale indicator voor het evalueren van de Roggenplaatsuppletie. De droogvalduur wordt bepaald door de morfologische ontwikkeling. Middels allerlei morfologische metingen is onderzocht welke processen ten grondslag liggen aan veranderingen in areaal droogvalduur, en hoe de suppletie-elementen de processen op de Roggenplaat beïnvloeden. Hieronder zijn de bevindingen samengevat met de nadruk op de impact van de suppleties.

\section{Bodemligging}

- De verandering net voor suppleren (tussen 2018 en 2019) zijn grotendeels in lijn met de trends sinds de aanleg van de Oosterscheldekering in 1986.

- Direct na aanleg bedekten de elementen 211 ha van de plaat, hadden een gemiddelde dikte per element van $30-80 \mathrm{~cm}$ en een maximale dikte tot $190 \mathrm{~cm}$.

- De zuidelijke suppletie-elementen 4, 5 en 7 (VOV) zijn de hoogste en steken tot $1 \mathrm{~m}$ boven NAP ( $80 \%$ droogvalduur) uit.

- Suppletie-elementen kunnen gegroepeerd worden naar aanlegdikte (dik/dun). Suppletie-elementen 1, 2, 3 en 6 bestaan uit een dunne suppletielaag en de wat hogere suppletie-elementen 4,5 en 7 uit een dikke suppletielaag.

- De zeven suppletie-elementen zijn 10 maanden na aanleg in hoogte afgenomen. Met name de zuidelijke suppletie-elementen 4, 5 en 7 liggen in de opname van oktober 2020 enkele tientallen centimeters lager. Ten noordoosten van element $1,4,5$ en 7 is sedimentatie zichtbaar, al lijkt dit minder dan de erosie van deze elementen.

- In hoeverre de suppletie-elementen lager liggen door erosie, zetting van de ondergrond en/of meetfouten wordt in het vervolg van het project onderzocht.

\section{Afwateringsgeulen}

Er zijn twee grote afwateringsgeulen: Middengeultje en Westgeultje. Alleen de morfologische veranderingen van het Middengeultje zijn opgevolgd.

- Het Middengeultje wordt vooralsnog niet substantieel beïnvloed door de aanwezigheid van de suppletie.

- De migratie van de zuidwestelijke geulwand van het Middengeultje in noordoostelijke richting zet door.

- Naast de suppletie-elementen is een aantal nieuwe afwateringsgeultjes gevormd met een diepte van enkele tientallen centimeters. 


\section{Droogvalduur}

- Door aanleg van de suppleties zijn de droogvalduurklassen;

- $\quad 50-80 \%$ zijn sterk toegenomen (met 130 ha)

- $40-50 \%$ sterk afgenomen

- Hiermee is het areaal $50-80 \%$ droogvalduur op de Roggenplaat weer terug op het niveau van rond 2001

\section{Sedimentsamenstelling}

- De suppletie-elementen bestaan voornamelijk uit middel fijn en grof zand (278 $\mu \mathrm{m}$ ). Dit is grover zand dan waar de Roggenplaat voornamelijk uit bestaat (209 $\mu \mathrm{m})$ (fijn zand).

- Het tussen de suppleties gelegen niet-gesuppleerde gebied laat in sedimentsamenstelling geen opvallende veranderingen zien als gevolg van de aanleg en de suppleties zelf.

\section{Stroom- en golfmetingen}

Deze metingen zijn nog niet volledig uitgevoerd en zullen in een latere rapportage verschijnen.

\subsection{Veranderingen in ecologie}

\section{Bentische macrofauna}

De draagkracht van een getijdenplaat voor steltlopers wordt primair bepaald door het voedselaanbod. De hoeveelheid geschikt voedsel dat aanwezig is, maar ook de grootte en de bereikbaarheid van de verschillende soorten bepalen de voorkomende vogelsoorten, de aantallen en de periode waarin ze van de plaat gebruik maken. De verzamelde bodemfaunadata vormen de basis voor het bepalen van de voedselbeschikbaarheid voor vogels, maar er is in deze rapportage is nog geen berekening gedaan voor de werkelijke beschikbaarheid voor vogels, rekening houdend met prooivoorkeur en diepte.

- In totaal kwamen 76 verschillende benthostaxa voor op de Roggenplaat na aanleg van de suppletie (gemiddeld 11 taxa per meetlocatie), vergelijkbaar met de situatie voor aanleg. De soortensamenstelling is niet veranderd in vergelijking met de situatie voor aanleg van de suppletie.

- De laagste dichtheid en soortenrijkdom bevindt zich op de zuidrand van de Roggenplaat en de lager gelegen delen rond de afwateringsgeulen. Dit is na aanleg van de suppleties onveranderd.

- Dichtheden en soortenrijkdom op de suppletie-elementen zijn duidelijk lager.

- Suppletiedikte is gerelateerd aan benthosdichtheden: op dikkere suppletieelementen worden significant lagere dichtheiden geobserveerd t.o.v. dunnere suppletie-elementen. Echter, het valt niet uit te sluiten of verschillen worden veroorzaakt door de ligging van de suppletie of de dikte van de aangebrachte suppletielaag, aangezien in het noorden van de Roggenplaat alleen dunne suppleties voorkomen. Ook kan meespelen dat de dikkere suppletie-elementen een hogere bodemligging hebben en dus langer droogvallen.

- Suppletie-elementen 4, 5 en 7 hebben een jaar na aanleg zowel de laagste soortendichtheid als soortenrijkdom na aanleg. Suppletie-elementen 2 en 6 hebben gemiddeld de hoogste soortendichtheid en suppletie-elementen 3 en 6 de hoogste soortenrijkdom. 
- De soortensamenstelling op de suppleties verschilt in samenstelling van de soortensamenstelling op de gehele Roggenplaat.

- Soortensamenstellingen verschillen tussen de verschillende suppleties. Hierbij is een verschil zichtbaar tussen dunne en dikke suppleties. Suppletie-element 7 bevat in vergelijking met de overige suppletie-elementen een andere soortensamenstelling.

- Tussen 2019 en 2020 is het aandeel van het totale kokkelbestand van de Oosterschelde op de Roggenplaat gedaald. Veranderingen in kokkelbestand zijn echter moeilijk te relateren aan de suppleties omdat slechts zeven (WOT) bemonsteringspunten zich binnen de suppletie bevinden. Op deze locaties werden voorheen jaarlijks kokkels aangetroffen, maar een jaar na aanleg vinden we alleen op het punt ten noorden van suppletie-element 4 kokkels.

\section{Oesterriffen}

- Tussen 2015 en 2019 was het areaal oesterriffen op de Roggenplaat vrij stabiel, variërend tussen de 58 en 63 hectare.

- Suppletie-elementen 2, 4 en 5 bedekken deels de nabijgelegen oesterriffen bij aanleg.

- Het areaal van de Roggenplaat bedekt met oesterriffen is met 6 ha afgenomen naar een totaal van 56 ha in 2020.

\section{Vogels}

Het uiteindelijke doel van de suppletie Roggenplaat is het in standhouden van voldoende foerageergebied voor steltlopers waarvoor de Oosterschelde van internationaal belang is. Om het effect van suppleties op het foerageergebied van de Roggenplaat te begrijpen, zijn laagwateraantallen, samenstelling en verspreiding van vogels voor en na de suppleties vergeleken.

- De suppletie lijkt in grote lijnen niet veel invloed te hebben gehad op aantallen, aantal soorten per dag en de soortsamenstelling van de meest frequente soorten.

- In telperiode 2 (2 tot 4 uur na hoogwater), is vogeldichtheid hoger op plekken waar de benthosdichtheid ook hoog is. Dit is het sterkst het geval in 2020.

- De hoogste aantallen vogels zijn over het algemeen te vinden op de oostkant van de Roggenplaat. Dit is het gebied waar de bodem iets slibrijker is en hoge dichtheden van 1- en 2- jarige kokkels voorkomen, die belangrijke prooisoorten zijn voor bepaalde vogelsoorten.

- Tijdens de suppleties foerageren veel zilvermeeuwen op het suppletiezand.

- Na de suppleties is de verspreiding over de Roggenplaat veranderd:

- Suppleties worden vermeden.

- Dichtheden op veel gebruikte plekken zijn hoger, mogelijk als effect van vermijden van suppleties.

- Vervolgonderzoek zal uitgevoerd worden naar de relatie tussen de verspreiding van specifieke vogelsoorten, droogvalduur en specifieke prooidieren. Tevens zal het gebruik van de suppletie door vogels in relatie tot het herstel van het bodemdierleven onderzocht worden.

\section{Zeehonden}

- In het Middengeultje en de Westgeul zijn de aantallen gewone zeehonden stabiel gebleven tussen 2015 en 2018.

- Er is geen duidelijke impact van de suppleties op de aantallen gewone zeehonden in de Westgeul.

- Aantallen in het Middengeultje laten een schommeling zien, vergelijkbaar met trends in de Voordelta. 
- De grijze zeehond is verdwenen in het Middengeultje sinds 2017 en in de Westgeul sinds 2018. In 2020 werd er weer één exemplaar geobserveerd.

\subsection{Proeven optimalisatie ecologisch herstel suppleties}

Middels het actief aanbrengen van een bodemdiergemeenschap op de suppletie werd getracht het toekomstige herstel en ontwikkeling te versnellen en in een gewenste richting te sturen (dat wil zeggen: de oorspronkelijke bodemdiergemeenschap herstellen), zodat de voedselfunctie voor vogels zo snel mogelijk na de ingreep weer op peil is. Hiervoor is geëxperimenteerd met het zogeheten "primen" middels het overbrengen van bodemleven en gebiedseigen sediment of het inzaaien van kokkels.

De conclusies zijn als volgt:

- Dit was de eerste priming van dit formaat.

- Het uitvoeren van een priming is geen 'common practice' en heeft tot technische uitdagingen geleidt die geresulteerd hebben in verschillen tussen de geprimede vakken.

- Eerste resultaten lijken een versnelde kolonisatie te tonen, echter zijn er op moment van rapportage te weinig monster uitgezocht om hier conclusie uit te trekken.

- Kokkels laten tussen inzaaien en 7 maanden na inzaaien een verlies in dichtheden zien van $70 \%$.

\subsection{Compensatie suppletie-element 7}

Suppletie-element 7 is aangelegd ter compensatie van significant negatieve effecten op het habitattype grote baaien ( $\mathrm{H} 1160)$, na bestorting van de vooroevers bij Burgsluis, Schelphoek en Zierikzee in 2014. Suppletie-element 7 behoort tot de hoogste suppletieelementen en steekt tot $1 \mathrm{~m}$ boven NAP uit. Deze suppletie is relatief klein in omvang vergeleken met de overige suppletie-elementen. Tussen februari en oktober 2020 vindt afname in gemiddelde dikte/hoogte plaats in de orde van $7 \mathrm{~cm}$, dit komt overeen met een volumeverlies van $11 \%$. Een afname in dikte/hoogte wordt ook voor zuidelijke elementen 4 en 5 geobserveerd, in tegenstelling tot het noordelijke suppletie-element 2 waar geen netto verandering is waargenomen. Tijdens de ontwerpfase is rekening gehouden met meer erosie door een grotere blootstelling aan golven voor de zuidelijke suppletie-elementen. Suppletie-element 7 bestaat voornamelijk uit middel fijn en grof zand. Slib en zeer fijn zand komt niet of nauwelijks voor op deze suppletie. Van alle suppletie-elementen bevat 7 de laagste soortenrijkdom en dichtheid. Een jaar na aanleg zijn de dominante soorten Nephtys cirrosa, Bathyporeia sarsi en Pygospio elegans. In voorgaande jaren werd $B$. sarsi alleen op hooggelegen locaties in het westen van de Roggenplaat gevonden waar het sediment geclassificeerd kan worden als middel fijn en grof zand. De soortensamenstelling geobserveerd op suppletie-element 7 wijkt een jaar na aanleg af van de overige suppleties. De oorzaak voor deze afwijking is onbekend. Voor aanleg van suppletie-element 7 behoorde het gebied tot de gebieden waar het meest frequent gefoerageerd werd 2 tot 4 uur na hoogwater. Na aanleg mijden vogels deze suppletie. Dit is in lijn met de overige gesuppleerde gebieden die gemeden worden door vogels. In de periode 4 tot 6 uur na hoogwater lijken vogels frequent op suppletieelement 7 te foerageren, in tegenstelling tot de andere suppletie-elementen Dit is mogelijks het resultaat van een intekenfout (pers. Communicatie tellers DPM). In het veld zien de tellers geen vogels foerageren binnen dit gebied. Ter ondersteuning voor 
het herkennen van deze suppletie worden extra palen aangebracht om de contouren te markeren. Verwacht wordt dat vogels de vogels de suppletie weer zullen gebruiken als foerageergebied zodra het bodemleven zich herstelt over de komende jaren.

\subsection{Voedselaanvoer Middengeultje}

Onderzocht is of het Middengeultje een belangrijke rol speelt in de voedselaanvoer voor de mosselpercelen die in de monding van dit geultje liggen. Hieruit zijn de volgende conclusie getrokken:

- Turbiditeit en chlorofyl laten een vast patroon zien binnen de getijdencyclus; beide pieken net voor hoogwater.

- Na de suppleties is het patroon is niet veranderd.

- Bentische en pelagische diatomeeën pieken bij de meeste meetpalen rond 1 uur na hoogwater. Rond de kentering komt het water tijdelijk stil te staan en kunnen algen neerslaan. Dit zou een toelevering van voedsel naar de mosselpercelen in de monding van het Middengeultje kunnen betekenen.

- In juni 2019 en mei 2020 bestaan diatomeeën voornamelijk uit pelagische soorten, in november half uit bentischs en half uit pelagische soorten.

- Pilot metingen met een sensorboot kunnen verschillen in troebelheid en chlorofyla aantonen in het oppervlaktewater. Ruimtelijke verschillen in troebelheid zijn gevonden met deze methode. Echter kan het verschil voor en na suppletie momenteel niet aangetoond worden door verschillende meetmomenten in het seizoen.

\subsection{Mosselpercelen}

Langs de randen van de Roggenplaat ligt een groot aantal percelen die door mosselkwekers worden gebruikt voor consumptiemosselen. De percelen in de monding van het Middengeultje en in mindere mate de percelen aan de zuidzijde van de Roggenplaat worden intensief gebruikt door mosselkwekers. Om te onderzoeken of het rendement van de percelen als gevolg van de suppleties verandert, is de kwaliteit van de mosselen onderzocht. Hieruit zijn de volgende conclusies getrokken:

- De mosselen aan de noordzijde van de Roggenplaat zijn relatief groot en hebben een gemiddeld hoger vleespercentage dan mosselen aan de zuidkant.

- De percelen in het noorden zijn slibrijker dan aan de zuidkant van de Roggenplaat.

- Sterfte van mosselen is, in het voorjaar van 2019, op meerdere locaties in de Oosterschelde aangetroffen en heeft tot veel schade geleid voor de mosselkwekers. Het is nog niet duidelijk waardoor deze sterfte is veroorzaakt (Jansen et al., 2019). De sterfte op de percelen rond de Roggenplaats vond plaats ruim voordat is gestart met het aanbrengen van de suppleties.

\subsection{Concluderend}

De dataset van de Roggenplaat geeft een grote verscheidenheid aan inzichten van de hydrodynamica, morfodynamica, bodemdieren, het gebruik van de Roggenplaat als foerageergebied en de ontwikkeling van de omliggende mosselpercelen. In deze rapportage zien we op een aantal onderdelen de invloed van de suppletie. Echter, de monitoring is op moment van rapportage nog in volle gang en al deze aspecten dienen nader en integraal onderzocht te worden op basis van een langere tijdreeks. Uiteindelijk 
kunnen de verkregen inzichten worden gebruikt bij het optimaliseren van toekomstige suppleties in intergetijdengebieden.

Wel kunnen we nu al concluderen dat de suppleties hebben geleid tot een verhoging van het areaal met een droogvalduur van $50-80 \%$. Hiermee is de eerste stap van het doel van het vergroten/herstellen van belangrijk foerageergebied voor vogels behaald. De suppleties zelf worden echter nog amper gebruikt door vogels een jaar na aanleg. Dit komt hoogstwaarschijnlijk door de vooralsnog lage dichtheden benthos op de suppleties. Met name de hoge suppletie-elementen hebben een lage benthosdichtheid. De verwachting is dat vogels de suppleties weer gaan gebruiken, zodra ook benthosdichtheden toenemen. Bij de Galgenplaatsuppletie duurde het een aantal jaren voor de bodemfauna hersteld was (van der Werf et al. 2011). Monitoring in de toekomst moet uitwijzen hoe benthos en vogeldichtheden zich gaan ontwikkelen, en of verschillen tussen de suppletie-elementen een rol spelen. 


\section{Kwaliteitsborging}

Wageningen Marine Research beschikt over een ISO 9001:2015 gecertificeerd kwaliteitsmanagementsysteem. Dit certificaat is geldig tot 15 december 2021. De organisatie is gecertificeerd sinds 27 februari 2001. De certificering is uitgevoerd door DNV GL. 


\section{Literatuur}

Arts, F., S. Lilipaly, R.C.W. Strucker (2016). Watervogels en zeezoogdieren in de Zoute Delta 2014 / 2015. RWS Centrale Informatievoorziening Rapport BM 16.09. 97 pages.

CBS, PBL, RIVM, WUR (2020). Gewone en grijze zeehond in Waddenzee en Deltagebied, 1960 - 2020. Gepubliceerd op Compendium voor de Leefomgeving

Coosen, J., F. Twisk, M.W.M. van der Tol, R.H.D. Lambeck, M.R. van Stralen, P.M. Meire (1994). Variability in stock assessment of cockles (Cerastoderma edule L.) in the Oosterschelde (in 1980-1990), in relation to environmental factors. Hydrobiologia: 282: 381-395.

De Mesel, I., C. Smit, J. Craeymeersch, J. Wijsman (2009). Evaluatie effectiviteit gesloten gebieden in de Oosterschelde, Westerschelde en Voordelta. IMARES Rapport C015/09.

De Ronde, J.G., J.P.M. Mulder, L.A. Van Duren, T.J.W. Ysebaert (2013). Eindadvies ANT Oosterschelde, Deltares rapport 1207722-000-ZKS-0010.

Desprez, M., H. Rybarczyk, J. G. Wilson, J. P. Ducrotoy, F. Seuer, R. Olivesi \& B. Elkaim (1992). Biological impact of eutrophication in the Bay of Somme and the induction and impact of anoxia. Netherlands Journal of Sea Research 30: 149-159.

De Vet, P. L. M., B.C. van Prooijen, R.A. Schrijvershof, J.J. van der Werf, T. Ysebaert, M.C. Schrijver, Z.B. Wang (2018). The importance of combined tidal and meteorological forces for the flow and sediment transport on intertidal shoals. Journal of Geophysical Research: Earth Surface, 123, 2464- 2480.

De Vlas, J., A. Brinkman, C. Buschbaum, N. Dankers, M. Herlyn, P. Kristensen, G. Millat, M. Ruth, J. Steenbergen, A. Wehrmann (2005). Intertidal Blue Mussel Beds. Trilateral Monitoring and Assessment Group. Common Wadden Sea Secretariat, Wilhelmshaven, Germany

Hu, Z., W. Lenting, D. van der Wal, T.J. Bouma. Continuous monitoring bed-level dynamics on a intertidal flat: introducing novel, stand-alone, high-resolution SEDsensors. Geomorphology 245: 223-230

Jansen, H., J.J. Capelle en M.Y. Engelsma (2019). Neoplasie in schelpdieren. Wat weten we? Een korte Q\&A. Wageningen Marine Research, Rapport, 3 pagina's.Rijkswaterstaat, 2015

Kesteloo, J.J. (2004). Het uitdunnen en verzaaien van kokkelbestanden met een hoge dichtheid in de Westerschelde in het najaar van 2020. RIVO rapport, 20 pagina's.

Kube, J. \& M. Powilleit (1997). Factors controlling the distribution of Marenzelleria cf. viridis, Pygospio elegans and Steblospio shrubsoli (Polychaeta: Spionidae) in the southern Baltic Sea, with special attention for the response to an event of hypoxia. Aquatic Ecology 31: 187-198. 
Lievense, P., M. Schrijver en E. Van Zanten (2016). Risico beoordeling van de Roggenplaat suppletie. Effecten van zandwinning en -suppletie op schelpdierpercelen. RWS Zee en Delta, Rapport, 42 pagina's.

Meire, P.M., J. Seys, J. Buijs, J. Coosen (1994). Spatial and temporal patterns of intertidal macrobenthic populations in the Oosterschelde: are they influence by the construction of the storm-surge barrier? Hydrobiologia 282/283: 157-182.

Seys, J.J., P.M. Meire, J. Coosen and J.A. Craeymeersch (1994). Long-term changes (1979-89) in the intertidal macrozoobenthos of the Oosterschelde estuary: are patterns in total density, biomass and diversity induced by the construction of the storm-surge barrier. Hydrobiologia 282/283: 251-264.

Sistermans W.C.H., M.A. Bergmeijer, E. Hartog, O.J.A. van Hoesel, M.M. Markusse, L. de Witte - Dek (2008). Het macrobenthos van de Roggenplaat in het najaar van 2008. Monitor Taskforce Publication Series 2008-13.

Troost, K., M. van Asch, E. Brummelhuis, D. van den Ende, J. Jol, J. Perdon, C. van Zweeden (2016). Handboek bestandsopnames schelpdieren WOT. Versie2, mei 2016. CVO rapport: 16.005 .

Troost, K., M. van Asch., E.B.M. Brummelhuis., D. van den Ende., J. Perdon., C. van Zweeden., J. van Zwol., J. v. d. Pool (2019). Handboek bestandsopnames schelpdieren WOT Versie 3, december 2019. CVO rapport: 18.013.

Van Asch, M., E.B.M. Brummelhuis, D. van den Ende, K. Troost, C. van Zweeden (2018). Het kokkelbestand in de Nederlandse kustwateren in 2018. CVO rapport: 18.011

Van den Berg, J.H. (1986). Aspects of sediment-and morphodynamics of subtidal deposits of the Oosterschelde (the Netherlands). PhD thesis. Technical University of Delft.

van de Werf, J., J. Reinders, A. van Rooijen, H. Holzhauer, T. Ysebaert (2011). Evaluation of a tidal flat sediment nourishment as estuarine management measure. Ocean and Coastal management 114: 77-87.

van der Werf, J., M. Boersema, A. Nolte, R. Schrijvershof, J. Stronkhorst, L. De Vet, B. Walles, T. Ysebaert (2016b). Definitief ontwerp Roggenplaat suppletie. Centre of Expertise Delta Technology, Deltares rapport 1220324-000-ZKS-0009.

van der Werf, J., M. Boersema, A. Nolte, R. Schrijvershof, J. Stronkhorst, L. De Vet, B. Walles, T. Ysebaert (2016a). Variantenstudie Roggenplaat suppletie. Centre of Expertise Delta Technology, Deltares rapport 1220324-000-ZKS-0008.

Van Zanten, E., L.A. Adriaanse, (2008). Verminderd getij. Verkenning naar mogelijke maatregelen om het verlies van platen, slikken en schorren in de Oosterschelde te beperken, Rijkswaterstaat rapport.

Van Zweeden, C., K. Troost, D. van den Ende, M. van Stralen (2011). Het areaal aan mosselbanken op de droogvallende platen in de waddenzee in het voorjaar van 2011. C097/12, IMARES. 
Walles B., S. van Donk, A. Hamer, J. Wijsman, T. Ysebaert, E. Ruranga, L. de Vet, J. van der Werf, A. Slager (2021). Roggenplaatsuppletie (Oosterschelde): ontwikkeling 2015 - 2019 (T0). C017/21, Wageningen Marine Research.

Wijnhoven, S., V. Escaravage (2008). Effecten van kokkelvisserij op de Slikken van de Dortsman (Oosterschelde): Bodemdier gemeenschappen en sediment karakteristieken voor en na het vissen en één jaar later. NIOO, Yerseke. NIOO-CEME rapport 2008, Monitor Taskforce Publication Series 2008-01. 51 pp.

Wijsman, J.W.M., J. Jol, J. Perdon (2010). Bepaling bestand op de mosselpercelen in de Waddenzee najaar 2009. Wageningen IMARES, Rapport nummer: C050/10, 50 pagina's.

Wijsman, J.W.M. (2017). Poweranalyse van de vleespercentages van mosselen aan de veiling. Onderzoek naar de mogelijkheden om eventuele effecten van de Roggenplaatsuppletie op de mosselkweek aan te tonen aan de hand van de veilingdata. Wageningen Marine Research, Rapport nummer: C114/17, 34 pagina's.

Wijsman, J.W.M., M. Kraan (2017). Plan van aanpak risicomonitoring Roggenplaatsuppletie; Monitoring effecten op de nabijgelegen mosselkweekpercelen. Wageningen Marine Research, Rapport nummer: C037.17, 51 pagina's.

Witteveen en Bos (2011). MIRT-Verkenning Zandhonger Oosterschelde. Ontwerpstructuurvisie, Witteveen+Bos rapport RW1809-28/torm/231.

Ysebaert, T., J. van der Werf, M. Boersema, R. Schrijvershof, J. Stronkhorst, L. de Vet, A.O. Debrot, T. Bouma (2016). T0-rapportage Roggenplaat suppletie. Centre of Expertise Delta Technology, Imares rapport.

Ysebaert, T., J. van der Werf, L. de Vet, T. Bouma (2017). Monitoringsplan Roggenplaat suppletie. Centre of Expertise Delta Technology, Wageningen Marine Research rapport.

Zandvoort, M., E. van der Zee, V. Vuik (2019). De effecten van Zeespiegelstijging en Zandhonger op de Oosterschelde. Eindrapport van de studie EZZO: Tauw BV, Altenburg \& Wymenga en HKV Lijn in Water. I.o.v. Rijkswaterstaat Zee en Delta. Utrecht / Middelburg.

Zwarts, L., A-M. Blomert, D. Bos, M. Sikkema (2011). Exploitation of intertidal flats in the Oosterschelde by estuarine birds, A\&W rapport 1657 Altenburg \& Wymenga ecologisch onderzoek, Feanwâlden 


\section{Verantwoording}

Rapport C038/21

Projectnummer: 4313100081

Dit rapport is met grote zorgvuldigheid tot stand gekomen. De wetenschappelijke kwaliteit is intern getoetst door een collega-onderzoeker en het verantwoordelijk lid van het managementteam van Wageningen Marine Research

Akkoord: $\quad$ Dr. I.Y.M. Tulp

Onderzoeker

Handtekening:

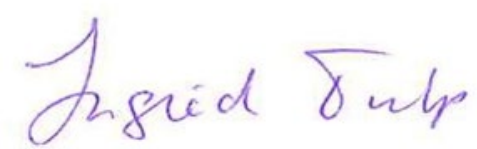

Datum:

6 april 2021

Akkoord: Drs. J. Asjes

Manager integratie

Handtekening:

Datum:

6 april 2021 


\section{Bijlage 1 Memo Boskalis: Toelichting Priming suppletievak 2}

\section{riz \\ Boskalis}

Datum

15-10-2019

Kenmerk

ROG-MEMPRIMING

Pagina

$1 \mid 6$
Aan

Boskalis EA

Kopis

\section{MEMO}

\section{Toelichting Priming suppletievak 2}

Ervaringen bij het primen op Roggenplaat

Bij de suppletie Roggenplaat is gekozen om binnen suppletie vak 2 drie vakken te primen met droog grondverzet. De afmetingen per vak zijn $50 \times 100$ meter en de prime vakken liggen aan de noordzijde van het suppletie vak. Er is nog weinig ervaring met deze wijze van primen in getijdegebieden in Nederland en een geschikte techniek kon niet op voorhand gegeven worden. Deze memo geeft de ervaringen en inzichten weer van het primen van 3 vakken van 0,5 hectare.

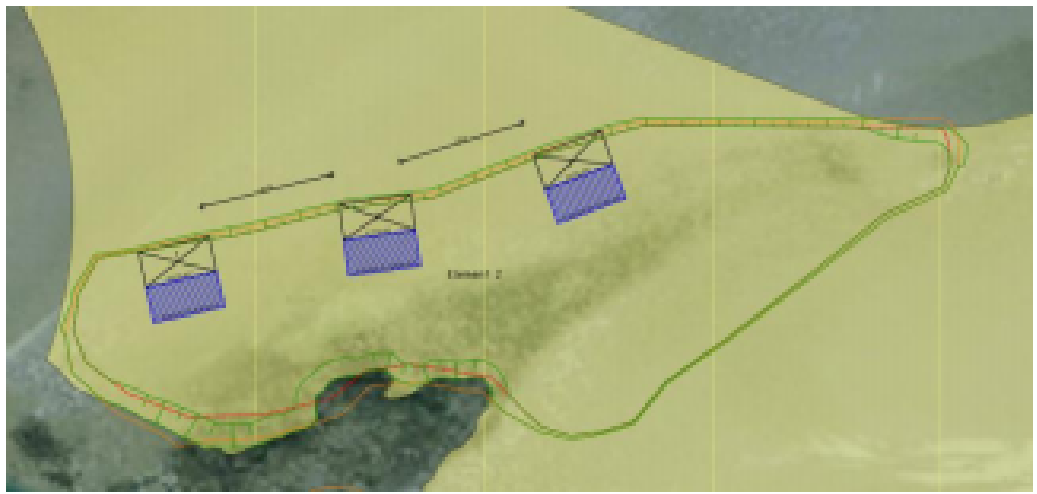

De bedoeling van primen is het overbrengen van bodemleven en intacte bodem, zodat het bodemleven kan continueren en versneld kan herstellen ten opzichte van nieuw gesuppleerd zand waarin nog geen bodemleven aanwezig is. Een versnelde terugkeer of herstel van bodemleven kan de voedselfunctie voor vogels weer op peil brengen, zo snel mogelijk na de ingreep.

De doelstelling is om $22 \mathrm{~cm}$ toplaag met een kraan uit te graven en deze toplaag zo intact mogelijk op de oude bodem te leggen, zodat de primelaag even dik wordt als de suppletie laag rondom. Zo blijft de oppervlakte bestaan uit oude bodem.

Op 5 oktober is begonnen met het primen van het meest oostelijke vak. De kraan snijdtsteekt gelijk op $22 \mathrm{~cm}$ en graaft deze laag in 1 keer af. Vervolgens wordt deze grond op een rug gelegd, waarna de shovel deze oppakt en naar het primevak brengt. Het afgraaf vak en primevak lagen aanvankelijk aan elkaar. Voor de shovel bleek het niet werkbaar om steeds rond het gebied te rijden, maar om het zand rechtstreeks naar het primevak te 


\section{rir \\ Boskalis}

MEMO

brengen. De shovel rijdt zodoende over de af te graven bodem en verstoort het bodemleven. Besloten is dat de kraan vervolgens zijwaarts blijt graven en alleen intacte bodem op ruggen legt. De shovel legt deze behoedzaam in het primevak, door geleidelijk achteruit te rijden en het zand uit de bak te laten glijden. Het zand komt zodoende min of meer op ruggen te liggen.

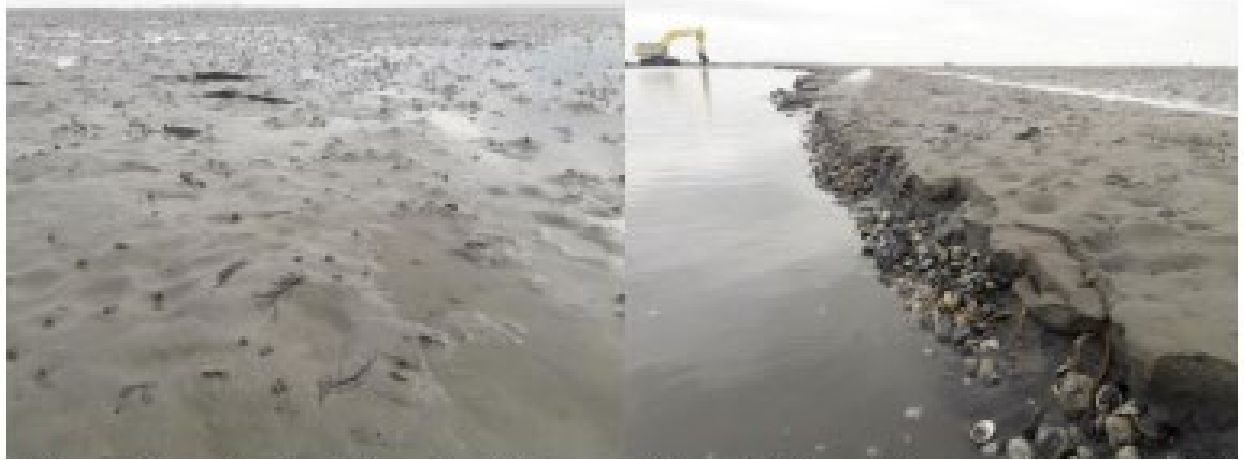

Originele bodem en structuur toplaag: clirca $10-15 \mathrm{~cm}$ zand met een slibrijke onderlaag van zand en lege (kokkel)schelpen.

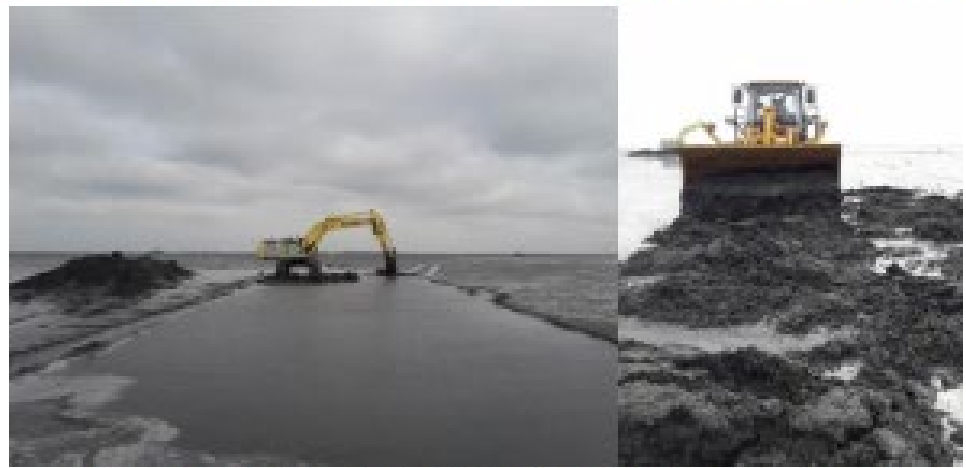

De toplasg worde esn esn rug gelegd, waama do shovel deze urspreidt op hot primevak.

Het bleek niet mogelijk om de bovenkant toplaag als bovenkant in het primevak te krijgen. De afgegraven laag komt gemengd te liggen. Een eerste visuele inspectie liet zien dat wormen hier beschadigd door kunnen raken. Een deel bleek na 2 dagen nog levend, omdat er faeceshoopjes te zien waren. Op deze wijze kwam er een laag zand in het primevak die de gewenste dikte redelijk benaderde. De zandhopen vlakten geleidelijk af na enkele getijden.

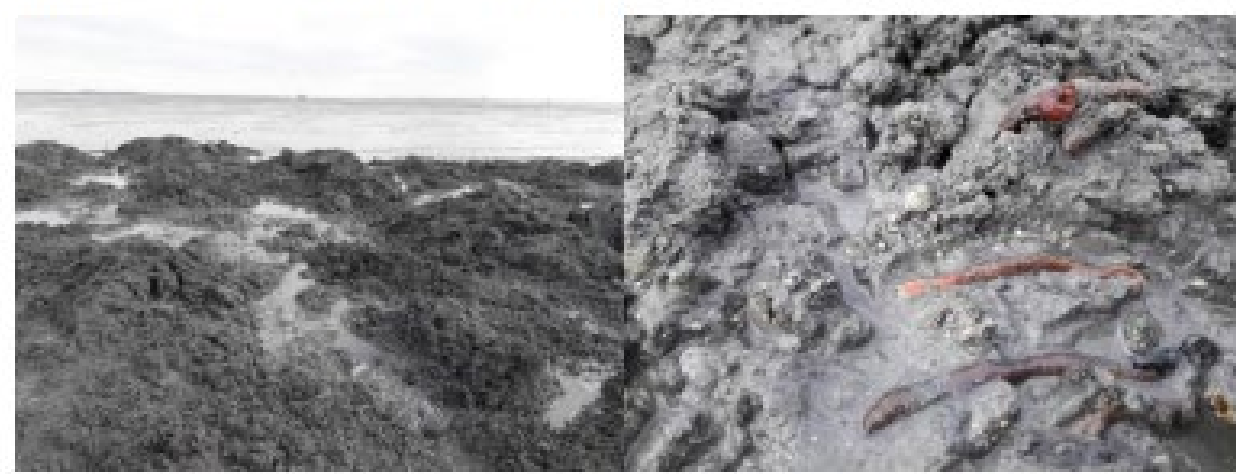




\section{riv}

\section{Boskalis}

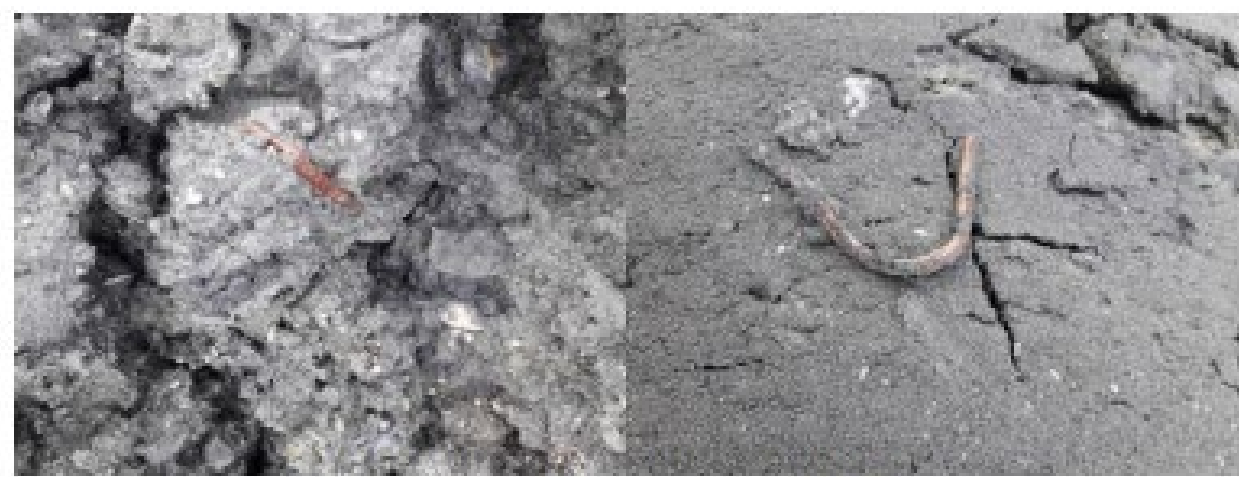

Prime laag direct na aanbrengen, met sporen van bodemieven.

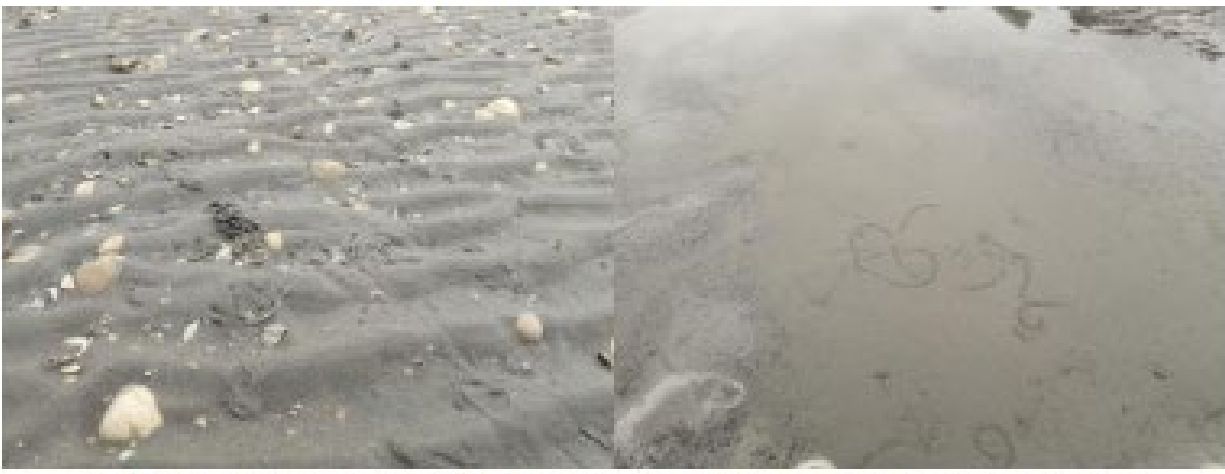

Primelaag vak 3, na een enkel getij, met fasceshoopjes van wadpieren en sporen van wadslakjes. Ook vogels hebben het primevak ontdekt. 


\section{rir \\ Boskalis}

MEMO

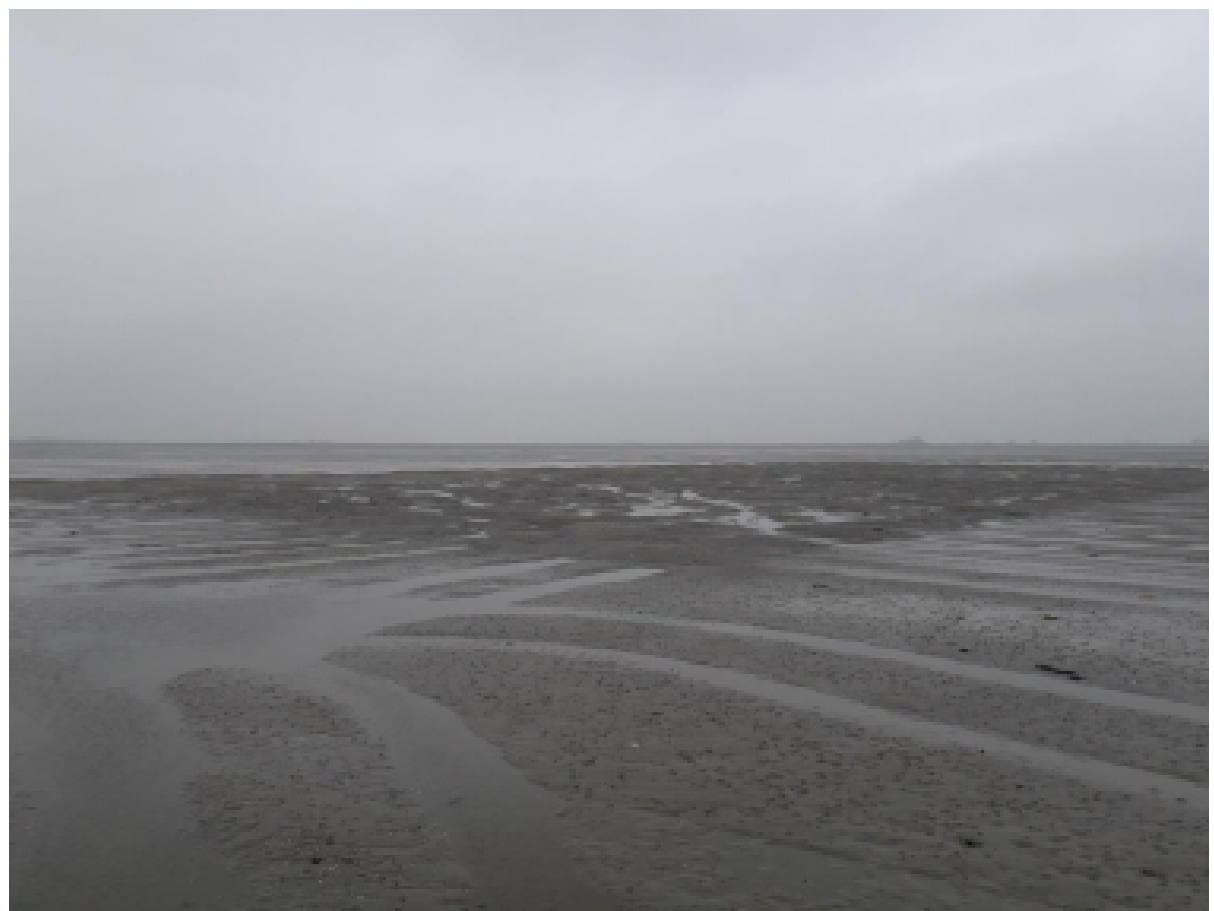

Primevak 3 na aanberengen en enkele getijden. Te zien zijn ook de sporen van de showel naar hot primevak toe.

In vak 2 bleek de bodem veel slapper, waar in vak 3 de bodem redelijk bleef dragen, trok de shovel gelijk sporen. Door per keer een halve laadbak mee te nemen kwam er minder primelaag in vak 2. Door de spoorvorming van de shovel raakte de onderlaag zodanig verstoord dat deze werkwijze niet lang werkbaar was. Besloten is dat de kraan het zand op rug zet en deze vervolgens in 1,2 of 3 keer verplaatst naar het primevak. De afweging was dat dan het bodemleven wel meer verstoord wordt, maar dat er wel een originele bodemlaag wordt aangebracht. De dikte van de pimelaag in vak 2 is minder geworden dan in vak 3. Na een enkele getijdeslag zag de toplaag er redelijk uit. 


\section{rin \\ Boskalis}

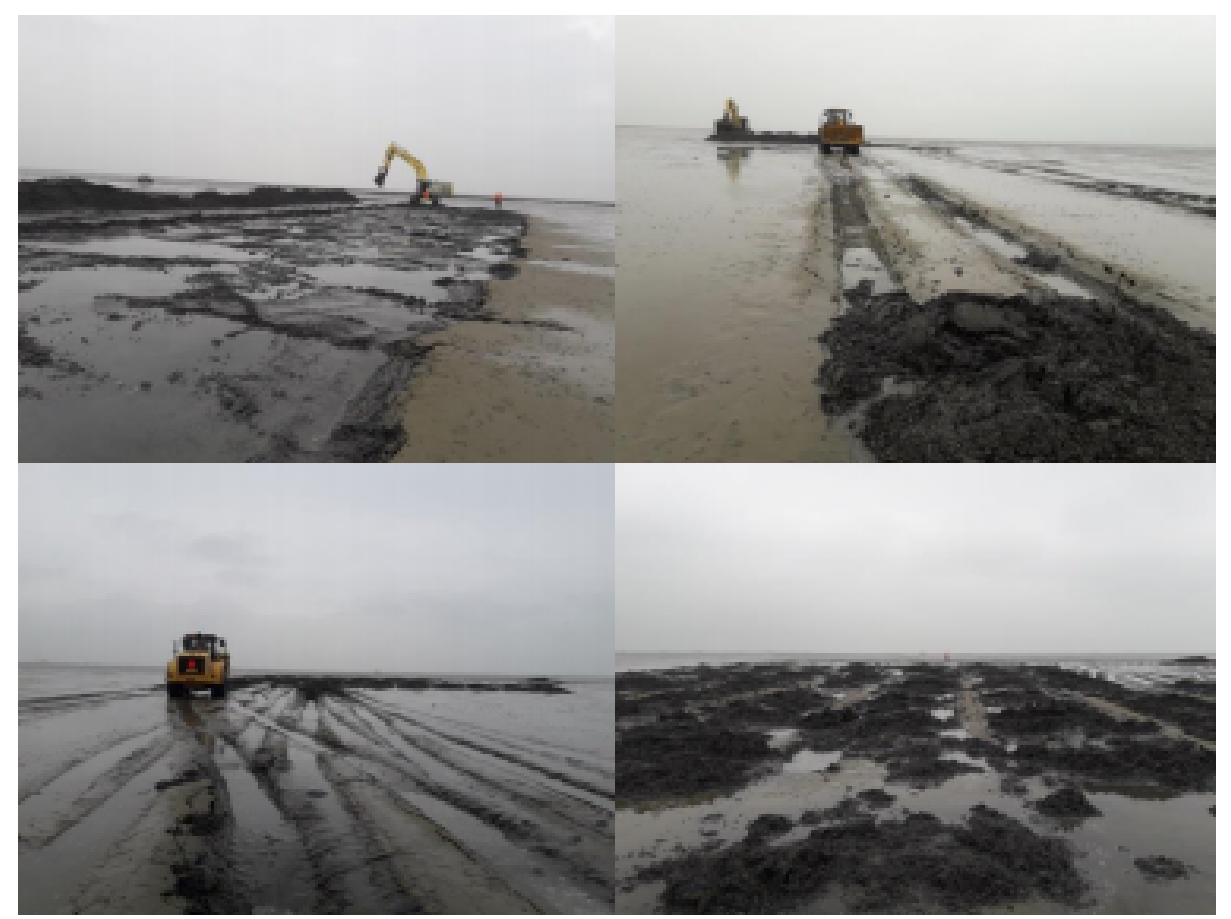

Priming vak 2, op slappe bodvm. Aanvankelijk was de primelaag minder dik, omdat de shovel halve laadbakken gebruikte.

Later is dit door do kraan aangevuld.

Tijdens werkoverleg is gediscussieerd over hoe vak 1 kan worden geprimed, omdat de verwachting was dat door de nabije ligging van de geul de bodem ook slap zou zijn. Besloten is om aanvankelijk alleen met de kraan te werken, die het via ruggen over het primevak zou aanbrengen. De bodem bleek iets vaster te zijn, waardoor ook de shovel is ingezet. Na aanbrengen zag de primelaag er egaler uit dan in vak 3, wat komt door inzet van de kraan. De priming is afgerond op 10 oktober.

Algemene indruk van het aanbrengen van een primelaag:

- Het is mogelijk een primelaag aan te brengen, alleen wordt deze door de kraan en shovel wel gemengd aangebracht. Het overbrengen van een intacte laag is vrijwel niet mogelijk.

- Bij voldoende vaste bodem kan de combinatie kraan-shovel gebruikt worden. Bij te slappe bodem alleen de kraan die de prime laag via ruggen omzet.

- $\quad \mathrm{r}$ is overleving van bodemleven geconstateerd, van wormen en schelpdieren.

- Het reliëf dat door de kraan en shovel ontstaat, is gunstig omdat er zo water blijtt staan. Hierdoor kan bodemleven zich gevarieerd ontwikkelen en kunnen vogels er langer voedsel zoeken dan bij een vakke bodem. Het reliëf zal naar verwachting afnemen in de tijd en het zal blijken of dit blijft bestaan.

Aandachtspunten bij toekomstig primen:

- Er kan gewerkt worden met een kraan met lange giek (25 meter), zodat de primelaag in 1 bewerking wordt aangebracht. Dit kan minder verstoring van de primelaag geven. Wanneer alles met een kraan met een lange giek wordt gedaan, is het de moeite waarde om de vorm van het primingvak te optimaliseren voor de reikwijdte van de kraan.

- Verplaatsen met een bulldozer biedt mogelijkheden is de indruk. Een bulldozerl schuift de laag in 1 keer naar het primevak, waarna de kraan het kan verdelen. Dit kan eens uitgeprobeerd worden. 


\section{ri⿱}

\section{Boskalis}

- Met het oog op mogelijke priming op grote schaal is het interessant om te onderzoeken wat de effectiviteit is van priming door middel van diep ploegen. Deze methode houdt in dat na de suppletie de oorspronkelijke bodem naar boven wordt gehaald met een diepploeg. De haalbaarheid is afhankelijk van de aan te brengen laagdikte. Over de mate van overleving van het bodemleven bij diepploegen is niets bekend. Het zal wel snel na de suppletie moeten gebeuren, omdat het bodemleven hooguit een enkele dag begraven kan overleven. Mocht deze methode effectief zijn, dan zou deze toegepast kunnen worden voor priming van grote oppervlaktes.

- Het aanpassen van de vorm van primingvakken kan ook interessante varianten opleveren. Een voorbeeld is het verwijderen van benthos uit het midden van een suppletieelement, om dit vervolgens aan de randen van de suppletie uit te spreiden. Zo ontstaat een soort kom met daaromheen kaaien. Deze kom kan vervolgens gesuppleerd worden met nieuw materiaal om het hele element op hoogte te brengen. 


\section{Bijlage 2 Hoogte in $\mathrm{cm}$ NAP per droogvalduurklassen}

iin Boskalis

Datum

18-11-2019

Kenmerk

ROG-MEMPRIMING.

KOKOKELS

Aan

Boskalis EA

Kopis
Van

Marco Dubbeldam

Pagina

$1 \mid 10$

MEMO

Toelichting Priming Kokkels Suppletievak 2

Ervaringen bij het primen van kokkels op Roggenplaat

Bij de suppletie Roggenplaat is gebruik gemaakt van 'priming', het verplaatsen van de originele bodem en/of bodemfauna zodat deze in de toplaag aanwezig blijven. Het bodemleven dat de verplaatsing overleeft en de kenmerken van de originele bodem zorgen naar verwachting voor een versnelde terugkeer van de bodemdiergemeenschap ten opzichte van het gesuppleerde zand, dat nog geen bodemleven kent.

Bij de suppletie Roggenplaat is gekozen om binnen suppletie vak 2 drie vakken te primen met droog grondverzet. De afmetingen per vak zijn 50x100 meter en de primevakken liggen aan de noordzijde van het suppletie vak. De ervaringen met droog grondverzet zijn in een eerdere memo verwoord. Naast droog grondverzet is gekozen om ook priming van kokkels toe te passen. Deze memo geeft de ervaringen en inzichten weer van het primen van 2 vakken van 0,5 hectare. De vakken zijn genummerd 1 en 2 van links naar rechts en liggen ten zuiden van de vakken met droog grondverzet.

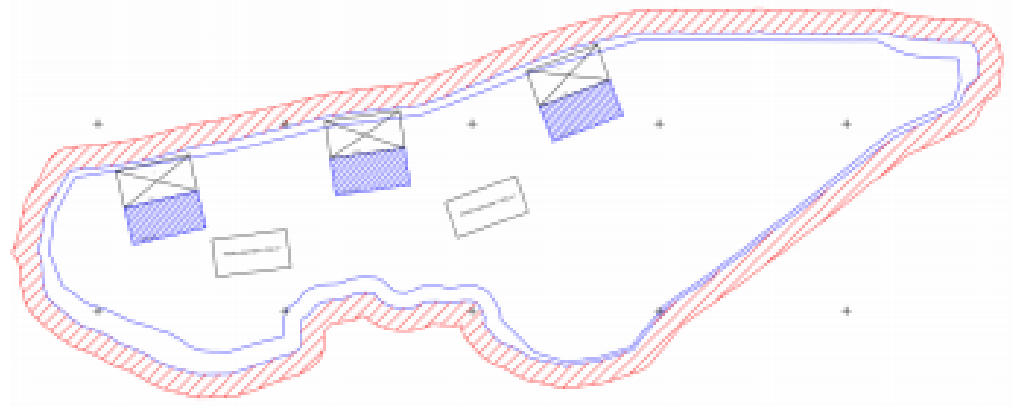

Suppletie element 2 met aan de noordkant 3 primevakken met droog grondverzet (uit de blauwe vakken) en 2 primevakken met verzaside kokkels op gesuppleerd zand.

Net als bij de vakken met droog grondverzet is het bij het primen met kokkels de bedoeling om het vak versneld weer aantrekkelijk te maken als voedselgebied voor vogels. Een vak van minimaal 50*50 meter en een dichtheid aan (meerjarige) kokkels van minimaal $0,9 \mathrm{~kg}$ versgewicht per vierkante meter begint relevant te worden als voedselzoekgebied voor steltlopers, zoals scholeksters. De coordinaten van de kokkelprimevakken zijn door WMR aangeleverd en surveyors van Boskalis hebben deze punten op de plaat gemarkeerd met boeitjes. Het streven was om 10 ton kokkels te vissen en te verzaaien. 
De uitgangspunten bij het primen met kokkels zijn dat deze uit de te suppleren vakken gevist worden en daarna op een reeds gesuppleerd vak weer verzaaid worden. De kokkels uit de te suppleren vakken overleven een nieuwe zandlaag van minimaal $30 \mathrm{~cm}$ naar alle waarschijnlijkheid niet en dragen niet meer bij aan de voedselreservering voor de vogels en eventuele reservering voor visserij.

Op 5 juli is een eerste globale inventarisatie geweest naar de aanwezigheid van kokkels in de suppletievakken $2,3,5$ en 6 . In vak 2 en 3 bleken tot enkele meerjarige en een tiental eenjarige kokkels per vierkante meter aanwezig. In vak 5 en 6 werden tot tientallen meerjarige en honderdtallen eenjarige kokkels per vierkante meter aangetroffen. Op 14 september 2019 zijn vak 1, 4, 5 en 6 bezocht. In vak 1 en 4 zijn nauwelijks tot geen kokkels aangetroffen. In vak 5 en 6 bleken nog steeds voldoende dichtheden van kokkels aanwezig, zodat besloten werd uit deze vakken kokkels te winnen.

De vistechniek en verplaatsing moeten geen stress op de schelpdieren geven, zodat zij zich weer kunnen ingraven en zonder beschadiging of stress kunnen voortleven. Daarnaast moet de nieuwe zandbodem geschikt zijn als habitat voor de kokkel.

Vak 2 is als eerste gesuppleerd en bleek eind oktober klaar. De primevakken waar de kokkels gepland waren, zijn halverwege de suppletie van vak 2 al gesuppleerd en het gesuppleerde zand bleek een week na aanbrengen al voldoende gezet en vertoonde het karakteristieke ribbelpatroon van een zandbodem. Ook waren eind oktober al benthische kiezelwieren aanwezig. De bodem werd circa 2-3 weken na aanbrengen geschikt geacht voor het uitzetten van kokkels. Qua planning was het nog even puzzelen om vak 5 en 6 voldoende beschikbaar te houden voor het vissen van kokkels, er bleek uiteindelijk een week tussentijd beschikbaar om de priming uit te voeren. De priming is uitgevoerd van 48 november, waarbij op 3 november al de Roggenplaat is opgegaan voor markering van ankerpunt en eerste locatie van handmatige bevissing. Voor handmatig vissen zijn de hoogst beschikbare dichtheden nodig voor een efficiēnte visserij.

Als vistechniek is gekozen voor het handmatig vissen met de kokkelbeugel of wonderklauw en het 'mechanisch' vissen met een waterlift. Van beide technieken is bekend dat de geviste kokkels te hergebruiken zijn, en weer verzaaid kunnen worden zonder verlies of beschadiging. De kokkelbeugel wordt vooral in de Waddenzee gebruikt en de waterlift bij de kweek van kokkels, tapijtschelpen en venusschelpen op proefpercelen in het Veerse meer.

In vak 5 en 6 is gevist op getij: zodra er water op de plaat kwam werd begonnen met de kokkelbeugel totdat het water op heuphoogte stond. Op dat moment werd (letterlijk) overgestapt op de waterlift die vanaf 0,8 meter waterdiepte kan werken. Bij afgaand water kan vervolgens weer handmatig gevist worden.

Het principe van de waterlift is dat met een 'gordiin' van waterstralen de schelpdieren uit de bodem gelift worden. De waterstralen staan schuin naar achter op de bodem gericht en blazen als het ware de toplaag met zand en bodemleven los. Het opgedwarrelde zand en de schelpdieren komen via venturi werking op een rvs-gazen zeefband waar het water, zand, de kleinste schelpdieren en bodemfauna doorheen gaan. Vissen, krabben en garnalen ontlopen de waterlift omdat ze mobiel zijn. Het zand en de kleinste schelp- en bodemdieren komen weer op de bodem terecht en graven zich weer in. De verplaatsing is minder dan een meter voordat de schelpdieren op de gazen band terecht komen. Via de band komen ze boven water en worden opgevangen in viskisten. De waterdruk van de waterlift is 1 bar en de vissnelheid 1-1,5 km/uur. Deze behoedzame wijze geeft geen stress en nauwelijks beschadiging ( $<1 \%$ breuk), zodat de vangst weer verzaaid kan worden.

Rond de kentering van een volgend hoogwater werd de vangst naar vak 2 gevaren en verzaaid. Ervaringen op het Veerse Meer geven aan dat bij kleinere oppervlakten ( $<1$ hectare) het verzaaien accuraat kan gebeuren met viskisten en een rubberboot. Met viskisten kan gedoseerd worden en een rubberboot is nauwkeurig te manoeuvreren om in opeenvolgende banen te verzaaien zodat een redelijk egale bedekking aan kokkels ontstaat. 


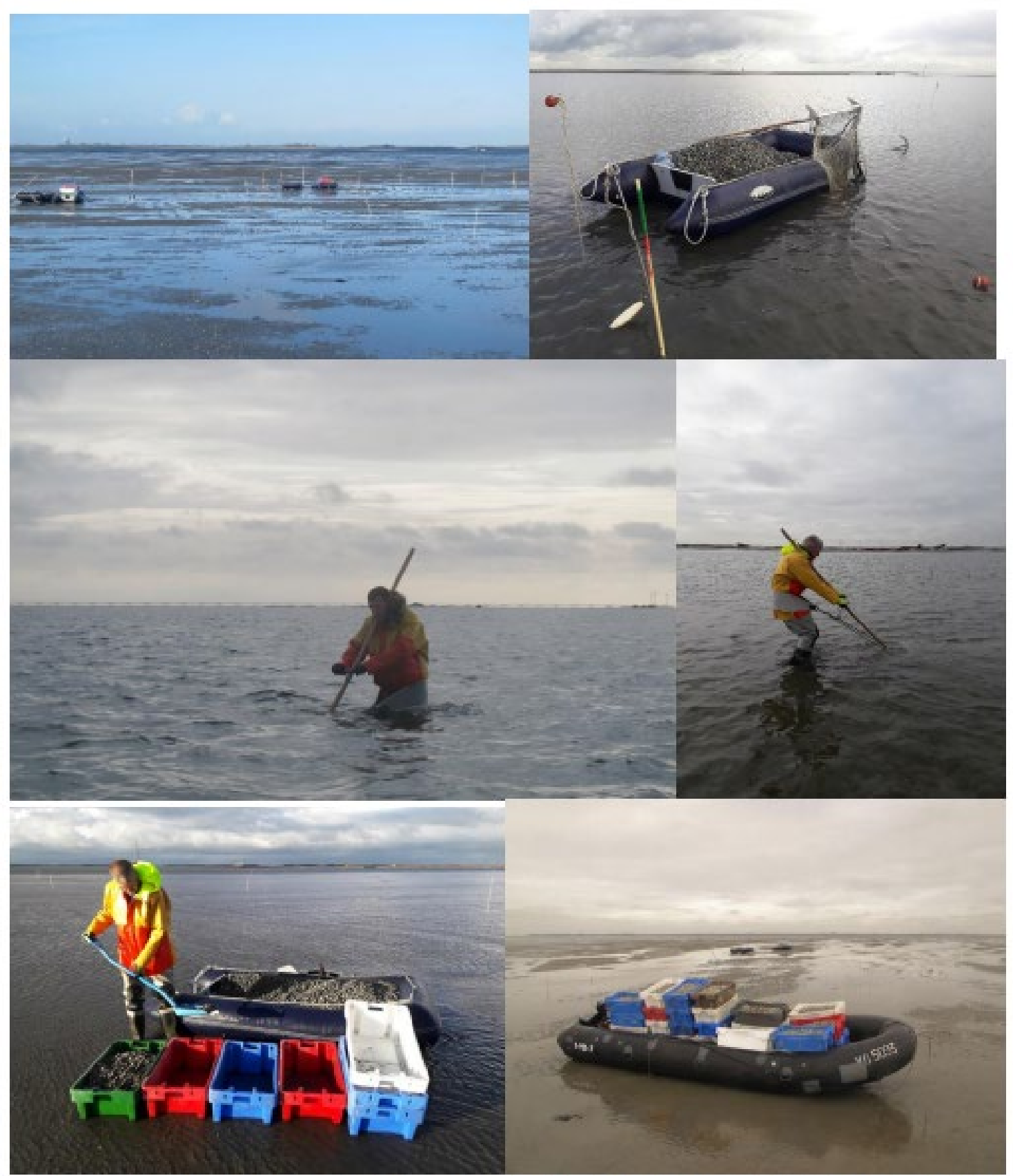

Overzicht handmatige kokkehisserij: Tijdens laagwater is met stokken aangegeven waar de hoogste dichtheden aan kokkels aarwezig zijn, die met opkomend tij bevist worden. Bij laagwater is de vangst omgeschept in viskisten om te verzaaien. 


\section{ri?}

Boskalis

MEMO
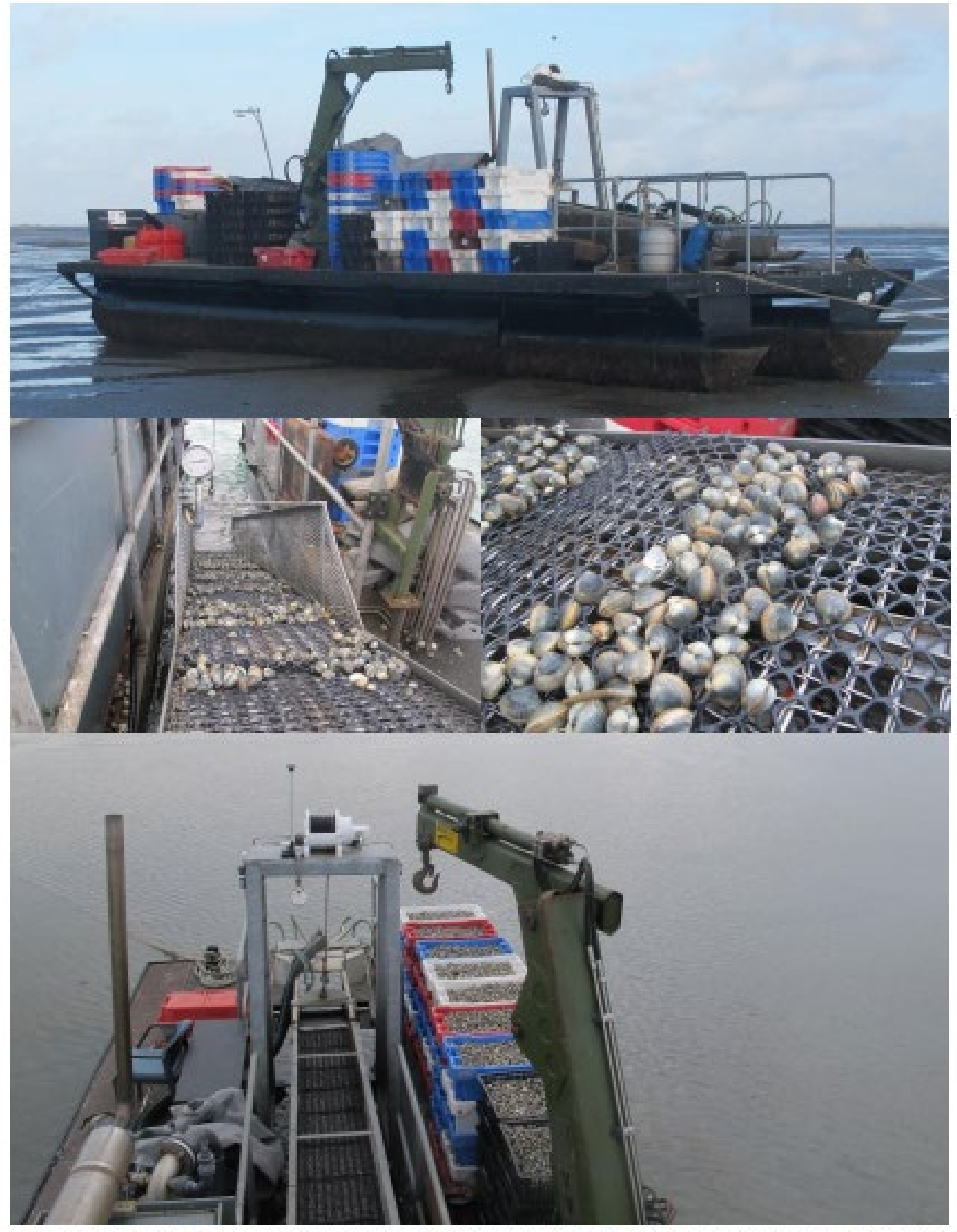

De waterift blasst water over de bodem en last schelpderen opdwarrelen de op een zeefband terecht komen. Water, zand en klein bodemleven gaan (onbeschadigd) door de zeeftand heen. Aleen de schelpdieren komen boven water en worden opgevangen. 
Van de viskisten is het gemiddelde nettogewicht bepaald aan schelpdieren, waarbij niet gecorrigeerd is voor een klein deel lege schelpen die meegekomen zijn. De vangst werd in aantallen viskisten over de primevakken verdeeld, in de bijlage staat de vangst per dag en de verdeling over de primevakken vermeld. De totaal geviste omgerekende netto hoeveelheid staat in onderstaande tabel.

\begin{tabular}{|l|c|c|}
\hline Opbrengst & $\mathrm{kg}$ & uur \\
\hline Handgevist & 3508 & 13 \\
Waterlift & 12898 & 14,5 \\
\hline Totaal & 16405 & 27,5 \\
\hline
\end{tabular}

De vangst bestond hoofdzakelijk uit kokkels met circa 3-5\% tapijtschelpen en een enkel procent lege kokkelschelpen. De kokkelbeugel en de waterlift vullen elkaar prima aan en maken het mogelijk om kokkels te vissen zolang er water op de plaat staat. Het getij werd zodoende zo lang mogelijk benut. Gemiddeld was de kokkelbeugel van 3 tot 1,5 uur voor de kentering bruikbaar en vanaf 1,5 tot 3 uur erna. De waterlift vervolgens van 2 uur voor tot 2 uur na de HW kentering, omdat deze enige diepgang vereist. De vermelde geviste tijd is de netto tijd die besteed is, dus vanaf het moment dat de handbeugel te water gaat of de waterlift wordt opgestart tot aan het moment dat de visserij stopt.

De opbrengst ligt bij de waterlift een factor 3 tot 4 hoger dan bij de kokkelbeugel in eenzelfde tijdsbestek. Dit komt omdat met de waterlift in eenzelfde tijdsbestek een groter oppervlak kan worden bevist waarbij de dichtheid aan schelpdieren voor een efficiente visserij lager mag zijn dan bij de kokkelbeugel. De combinatie van handbeugel-waterlift levert per tij het meeste op, waardoor het aantal visdagen beperkt kan blijven.

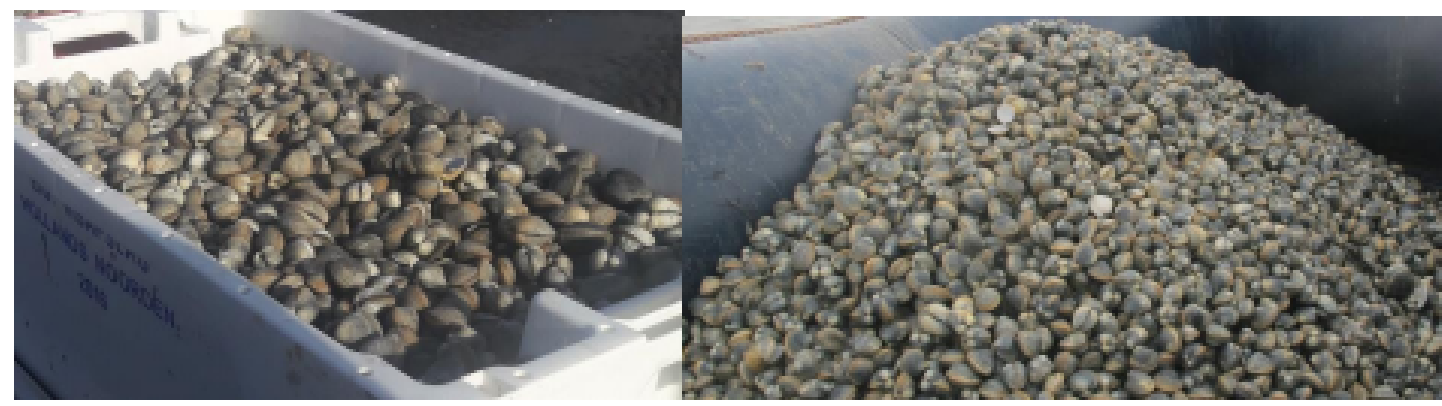

Links: geviste schelpdieren met de waterlft, rechts geviste schelpdieren met de kokkelbeugel. Met de wateriit zjin iets meer tapijtschelpen gevangen, omdat deze iets dieper in de bodem vist. De visdiepte kan overigens aangepast worden.

Het verzaaien gebeurde met een rubberboot waaruit de viskisten geleidelijk werden geleegd. Omdat de waterdiepte bij hoogwater op element 2 circa een meter was, is besloten om de rubberboot lopend voort te trekken in plaats van met de buitenboordmotor. Dit gaf een nog betere aansluiting op de eerder verzaaide banen.

Bij de volgende verzaaiing circa 24 uur later bleken de kokkels voor meer dan $95 \%$ ingegraven en op 6 november zijn geen tot nauwelijks nog levende kokkels op het zand gezien. De kokkels bleken ingegraven. Op vrijdag 8 november zijn op beide primevakken kokkels verzaaid en op beide vakken bleken de eerder verzaaide kokkels geheel ingegraven. De lege schelpen die nog op het zand lagen waren de geviste lege schelpen en was geen gevolg van uitval. Er is geen uitval waargenomen tijdens de diverse keren van verzaaien. Op primevak 1 (west) zijn omgerekend 8,2 ton kokkels verzaaid, op primevak 2 (oost) 7,8 ton. Een enkele honderd kilo kokkels zijn per abuis buiten suppletie element 2 gekomen en niet meegenomen in de verzaaide hoeveelheid.

Op vrijdag 8 november waren er reeds foeragerende scholeksters te zien op de kokkel prime vakken. 


\section{rin}

Boskalis

MEMO

ROQ-MEM-PAMENO-KOKKELLS

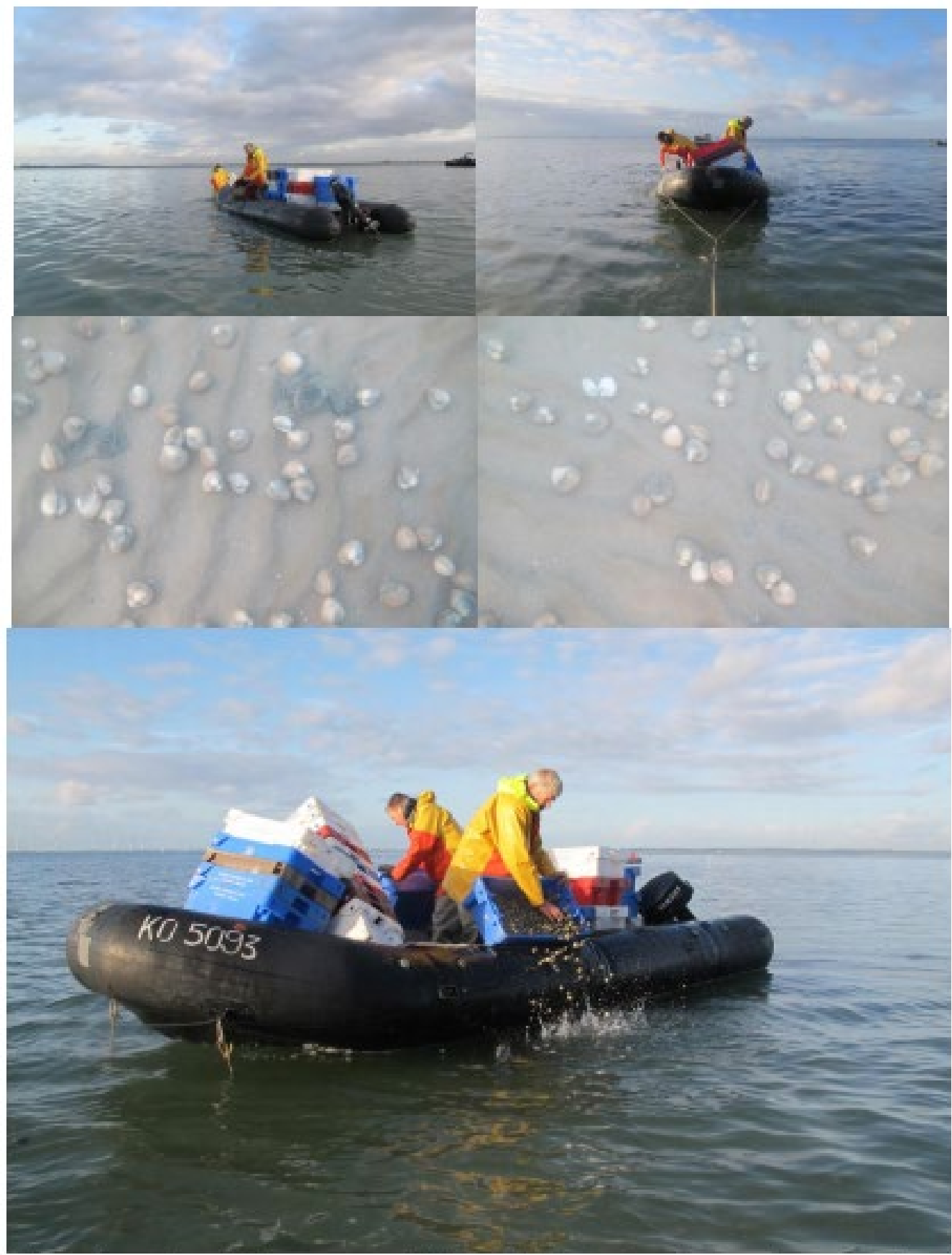

Het verzavien vanuit een rubberboot gant meest geleideligk zodat de kokkels goed over het prime vak verspreid worden. 


\section{riy \\ Boskalis}

Op 19 november zijn de primevakken nogmaals bezocht en bleken de kokkels goed ingegraven. De kokkels vertoonden een heldere kleur, als gevolg van het schone zand. De aanwezige dichtheden waren op het oog naar verwachting. Er zijn geen aanwijzingen voor enige uitval gezien.
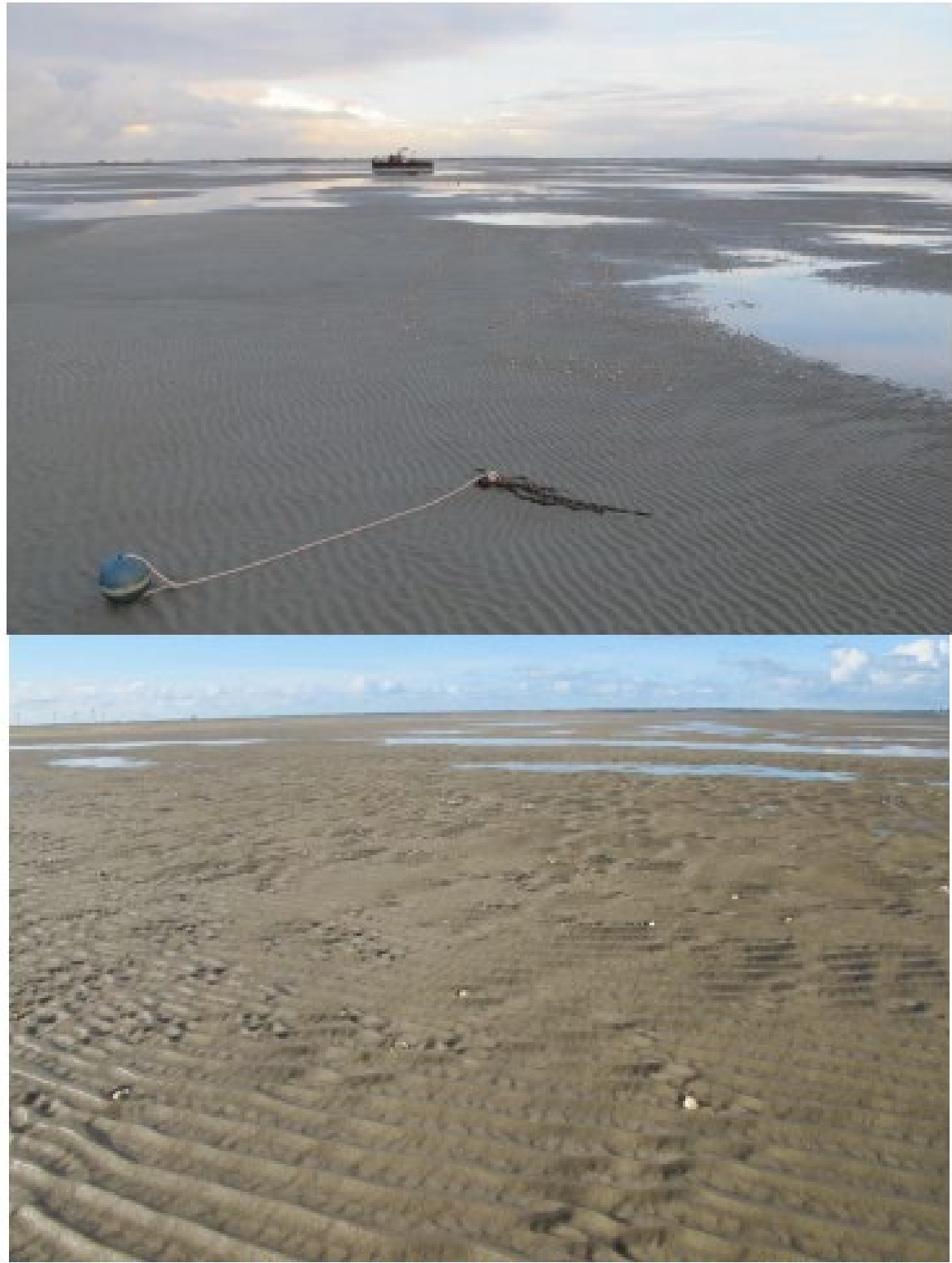

Foto boven: hoekpunt prime vak 1 met markeringsboeitje en rechts sporen van verstrooide kokkels op 6 november. Foto onder: prime vak op 19 november met nog enkeie lege scheipen aan het oppervak. 


\section{ri)}

Boskalis

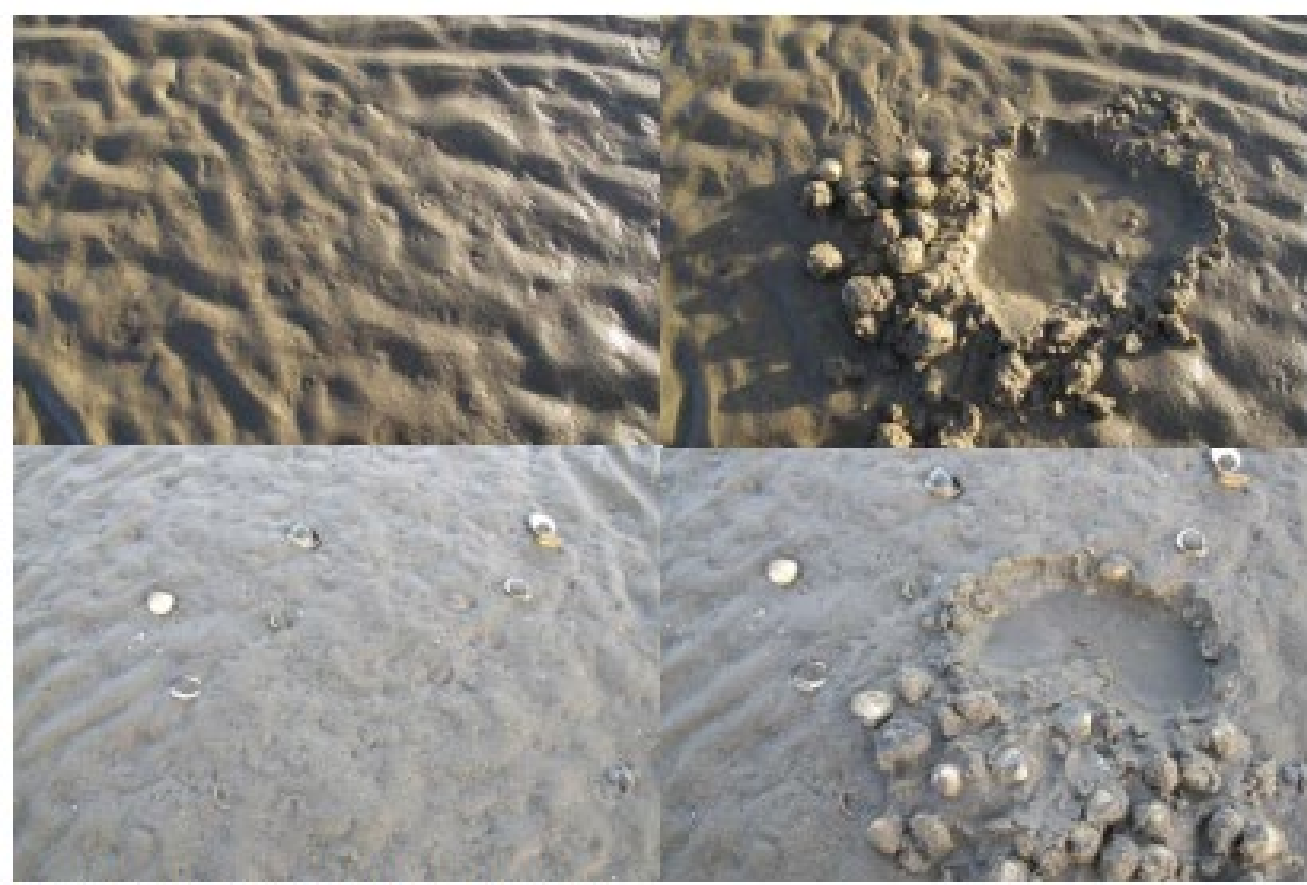

Verzaaide kakkels op 6 november, 1,5 dag na verzaaien.

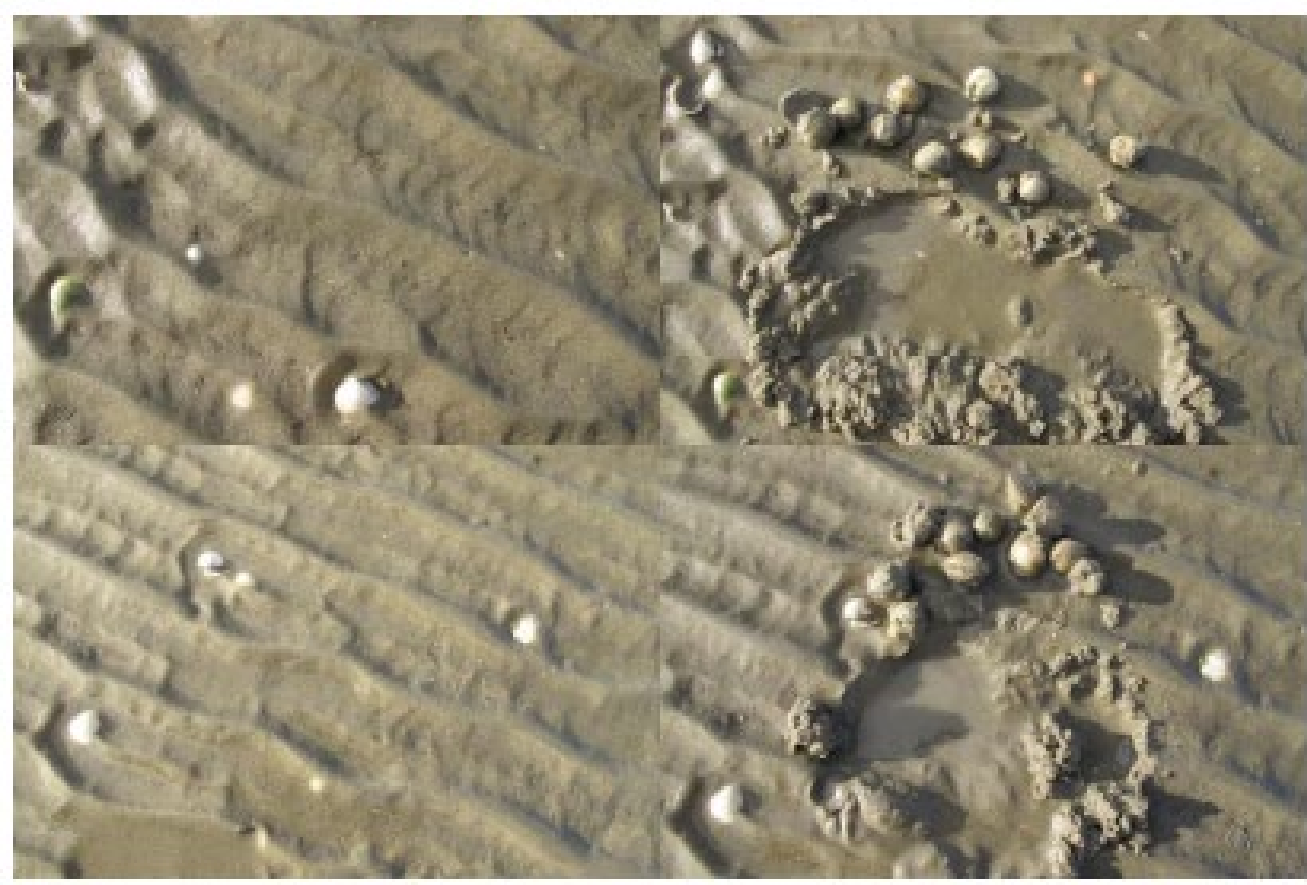

Verzaaide kakkels op 19 november, 2 weken na verzaaien. 
Een dag na de visserij zijn er nog sporen te zien van de kokkelbeugel en de waterlift. Zowel bij de kokkelbeugel als bij de waterlift is te zien dat de wadpieren geen last hebben gehad van het kokkelvissen. De aanwezigheid van wadpierhoopjes is onveranderd gebleven. Omdat dicht bij de suppletiewerkzaamheden is gevist kan gesteld worden dat de eventuele verstoring van de handmatige kokkelvisserij wegvalt tegenover de activiteiten die bij de suppletie horen. De waterlift vist rond de kentering van hoogwater, waardoor er op dat moment geen verstoring is van vogels en zeehonden. Het primen van kokkels tijdens suppletie is een goede combinatie gebleken, wel is een goede afstemming en planning van belang. De sleephopperzuiger gaat $24 / 7$ door, de aanwas van zand gaat snel en de kokkels kwamen lokaal in gewenste dichtheden voor. De suppletie kon om deze locaties heen gebeuren, anderhalve week later waren de betreffende vakken gesuppleerd.

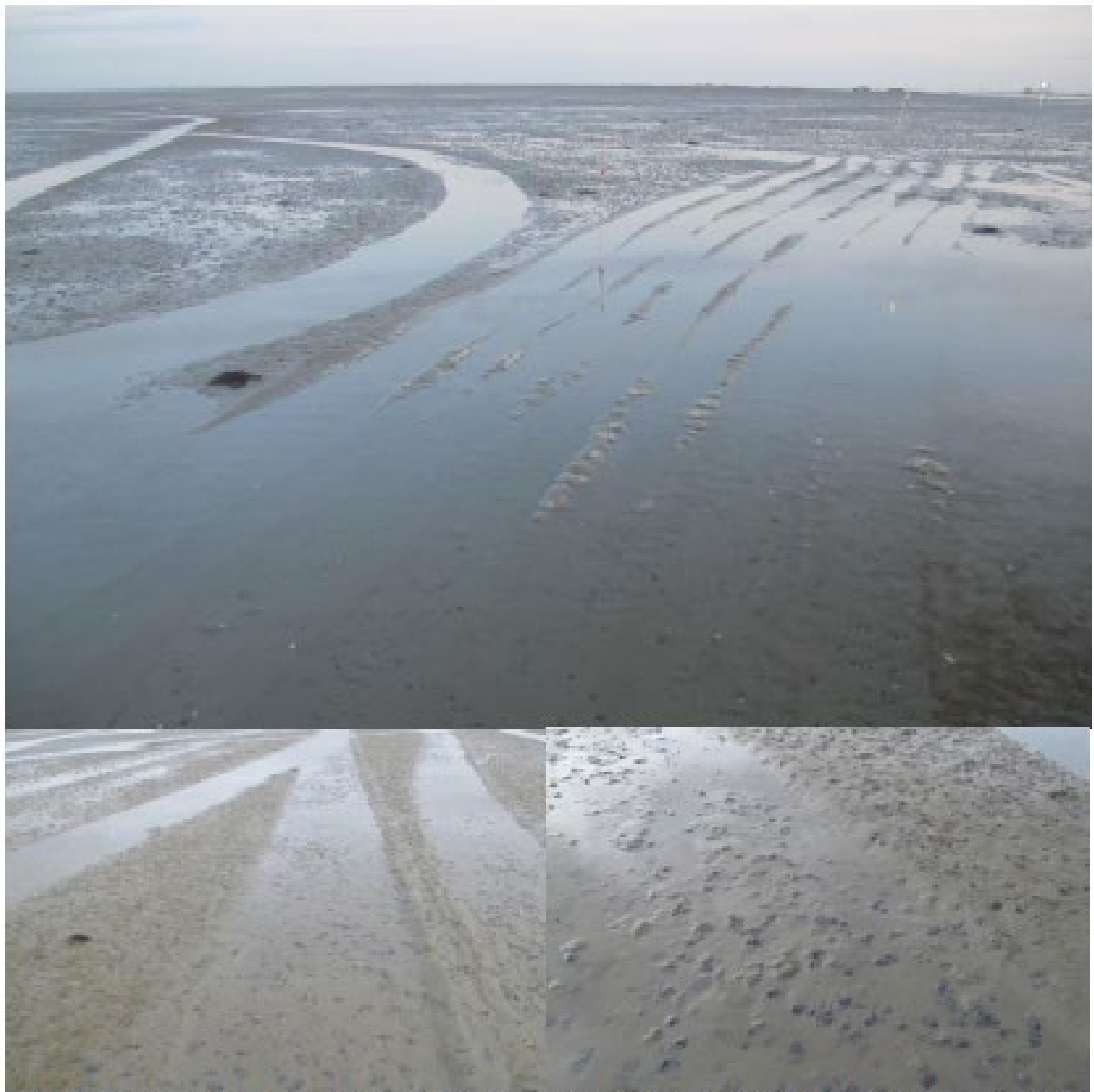

Foto boven: sporen van de kokkebeugel en de waterlift dasgs na het vissen. Foto's onder. Aleen de toplasg van bovenste centimesers wordt bevist, bodemfauna dat deper voorkomt vertocnt geen zichtbare verstoring. Er is geen beschadiging van overige bodemfauna waargenomen. 


\begin{tabular}{|c|c|c|c|c|c|c|c|c|}
\hline \multirow[b]{3}{*}{ Gewicht viskist: } & \multicolumn{8}{|c|}{ Kokkelpriming van 4 tot en met 8 november, overzicht vangst per dag en verdeling over zasivakken } \\
\hline & & & & \multicolumn{5}{|c|}{ Gemiddeld nettogewicht (levende schelpdieren, lege schelpen) } \\
\hline & & \multicolumn{2}{|c|}{$3,5 \mathrm{~kg}$} & Krat & \multicolumn{2}{|c|}{$28 \mathrm{~kg}$} & & \\
\hline Gewicht krat & & \multicolumn{2}{|c|}{$1 \mathrm{~kg}$} & Kist & \multicolumn{2}{|c|}{$35 \mathrm{~kg}$} & & \\
\hline \multicolumn{2}{|c|}{ Maandag, opkomend tij } & kist & krat & tilidsduur & $\lg$ & & & \\
\hline Handgevist & & 14 & & 2,5 & 490 & & & \\
\hline \multirow[t]{2}{*}{ Waterlift } & & 50 & 22 & 3 & 2366 & & & \\
\hline & & & & & \multicolumn{2}{|c|}{2856 totaal $\mathrm{kg}$} & \multicolumn{2}{|c|}{ verraaid aver kokke lwak 1 en 2} \\
\hline Maandag afgaand tij & & kist & krat & tilidsduur & $\mathrm{kg}$ & & & \\
\hline Handgevist & & 4 & & 1,5 & 140 & & & \\
\hline \multirow[t]{2}{*}{ Waterlift } & & 30 & & 1,5 & 1050 & & & \\
\hline & & & & & 1190 & totaal & & \\
\hline \multicolumn{2}{|l|}{ Dinsdag opkomend tij } & kist & krat & tijdsduur & $\mathrm{kg}$ & & & \\
\hline Handgevist & & 11 & & 1,5 & 385 & & & \\
\hline \multirow[t]{2}{*}{ Waterlift } & & 50 & 15 & 2,5 & 2170 & & & \\
\hline & & & & & \multicolumn{2}{|c|}{2555 totaal } & & \\
\hline Dinsdag af gaand tij & & kist & krat & tilidsduur & $\mathrm{kg}$ & & & \\
\hline Handgevist & & 4,5 & & 1,5 & 157,5 & & & \\
\hline \multirow[t]{4}{*}{ Waterlift } & & 4,5 & 11 & 1 & 465,5 & & & \\
\hline & & & & & \multicolumn{2}{|c|}{623 totas } & & \\
\hline & & & & & & & & \\
\hline & & & & & \multicolumn{4}{|c|}{$4368 \mathrm{~kg}$ verzaaid op kokkelvak 1 (west) } \\
\hline & & & & & & & & \\
\hline \multicolumn{2}{|l|}{ Woensdag afgaand tij } & kist & krat & tilidsduur & $\lg$ & & & \\
\hline Handgevist & & 26 & & 3,5 & 910 & & & \\
\hline \multirow[t]{2}{*}{ Waterlift } & & 60 & & 2 & 2100 & & & \\
\hline & & & & & 3010 & totaal & & \\
\hline Donderdag oplomen & $d t i j$ & kist & krat & tilidsduur & $\mathrm{kg}$ & & & \\
\hline Handgevist & & & & & 0 & & & \\
\hline Waterlift & & 14 & 26 & 1 & 1218 & & & \\
\hline & & & & & 1218 & totaal & & \\
\hline & & & & & & & & \\
\hline & & & & & 4228 & kg verzaai & d op kokkelvak 2 (oo & \\
\hline & & & & & & & & \\
\hline Donderdag afgasnd t & & kist & krat & tijdsduur & $\lg$ & & & \\
\hline Handgevist & & 25 & & 1,5 & 875 & & & \\
\hline Waterlift & & 65 & & 2 & 2275 & & & \\
\hline & & & & & 3150 & totasl & & \\
\hline Vrijdag opkomend tij & & kist & krat & tijdsduur & $\mathrm{kg}$ & & & \\
\hline Handgevist & & rubbe & & 1 & 550 & & & \\
\hline Waterlift & & 15 & 26 & 1,5 & 1253 & & & \\
\hline Overboord buiten sus & ppl vak 2 & kist & krat & & $\mathrm{kg}$ & & & \\
\hline & & 10 & 4 & & 462 & waservan h & lelft nog op vak 2 ver & trooid \\
\hline & & & & & & & & \\
\hline & & & & & 1572 & totaal bes: & chikbaar van vrijdag & \\
\hline & & & & & & & & \\
\hline & & & & & 4722 & kg verzaai & d kolkelvak 1 en 2 (o & st+west] \\
\hline
\end{tabular}




\section{Bijlage 3 Hoogte in $\mathrm{cm}$ NAP per droogvalduurklassen}

\begin{tabular}{|ccc|} 
Droogvalduurklassen & Hoogte $\geq$ in cm NAP & Hoogte $<$ in cm NAP \\
\hline $\mathbf{0 - 1 0}$ & -2.01 & -1.19 \\
$\mathbf{1 0 - 2 0}$ & -1.19 & -0.97 \\
$\mathbf{2 0 - 3 0}$ & -0.97 & -0.73 \\
$\mathbf{3 0 - 4 0}$ & -0.73 & -0.44 \\
$\mathbf{4 0 - 5 0}$ & -0.44 & -0.05 \\
$\mathbf{5 0 - 6 0}$ & -0.05 & 0.39 \\
$\mathbf{6 0 - 7 0}$ & 0.39 & 0.76 \\
$\mathbf{7 0 - 8 0}$ & 0.76 & 1.02 \\
$\mathbf{8 0 - 9 0}$ & 1.02 & 1.24 \\
$\mathbf{9 0 - 1 0 0}$ & 1.24 & 2.07 \\
\hline
\end{tabular}




\section{Bijlage 4 Voorkomen benthos}

Tabel 12 Voorkomen (\% van de 113 locaties in 2015, 112 locaties in 2019 en 113 locaties in 2020 waar een soort is aangetroffen) en dichtheden (aantal individuen per $\mathrm{m}^{2}$ ) per aangetroffen taxa op de Roggenplaat in 2015, 2019 en 2020. Taxa staan geordend naar hun voorkomen in 2020.

\begin{tabular}{|c|c|c|c|c|c|c|c|c|c|c|c|c|}
\hline \multirow[b]{2}{*}{ Taxa } & \multicolumn{4}{|c|}{2015} & \multicolumn{4}{|c|}{2019} & \multicolumn{4}{|c|}{2020} \\
\hline & $\%$ & $\mu$ & \pm & sd & $\%$ & $\mu$ & \pm & sd & $\%$ & $\mu$ & \pm & sd \\
\hline Scoloplos armiger & 90 & 719 & \pm & 977 & 89 & 746 & \pm & 809 & 84 & 346 & \pm & 480 \\
\hline Urothoe poseidonis & 77 & 747 & \pm & 1046 & 77 & 872 & \pm & 1133 & 72 & 808 & \pm & 1199 \\
\hline Hediste diversicolor & 28 & 20 & \pm & 46 & 62 & 152 & \pm & 191 & 67 & 147 & \pm & 222 \\
\hline Pygospio elegans & 50 & 68 & \pm & 155 & 66 & 170 & \pm & 298 & 60 & 91 & \pm & 126 \\
\hline Arenicola marina & 52 & 47 & \pm & 92 & 61 & 48 & \pm & 59 & 52 & 35 & \pm & 44 \\
\hline Aphelochaeta spp. & 58 & 860 & \pm & 2205 & 53 & 574 & \pm & 1344 & 52 & 510 & \pm & 1212 \\
\hline Capitellidae & 49 & 293 & \pm & 1568 & 44 & 100 & \pm & 300 & 51 & 439 & \pm & 1763 \\
\hline Oligochaeta & 56 & 693 & \pm & 1718 & 55 & 347 & \pm & 885 & 44 & 399 & \pm & 1611 \\
\hline Limecola balthica & 71 & 165 & \pm & 365 & 61 & 107 & \pm & 227 & 42 & 40 & \pm & 62 \\
\hline Peringia ulvae & 33 & 136 & \pm & 459 & 16 & 88 & \pm & 462 & 33 & 153 & \pm & 348 \\
\hline Nephtys cirrosa & 13 & 8 & \pm & 22 & 6 & 3 & \pm & 12 & 32 & 26 & \pm & 52 \\
\hline $\begin{array}{l}\text { Heteromastus } \\
\text { filiformis }\end{array}$ & 19 & 21 & \pm & 64 & 38 & 66 & \pm & 225 & 31 & 48 & \pm & 200 \\
\hline Cerastoderma edule & 46 & 60 & \pm & 103 & 40 & 66 & \pm & 184 & 30 & 20 & \pm & 38 \\
\hline Corophium arenarium & 39 & 218 & \pm & 654 & 38 & 112 & \pm & 388 & 30 & 63 & \pm & 222 \\
\hline Lanice conchilega & 33 & 188 & \pm & 527 & 33 & 95 & \pm & 238 & 30 & 89 & \pm & 229 \\
\hline Polydora cornuta & 12 & 15 & \pm & 63 & 27 & 55 & \pm & 241 & 28 & 82 & \pm & 237 \\
\hline Malacoceros tetracerus & 15 & 18 & \pm & 67 & 25 & 219 & \pm & 1107 & 25 & 152 & \pm & 444 \\
\hline Streblospio benedicti & & & & & 25 & 27 & \pm & 76 & 25 & 44 & \pm & 165 \\
\hline Spio martinensis & 17 & 10 & \pm & 29 & 27 & 25 & \pm & 56 & 24 & 18 & \pm & 44 \\
\hline Eteone spp. & 41 & 45 & \pm & 90 & 43 & 42 & \pm & 74 & 23 & 15 & \pm & 31 \\
\hline Bathyporeia sarsi & 21 & 39 & \pm & 130 & 16 & 16 & \pm & 61 & 22 & 24 & \pm & 70 \\
\hline Phyllodoce mucosa & 32 & 69 & \pm & 267 & 20 & 16 & \pm & 43 & 19 & 24 & \pm & 93 \\
\hline Nephtys hombergii & 34 & 16 & \pm & 24 & 19 & 8 & \pm & 18 & 18 & 9 & \pm & 23 \\
\hline Crangon crangon & 29 & 18 & \pm & 32 & 22 & 15 & \pm & 38 & 17 & 9 & \pm & 22 \\
\hline Nereidinae & 27 & 25 & \pm & 65 & 50 & 51 & \pm & 79 & 16 & 25 & \pm & 87 \\
\hline Glycera tridactyla & 19 & 9 & \pm & 19 & 14 & 6 & \pm & 16 & 14 & 6 & \pm & 15 \\
\hline Carcinus maenas & 10 & 5 & \pm & 16 & 6 & 3 & \pm & 10 & 12 & 6 & \pm & 19 \\
\hline Kurtiella bidentata & 12 & 11 & \pm & 43 & 3 & 1 & \pm & 7 & 12 & 9 & \pm & 28 \\
\hline Ensis spp. & 7 & 4 & \pm & 16 & 1 & 0 & \pm & 4 & 12 & 6 & \pm & 20 \\
\hline $\begin{array}{l}\text { Ruditapes } \\
\text { philippinarum }\end{array}$ & 23 & 21 & \pm & 50 & 20 & 11 & \pm & 24 & 9 & 8 & \pm & 32 \\
\hline Scrobicularia plana & 21 & 13 & \pm & 32 & 6 & 3 & \pm & 14 & 8 & 5 & \pm & 16 \\
\hline Nemertea & 7 & 5 & \pm & 20 & 10 & 5 & \pm & 17 & 7 & 3 & \pm & 13 \\
\hline Gammarus spp. & 27 & 88 & \pm & 342 & 8 & 16 & \pm & 73 & 7 & 18 & \pm & 131 \\
\hline Malmgrenia spp. & 12 & 9 & \pm & 29 & 8 & 5 & \pm & 17 & 7 & 5 & \pm & 18 \\
\hline Spiophanes bombyx & 19 & 23 & \pm & 81 & 6 & 3 & \pm & 14 & 5 & 2 & \pm & 10 \\
\hline
\end{tabular}




\begin{tabular}{|c|c|c|c|c|c|c|c|c|c|c|c|c|}
\hline Spionidae & 5 & 4 & \pm & 25 & 4 & 17 & \pm & 168 & 4 & 2 & \pm & 8 \\
\hline Bivalvia & 4 & 2 & \pm & 9 & 4 & 2 & \pm & 9 & 4 & 2 & \pm & 8 \\
\hline $\begin{array}{l}\text { Microdeutopus } \\
\text { anomalus }\end{array}$ & 1 & 8 & \pm & 69 & & & & & 4 & 3 & \pm & 17 \\
\hline Magelona mirabilis & 1 & 0 & \pm & 4 & 2 & 1 & \pm & 6 & 3 & 2 & \pm & 10 \\
\hline $\begin{array}{l}\text { Austrominius } \\
\text { modestus }\end{array}$ & 1 & 49 & \pm & 519 & & & & & 3 & 4 & \pm & 31 \\
\hline Abra spp & 2 & 1 & \pm & 9 & 4 & 4 & \pm & 26 & 2 & 1 & \pm & 6 \\
\hline Alitta succinea & 1 & 0 & \pm & 4 & 3 & 1 & \pm & 7 & 2 & 1 & \pm & 6 \\
\hline Eumida sanguinea & & & & & 2 & 1 & \pm & 6 & 2 & 2 & \pm & 18 \\
\hline Bathyporeia spp. & & & & & 1 & 1 & \pm & 8 & 2 & 1 & \pm & 6 \\
\hline Eunereis longissima & 3 & 2 & \pm & 12 & 1 & 0 & \pm & 4 & 2 & 1 & \pm & 6 \\
\hline Bathyporeia pilosa & 14 & 139 & \pm & 679 & & & & & 2 & 2 & \pm & 16 \\
\hline Hypereteone foliosa & 1 & 0 & \pm & 4 & 5 & 3 & \pm & 12 & 1 & 0 & \pm & 4 \\
\hline Alitta virens & 12 & 6 & \pm & 21 & 4 & 2 & \pm & 11 & 1 & 0 & \pm & 4 \\
\hline Magelona johnstoni & 1 & 0 & \pm & 4 & 1 & 1 & \pm & 8 & 1 & 0 & \pm & 4 \\
\hline Microphthalmus & 2 & 1 & \pm & 6 & 1 & 0 & \pm & 4 & 1 & 2 & \pm & 20 \\
\hline Ophiura & & & & & 1 & 0 & \pm & 4 & 1 & 0 & \pm & 4 \\
\hline Magelona & 4 & 2 & \pm & 8 & & & & & 1 & 0 & \pm & 4 \\
\hline $\begin{array}{l}\text { Microprotopus } \\
\text { maculatus }\end{array}$ & 2 & 1 & \pm & 6 & & & & & 1 & 0 & \pm & 4 \\
\hline Notomastus latericeus & 2 & 1 & \pm & 6 & & & & & 1 & 0 & \pm & 4 \\
\hline Lepidochitona spp. & & & & & 2 & 1 & \pm & 9 & 0 & 0 & \pm & 0 \\
\hline Nephtys spp. & 3 & 1 & \pm & 7 & 2 & 1 & \pm & 9 & 0 & 0 & \pm & 0 \\
\hline Myrianida & 2 & 1 & \pm & 9 & 2 & 1 & \pm & 6 & 0 & 0 & \pm & 0 \\
\hline Venerida & & & & & 2 & 1 & \pm & 6 & 0 & 0 & \pm & 0 \\
\hline Achelia echinata & & & & & 1 & 0 & \pm & 4 & 0 & 0 & \pm & 0 \\
\hline Diastylis bradyi & & & & & 1 & 0 & \pm & 4 & 0 & 0 & \pm & 0 \\
\hline Enteropneusta & & & & & 1 & 0 & \pm & 4 & 0 & 0 & \pm & 0 \\
\hline Isopoda & & & & & 1 & 0 & \pm & 4 & 0 & 0 & \pm & 0 \\
\hline Mediomastus fragilis & 3 & 1 & \pm & 7 & 1 & 0 & \pm & 4 & 0 & 0 & \pm & 0 \\
\hline Melinna elisabethae & & & & & 1 & 0 & \pm & 4 & 0 & 0 & \pm & 0 \\
\hline Mya spp. & 3 & 1 & \pm & 7 & 1 & 0 & \pm & 4 & 0 & 0 & \pm & 0 \\
\hline Oxydromus flexuosus & & & & & 1 & 0 & \pm & 4 & 0 & 0 & \pm & 0 \\
\hline Platyhelminthes & & & & & 1 & 0 & \pm & 4 & 0 & 0 & \pm & 0 \\
\hline Venerupis corrugata & 1 & 0 & \pm & 4 & 1 & 0 & \pm & 4 & 0 & 0 & \pm & 0 \\
\hline Streblospio shrubsolii & 19 & 41 & \pm & 164 & & & & & 0 & 0 & \pm & 0 \\
\hline Eumida & 12 & 48 & \pm & 218 & & & & & 0 & 0 & \pm & 0 \\
\hline $\begin{array}{l}\text { Pseudopolydora } \\
\text { pulchra }\end{array}$ & 6 & 14 & \pm & 73 & & & & & 0 & 0 & \pm & 0 \\
\hline Mytilus edulis & 2 & 3 & \pm & 27 & & & & & 0 & 0 & \pm & 0 \\
\hline Magallana gigas & 2 & 2 & \pm & 14 & & & & & 0 & 0 & \pm & 0 \\
\hline Microdeutopus spp. & 1 & 15 & \pm & 164 & & & & & 0 & 0 & \pm & 0 \\
\hline Ophelia rathkei & 1 & 14 & \pm & 148 & & & & & 0 & 0 & \pm & 0 \\
\hline Corophium volutator & 1 & 1 & \pm & 12 & & & & & 0 & 0 & \pm & 0 \\
\hline $\begin{array}{l}\text { Monocorophium } \\
\text { acherusicum }\end{array}$ & 1 & 1 & \pm & 12 & & & & & 0 & 0 & \pm & 0 \\
\hline Hesionidae & 1 & 1 & \pm & 8 & & & & & 0 & 0 & \pm & 0 \\
\hline $\begin{array}{l}\text { Crassicorophium } \\
\text { bonellii }\end{array}$ & 1 & 0 & \pm & 4 & & & & & 0 & 0 & \pm & 0 \\
\hline Crepidula fornicata & 1 & 0 & \pm & 4 & & & & & 0 & 0 & \pm & 0 \\
\hline GASTROPODA & 1 & 0 & \pm & 4 & & & & & 0 & 0 & \pm & 0 \\
\hline Littorina littorea & 1 & 0 & \pm & 4 & & & & & 0 & 0 & \pm & 0 \\
\hline Nephtys caeca & 1 & 0 & \pm & 4 & & & & & 0 & 0 & \pm & 0 \\
\hline
\end{tabular}


0 


\section{Bijlage 5 Voorkomen benthos Suppleties}

\begin{tabular}{|c|c|c|c|c|c|c|c|c|c|c|c|c|c|c|c|c|c|c|c|c|c|c|c|c|}
\hline \multirow[b]{2}{*}{ Soort } & \multicolumn{3}{|c|}{$\begin{array}{c}\text { Suppletie } 1 \\
n=9\end{array}$} & \multicolumn{3}{|c|}{$\begin{array}{c}\text { Suppletie } 2 \\
\mathrm{n}=12\end{array}$} & \multicolumn{3}{|c|}{$\begin{array}{c}\text { Suppletie } 3 \\
n=9\end{array}$} & \multicolumn{3}{|c|}{$\begin{array}{c}\text { Suppletie } 4 \\
n=9\end{array}$} & \multicolumn{3}{|c|}{$\begin{array}{c}\begin{array}{c}\text { Suppletie } 5 \\
n=9\end{array} \\
\end{array}$} & \multicolumn{3}{|c|}{$\begin{array}{c}\text { Suppletie } 6 \\
n=20\end{array}$} & \multicolumn{3}{|c|}{$\begin{array}{c}\text { Suppletie } 7 \\
n=20\end{array}$} & \multicolumn{3}{|c|}{$\begin{array}{c}\text { Roggenplaat } \\
n=97\end{array}$} \\
\hline & $\%$ & $\mu$ & sd & $\%$ & $\mu$ & sd & $\%$ & $\mu$ & sd & $\%$ & $\mu$ & Sd & $\%$ & $\mu$ & sd & $\%$ & $\mu$ & sd & $\%$ & $\mu$ & sd & $\%$ & $\mu$ & sd \\
\hline $\begin{array}{l}\text { Aphelochaeta } \\
\text { spp. }\end{array}$ & 22 & 14 & \pm 30 & 17 & 32 & \pm 87 & 44 & 80 & \pm 123 & 0 & & & 0 & & & 55 & 57 & 96 & 5 & 2 & 10 & 57 & 589 & \pm 1291 \\
\hline $\begin{array}{l}\text { Arenicola } \\
\text { marina }\end{array}$ & 89 & 80 & \pm 62 & 100 & 124 & \pm 56 & 44 & 28 & \pm 42 & 11 & 5 & \pm 14 & 56 & 109 & \pm 141 & 50 & 28 & \pm 32 & 5 & 2 & \pm 10 & 53 & 34 & \pm 44 \\
\hline $\begin{array}{l}\text { Bathyporeia } \\
\text { pilosa }\end{array}$ & 22 & 311 & \pm 842 & 0 & & & 0 & & & 33 & 160 & \pm 321 & 33 & 38 & \pm 83 & 0 & & & 10 & 6 & \pm 21 & 2 & 2 & \pm 18 \\
\hline $\begin{array}{l}\text { Bathyporeia } \\
\text { sarsi }\end{array}$ & 78 & 160 & \pm 123 & 75 & 173 & \pm 390 & 67 & 113 & \pm 204 & 67 & 104 & \pm 146 & 78 & 217 & \pm 235 & 90 & 106 & \pm 89 & 70 & 85 & \pm 92 & 13 & 11 & \pm 39 \\
\hline Capitellidae & 11 & 5 & \pm 14 & 42 & 35 & \pm 57 & 11 & 14 & \pm 42 & 0 & & & 11 & 5 & \pm 14 & 35 & 49 & \pm 141 & 5 & 2 & \pm 10 & 57 & 509 & \pm 1896 \\
\hline $\begin{array}{l}\text { Cerastoderma } \\
\text { edule }\end{array}$ & 11 & 5 & \pm 14 & 0 & & & 0 & & & 0 & & & 0 & & & 30 & 15 & \pm 25 & 5 & 2 & \pm 10 & 34 & 22 & \pm 41 \\
\hline $\begin{array}{l}\text { Corophium } \\
\text { arenarium }\end{array}$ & 22 & 9 & \pm 19 & 50 & 28 & \pm 33 & 44 & 24 & \pm 31 & 44 & 47 & \pm 83 & 11 & 5 & \pm 14 & 40 & 28 & \pm 42 & 30 & 17 & \pm 29 & 31 & 70 & \pm 239 \\
\hline Eteone spp. & 11 & 14 & \pm 42 & 42 & 25 & \pm 34 & 33 & 14 & \pm 21 & 11 & 5 & \pm 14 & 0 & & & 25 & 21 & \pm 42 & 15 & 6 & \pm 16 & 25 & 15 & \pm 31 \\
\hline $\begin{array}{l}\text { Hediste } \\
\text { diversicolor }\end{array}$ & 78 & 42 & \pm 37 & 75 & 138 & \pm 128 & 67 & 57 & \pm 60 & 22 & 24 & \pm 57 & 33 & 24 & \pm 37 & 60 & 72 & \pm 128 & 15 & 6 & \pm 16 & 70 & 166 & \pm 234 \\
\hline $\begin{array}{l}\text { Heteromastus } \\
\text { filiformis }\end{array}$ & 22 & 9 & \pm 19 & 17 & 7 & \pm 17 & 22 & 9 & \pm 19 & 11 & 5 & \pm 14 & 0 & & & 30 & 15 & \pm 25 & 0 & & & 32 & 54 & \pm 216 \\
\hline $\begin{array}{l}\text { Limecola } \\
\text { balthica }\end{array}$ & 11 & 5 & \pm 14 & 67 & 42 & \pm 41 & 44 & 28 & \pm 37 & 11 & 5 & \pm 14 & 44 & 38 & \pm 69 & 45 & 23 & \pm 32 & 15 & 6 & \pm 16 & 43 & 44 & \pm 66 \\
\hline Nemertea & 22 & 9 & \pm 19 & 17 & 7 & \pm 17 & 33 & 28 & \pm 56 & 0 & & & 22 & 42 & \pm 90 & 25 & 13 & \pm 24 & 5 & 2 & \pm 10 & 8 & 4 & \pm 14 \\
\hline
\end{tabular}




\begin{tabular}{|c|c|c|c|c|c|c|c|c|c|c|c|c|c|c|c|c|c|c|c|c|c|c|c|c|}
\hline \multirow[b]{2}{*}{$\begin{array}{l}\text { Nephtys } \\
\text { cirrosa }\end{array}$} & \multicolumn{3}{|c|}{$\begin{array}{c}\text { Suppletie } 1 \\
n=9\end{array}$} & \multicolumn{3}{|c|}{$\begin{array}{c}\text { Suppletie } 2 \\
n=12\end{array}$} & \multicolumn{3}{|c|}{$\begin{array}{c}\text { Suppletie } 3 \\
n=9\end{array}$} & \multicolumn{3}{|c|}{$\begin{array}{c}\text { Suppletie } 4 \\
n=9\end{array}$} & \multicolumn{3}{|c|}{$\begin{array}{c}\text { Suppletie } 5 \\
n=9\end{array}$} & \multicolumn{3}{|c|}{$\begin{array}{c}\text { Suppletie } 6 \\
n=20\end{array}$} & \multicolumn{3}{|c|}{$\begin{array}{c}\text { Suppletie } 7 \\
n=20\end{array}$} & \multicolumn{3}{|c|}{$\begin{array}{c}\text { Roggenplaat } \\
n=97\end{array}$} \\
\hline & 78 & 99 & \pm 93 & 50 & 35 & \pm 44 & 33 & 33 & \pm 59 & 33 & 14 & \pm 21 & 56 & 24 & \pm 22 & 65 & 83 & \pm 100 & 90 & 127 & \pm 146 & 26 & 21 & \pm 49 \\
\hline Oligochaeta & 11 & 5 & \pm 14 & 17 & 14 & \pm 38 & 44 & 28 & \pm 42 & 22 & 9 & \pm 19 & 22 & 9 & \pm 19 & 40 & 461 & \pm 1466 & 0 & & & 49 & 463 & \pm 1731 \\
\hline Ophelia & 0 & 0 & & 0 & 0 & 0 & 0 & 0 & 0 & 11 & 5 & \pm 14 & 0 & & & 10 & 172 & \pm 720 & 0 & & & 0 & & \\
\hline Peringia ulvae & 11 & 14 & \pm 42 & 17 & 103 & \pm 240 & 0 & 0 & 0 & 0 & & & 11 & 5 & \pm 14 & 25 & 36 & \pm 73 & 10 & 4 & \pm 13 & 34 & 162 & \pm 366 \\
\hline $\begin{array}{l}\text { Phyllodoce } \\
\text { mucosa }\end{array}$ & 0 & 0 & \pm 0 & 33 & 14 & \pm 21 & 11 & 5 & \pm 14 & 0 & & & 0 & & & 15 & 6 & \pm 16 & 0 & & & 20 & 27 & \pm 100 \\
\hline $\begin{array}{l}\text { Pygospio } \\
\text { elegans }\end{array}$ & 78 & 330 & \pm 538 & 42 & 35 & \pm 57 & 56 & 302 & \pm 359 & 78 & 410 & \pm 523 & 100 & 146 & \pm 77 & 50 & 100 & \pm 194 & 60 & 189 & \pm 394 & 59 & 88 & \pm 128 \\
\hline $\begin{array}{l}\text { Scolelepis } \\
\text { squamata }\end{array}$ & 11 & 5 & \pm 14 & 0 & & & 0 & & & 44 & 24 & \pm 31 & 33 & 28 & \pm 48 & 10 & 4 & \pm 13 & 20 & 15 & \pm 40 & 0 & & \\
\hline $\begin{array}{l}\text { Scoloplos } \\
\text { armiger }\end{array}$ & 89 & 160 & \pm 130 & 100 & 874 & \pm 600 & 89 & 448 & \pm 288 & 33 & 80 & \pm 161 & 67 & 113 & \pm 261 & 90 & 399 & \pm 430 & 40 & 23 & \pm 40 & 85 & 361 & \pm 491 \\
\hline $\begin{array}{l}\text { Urothoe } \\
\text { poseidonis }\end{array}$ & 67 & 264 & \pm 590 & 83 & 608 & \pm 886 & 78 & 406 & \pm 691 & 22 & 9 & \pm 19 & 33 & 217 & \pm 515 & 70 & 248 & \pm 444 & 0 & & & 73 & 900 & \pm 1258 \\
\hline
\end{tabular}




\section{Bijlage 6 Benthos veldscreening}

Tabel 13 geeft een overzicht van soorten die per jaar in de kwalitatieve survey zijn opgenomen. Hier moet met vergelijken van soortenrijkdom tussen jaren rekening mee worden gehouden. De laatste kolom geeft weer welke soorten zijn meegenomen in de berekening voor de soortenrijkdom voor de kwalitatieve benthos data. Deze soorten zijn gekozen op basis van een vergelijking tussen 2017 en 2020, aangezien het bemonsteringspatroon van deze jaren het meest op elkaar lijken. In totaal zijn dit 23 soorten.

Tabel 13. Gescoorde parameters in het veld tijdens de kwalitatieve benthos bemonstering voor (2016 en 2017) en na (2020) aanleg van de suppleties.

\begin{tabular}{l|c|c|c|c|} 
& $\mathbf{2 0 1 6}$ & $\mathbf{2 0 1 7}$ & $\mathbf{2 0 2 0}$ & Soorten rijkdom \\
\hline Nat & $\mathrm{X}$ & $\mathrm{X}$ & $\mathrm{X}$ & \\
\hline Slib & $\mathrm{X}$ & & $\mathrm{X}$ & \\
\hline Plofzand & $\mathrm{X}$ & $\mathrm{X}$ & $\mathrm{X}$ & \\
\hline Golfribbel & $\mathrm{X}$ & $\mathrm{X}$ & $\mathrm{X}$ & \\
\hline Stroomribbel & & $\mathrm{X}$ & $\mathrm{X}$ & \\
\hline Oxidatie laag & & $\mathrm{X}$ & $\mathrm{X}$ & \\
\hline Lutumpercentage & & & $\mathrm{X}$ & \\
\hline Diatomeeën & $\mathrm{X}$ & $\mathrm{X}$ & $\mathrm{X}$ & \\
\hline Kokkelbroed & $\mathrm{X}$ & $\mathrm{X}$ & $\mathrm{X}$ & \\
\hline Wadpierhoopjes & & $\mathrm{X}$ & $\mathrm{X}$ & \\
\hline Wier & & $\mathrm{X}$ & $\mathrm{X}$ & \\
\hline Wadpier & $\mathrm{X}$ & $\mathrm{X}$ & $\mathrm{X}$ & $\mathrm{X}$ \\
\hline Nereis & $\mathrm{X}$ & $\mathrm{X}$ & $\mathrm{X}$ & $\mathrm{X}$ \\
\hline Nepthys & $\mathrm{X}$ & $\mathrm{X}$ & $\mathrm{X}$ & $\mathrm{X}$ \\
\hline Heteromastus & $\mathrm{X}$ & $\mathrm{X}$ & $\mathrm{X}$ & $\mathrm{X}$ \\
\hline Wapenworm & $\mathrm{X}$ & $\mathrm{X}$ & $\mathrm{X}$ & $\mathrm{X}$ \\
\hline Dieseltreinworm & $\mathrm{X}$ & $\mathrm{X}$ & $\mathrm{X}$ & $\mathrm{X}$ \\
\hline Lanice & $\mathrm{X}$ & $\mathrm{X}$ & $\mathrm{X}$ & $\mathrm{X}$ \\
\hline Pygospio & $\mathrm{X}$ & $\mathrm{X}$ & $\mathrm{X}$ & $\mathrm{X}$ \\
\hline Nonnetje & $\mathrm{X}$ & $\mathrm{X}$ & $\mathrm{X}$ & $\mathrm{X}$ \\
\hline Tapijtschelp & $\mathrm{X}$ & $\mathrm{X}$ & $\mathrm{X}$ & $\mathrm{X}$ \\
\hline Wadslak & $\mathrm{X}$ & $\mathrm{X}$ & $\mathrm{X}$ & $\mathrm{X}$ \\
\hline Kokkels & $\mathrm{X}$ & $\mathrm{X}$ & $\mathrm{X}$ & $\mathrm{X}$ \\
\hline Ensis & $\mathrm{X}$ & $\mathrm{X}$ & $\mathrm{X}$ & $\mathrm{X}$ \\
\hline Mya & $\mathrm{X}$ & $\mathrm{X}$ & $\mathrm{X}$ & $\mathrm{X}$ \\
\hline Alikruikje & $\mathrm{X}$ & $\mathrm{X}$ & $\mathrm{X}$ & $\mathrm{X}$ \\
\hline Platte slijkgaper & $\mathrm{X}$ & $\mathrm{X}$ & $\mathrm{X}$ & $\mathrm{X}$ \\
\hline Corophium & $\mathrm{X}$ & $\mathrm{X}$ & $\mathrm{X}$ & $\mathrm{X}$ \\
\hline Oester & $\mathrm{X}$ & $\mathrm{X}$ & $\mathrm{X}$ & $\mathrm{X}$ \\
\hline Glycera & $\mathrm{X}$ & $\mathrm{X}$ & $\mathrm{X}$ & $\mathrm{X}$ \\
\hline Bloedworm & $\mathrm{X}$ & $\mathrm{X}$ & & $\mathrm{X}$ \\
\hline Bulldozerkreeftje & $\mathrm{X}$ & $\mathrm{X}$ & $\mathrm{X}$ & $\mathrm{X}$ \\
\hline Garnaal & $\mathrm{X}$ & $\mathrm{X}$ & $\mathrm{X}$ & $\mathrm{X}$ \\
\hline Krab & $\mathrm{X}$ & $\mathrm{X}$ & $\mathrm{X}$ & $\mathrm{X}$ \\
\hline Gemshoornworm & & $\mathrm{X}$ & $\mathrm{X}$ & \\
\hline Overige vlokreeft & & $\mathrm{X}$ & $\mathrm{X}$ & \\
\hline Mossel & & & $\mathrm{X}$ & \\
\hline Notomastus & & & $\mathrm{X}$ & \\
\hline
\end{tabular}




\section{Bijlage 7 Resultaten Benthos Monitoring veldscreening}
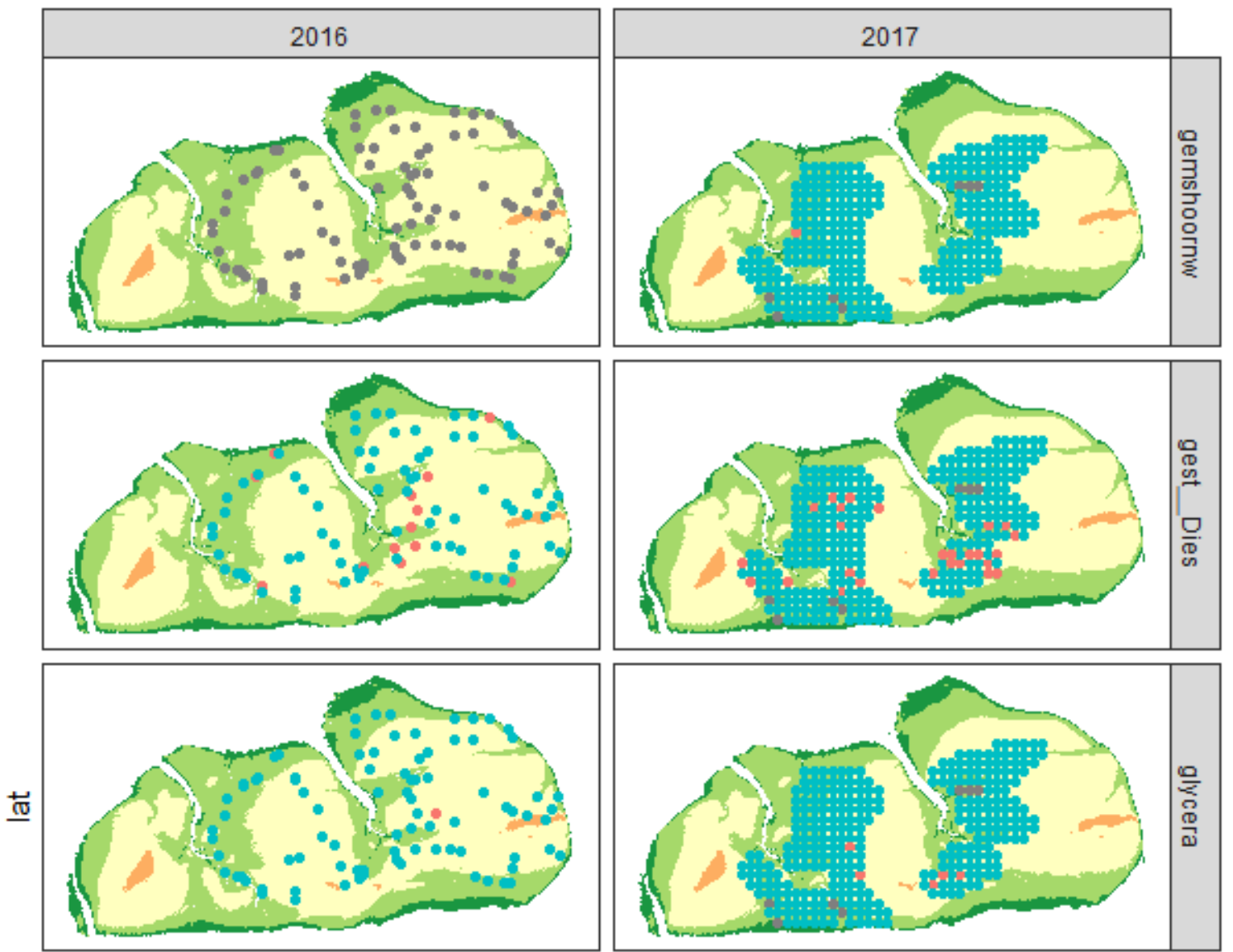

hoogte [m NAP]

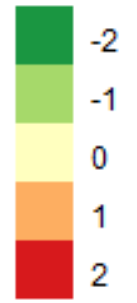

Aanwezig
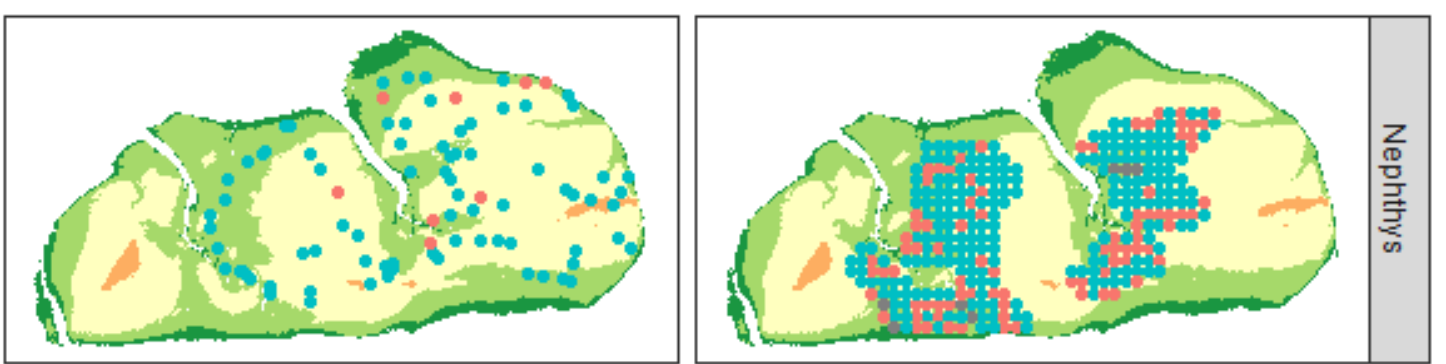

- ja
- nee
- NA
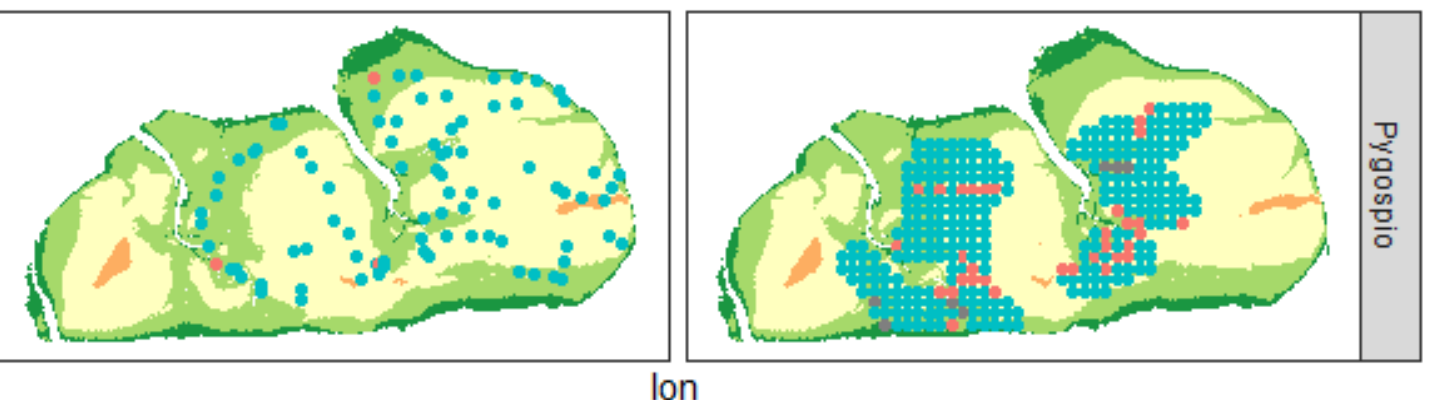

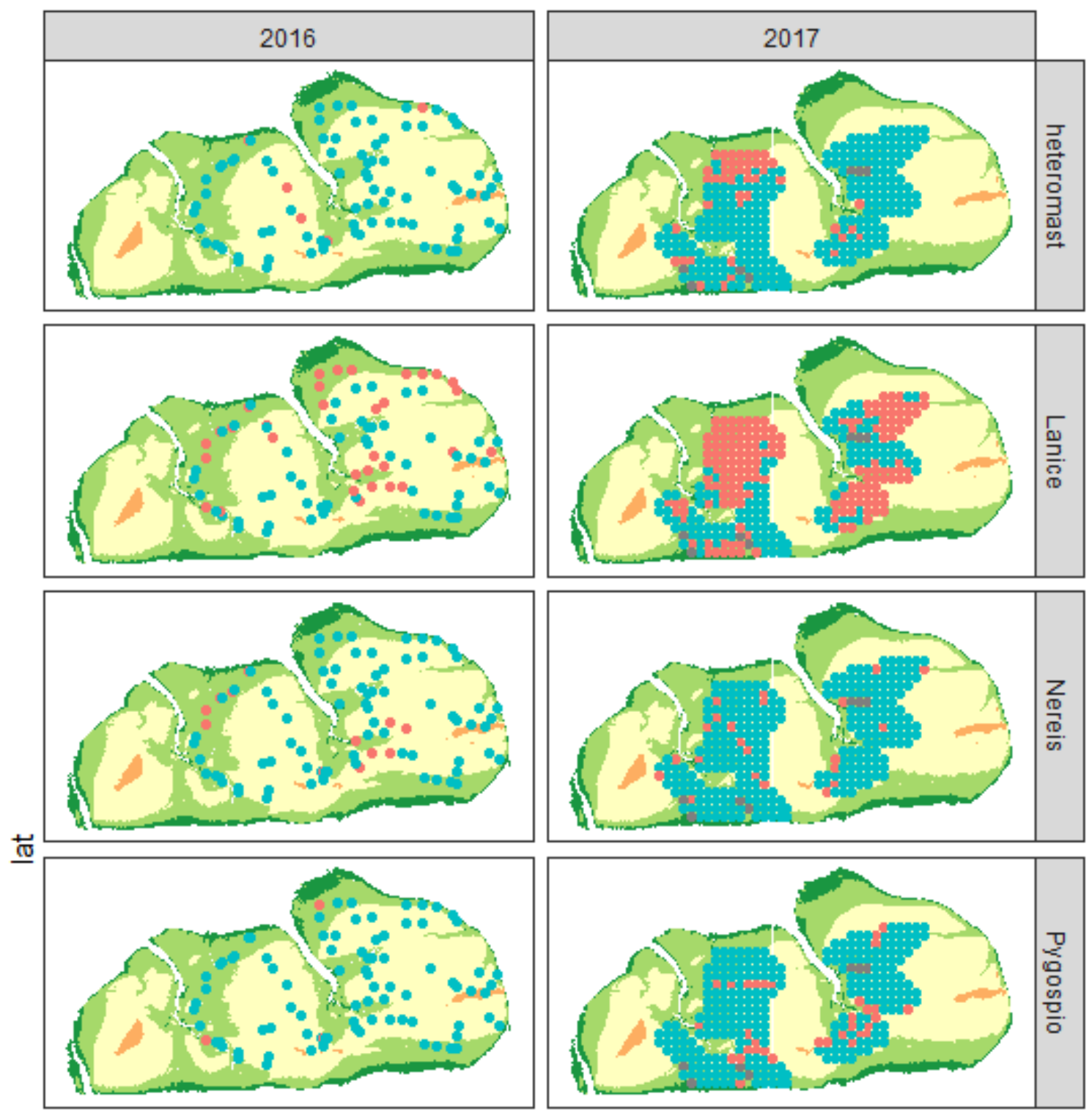

hoogte [m NAP]
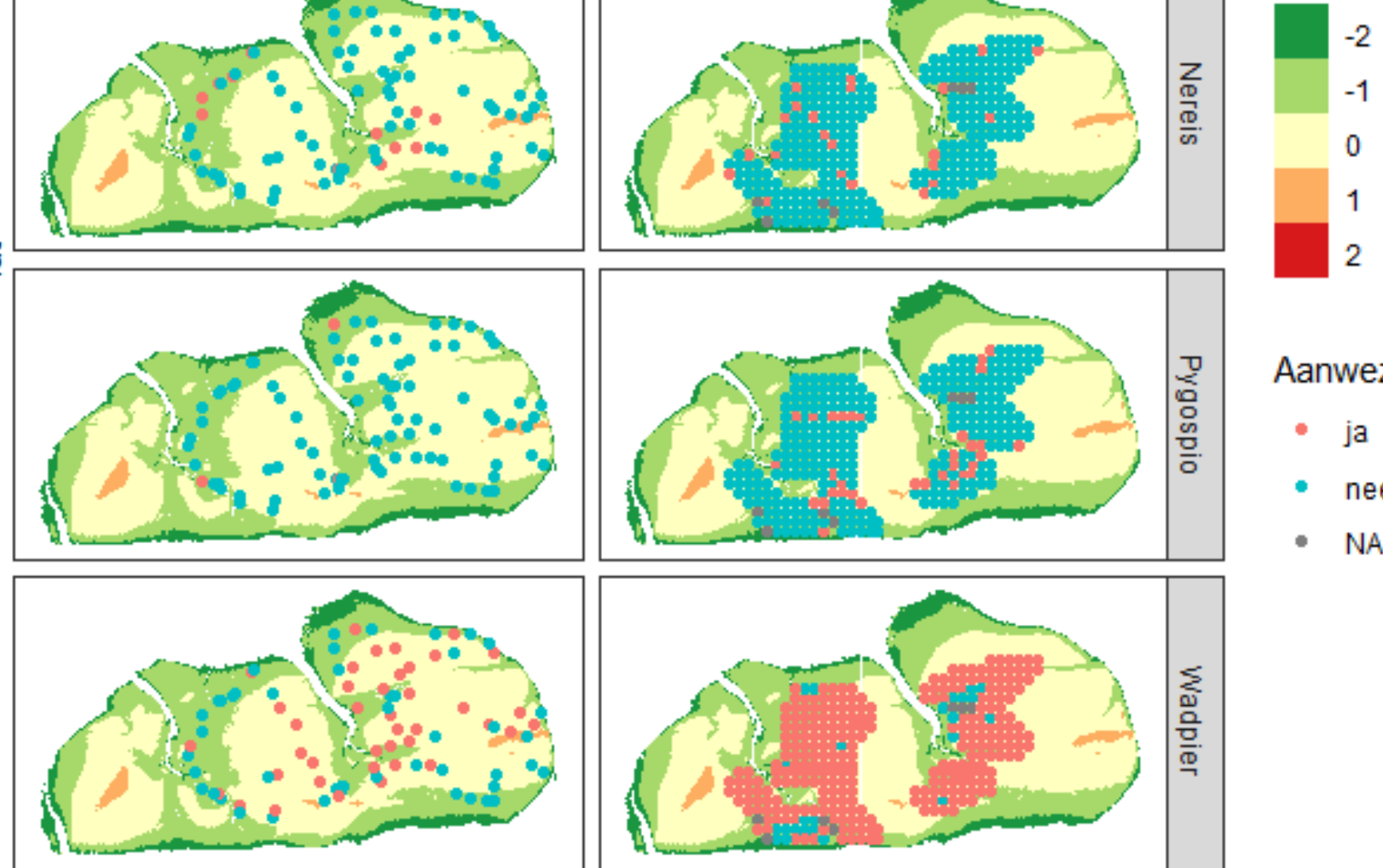

\section{Aanwezig}
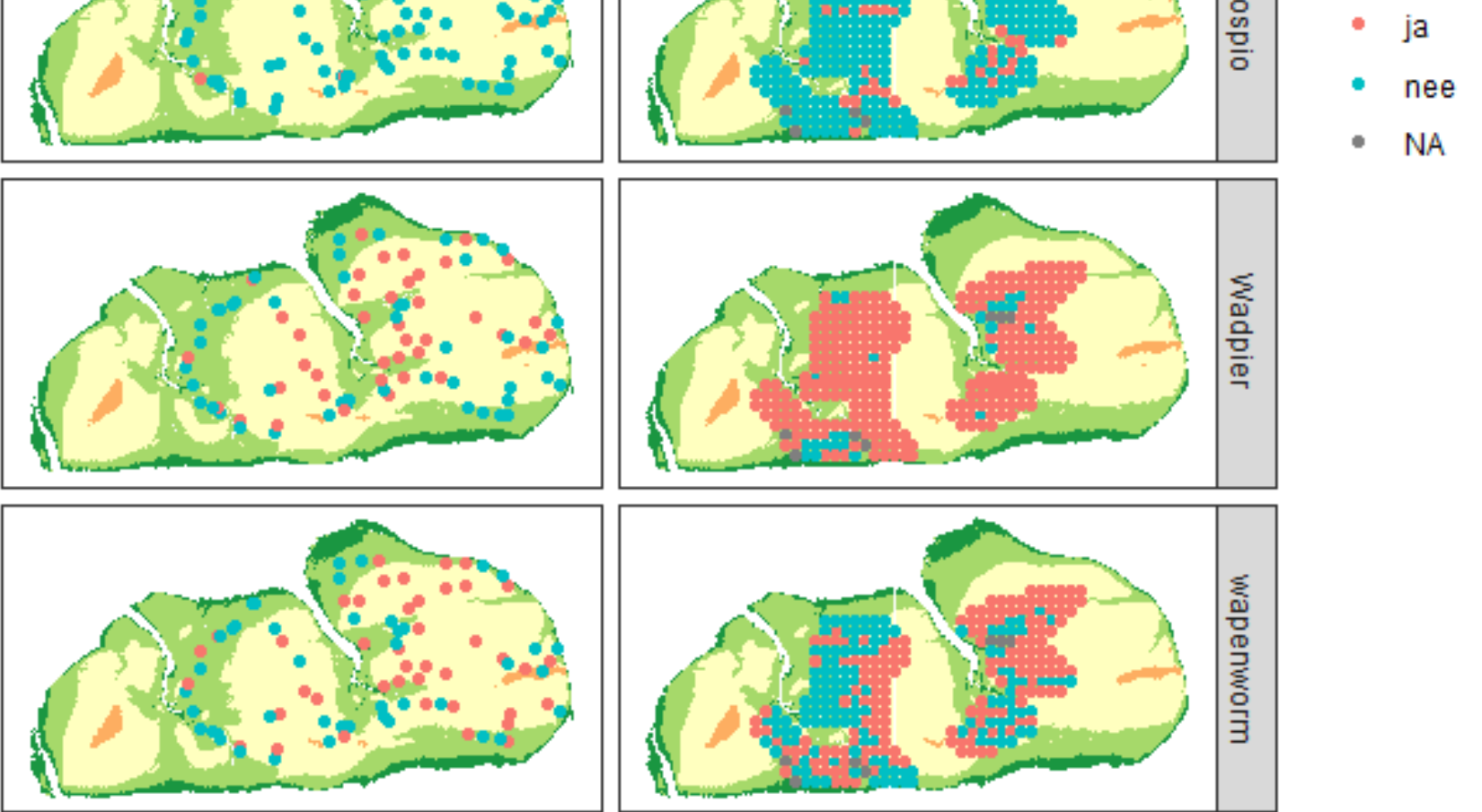

Ion 

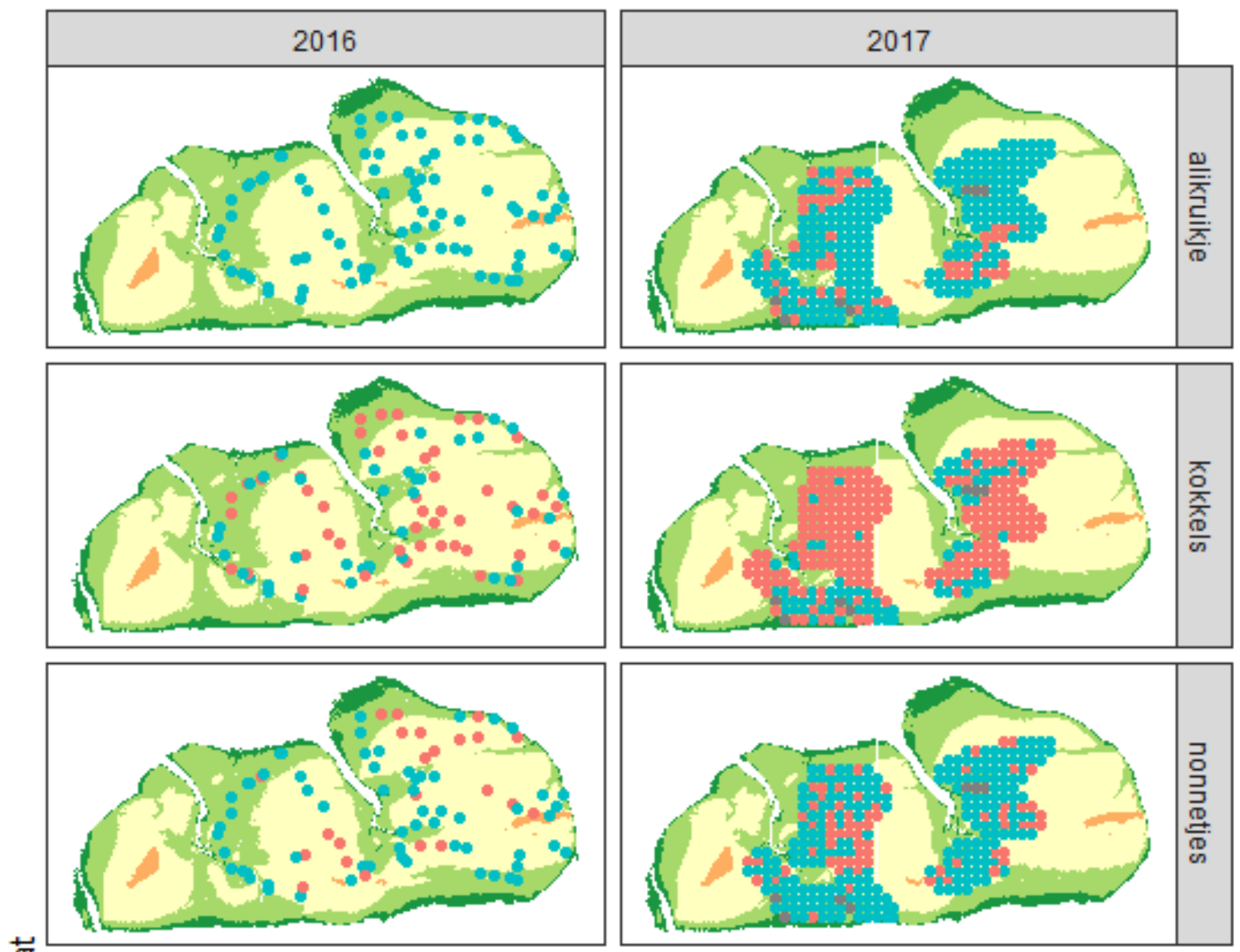

hoogte [m NAP]

范
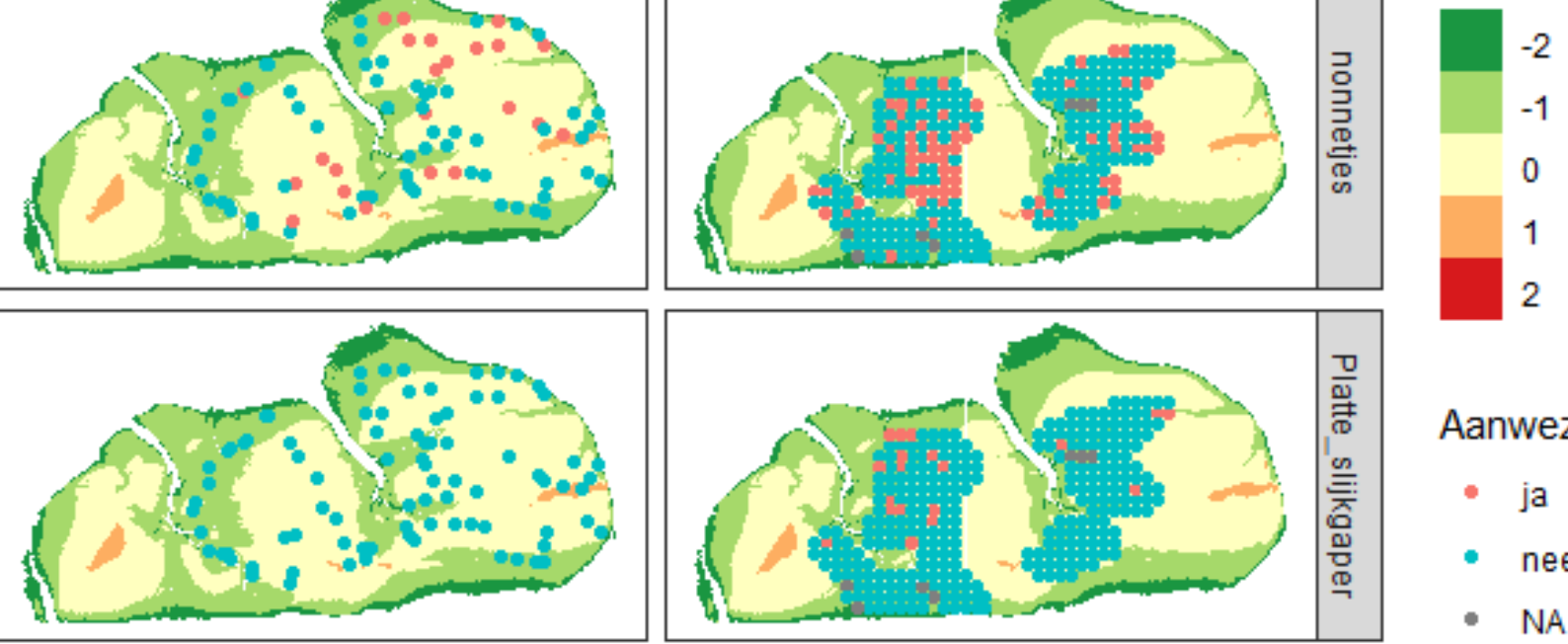

Aanwezig

- ja

- nee

- NA
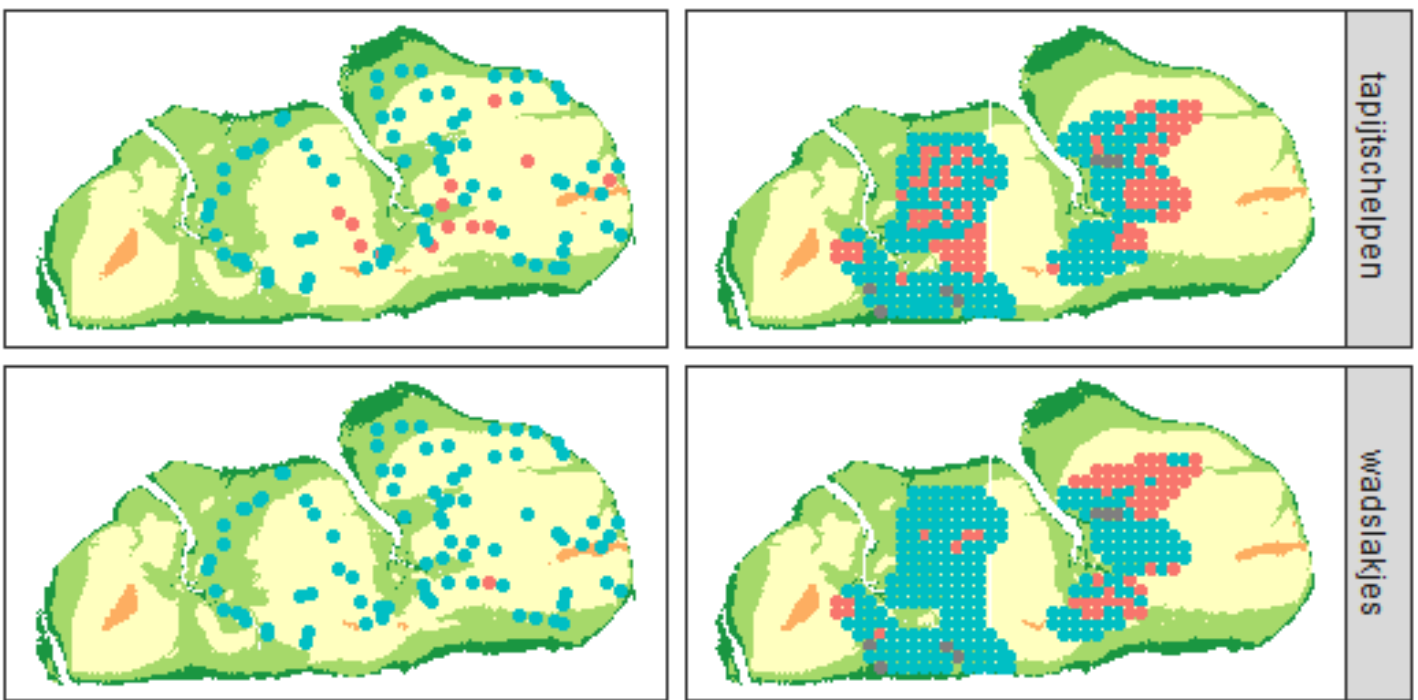

Ion 

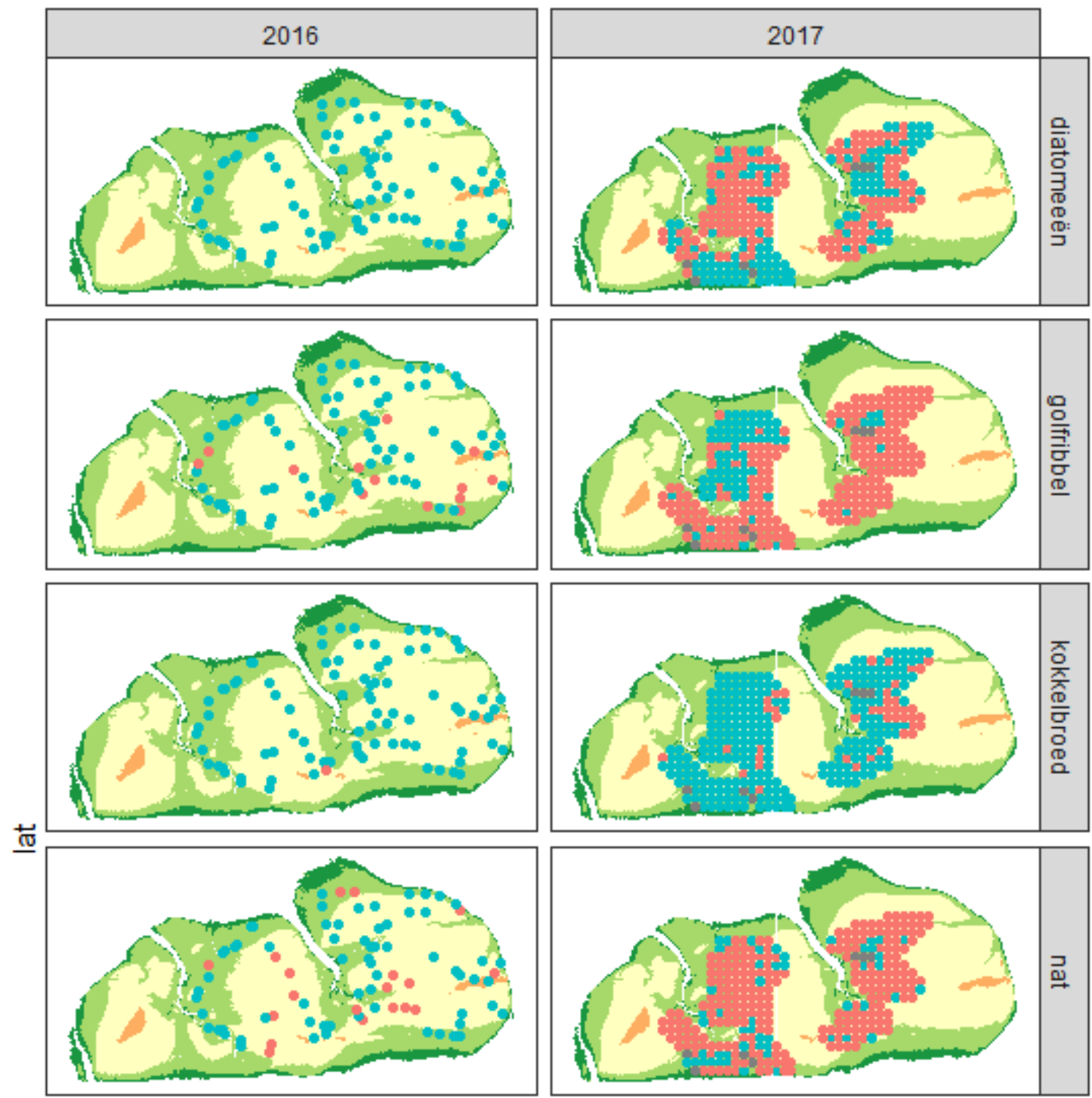

hoogte [m NAP]
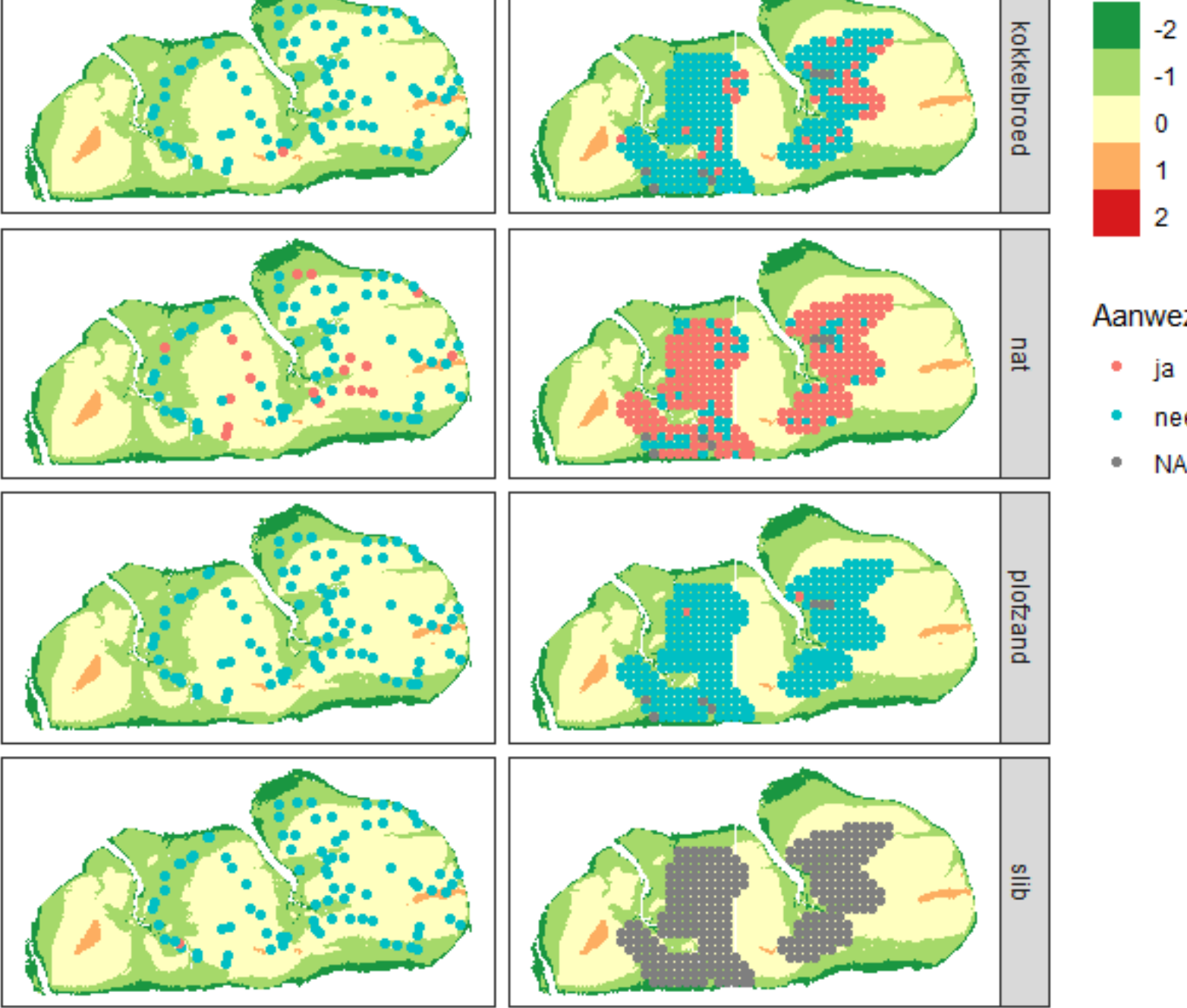

Ion 

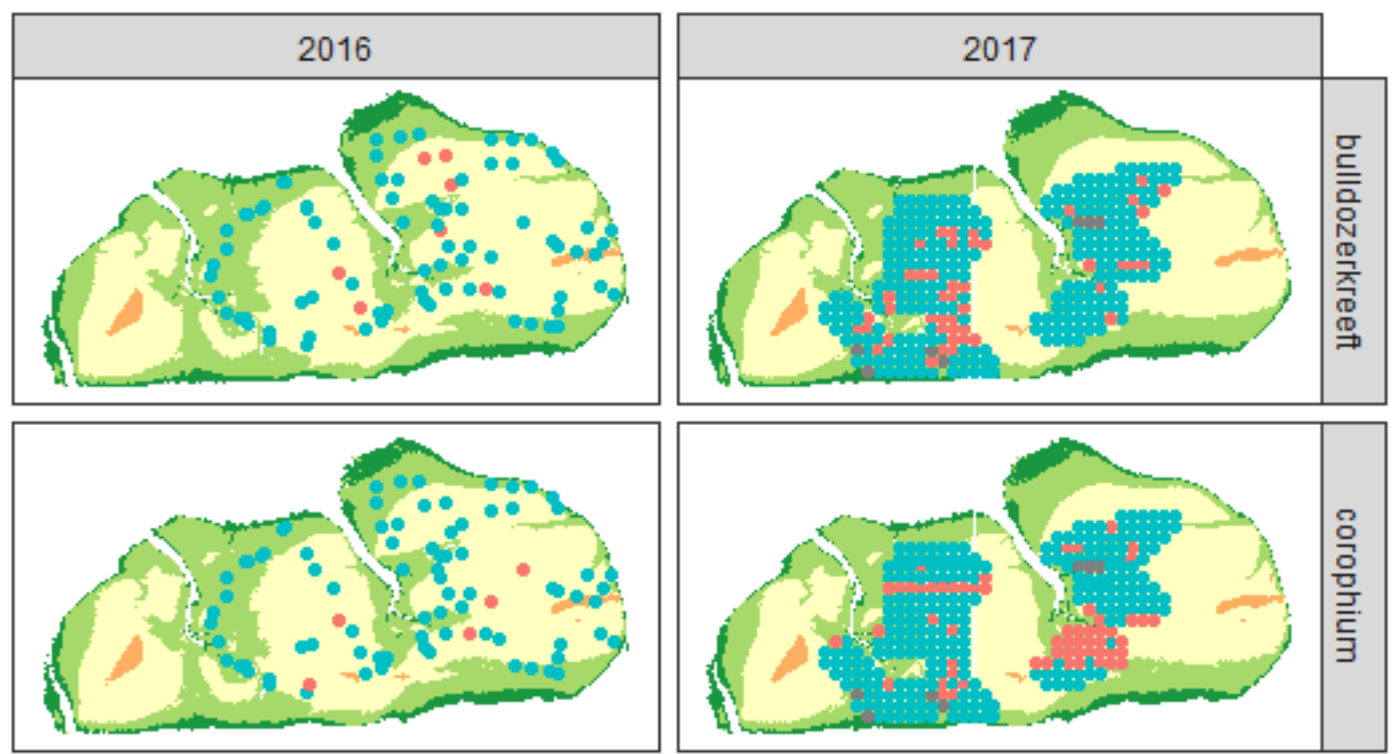

hoogte [m NAP]
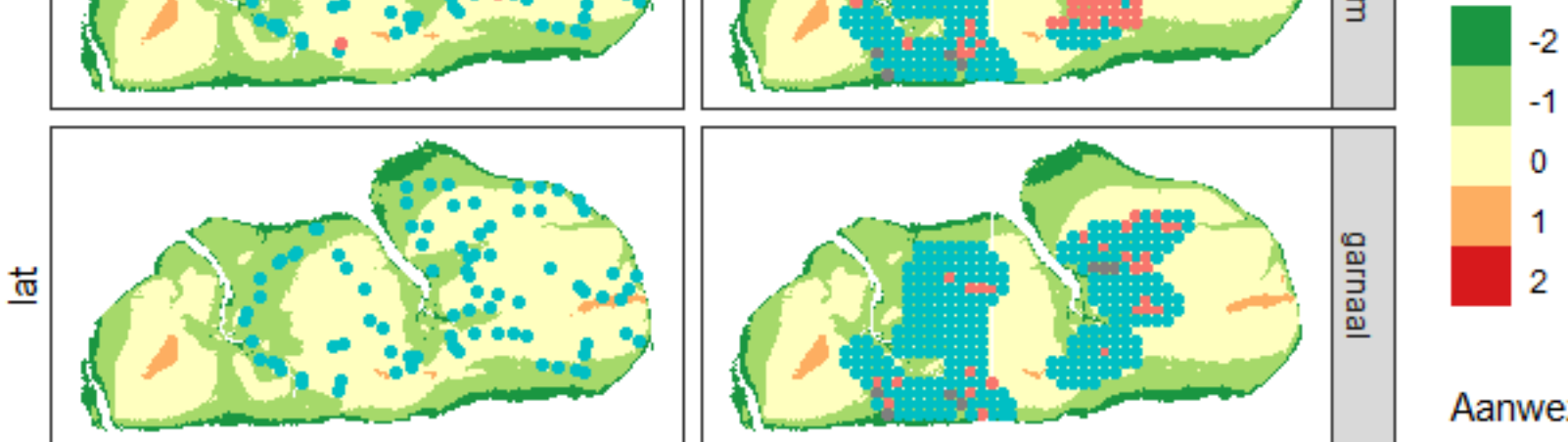

\section{Aanwezig}
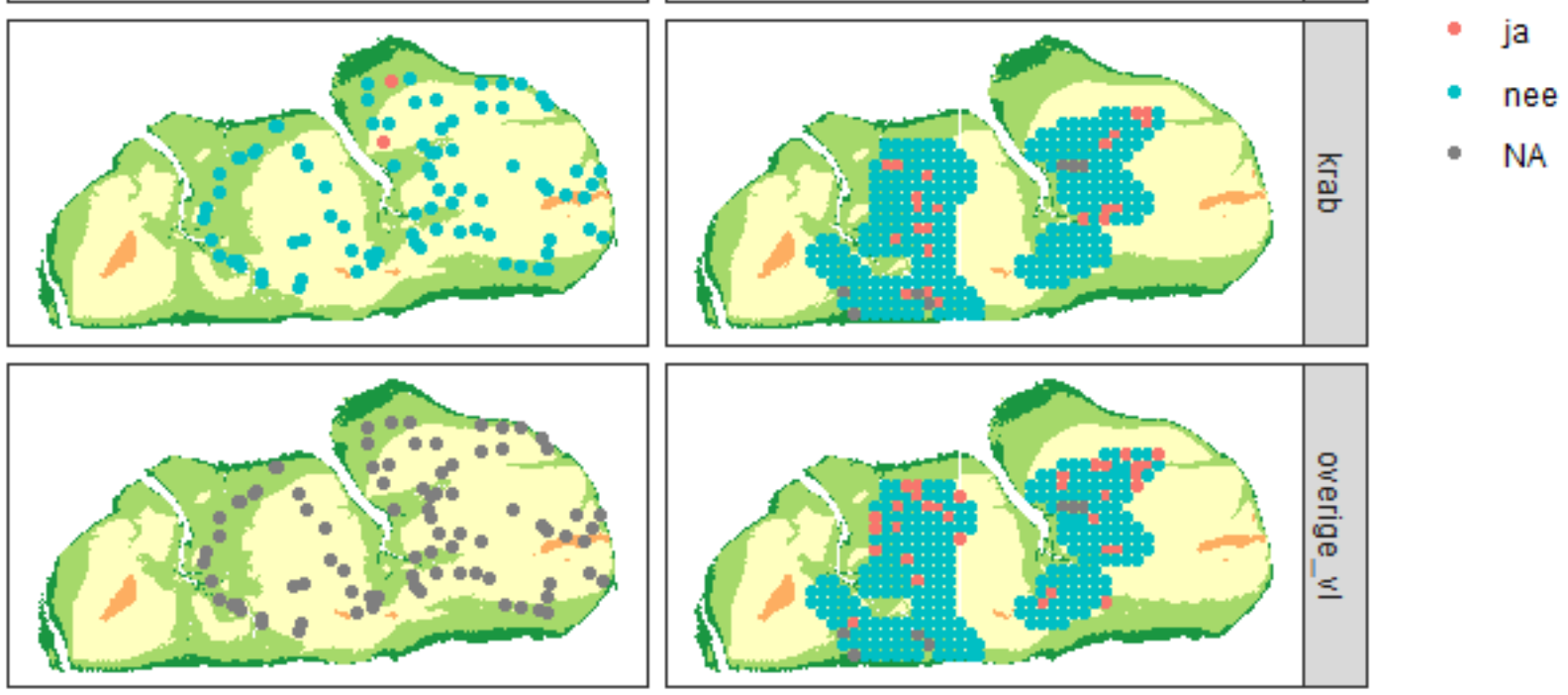

Ion 


\section{Bijlage 8 Aantal en samenstelling vogels over de tijd}

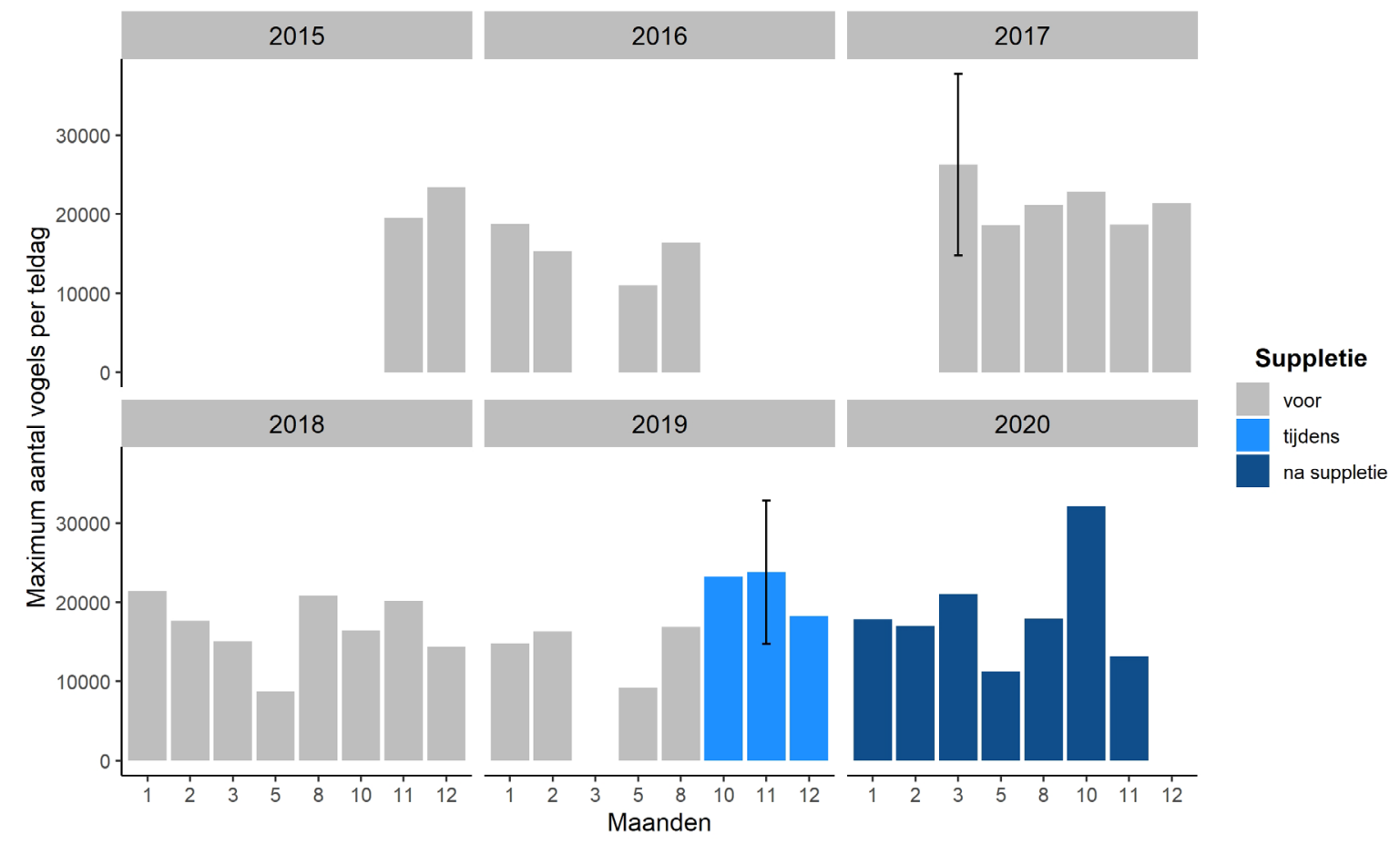

Figuur 10-1 Maximum aantal vogels per teldag over de jaren

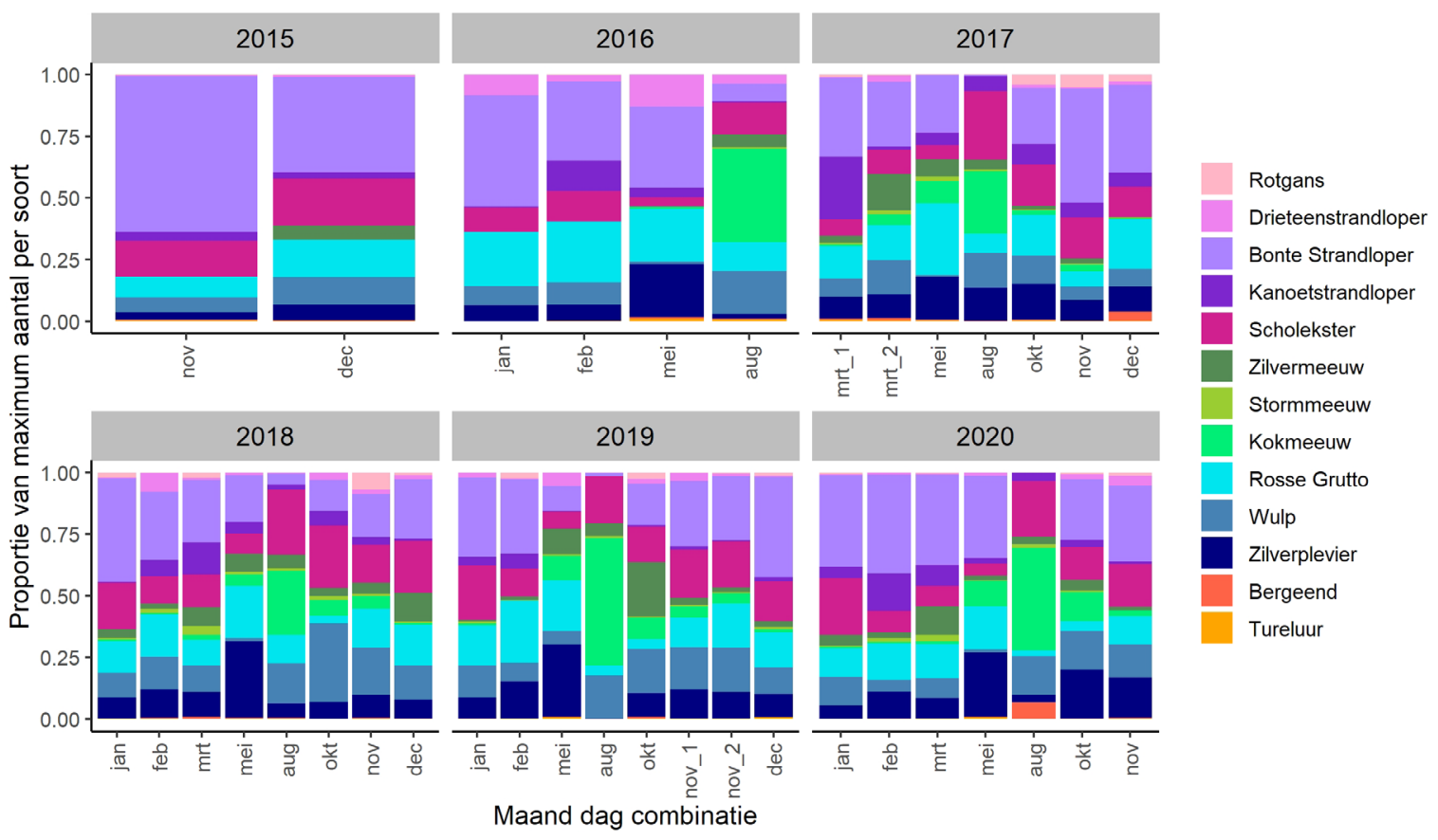

Figuur 10-2. Samenstelling vogels per teldag over de jaren. 


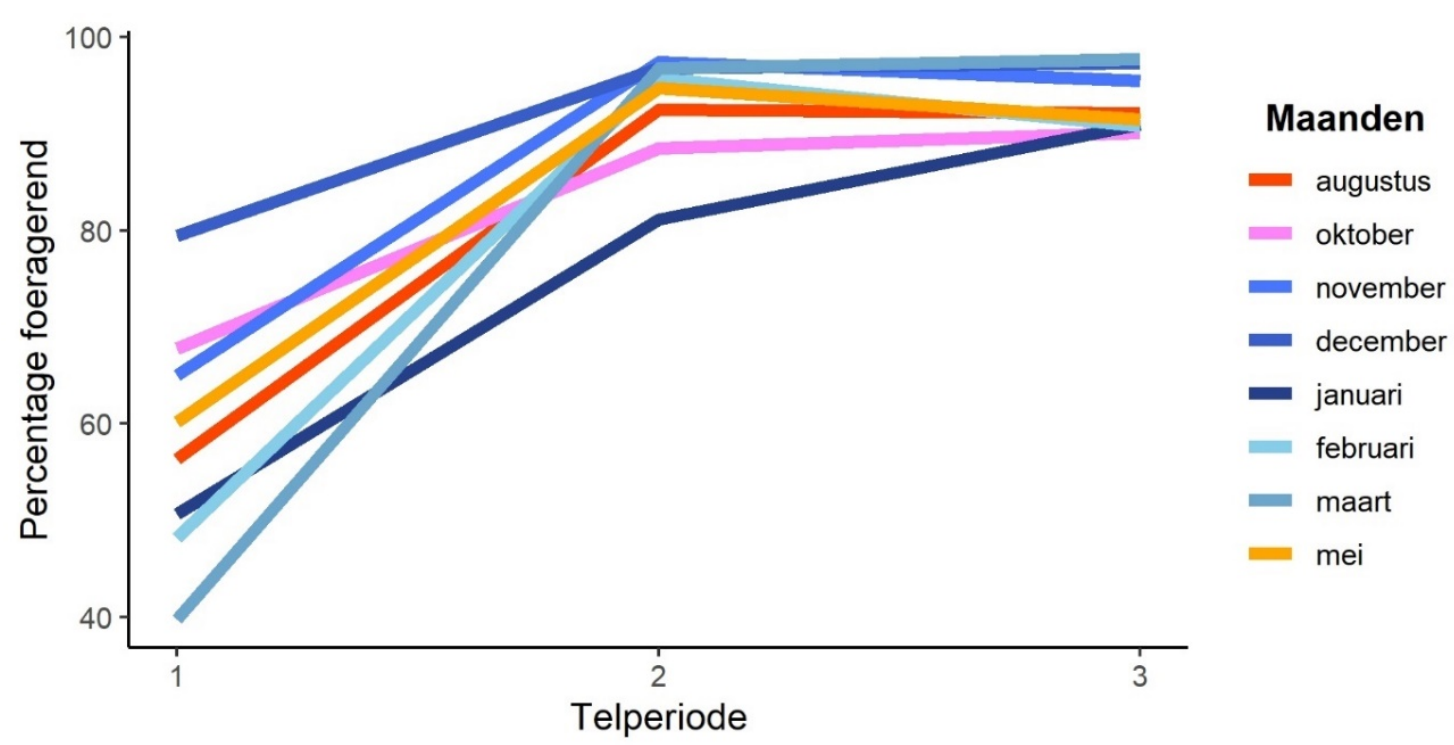

Figuur 10-3. Percentage vogels die foerageren per maand over de drie telperiodes.

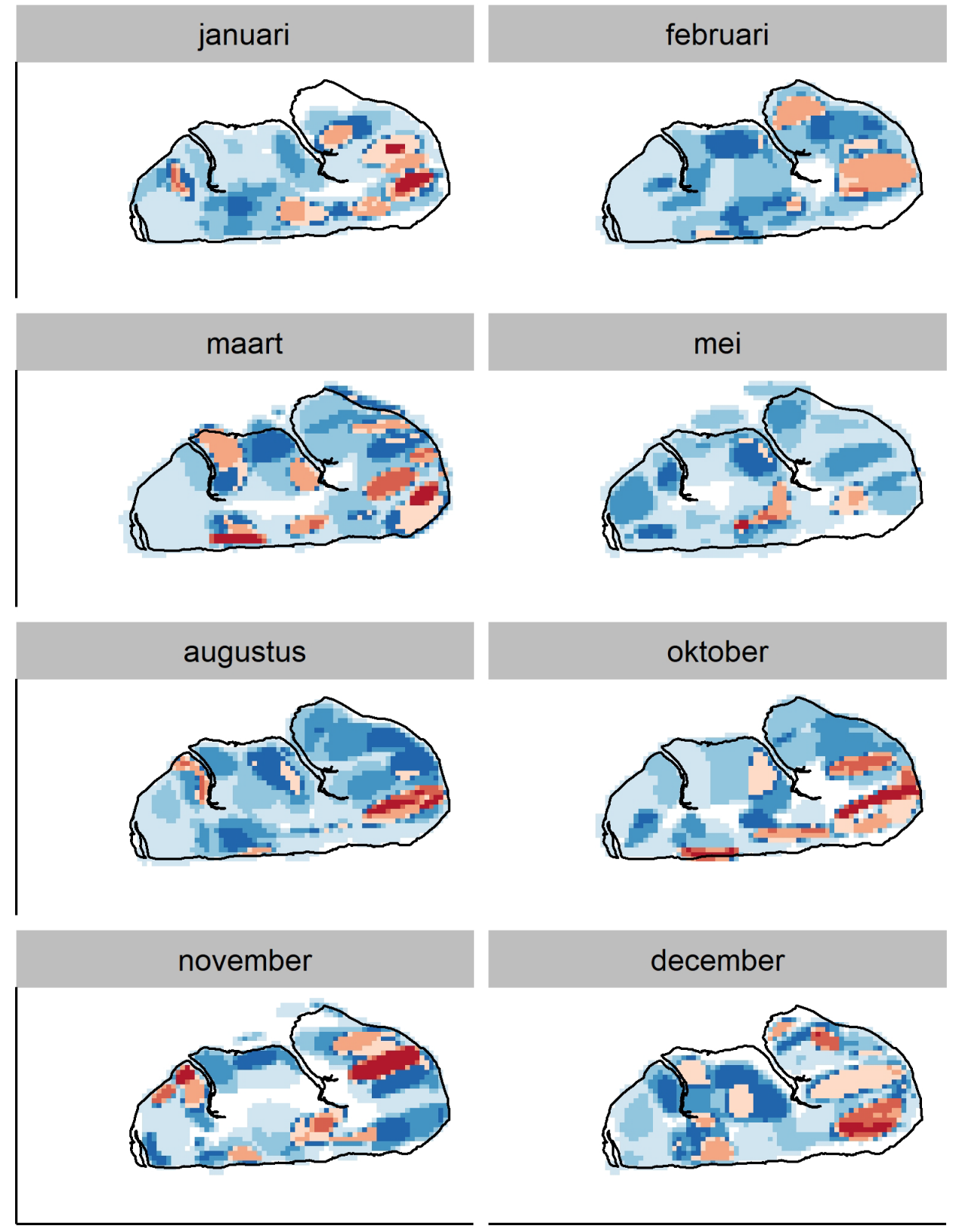

Individuen per $0.1 \mathrm{~km}^{2}$

\begin{tabular}{|l|}
\hline$<5$ \\
\hline $5-10$ \\
$10-15$ \\
$15-20$ \\
\hline $20-25$ \\
\hline $25-37.5$ \\
\hline $37.5-50$ \\
\hline$>50$ \\
\hline
\end{tabular}

Figuur 10-4 Verspreiding gemiddeld aantal vogels in telperiode 2 over de verschillende maanden. 


\section{Bijlage 9 Methode Dataverwerking metingen Middengeultje}

\section{Data opruimen}

Tabel 14 geeft een overzicht van de periodes waarbij er vermoed wordt dat de sensor over een langere periode niet de juiste waarde heeft doorgegeven, en of de data vervolgens is verwijderd in de verdere analyse.

Tabel 14 Perioden per meetmaal waar data ontbreekt of waar vreemde metingen zijn geobserveerd. De laatste kolom geeft aan of deze data is behouden of verwijderd in de verdere analyse.

\begin{tabular}{|c|c|c|c|c|c|}
\hline & Periode & Opmerking & Chl-a & Turb & 更i \\
\hline \multirow[t]{2}{*}{ Meetpaal 1} & 01-03-2019 t/m 20-03-2019 & Data Ontbreekt & $\mathrm{X}$ & & $\mathrm{X}$ \\
\hline & $07-04-2020$ t/m 19-05-2020 & Data Ontbreekt & $\mathrm{X}$ & $\mathrm{X}$ & $\mathrm{x}$ \\
\hline Meetpaal 2 & 03-08-2020 t/m 07-08-2020 & $\begin{array}{l}\text { Negatieve Waarden, } \\
\text { aaneenvolgend }\end{array}$ & $\mathrm{X}$ & & $\mathrm{X}$ \\
\hline \multirow[t]{3}{*}{ Meetpaal 3} & $12-12-2019$ t/m 22-12-2019 & Data Ontbreekt & $\mathrm{X}$ & $\mathrm{X}$ & $\mathrm{x}$ \\
\hline & 01-11-2019 t/m 06-02-2020 & $\begin{array}{l}\text { Meet dagelijks negatieve } \\
\text { waarden, echter is er nog } \\
\text { wel een patroon zichtbaar. }\end{array}$ & $\mathrm{X}$ & & \\
\hline & $20-07-2020$ t/m 31-08-2020 & $\begin{array}{l}\text { Hele hoge turbiditeit } \\
\text { meting, mogelijk is de } \\
\text { sensor geblokkeerd door } \\
\text { iets. Fluctueert heel erg, } \\
\text { maar lijkt geen patroon in } \\
\text { te zitten. }\end{array}$ & & $x$ & $\mathrm{x}$ \\
\hline \multirow[t]{2}{*}{ Meetpaal 4} & $28-02-2019$ t/m 20-03-2019 & $\begin{array}{l}\text { Negatieve waarden chl, } \\
\text { turbiditeit heel hoog } \\
\text { (aaneenvolgend, constant), } \\
\text { na installatie nieuwe } \\
\text { sensor. }\end{array}$ & $\mathrm{x}$ & $x$ & $\mathrm{x}$ \\
\hline & $\begin{array}{l}20-03-2019 \text { t/m 25-04- } \\
2019\end{array}$ & $\begin{array}{l}\text { Opeens hoge waarden voor } \\
\text { chlorofyl, nog wel een } \\
\text { patroon }\end{array}$ & $\mathrm{X}$ & & $\mathrm{X}$ \\
\hline \multirow{2}{*}{$\begin{array}{l}\text { Alle } \\
\text { meetpalen }\end{array}$} & 01-07-2019 t/m 01-09-2019 & Bloei van zeesla & $\mathrm{X}$ & & $\mathrm{X}$ \\
\hline & $01-07-2019$ t/m 01-09-2020 & Bloei van zeesla & $\mathrm{X}$ & & $\mathrm{x}$ \\
\hline
\end{tabular}

\section{Statistische analyse}

Tijdreeks observaties zijn vaak sterk aan elkaar gecorreleerd, dit wil zeggen data een observatie op tijdstip $t$ afhankelijk is van een observatie op tijdstip $t-1$ en $t+1$. Hierdoor is het niet mogelijk om gebruikelijke testen zoals een ANOVA te gebruiken. Een poging is gedaan om een repeated measures ANOVA uit te voeren op de data, echter blijkt de data hier niet bruikbaar voor te zijn. 
Wageningen Marine Research

$\mathrm{T}:+31(0) 317480900$

E: marine-research@wur.nl

www.wur.nl/marine-research

Bezoekers adres:

- Ankerpark 271781 AG Den Helder

- Korringaweg 7, 4401 NT Yerseke

- Haringkade 1, 1976 CP IJmuiden
Wageningen Marine Research levert met kennis, onafhankelijk wetenschappelijk onderzoek en advies een wezenlijke bijdrage aan een duurzamer, zorgvuldiger beheer, gebruik en bescherming van de natuurlijke rijkdommen in zee-, kust- en zoetwatergebieden.

Wageningen Marine Research is onderdeel van Wageningen University \& Research. Wageningen University \& Research is het samenwerkingsverband tussen Wageningen University en Stichting Wageningen Research en heeft als missie: 'To explore the potential of nature to improve the quality of life' 